

\section{Revista Brasileira de Ecoturismo \\ Volume 06, Número 03, agosto/outubro de 2013}

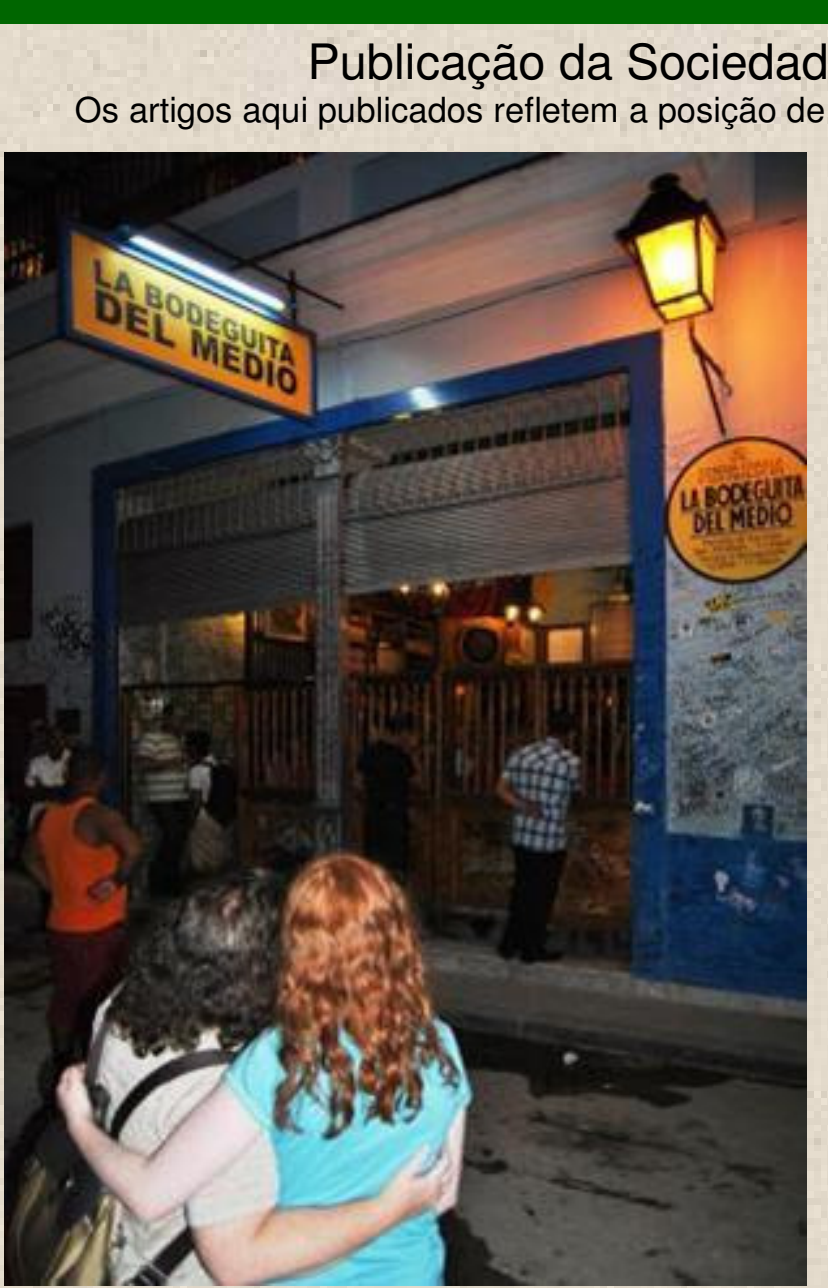

\section{Editor-Chefe}

Prof. Dr. Zysman Neiman

\section{Editores:}

Prof. Dr. Alexandre de Gusmão Pedrini

Profa. Dra. Vivian Castilho da Costa

\section{Editor Executivo}

Prof. Esp. Carlos Eduardo Silva

\section{Editoras de Idiomas \\ Malila Carvalho de Almeida Prado}

\section{Editor de Design (Capa e layout do site) Lucas Neiman}

\section{Fotos}

\section{Zysman Neiman}

\section{Website: www.sbecotur.org.br/rbecotur}

End.: Rua Dona Ana, 138, Vila Mariana, São Paulo, SP - Brasil, CEP 04111-070

Tel.: (11) 99195-7685

E-mail: rbecotur@sbecotur.org.br

\section{Comitê Avaliador:}

Prof. Dr. Adriano Severo Figueiró

Profa. Dra. Alcyane Marinho

Prof. Dr. Alexandre de Gusmão Pedrini

Prof. Dr. Alexandre Panosso Netto

Profa. Dra. Almerinda Antonia Barbosa Fadini

Profa. Dra. Ana María Wegmann Saquel

Prof. Dr. Anderson Pereira Portuguez

Profa Dra. Andréa Rabinovici

Profa. Dra. Beatriz Veroneze Stigliano

Prof. Dr. Bruno Pereira Bedim

Profa. Dra. Camila Gonçalves de Oliveira Rodrigues

Profa. Dra. Célia Maria de Toledo Serrano

Prof. Dr. Davis Gruber Sansolo

Profa. Dra. Denise de Castro Pereira

Prof. Dr. Eduardo Humberto Ditt

Profa. Dra. Elizabete Tamanini

Profa. Dra. Fernanda Sola

Prof. Dr. Ferdinando Filetto

Prof. Dr. Flávio José de Lima Silva

Prof. Dr. Francisco Fransualdo de Azevedo

Prof. Dr. Giovanni de Farias Seabra

Arq. Hector Ceballos-Lascurain

Prof. Dr. Hermann Atila Hrdlicka

Profa. Dra. Heloisa Turini Bruhns

Prof. Dr. Heros Augusto Santos Lobo

Prof. Dr. Ismar Borges de Lima

Prof. Dra. Ivani Ferreira de Faria

Prof. Dr. Jesús Manuel López Bonilla

Profa. Dra. Jasmine Cardoso Moreira

Prof. Dr. João Luiz de Moraes Hoefel

Prof. Dr. José Artur Barroso Fernandes

Prof. Dr. José Manoel Gonçalves Gândara

Prof. Dr. José Martins da Silva Júnior

Profa. Dra. Kerlei Eniele Sonaglio

Profa. Dra. Lilia dos Santos Seabra

Prof. Dr. Lucio Flavo Marini Adorno

Prof. Dr. Luiz Afonso Vaz de Figueiredo

Profa. Dra. Luzia Neide Menezes Teixeira Coriolano

Prof. Dr. Marcos Aurélio Tarlombani da Silveira

Profa. Dra. Maria Cristina Basílio Crispim da Silva

Profa. Dra. Maria Geralda de Almeida

Profa. Dra. Maria Goretti da Costa Tavares

Profa. Dra. Maria Lúcia Ferreira da Costa Lima

Prof. Dr. Mário Jorge Cardoso Coelho Freitas

Profa. Dra. Marlene Huebes Novais

Profa. Dra. Marta de Azevedo Irving

Prof. Dr. Milton Augusto Pasquotto Mariani

Profa. Dra. Nadja Castilho da Costa

Profa. Dra. Odaleia Telles M. Machado Queiroz

Prof. Dr. Paolo Giuntarelli

Prof. Dr. Paulo dos Santos Pires

Prof. Dr. Pedro de Alcântara Bittencourt César

Prof. Dr. Reinaldo Tadeu Boscolo Pacheco

Prof. Dr. Sidnei Raimundo

Profa. Dra. Solange Terezinha de Lima Guimarães

Profa. Dra. Sueli Ângelo Furlan

Prof.a. Dra. Suzana Machado Padua

Profa. Dra. Teresa Cristina de Miranda Mendonça

Profa. Dra. Vanice Santiago Fragoso Selva

Profa. Dra. Vivian Castilho da Costa

Prof. Dr. Zysman Neiman 


\section{ARTIGOS}

Deficiência e equiparidade: um panorama da acessibilidade aos deficientes visuais no Corredor

Cultural de Mossoró (RN).

Eider Elias Duarte, Michele de Sousa

Disability and equality: an overview of the accessibility to the visually impaired in the Corredor

Cultural of Mossoró (RN, Brazil).

Eider Elias Duarte, Michele de Sousa

A segurança como elemento da hospitalidade: a presença das Unidades de Polícia Pacificadora como elemento facilitador do desenvolvimento do turismo nas favelas do Rio de Janeiro (RJ).....

Manoela Carrillo Valduga, Reginaldo Lima de Moura

Security as part of hospitality: the presence of the Pacifying Police Units as facilitator of the development of tourism in the favelas of Rio de Janeiro $(R J)$.....

Manoela Carrillo Valduga, Reginaldo Lima de Moura

Turismo de base comunitária e desenvolvimento socioespacial: um diálogo possível.

Alessandra Silva Lobato

Community-based tourism and socio-spatial development: dialogue possible

Alessandra Silva Lobato

Práticas discursivas e produção de sentidos do "patrimônio": o mito da São Luís (MA), a Atenas

brasileira.

Conceição de Maria Belfort Carvalho

Discursive practices and production of meanings of "heritage": the myth of São Luís (MA), the

Brazilian Athens

Conceição de Maria Belfort Carvalho

As festas de Nossa Senhora da Conceição e a encenação da Paixão de Cristo: os desafios ao Maryvone Moura Gomes, Christian Dennys Monteiro De Oliveira

The Parties of Nossa Senhora da Conceição and the play off Christ Passion: the challenges to immaterial heritage and tourism in Pacatuba city (CE, Brazil)....

Maryvone Moura Gomes, Christian Dennys Monteiro De Oliveira

Vale do Paraíso: a sustentabilidade de uma iniciativa endógena de turismo no espaço rural......

Bianca Pugen, Marcos Daniel Schmidt de Aguiar, Vera Lúcia Boeno de Oliveira

Vale do Paraíso: the sustainability of an endogenous initiative of tourism in rural space.

Bianca Pugen, Marcos Daniel Schmidt de Aguiar, Vera Lúcia Boeno de Oliveira

O lugar Kalunga como lugar turístico: um olhar sobre o turismo rural no Engenho II em

Cavalcante .708

Jorgeanny de Fátima Rodrigues Moreira, Maria Geralda de Almeida

The Kalunga's place of the tourist place: a glimpse into rural tourism in Engenho II

(Cavalcante, GO, Brazil). 
Perspectivas e ações de diferentes atores sociais na gestão e sustentabilidade do turismo em Vargem (SP).

Cristiane Ferraz e Silva Suarez, Nayra de Moraes Gonçalves, João Luiz de Moraes Hoefel

Perspectives and actions of different social actors in the management and sustainability of tourism in Vargem (SP, Brazil)

Cristiane Ferraz e Silva Suarez, Nayra de Moraes Gonçalves, João Luiz de Moraes Hoefel

Ecoturismo: encontros e desencontros na Reserva Extrativista do Cazumbá-Iracema (AC)

Edilaine Albertino de Moraes, Marta de Azevedo Irving

Ecotourism: agreements and disagreements in Extractive ReserveCazumbá-Iracema (AC, Brazil) .....738

Edilaine Albertino de Moraes, Marta de Azevedo Irving

Empreendedorismo sustentável em regiões turísticas de Goiás.

Thaynara Santiago Pereira, Cândido Vieira Borges Junior

Sustainable entrepreneurship in tourist regions of Goiás (Brazil).

Thaynara Santiago Pereira, Cândido Vieira Borges Junior

Contribuições da Educação Ambiental para o turismo em Bragança (PA) (Amazônia Atlântica): uma perspectiva participativa.

Glauce Vitor da Silva, Altem Nascimento Pontes, Alexandre Macedo Pereira, Aline Maria Meiguins de Lima

Contributions of Environmental Education for tourism in Bragança (PA, Brazil) (Amazon

rainforest): a participatory approach.

Glauce Vitor da Silva, Altem Nascimento Pontes, Alexandre Macedo Pereira, Aline Maria Meiguins de Lima

Estudando o centro histórico de Natal $(\mathrm{RN})$ e suas possibilidades para o turismo 800

Patrícia Daliany Araújo do Amaral, Isabella Ludimilla Barbosa do Nascimento, Fábio Henrique da Silva

Studying the historical center of Natal $(R N)$ and its possibilities for tourism.

Patrícia Daliany Araújo do Amaral, Isabella Ludimilla Barbosa do Nascimento, Fábio Henrique da Silva 


\section{APRESENTAÇÃO}

A REVISTA BRASILEIRA DE ECOTURISMO (RBEcotur) é uma publicação eletrônica trimestral produzida pela Sociedade Brasileira de Ecoturismo (SBEcotur), sendo expressão do esforço dos profissionais nela envolvidos: editores e outros colaboradores. Criada em 2008, seus volumes são editados exclusivamente na formatação eletrônica on line (SEER).

MISSÃO: Publicar artigos inéditos de caráter científico com o objetivo de atender diferentes profissionais diante dos vários contextos de estudos e pesquisas em Ecoturismo e atividades afins, contribuindo para a difusão, diálogo e intercâmbio de conhecimentos teóricos ou aplicados, bem como para a formação de redes. Propõem-se a promover um amplo debate entre o poder público e privado, as operadoras, as agências, ONGs e instituições de ensino e pesquisa, principalmente no que tange a aplicação do planejamento e manejo do Ecoturismo voltado a práticas de mínimo impacto.

A transferência e troca desses conhecimentos são de suma importância para que a análise e a prevenção dos impactos do Ecoturismo e atividades afins se constituam em ferramenta imprescindível para dar subsídio à manutenção das práticas de preservação e ao planejamento estratégico de atividades de lazer, interpretativas da natureza e de Educação Ambiental, ligadas à conservação dos recursos naturais.

São os seguintes os eixos temáticos desta revista:

- Eixo 1 - Ecoturismo e Educação Ambiental

- Eixo 2 - Planejamento e Gestão do Ecoturismo

- Eixo 3 - Manejo e Conservação dos recursos naturais através do Turismo Sustentável

- Eixo 4 - Ensino, Pesquisa e Extensão em Ecoturismo

- Eixo 5 - Ecoturismo de Base Comunitária

O Ecoturismo é uma prática que precisa ser mais bem estudada e compreendida pois, apesar de já ser praticado há mais de cem anos (desde a criação dos primeiros parques nacionais no múndo: Yellowstone e Yosemite), só nos últimos anos do século XX se configurou como um fenômeno crescente e economicamente significativo.

Embora os seus princípios e diretrizes estejam claramente estabelecidos e pareçam conceitualmente compreendidos pelos profissionais da área, na prática, o Ecoturismo carece ainda de uma visão estratégica, que promova seu desenvolvimento em nível nacional. Esta afirmação é especialmente verdadeira quando são analisados os projetos de desenvolvimento em implementação no Brasil e as dificuldades no planejamento e obtenção de resultados referentes aos compromissos com a Sustentabilidade.

Assim, convidamos todos os pesquisadores e produtores de conhecimento em Ecoturismo e áreas afins a somar seus esforços aos nossos, divulgando suas ideias nas edições da REVISTA BRASILEIRA DE ECOTURISMO.

Prof. Dr. Zysman Neiman

Prof. Dr. Alexandre de Gusmão Pedrini

Profa. Dra. Vivian Castilho da Costa

\section{Editores da RBEcotur}




\section{EDITORIAL}

Prezados leitores e colaboradores.

Esta edição da RBEcotur apresenta mais alguns artigos completos de trabaIhos apresentados no XII Encontro Nacional de Turismo com Base Local (ENTBL), e trás novas contribuições inéditas de outros autores. A publicação dos artigos do ENTBL deverá prosseguir ainda mais por uma edição deste volume 6 da RBEcotur, pois há ainda alguns outros manuscritos em fase final de ajustes para publicação, após sugestões dos coordenadores dos GTs onde os mesmos foram apresentados.

Por esse motivo, bem como a grande quantidade de artigos que vêm sendo submetidos a nossa Revista, graças ao reconhecimento que a mesma vem obtendo junto ao mundo acadêmico e aos órgão avaliadores, decidimos, desde a edição passada, por ampliar a periodicidade das publicações, que agora serão trimestrais. A Revista passa a ter edições em fevereiro (excepcionalmente em janeiro em 2013), maio, agosto e novembro já em 2013.

Nesta edição apresentamos 12 artigos inéditos:

- Eider Elias Duarte e Michele de Sousa discutem a existência de acessibilidade para os deficientes visuais no Corredor Cultural de Mossoró nos aspectos arquitetônico, educacional, ergométrico e em relação às atitudes da sociedade.

- Manoela Carrillo Valduga e Reginaldo Lima de Moura apresentam a temática do desenvolvimento do Turismo em Favelas a partir da análise das relações de hospitalidade configuradas após a implementação das Unidades de Polícia Pacificadora (UPPs) nas comunidades Dona Marta, Chapéu-Mangueira, PavãoPavãozinho-Cantagalo e Tabajaras - Cabritos, todas localizadas na cidade do Rio de Janeiro.

- Alessandra Silva Lobato discute se é possível a existência de um diálogo entre Turismo de Base Comunitária e Desenvolvimento Socioespacial, no sentido de utilizar estes conceitos na elaboração de projetos voltados ao desenvolvimento do turismo em áreas de comunidades tradicionais.

- Conceição de Maria Belfort Carvalho problematiza a constituição da identidade de São Luís (MA) em torno da figura da Atenas Brasileira, analisando o conceito de patrimônio dela decorrente e a construção do espaço turístico. 
- Maryvone Moura Gomes e Christian Dennys Monteiro de Oliveira discutem o lugar a partir das dinâmicas geográficas vivenciadas entre as festas de Nossa Senhora da Conceição e da Encenação da Paixão de Cristo em Pacatuba (CE), através da analise da representação simbólica que as festas dão ao lugar, buscando compreender de que maneira a festa espetacular desafia a cidade enquanto bem patrimonial e turístico.

- Bianca Pugen, Marcos Daniel Schmidt de Aguiar e Vera Lúcia Boeno de Oliveira realizaram uma pesquisa para entender e analisar alguns aspectos relativos à sustentabilidade das atividades de turismo rural no roteiro denominado Vale do Paraíso, no município de Três Cachoeiras, Litoral Norte do Rio Grande do Sul.

- Jorgeanny de Fátima Rodrigues Moreira e Maria Geralda de Almeida apresentam algumas reflexões e discussões acerca do desenvolvimento do turismo cultural e rural no Engenho II, uma comunidade constituída por remanescentes de quilombolas localizada no município de Cavalcante, nordeste de Goiás.

- Cristiane Ferraz e Silva Suarez, Nayra de Moraes Gonçalves e João Luiz de Moraes Hoeffel identificaram perspectivas e ações de diferentes atores sociais na gestão e sustentabilidade do turismo no município da Vargem (SP), bem como as estratégias e ações existentes para o turismo sustentável e a conservação ambiental.

- Edilaine Albertino de Moraes e Marta de Azevedo Irving analisam como os moradores do Núcleo do Cazumbá (Reserva Extrativista do Cazumbá-Iracema - AC) interpretam o ecoturismo, em seu panorama atual e futuro.

- Thaynara Santiago e Cândido Borges investigam como os empreendedores que exploram o nicho da sustentabilidade realizam as principais atividades do processo de criação de empresas e identificar quais são os principais desafios desse processo em duas regiões turísticas de Goiás - Pirenópolis e Chapada dos Veadeiros.

- Glauce Vitor da Silva, Altem Nascimento Pontes, Alexandre Macedo Pereira e Aline Maria Meiguins de Lima avaliam o município de Bragança (polo turístico Amazônia Atlântica, litoral nordeste do Pará), que apresenta como principal a- 
trativo para a atividade turística o seu patrimônio cultural e paisagístico, discutindo a relação entre as práticas de turismo desenvolvidas no município e a demanda por ações de educação ambiental como um instrumento de construção de uma gestão participativa do turismo local

- Patrícia Daliany Araújo do Amaral, Isabella Ludimilla Barbosa do Nascimento e Fábio Henrique da Silva Gomes analisam o potencial do Centro Histórico de Natal (RN) para o turismo, compreendendo assim a importância dos valores desse espaço para o fortalecimento de um segmento turístico pouco desenvolvido na cidade.

Aproveitamos para anunciar que continuam abertas as inscrições para o Congresso Nacional de Ecoturismo (CONECOTUR) e para o Encontro Interdisciplinar de Ecoturismo em Unidades de Conservação (EcoUC), em suas edições IX e V, respectivamente, que acontecerão na cidade de Rio Branco (AC). Mais uma vez, será responsabilidade da Sociedade Brasileira de Ecoturismo (SBEcotur) a Coordenação Científica dos eventos, em parceria com a Secretaria de Turismo e Lazer (SETUL) do Estado do Acre.

A todos, uma boa leitura!

Zysman Neiman

Editor Chefe

Nota dos Editores:

O Buriti (Mauritia flexuosa), presente no logotipo da RBEcotur, é uma homenagem à Pindorama, a "Terra das Palmeiras", com suas paisagens de grande potencial para o ecoturismo, bem como às suas veredas, que compõem alguns dos mais expressivos e belos conjuntos cênicos de nosso país. A cada número da Revista, uma árvore brasileira será evocada. Neste número a homenageada é o Macuco D’Água (Henriquezia nitida), árvore que ocorre no arquipélago das Anavilhanas, amazônia brasileira, ambiente que está ilustrado na capa desta edição, rico em Igapós, como o que aparece na imagem que abre a seção de artigos, registrada de região de Novo Airão (AM).

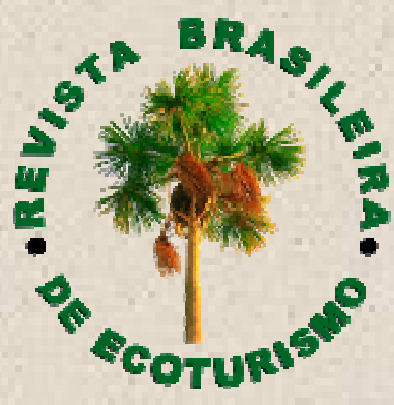




\section{SEÇÃO}

ARTIGOS 
És tão doce, beleza, se te chamasses Teresa, eu teria certeza, meu bem. Mas não tenho certeza de nada, ó desgraça, ó ruína, ó Tupá! Tu sabias que em ti tem taiti, linda ilha do amor e do adeus? tem mandinga, tem mascate, pão-de-açúcar com café, tem chimborazo, kamtchaka, tabor, popocatepel? tem juras, tem jetaturas e até danúbios azuis, tem igapós, jamundás, içás, tapajós, purus! - tens, tens, tens, ah se tens! .

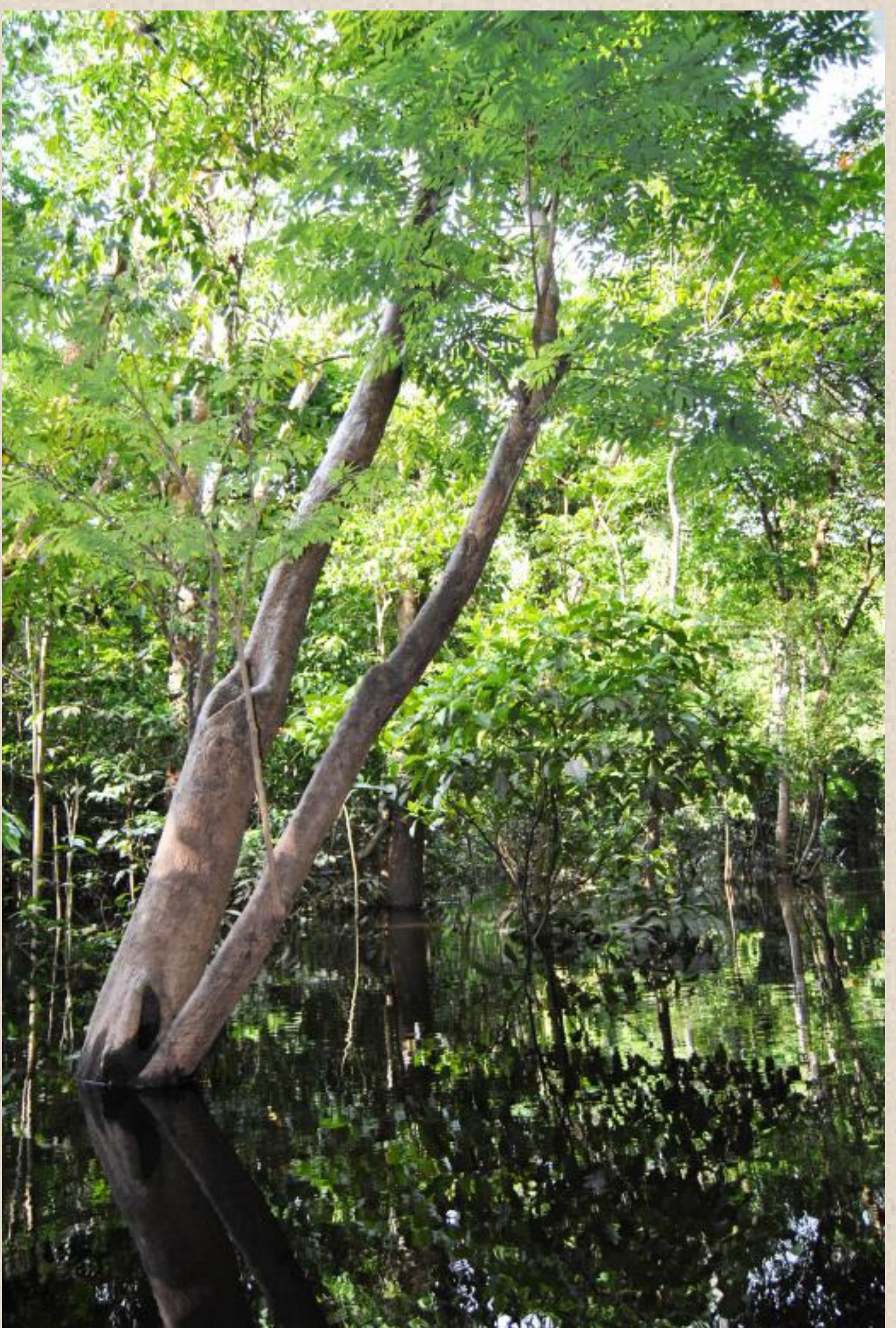

Vinicius de Moraes 
Duarte, E.E.; Sousa, M. Deficiência e equiparidade: um panorama da acessibilidade aos deficientes visuais no Corredor Cultural de Mossoró (RN). Revista Brasileira de Ecoturismo, São Paulo, v.6, n.3, ago/out-2013, pp.612-629.

\title{
Deficiência e equiparidade: um panorama da acessibilidade aos deficientes visuais no Corredor Cultural de Mossoró (RN)
}

\author{
Disability and equality: an overview of the accessibility to the visually impaired \\ in the Corredor Cultural of Mossoró (RN, Brazil)
}

\section{Eider Elias Duarte, Michele de Sousa}

\begin{abstract}
RESUMO
O objetivo da presente pesquisa foi verificar a existência de acessibilidade para os deficientes visuais no Corredor Cultural de Mossoró em seus diversos aspectos, sejam eles: arquitetônico, educacional, ergométrico ou em relação às atitudes da sociedade, procurando identificar os benefícios proporcionados a esse público por meio do lazer com a construção desse espaço. A metodologia utilizada consistiu em algumas visitas para a observação dos espaços que foram estudados na pesquisa: o Teatro Dix -Huit Rosado; Memorial da Resistência; Praça da Convivência e a Praça de Esportes, sempre com o foco na acessibilidade dos deficientes visuais a esses espaços. Informalmente foi entrevistado um vigilante que prestava serviço no Memorial da Resistência no momento da visita, o que também contribuiu para a pesquisa. A escolha dos ambientes a serem estudados do Corredor Cultural de Mossoró devese a observação que nesses espaços as possibilidades para exercício do lazer são mais evidentes e, como o turismo se utiliza dessa ferramenta como forma de agregar valor ao atrativo turístico, torna-se relevante à escolha desses espaços para a pesquisa. Este estudo observou a existência de banheiros adaptados e corrimão para deficientes, além de rampas e pisos táteis que dão acessibilidade aos deficientes visuais, porém com restrições, pois algumas omitem nessas mesmas construções informações necessárias para a independência dos deficientes visuais, afora isso deve também ater-se a formação de guias intérpretes nesses espaços, que é algo necessário e assegurado em lei, o que caracteriza que estes espaços não são totalmente acessíveis, em conformidade com a "Lei da acessibilidade" e a ABNT NBR 9050:2004 e, por conseguinte, não são ainda espaços que permitem a autonomia e a equiparidade entre todos.
\end{abstract}

PALAVRAS-CHAVE: Deficiência; Acessibilidade; Corredor Cultural; Mossoró.

\section{ABSTRACT}

The aim of this study was verifying the existence of accessibility conditions for the visually impaired people in the Corredor Cultural of Mossoró in its various aspects, there are: architectural, educational, ergometric or in relation to society's actions, seeking to identify the benefits to the public through leisure with the construction of this space. The methodology consisted making few visits to observe the spaces that have been studied in the research: the Theatre Dix-Huit Rosado; Memorial da Resistência of Mossoró; Praça da Convivência and Praça de Esportes, always focusing on the accessibility of the visually impaired to such spaces. A guard who worked in Memorial da Resistência at the time of the visit has been informally interviewed, which also contributed to the research. The choice of places to be studied in Corredor Cultural of Mossoró considered the observation that in these spaces the exercise of leisure possibilities are more obvious, and, as tourism uses this tool as a way to add value to the tourist attraction, becomes relevant to the choice of these spaces for research. This study noted the existence of adapted toilets and handrails for persons with disabilities, as well as ramps and tactile flooring that give accessibility to visually impaired people, however with restrictions because some information required for the independence of the visually impaired are omitted in those buildings, moreover it's important to pay attention to having interpreters guides in these spaces, which is necessary and assured by law which indicate that these spaces are not fully accessible, and aren't in accordance with the "law of accessibility" and ABNT NBR 9050:2004 and consequently they still haven't been spaces that allow autonomy and equality among all.

KEYWORDS: Disability; Accessibility; Corredor Cultural; Mossoró. 


\section{Introdução}

Os espaços são construções humanas mutáveis, mudam de acordo com as condições políticas, econômicas, culturais e sociais dos diferentes lugares. Em Mossoró, segunda maior população do estado do Rio Grande do Norte, esta lógica de mudança está presente na estratégia de intervenção e produção do espaço. Ademais, a cidade é marcada por sua dinâmica econômica, a qual tem por base a atividade salineira, petrolífera, agronegócio, além das expressivas atividades comerciais e de serviços que polariza na região do oeste potiguar.

Esta dinâmica tem propiciado a expansão de sua infraestrutura, bem como novos comércios, além de equipamentos de lazer associados à promoção da cultura local, como o "Corredor Cultural de Mossoró".

Este trabalho objetiva verificar a existência de acessibilidade para os deficientes visuais no Corredor Cultural de Mossoró em seus diversos aspectos, sejam eles: arquitetônico, educacional, ergométrico ou em relação às atitudes da sociedade, procurando identificar os benefícios proporcionados a esse público por meio do lazer com a construção desse espaço, levando em consideração a relevância da temática da acessibilidade na atualidade e da inserção dos deficientes na sociedade de uma forma geral, seja na esfera social, profissional e, também, no acesso ao lazer, que é um fator igualmente relevante nas discussões das ciências sociais, pelo seu caráter, que contribui para o desenvolvimento pessoal e social do ser humano.

\section{Deficiência: conceitos e conquistas}

Para conhecer e compreender a dimensão que a deficiência abrange, é preciso apreender e analisar todas as suas nuanças, não somente aquelas onde as deficiências são visíveis, como deformações ou problemas de locomoção, mas também uma análise de como a sociedade trata essas pessoas, a manifestação de preconceitos que geram compaixão e desprezo.

Quando se fala sobre o termo "portador de necessidade especial", de imediato vêm à memória aquelas pessoas que tenham algum problema "visível", deficiências físicas ou visuais. No entanto, será que apenas essas pessoas com problemas visíveis são os únicos portadores de necessidades especiais? O que dizer de uma pessoa que em decorrência de um acidente tenha sua mobilidade prejudicada por algum tempo? Ou então, o que pensar da mobilidade de uma gestante?

Observa-se que os padrões e modelos de normalidade que a sociedade estabeleceu, além de serem entraves para o relacionamento entre deficientes e sociedade, estão repletos de estereótipos, esquecendo que qualquer um é candidato potencial à deficiência, pois ela não está relacionada apenas a fatores congênitos, como nascimento ou genética, mas também a acidentes ocasionais, como os domiciliares ou automobilísticos.

Segundo Brasil (2006), a deficiência atinge entre 7\% e 10\% da população mun- 
dial, no entanto, mesmo diante desse número expressivo, observam-se desconhecimentos por parte da sociedade, no que diz respeito ao significado das deficiências em si e das expressões que são utilizadas para sua compreensão, tais como: portadores de necessidades especiais, mobilidade, acessibilidade, inclusão, tolerância e, principalmente, deficiência.

A definição encontrada em Fonte e Landi (1997, apud SILVA; GONÇALVES, 2006, p.12) afirma que:

O portador de necessidades especiais é a pessoa 'que apresenta significativas diferenças físicas, sensoriais ou intelectuais, decorrentes de fatores inatos ou adquiridos, de caráter temporário ou permanente, e que acarretam dificuldades em sua interação com o meio físico e social'.

Quando a definição refere-se a caráter permanente ou temporário, fica claro que o termo "portador de necessidades especiais" abrange uma parcela da sociedade bem maior do que o imaginado, podendo-se incluir os idosos, obesos e gestantes, entre outros que possam ter sua mobilidade reduzida por algum motivo ou tempo.

Destarte, o processo de inclusão é um fator importante a ser considerado na atualidade, já que somente em nosso país existem cerca de 24,5 milhões de pessoas deficientes (BRASIL, 2009). Para compreender melhor este termo, esclarece-se que deficiente é a "pessoa que possui limitação ou incapacidade para o desempenho de algum tipo de atividade" (BRASIL, 2006, p.14).

Essa é uma definição geral, entretanto, observa-se que existem diversas tipologias para as deficiências, como a física, intelectual, auditiva, múltiplas e visuais, sendo necessária para todas elas uma melhor compreensão, para que essa parcela da sociedade passe a fazer parte do processo de socialização.

Ainda segundo Brasil (2009), dos 14,5\% da população brasileira que é deficiente, $5 \%$ é de deficientes visuais, com diferentes graus, como cegueira total ou parcial. Esse número expressivo da sociedade serve de instrumento para justificar o objetivo deste estudo, que é verificar a acessibilidade dos deficientes visuais aos equipamentos de lazer no Corredor Cultural de Mossoró, para tanto se faz necessário conhecer a deficiência visual como um todo, com os conceitos e peculiaridades pertinentes a mesma, que Brasil (2009, p.27) define como:

Deficiência visual é a cegueira, na qual a acuidade visual é igual ou menor que 0,05 no melhor olho, com a melhor correção óptica; a baixa visão, que significa acuidade visual entre 0,3 e 0,05 no melhor olho, com a melhor correção óptica; os casos nos quais a somatória da medida do campo visual em ambos os olhos forem iguais ou menores que $60^{\circ}$; ou a ocorrência simultânea de quaisquer das condições anteriores. 
Essa parcela da sociedade que possui acessibilidade reduzida por seus problemas visuais, necessita que os tratados, convenções, normas e leis ofereçam dispositivos para facilitar ou amenizar um pouco os problemas a que essas pessoas estão sujeitas, podendo servir de ferramenta para colocar em prática a equiparidade entre os indivíduos considerados normais e os deficientes, amenizando as diferenças que se encontram em evidência na sociedade.

\section{Luta pela equiparidade}

Historicamente, o recurso utilizado pelas famílias para lidar com a deficiência, mesmo que com intuito de proteção, era em sua maioria a segregação, o isolamento dentro de suas residências ou em hospitais, assim esses deficientes eram privados da vivência em sociedade. Segundo Ross (1998 apud SILVA; BOIA, 2003, p.53):

Muitas vezes, em decorrência de serem portadores de deficiências mais visíveis e evasivas do ponto de vista social, muitas pessoas são segregadas em instituições totais ou fechadas, a fim de que não causem distúrbios entre as pessoas tidas como 'normais'. Este tipo de instituição, a nosso ver, corrobora cada vez mais a ideia de que a sociedade deve manter os 'diferentes' isolados e ao mesmo tempo, mantêlos sobre vigília caritativa e assistencialista.

No entanto, é evidente que os deficientes estavam à mercê de decisões aIheias, sendo tratados isolados da sociedade, deixando-os sob as políticas de assistência e despertando o sentimento de piedade. Essas formas de tratamento que foram dispensadas durante muito tempo às pessoas com deficiência, serviram como combustível para que uma nova visão surgisse na sociedade, onde os deficientes deixaram de ser objeto de compaixão para serem detentores de direitos, de pacientes para consumidores com autonomia e da situação de segregados para inseridos na corrente da sociedade (SASSAKI, 2003).

Os ganhos decorrentes da convivência em sociedade resultaram em mobilizações internacionais. Em nove de dezembro de 1975 foi homologada a primeira "Declaração dos Direitos das Pessoas Deficientes" (SILVA; BOIA, 2003). Apesar de não ter sido a primeira ação com o intuito de estabelecer benefícios para os deficientes, já que antes ocorreram ações isoladas, foi à primeira em nível internacional, pois uma Resoluç̧ão foi aprovada pela Assembleia Geral da Organização das Nações Unidas $(\mathrm{ONU})^{1} \mathrm{e}$, por meio dela, os conceitos a respeito das deficiências começaram a ser disseminados em nível mundial.

Outras ações ocorreram com o decorrer do tempo, como tratados, convenções e leis, as quais foram importantes para as conquistas dos deficientes, entre elas podese destacar a Declaração de Maastricht ${ }^{2}$. O evento que deu origem a essa declaração teve a participação de vários países e foram discutidos assuntos de várias áreas, como economia, política, mudanças climáticas, entre outros. Contou também com repre- 
sentantes dos deficientes, sendo solicitada sua participação na sociedade, como se pode ler em um trecho da referida declaração.

Nós precisamos participar plenamente em nossas sociedades em todos os níveis e, através de nossas organizações, sermos consultados e envolvidos decisivamente em todos os programas e políticas que nos afetem. Nós somos os peritos; o nosso poder precisa ser reconhecido (DECLARAÇÃO DE MAASTRICHT, 1992 apud SASSAKI, 2004).

Como é perceptível, os deficientes começam a reivindicar seus direitos através da participação em eventos, e se apresentam como conhecedores das suas necessidades, precisando do reconhecimento do seu poder através do respeito às decisões que possam vir a afetar suas vidas.

Os avanços referentes à igualdade para todos, não permaneceram apenas em documentos internacionais. No Art. 5 da Constituição Brasileira está disposto que:

Todos são iguais perante a lei, sem distinção de qualquer natureza, garantindo-se aos brasileiros e aos estrangeiros residentes no país a inviolabilidade de direito à vida, à liberdade, à igualdade, à segurança e à propriedade [...] (BRASIL, 2008).

Ao garantir o direito de igualdade e liberdade a todos, não se espera que a legislação deva ser igual para todos, pois as diferenças existem e devem ser respeitadas, mas que os diferentes sejam tratados com suas diferenças para que todos sejam tratados com igualdade.

Para que essa equiparidade fosse oferecida aos deficientes, o Governo Federal através da Lei № 5.626, de 22 de dezembro de 2005, regulamenta a Lei $n^{0} 10.436$, de 24 de abril de 2002, que dispõe sobre a Língua Brasileira de Sinais - Libras, e o art. 18 da Lei $n^{\circ} 10.098$, de 19 de dezembro de 2000, no intuito de promover acessibilidade às comunicações e a sinalização às pessoas com deficiência sensorial, eliminando barreiras de comunicação e estabelecendo técnicas alternativas, facilitando assim seu convívio na sociedade. Mas para que o objetivo dessa lei alcançasse o êxito desejado seria necessária a formação de profissionais intérpretes de escrita em Braille, linguagem de sinais e de guias-intérpretes, para facilitar qualquer tipo de comunicação (BRASIL, 2006).

Dentre essas conquistas que facilitam a compreensão, comunicação e a inclusão da pessoa com deficiência, a normatização para construção e adaptação dos edifícios antigos, utilizando o desenho universal e estabelecendo critérios através das normas $^{3}$ aprovadas na Associação Brasileira de Normas Técnicas (ABNT), foi a que ofereceu melhor condição de acessibilidade às pessoas com deficiência, de acordo com o conteúdo do Decreto № 5.296 de 2 de dezembro de 2004 que estabelece normas gerais e critérios básicos para a promoção da acessibilidade das pessoas porta- 
doras de deficiência ou com mobilidade reduzida, e dá outras providências, conhecida como "Lei da acessibilidade" por determinar a supressão de barreiras e obstáculos nas vias e espaços públicos, no mobiliário urbano, na construção e reforma de edifícios e nos meios de transporte e comunicação (BRASIL, 2006).

Foram diversas leis que beneficiaram os deficientes de um modo geral, no caso particular dos deficientes visuais, a Lei № 11.126, de 27 de junho de 2005, que obteve seu regulamento com o Decreto Lei № 5.904 de 21 de setembro de 2006, permite a acessibilidade, não somente aos deficientes visuais, o que já é garantido pela Constituição, mas também ao cão guia em todos os estabelecimentos, como restaurantes, transportes e outros, com exceção os que estão descritos na lei, como Centro de Tratamento Intensivo (BRASIL, 2006).

A autonomia oferecida aos deficientes por meio do que versam as normas aprovadas da ABNT NBR 9050:2004 tornou-se imprescindível para garantir o direito à acessibilidade de todos os deficientes aos ambientes. No caso específico dos deficientes visuais, a implantação de pisos táteis estabeleceu um pouco de independência aos mesmos.

Esse tipo de alteração no ambiente, sinalização tátil, permite através do contato da bengala com o piso, que a informação seja transmitida de forma eficiente para os deficientes visuais, alertando para possíveis obstáculos existentes, tanto verticais como horizontais. Nos verticais a informação é transmitida para alertar sobre obstáculos com altura entre $0,60 \mathrm{~cm}$ e 2,10 $\mathrm{m}$ de altura. Enquanto que os horizontais representam desníveis de calçadas, guias de calçadas e início ou final de escadas, todos com intuito de fornecer autonomia e independência aos deficientes visuais.

Além dessa prática de acessibilidade para os deficientes visuais, também se fazia necessário um sistema que propiciasse autonomia na leitura, não somente com a ajuda de intérpretes, mas com independência. Assim, os deficientes visuais utilizam o sistema Braille, uma leitura tátil e escrita para pessoa cega, que permite uma forma de escrita eminentemente prática. Essa forma simplificada do entendimento e comunicação da pessoa com deficiência visual visa oferecer condições de interação com a literatura, sem necessidade de ajuda externa, bastando apenas o conhecimento da escrita por parte do deficiente. (BRASIL, 2009).

Esse conjunto de conquistas que os deficientes conseguiram, não foi de forma fortuita, vieram por meio de lutas e reivindicações que representam o desfavorecimento que uma parcela da sociedade sofreu por ser diferente dos cidadãos considerados normais.

Apesar da percepção de avanços com relação à aceitação da deficiência durante o tempo, verificam-se reivindicações eminentes para novas conquistas, como o lazer e o turismo, isso porque segundo Sassaki (2003), o lazer e as viagens de turismo destinados aos deficientes, resumiam-se às viagens ou visitas programadas apenas entre eles, esquecendo da integração em sociedade, que é tão importante para o processo de socialização destas pessoas. 
Analisando o lazer e o turismo, percebe-se que ambos trazem consigo o poder de socialização, possibilitando às pessoas interagirem umas com as outras, mesmo sendo de culturas diferentes. No caso do turismo, Krippendorf (2001, p. 82), relata essa interação cultural:

O turismo se tornou o primeiro instrumento da compreensão entre os povos. Ele permite o encontro de seres humanos que habitam as regiões mais afastadas e são de línguas, raças, religiões, orientação política e posição econômica muito diferente. Ele os reúne. É graças a ele, em grande parte, que estes seres humanos conseguem estabelecer um diálogo entre si, compreender a mentalidade do outro, que, de longe, Ihe parece tão estranho, preenchendo, dessa forma, o fosso que os separa.

Essa relação onde existe uma interação entre as partes envolvidas, representa o funcionamento da atividade turística, não somente na área econômica e política, mas também nas relações sociais e culturais, realidade encontrada também no lazer, atividade utilizada pelo turismo como forma de agregar valor ao produto turístico. Dessa relação entre turista e habitante, e dos praticantes do lazer, são absorvidas, segundo Negrini, et al. (2001), os fatos naturais e culturais que os seres humanos constroem durante a vida, o que mostra tanto a força do turismo como do lazer para a socialização dos indivíduos.

O lazer, por meio das mais diversas atividades associadas a ele, oferece aos indivíduos "novas possibilidades de integração voluntária à vida de agrupamentos recreativos, culturais e sociais; possibilitando o desenvolvimento livre" (DUMAZEDIER, 2004, p. 33).

O conceito de lazer é de difícil compreensão, talvez pelo fato de ser confundido com as várias formas de entretenimento que se apresentam na sociedade. Essas atividades que ocupam o tempo livre e que podem estar relacionadas com o crescimento pessoal e coletivo de cada indivíduo devem ser estudadas de forma clara e objetiva para que as distorções sobre seu entendimento não representem empecilhos para o desenvolvimento dos indivíduos.

Para compreender melhor o lazer, pode-se recorrer, ainda, à definição de Sassaki (2004, p. 34) que define o lazer como:

[...] conjunto de ocupações às quais o indivíduo pode entregar-se de livre vontade, seja para repousar, seja para divertir-se, recrear-se e entreter-se ou, ainda para desenvolver sua informação ou formação desinteressada, sua participação social voluntária ou sua livre capacidade criadora após livrar-se ou desembaraçar-se das obrigações profissionais, familiares e sociais. 
Deficiência e equiparidade: um panorama da acessibilidade aos deficientes visuais no Corredor Cultural de Mossoró (RN)

\section{A construção de espaços para a prática do lazer}

A apropriação ou transformação de espaços criados ou reutilizados como possibilidade de lazer pode ocorrer em casos pontuais, como exemplo pode-se citar bares, restaurantes e teatros, mas além destes exemplos merecem destaque os espaços multifuncionais voltados para o lazer, turismo e cultura que vem se disseminando na atualidade.

Dentro desta lógica destaca-se o caso dos Corredores Culturais, que por proporcionar a junção de vários ambientes, vem demonstrando que é um tipo de construção que traz uma mudança para o local e seus usuários, uma mudança no espaço público, com atividades voltadas para fins de esporte, cultura e lazer.

A ideia de estabelecer um corredor cultural em Mossoró teve início no ano de 1983, quando era então administrada pelo prefeito Dix-Huit Rosado (1982-1988) e foi sancionada a Lei № 148/1983 que criava a zona especial do corredor cultural, de preservação paisagística e ambiental do centro da cidade de Mossoró, área detentora de relevante patrimônio histórico-cultural da cidade, tendo como pano de fundo o momento histórico da comemoração do Centenário da Abolição da Escravatura na cidade ${ }^{4}$.

A referida lei previa a preservação ambiental, a reconstituição e a renovação urbanas relacionadas aos elementos arquitetônicos, artísticos e decorativos presentes e a serem construídos na zona criada. Assim, foram selecionados 58 imóveis entre igrejas; instituições artísticas, culturais e históricas; bancos; instituições socioeducacionais e emissoras de rádio.

Apesar da intenção do poder público em converter a zona especial em área com funcionalidade cultural, não logrou êxito. O projeto ficou esquecido durante dez anos, quando somente em 1993, por meio de um recurso do Ministério da Cultura, foram colocadas placas de identificação nos imóveis do corredor cultural, no entanto nenhum deles foi tombado.

Estas edificações eram, em sua maioria, de propriedade privada. Os proprietários destes edifícios passaram a ver o projeto do corredor como um obstáculo às modificações e vendas dos seus imóveis sendo, portanto ao longo do tempo vendidos, modificados ou demolidos.

O projeto ganha força novamente somente no segundo mandato da prefeita Rosalba Ciarlini Rosado (1997/2000), motivado pelo sucesso de outros projetos de corredores culturais no país. Destarte, é eleita desta vez para o projeto a Avenida Rio Branco, via que atravessa a cidade de Leste a Oeste. Outros elementos contribuíram para a escolha do local: sua relevância histórica; acessibilidade; visibilidade, pois a maioria da população transpõe a avenida nos seus deslocamentos diários, e a propriedade do espaço, pertencente ao poder público municipal, haja vista os imóveis anteriores serem de propriedade privada, fato que no projeto anterior dificultou sua exequibilidade.

Assim sendo, em setembro de 1999 ocorre a inauguração da Estação das Artes 
Elizeu Ventania, prédio da antiga Estação Ferroviária Mossoró-Souza/PB, passando a abrigar o Museu do Petróleo ${ }^{5}$ e a ser espaço de realização dos eventos mais expressivos da cidade, como o Mossoró Cidade Junina e o Auto da Liberdade. Este último retrata fatos históricos do povo mossoroense, os quais dizem respeito à abolição dos escravos, o motim das mulheres, o primeiro voto feminino da América Latina e a resistência a Lampião, fatos históricos detentores de forte poder na construção da identidade cultural local de um povo resistente, corajoso e pioneiro (FELIPE, 2001), ideologias reforçadas pelo poder público local, através dos espetáculos promovidos pela prefeitura, e de edificações como o Memorial da Resistência ${ }^{6}$.

Dessa maneira, sucessivamente nos anos seguintes, foram entregues à população a Praça do Skate em 2002, o Teatro Municipal Dix-Huit Rosado, tendo em anexo a Praça Cícero Dias em 2004, a Praça de Eventos em 2007 e as praças da Criança, da Convivência, dos Esportes e o Memorial da Resistência em 2008, estando previstos ainda, a construção do Parque das Oiticicas e da Praça das Fontes, além de obras viárias, completando as obras de urbanização da Avenida Rio Branco.

Vislumbra-se, então, que a área central da cidade passou por um processo de reestruturação, por meio da reconfiguração, construção e embelezamento de monumentos públicos e outros equipamentos culturais. Este espaço vem se organizando intermediado pela cultura (política e identitária), elementos auxiliares para a constituição da imagem da cidade enquanto "capital cultural do Rio Grande do Norte" (BEZERRA, 2006).

De acordo com Carlos (2007, p.45) "o modo de ocupação de determinado lugar da cidade se dá a partir da necessidade de realização de determinada ação, seja de produzir, consumir, habitar ou viver". Percebe-se que as transformações socioespaciais ocorridas neste espaço vêm estabelecendo novas dinâmicas de uso, especialmente no âmbito do lazer urbano, havendo um reforço dos recursos culturais e lúdicos.

No presente trabalho, foram eleitos quatro espaços do Corredor Cultural de Mossoró para serem avaliados como espaços que podem oferecer lazer aos deficientes visuais, sejam eles habitantes ou visitantes, em relação a sua acessibilidade, são eles: o Teatro Dix-Huit Rosado, o Memorial da Resistência, a Praça da Convivência e a Praça de Esportes procurando entender como atividade de lazer, o que Sassaki (2004) considera poder proporcionar repouso, diversão, recreação e entretenimento, tudo de forma espontânea e desinteressada por parte de quem pratica.

\section{Metodologia da pesquisa}

Para o desenvolvimento deste trabalho foram utilizadas pesquisas bibliográficas, pesquisa de campo e observação direta no espaço do Corredor Cultural de Mossoró. Para tanto foi utilizada máquina fotográfica para registrar as conformidades e não conformidades, como falta ou existência de pisos táteis, acessibilidade às informações e outras barreiras ou acessos existentes.

Também foi feita uma abordagem direta e informal a um funcionário que estava 
prestando serviço no momento da visita, com intuito de descobrir respostas para as dúvidas existentes, como a formação de funcionários que prestam serviços nesses espaços, sejam eles do município ou não.

$\mathrm{Na}$ acessibilidade desses espaços em estudo, procura-se entender quais barreiras estão em maior evidência para a utilização dos equipamentos pelos deficientes visuais, sendo avaliadas as barreiras arquitetônicas, de comunicação, metodológica, instrumental e social para com os deficientes.

\section{Observação no Corredor Cultural de Mossoró}

De acordo com a pesquisa de campo realizada observou-se que ações foram executadas com a intenção de proporcionar acesso aos deficientes no Corredor Cultural, não somente aos deficientes visuais, mas aos deficientes de um modo geral.

No primeiro ambiente observado, o Teatro Dix-Huit Rosado, percebeu-se a existência de rampas (Figura 1) permitindo o acesso dos deficientes ao ambiente, porém nota-se a ausência do piso tátil que tem a função de identificar o início ou final de obstáculo e de servir como guia para os deficientes visuais, como também a falta de identificação em alto-relevo no corrimão existente, o que não permite a acessibilidade de forma independente pelos deficientes visuais.

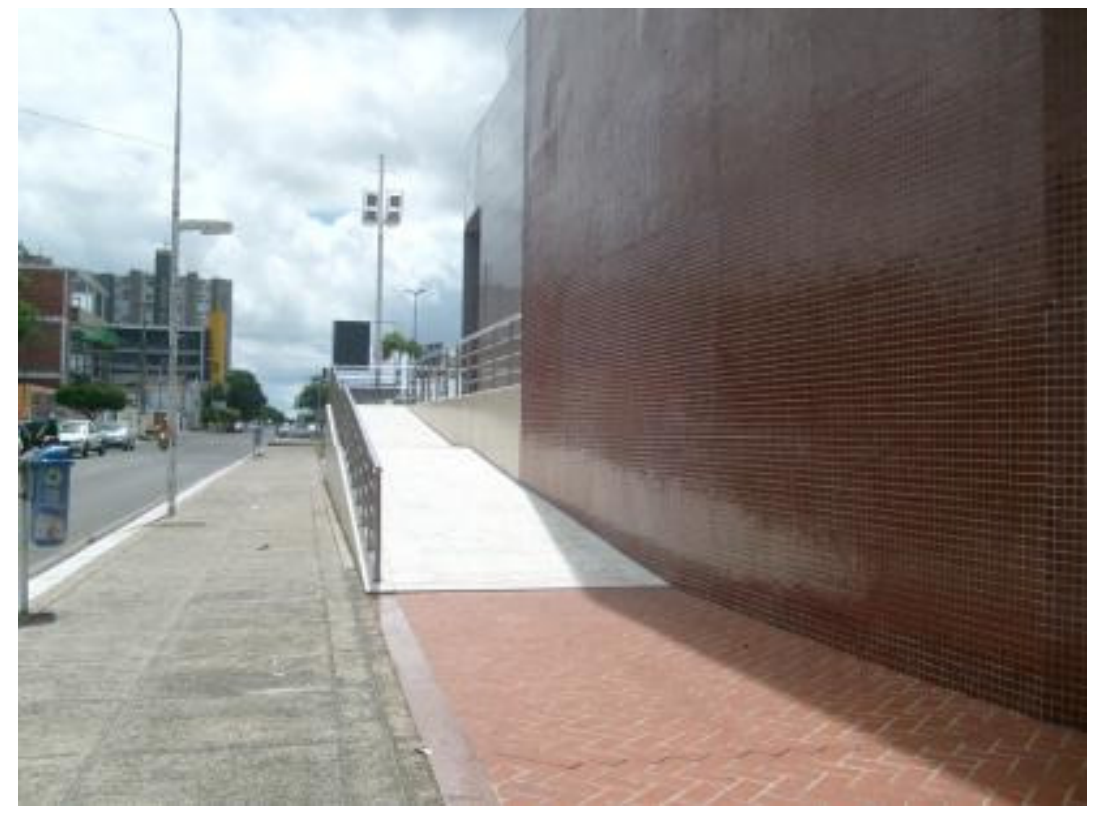

Figura 1: Rampas de acesso ao Teatro Dix-Huit Rosado. Foto: Eider Elias Duarte (jul./2011).

Figure 1: Access ramps Theatre Dix-Huit Rosado. Photo: Eider Elias Duarte (jul./2011).

Como visto anteriormente, o piso tátil fornece ao deficiente visual orientação sobre direção e obstáculos, sejam eles horizontais ou verticais, não somente através do uso da bengala, que transmite ao deficiente as informações, mas também pela to- 
nalidade que faz com que o deficiente com baixa visão consiga a mesma informação através da visão, assim sua implantação torna-se indispensável para a segurança das pessoas que são portadoras desse tipo de deficiência.

$\mathrm{Na}$ área que circunda o Teatro Dix-Huit Rosado é visível a existência de piso tátil de forma discreta, isso pela tonalidade insuficiente entre o piso cinza e o vermeIho do piso tátil, como também a omissão de informação sobre a presença de obstáculos verticais através do piso (Figura 2). No entanto, apesar da tonalidade discreta do piso tátil, sua importância é fundamental para o deficiente com cegueira total, porque apesar da falta de algumas informações na sinalização tátil, se torna eficaz em outras, como para desníveis de calçadas.

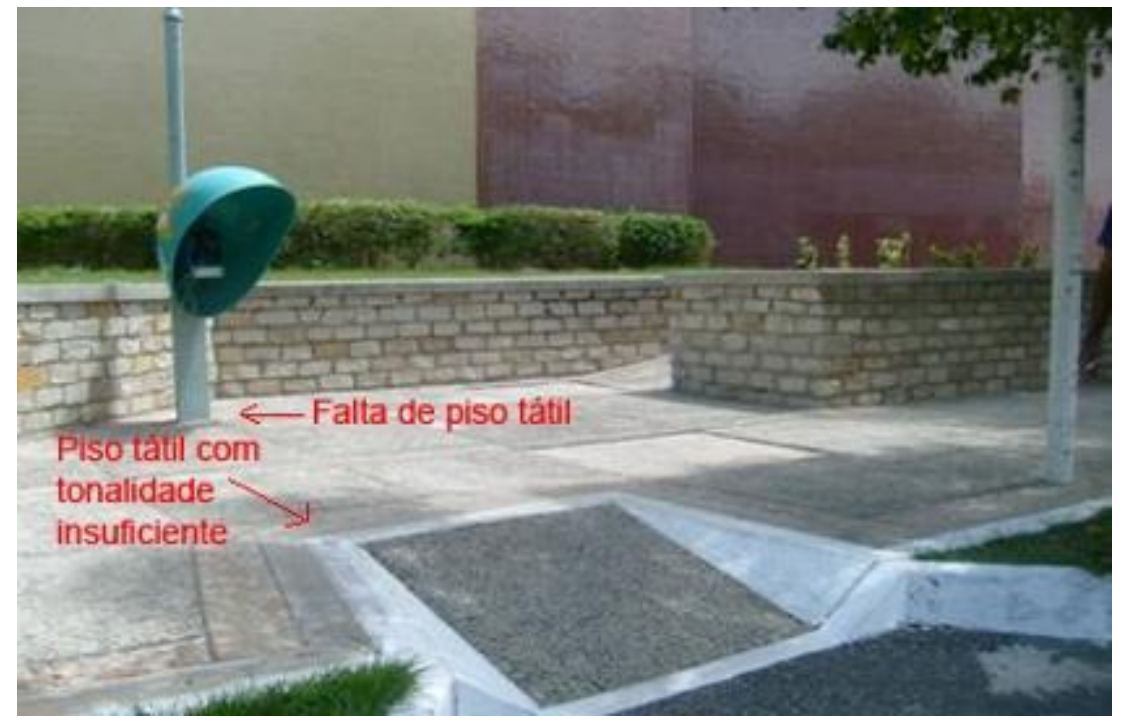

Figura 2: Piso tátil no entorno do Teatro Dix-Huit Rosado. Foto: Eider Elias Duarte (jul./2011). Figure 2: Floor tactile surrounding the Theatre Dix-Huit Rosado. Photo: Eider Elias Duarte (jul./2011).

Outro espaço observado refere-se ao Memorial da Resistência, este equipamento é composto por cinco ambientes que procuram proporcionar aos turistas ou visitantes um panorama de uma parte peculiar da história da cidade, cuja ênfase está na resistência da cidade a invasão de um bando de cangaceiros, com fotos e textos autoexplicativos.

Foi constatado que, nesse ambiente, a acessibilidade arquitetônica é visível através de rampas de acesso e corrimão, além de rampas tanto na calçada que circunda o memorial quanto dentro do próprio ambiente, onde ficam alguns textos autoexplicativos e fotografias (Figura 3). Entretanto, como acontece no Teatro Dix-Huit Rosado, ocorre também a ausência de informação em alto-relevo no corrimão presente no equipamento e a irregularidade quanto a tonalidade entre o piso tátil e o não tátil, fundamental para o deficiente visual com baixa visão, já que o vermelho não se destaca da cor cinza da calçada. 
Deficiência e equiparidade: um panorama da acessibilidade aos deficientes visuais no Corredor Cultural de Mossoró (RN)

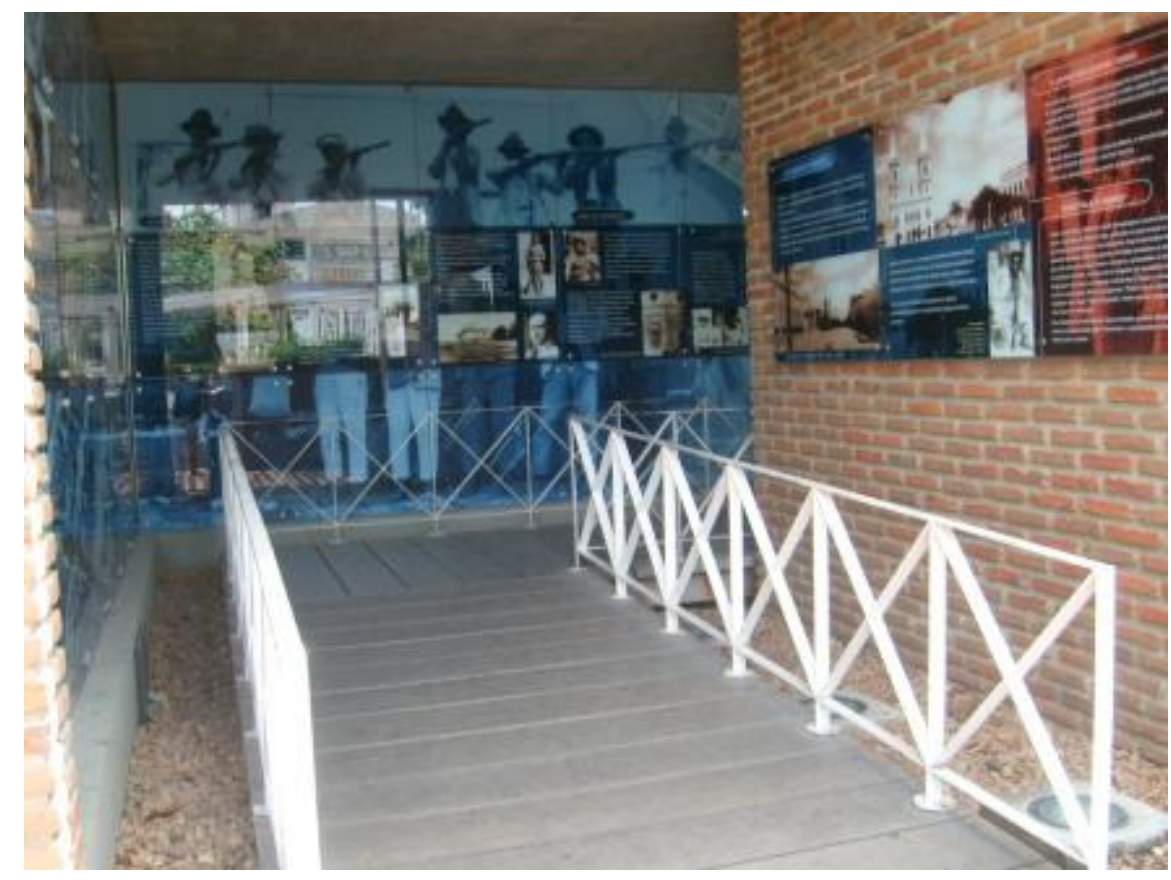

Figura 3: Memorial da Resistência. Foto: Eider Elias Duarte (jul./2011). Figure 3: Memorial da Resistência. Photo: Eider Elias Duarte (jul./2011).

Ainda no memorial, no momento da visita de observação, foi feita uma entrevista informal a um vigilante que estava em horário de trabalho, o mesmo foi indagado sobre a formação recebida para exercer suas funções naquele espaço, que é um museu aberto e recebe visitantes e turistas.

Nós recebemos treinamento da empresa de como abordar os visitantes e turistas, com educação e destreza. Com relação à história que está no Memorial da Resistência, a Prefeitura Municipal de Mossoró até o momento não fez nenhum treinamento. Eu procuro aprender a história da cidade através de livro, para que eu possa transmitir a história de forma eficiente. Tem também uma moça que trabalha na loja de artesanato que faz esse trabalho, mas é espontâneo. Quanto à visita de deficientes visuais, é raro, vem mais os deficientes físicos (cadeirantes).

Sendo o memorial um museu aberto e um espaço público, deveria estar em conformidade com a ABNT NBR 9050:2004, sendo um espaço acessível a todos, já que foi inaugurado em 2008, depois da "Lei da acessibilidade". Como já mencionado possui painéis e fotos autoexplicativos, entretanto nestas fotos e painéis não está disponível nenhuma informação em Braille, além disso, como foi relatado na entrevista, os funcionários do local são treinados para suas funções, ficando claro que não inclui dar informação sobre o conteúdo do memorial. 
O terceiro espaço observado foi a Praça da Convivência. Esta também oferece acessibilidade através de rampas e com uma diferenciação de piso tátil logo no seu início, podendo-se observar uma tonalidade diferente das outras praças, com o piso cinza contrastando com o amarelo do piso tátil (Figura 4). Entretanto, no interior da praça isso deixa de existir, o piso deixa de ser cinza e passa a ser vermelho, o que para o deficiente com baixa visão deixa de ser perceptível.

Ainda com relação à acessibilidade na Praça da Convivência, o estacionamento contém o total de 28 vagas, sendo apenas uma destinada a deficiente (Figura 4), sendo sua identificação no sentido vertical.

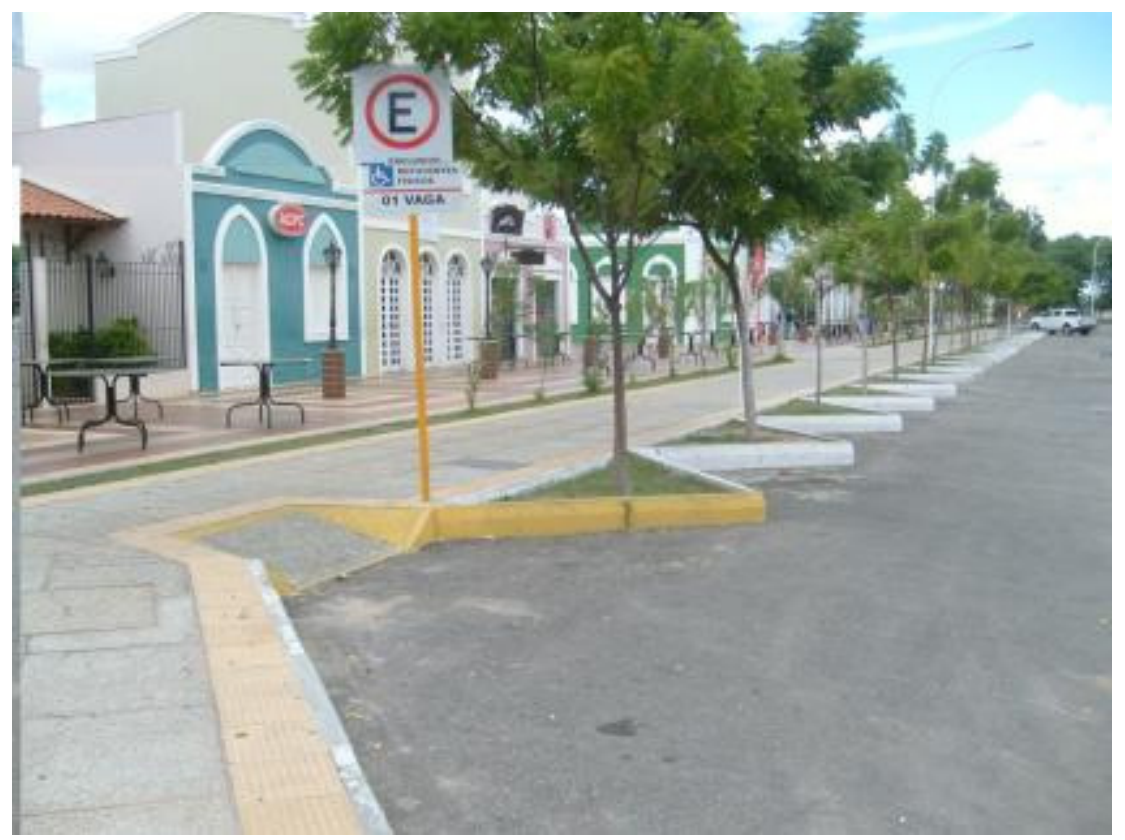

Figura 4: Piso tátil e estacionamento para deficientes na Praça da Convivência.

Foto: Eider Elias Duarte (jul./2011).

Figure 4: Floor tactile and disabled parking in the Praça da Convivência.

Photo: Eider Elias Duarte (jul./2011).

Como já mencionado anteriormente, é notória a inconsistência da tonalidade do piso tátil no interior da Praça da Convivência, como também sua localização, que em alguns momentos está com mesas e cadeiras sobre a guia, devido à distribuição indiscriminada da mobília realizada pelos funcionários e proprietários dos bares e restaurantes no interior da praça.

Em outra localização, ainda no interior da mesma praça, essa mesma guia encontra-se entre bancos e muretas que separam o jardim (Figura 5). Essa sinalização inadequada, que é feita por omissão ou falta de conhecimento dos construtores, pode ocasionar constrangimento para os deficientes visuais, bem como a distribuição aleatória da mobília dos empreendimentos, já que tanto um como o outro podem ocasionar acidentes e transtornos aos deficientes visuais. 
Deficiência e equiparidade: um panorama da acessibilidade aos deficientes visuais no Corredor Cultural de Mossoró (RN)

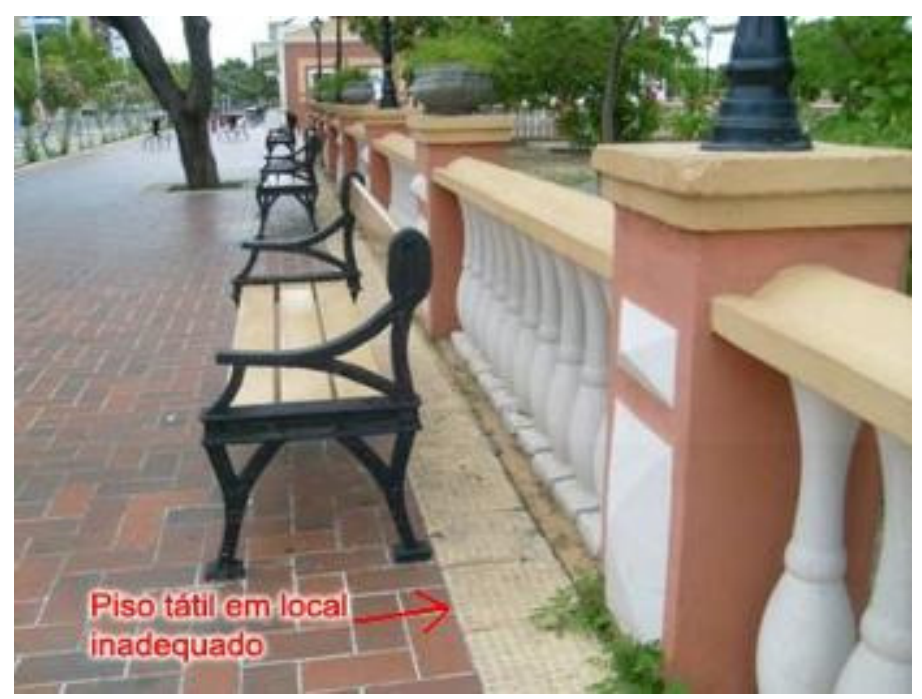

Figura 5: Guia entre bancos e muretas na Praça da Convivência. Foto: Eider Elias Duarte (jul./2011).

Figure 5: Guide between benches and low walls in the Praça da Convivência.

Photo: Eider Elias Duarte (jul./2011).

Outro fato relevante para a acessibilidade dos deficientes na Praça da Convivência são os banheiros destinados aos deficientes (Figura 6). Estes foram construídos separados dos outros banheiros, mas com os acessórios necessários para adequação aos deficientes, como barras de apoio e sanitários especiais, o que facilita o uso para cadeirantes, mas sem muita relevância para o deficiente visual, já que não existe identificação em alto-relevo e os deficientes visuais não necessitam de um espaço maior para se locomoverem.

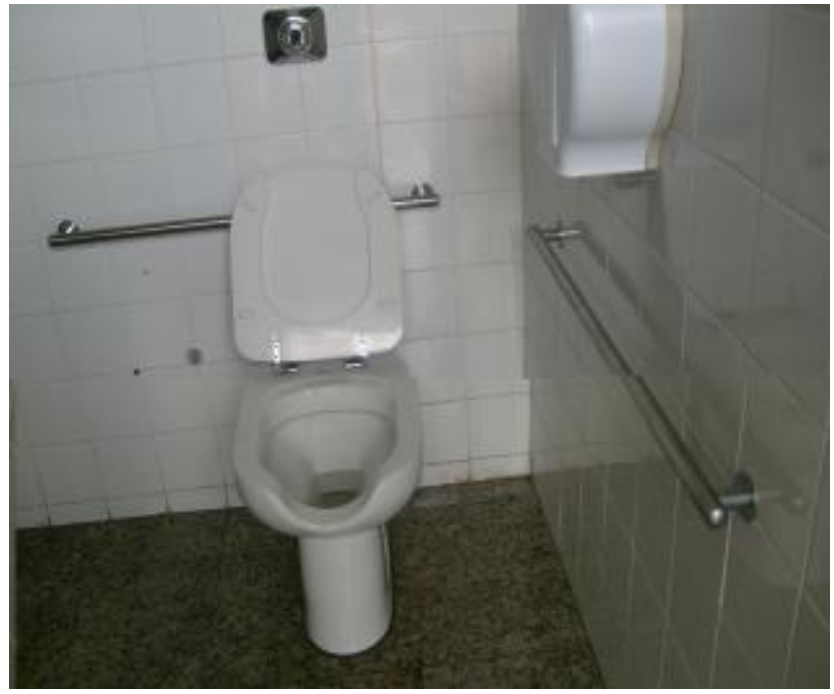

Figura 6: Banheiros para deficientes na Praça da Convivência. Foto: Eider Elias Duarte (jul./2011). Figure 6: Bathrooms disabled in the Praça da Convivência. Photo: Eider Elias Duarte (jul./2011). 
O último espaço observado na visita foi a Praça de Esportes. Embora exista a possibilidade de desenvolvimento para os deficientes visuais nesse espaço de lazer, já que o espaço é composto por algumas quadras poliesportivas, onde a possibilidade para a prática de diversos tipos de atividades esportivas é uma realidade, tais como futebol para cegos e Goalball ${ }^{P}$, que são modalidades esportivas para deficientes visuais; a praça não é utilizada por esse público, durante o período de observação não foi visto nenhum deficiente visual nesta praça. A sinalização para os deficientes se resume a pisos táteis em volta das quadras e a rampas de acesso em torno da praça.

A acessibilidade nesse ambiente é observada da mesma forma que nas outras praças, com um piso tátil com tonalidade insuficiente para o deficiente visual com baixa visão, repetindo o piso cinza com o vermelho, além disso, duas vagas de estacionamento para cadeirantes, sendo identificadas através de pintura horizontal com tonalidade amarela, mas desbotada pela ação do tempo (Figura 7). A inadequação na sinalização se apresenta como um dos fatores para a não acessibilidade dos portadores de deficiência visual nesse ambiente.

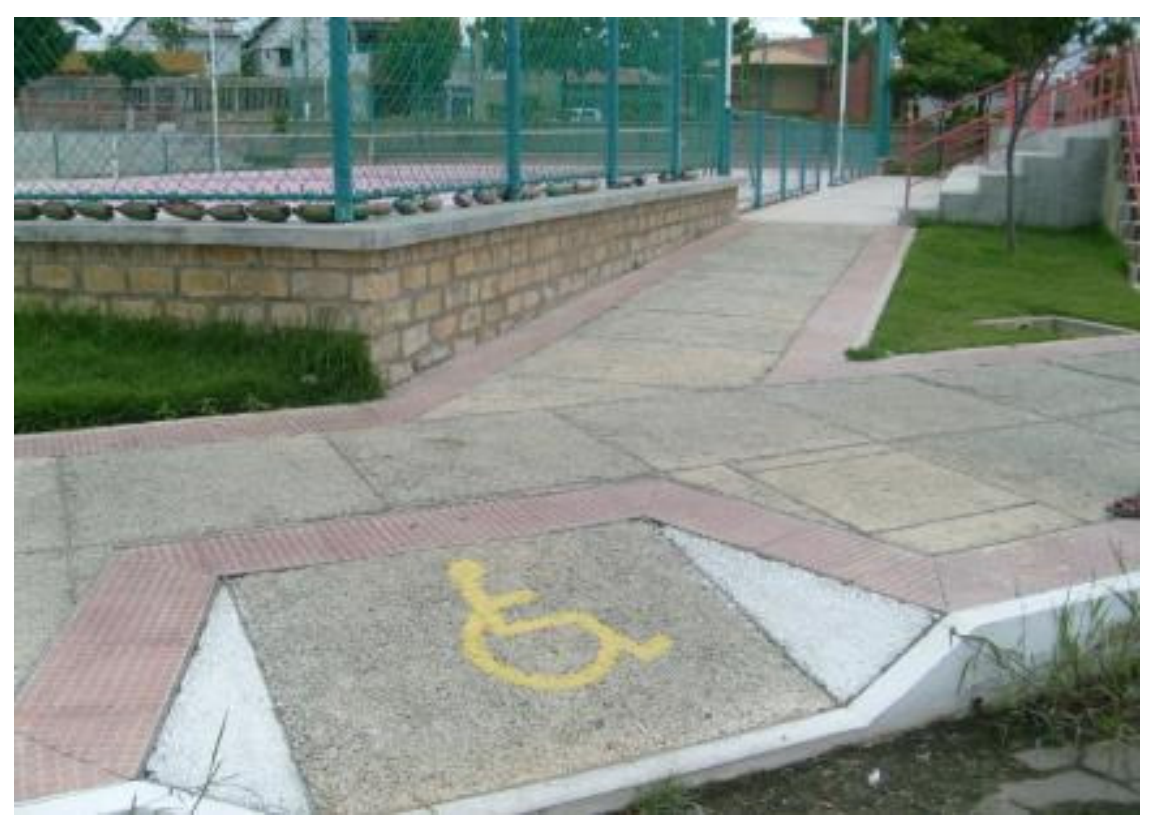

Figura 7: Acessibilidade insuficiente para prática de esportes. Foto: Eider Elias Duarte (jul./2011).

Figure 7: Accessibility insufficient to sports. Photo: Eider Elias Duarte (jul./2011).

Todos os locais observados no Corredor Cultural de Mossoró, devido ao seu conteúdo de caráter esportivo, cultural e de entretenimento, podem propiciar possibilidades de integração, interação cultural e o processo de socialização (SASSAKI, 2003; KRIPPENDORF, 2001) que podem ocasionar desenvolvimento livre para as pessoas que dele fazem uso (DUMAZEDIER, 2004), no entanto as não conformidades existentes, especialmente no que diz respeito à sinalização tátil para os deficientes visuais, 
dificultam e, podem mesmo impossibilitar o acesso e o uso desses espaços, que são públicos, por este público de forma independente, o que caracteriza que estes espaços não são totalmente acessíveis, em conformidade com a "Lei da acessibilidade" e a ABNT NBR 9050:2004, mesmo tendo sido entregues a cidade no ano de 2008, ou seja, após a publicação das normas e da referida lei.

\section{Considerações finais}

Esta pesquisa partiu do pressuposto que não existia acessibilidade para os deficientes visuais nos ambientes pesquisados no Corredor Cultural de Mossoró, mas durante o decorrer da pesquisa verificou-se a existência de rampas, pisos táteis dentre outros mecanismos que atendem aos portadores de necessidades especiais.

A construção do Corredor Cultural de Mossoró proporcionou aos mossoroenses um espaço com vários ambientes onde a prática do lazer é evidente, mas durante a pesquisa percebeu-se que apesar dessa construção permitir um pouco de acessibilidade aos deficientes visuais, outras medidas ainda necessitam serem tomadas, a exemplo da formação de guias intérpretes, o que está assegurado na Lei № 10.098 de 19 de dezembro de 2000. Nos locais eleitos para a pesquisa, a ausência desse profissional foi percebida com maior ênfase no Memorial da Resistência, onde os textos acerca da história expostos nos painéis não tem como ser apreendidos pelos deficientes visuais.

Outro fato que se deve levar em consideração na hora de se construir pensando em espaços totalmente acessíveis, é a contratação de profissionais que usem o desenho universal com adaptação para acessibilidade de todos. Refletindo sobre isso se percebe que a acessibilidade para os deficientes visuais nos ambientes pesquisados no Corredor Cultural de Mossoró existe, mas timidamente, já que a construção dotou o espaço com piso tátil e rampas, além de banheiros adaptados e corrimão para deficientes, mas omitem nessas mesmas construções a sinalização tátil, informação necessária para a independência dos deficientes visuais.

Esta temática e a área de estudo ainda carecem de mais informações e mais pesquisas, a exemplo da verificação das medidas corretas da Associação Brasileira de Normas Técnicas utilizadas nessas construções. A adaptação dos espaços de lazer, públicos ou privados, construídos como atrativos turísticos na cidade de Mossoró às diversas formas de necessidades especiais, também se constitui em estudo relevante no que diz respeito a esta temática, além da investigação da relação entre os trabalhadores dos bares e restaurantes e os deficientes, dentre outros assuntos que se relacionem à acessibilidade, seja ela arquitetônica, metodológica, instrumental ou ética e que venham a ampliar os resultados encontrados. 


\section{Referências bibliográficas}

BEZERRA, A.C.A. Pelas margens da cidade e no meio da festa: A (re) invenção das festas e da identidade no espaço urbano de Mossoró-RN. 208 f. 2006. Tese (Doutorado em Geografia) - Programa de Pós-Graduação em Geografia - Universidade Federal Fluminense, Niterói/RJ, 2006.

BRASIL. Ministério do Turismo. Secretaria Nacional de Políticas de Turismo. Coordenação Geral de Segmentação. Turismo e acessibilidade: manual de orientações. $2^{\underline{a}}$ ed. Brasília: Mtur, 2006.

BRASIL. Constituição (1988). Constituição da República Federativa do Brasil: $29^{a}$ ed. Brasília: Câmara dos Deputados, Coordenação de publicações, n. 45, 2008. (Série textos básicos).

BRASIL. Ministério do Turismo. Turismo acessível: introdução a uma viagem de inclusão. Brasília: Ministério do Turismo, 2009. Disponível em:<http:// www.turismo.gov.br>. Acesso em: 08 maio 2011.

CÂMARA, F.C. Um corredor de memória: a utilização do patrimônio histórico arquitetônico de Mossoró como justificativa de mando (1983 - 2007). 2008. 80 f. Monografia (Especialização em História do Nordeste) - Universidade do Estado do Rio Grande do Norte, Faculdade de Filosofia e Ciências Sociais, Mossoró/RN, 2008.

CARLOS, A.F.A. A cidade. 8.ed. São Paulo: Contexto, 2007.

DUMAZEDIER, J. Lazer e cultura popular. Tradução: Maria de Lourdes Santos Machado. 3. ed. São Paulo: Editora Perspectiva S.A, 2004.

FELIPE, J.L.A. A (re)invenção do lugar: os Rosados e o "país de Mossoró". João Pessoa: Ed. Gradset, 2001.

NEGRINE, A.N.; BRADACZ, L.; CARVALHO, P.E.G. Recreação na hotelaria: o pensar e o fazer lúdico. Caxias do Sul: EDUCS, 2001.

KRIPPENDORF, J. Sociologia do turismo: para uma nova compreensão do lazer e das viagens. 3. ed. São Paulo: Aleph, 2001.

SASSAKI, R.K. Pessoas com deficiência e os desafios da inclusão. Revista Nacional de Reabilitação, 2004. Disponível em: <http://bauru.apaebrasil.org.br>. Acesso em: 11 maio 2011.

SASSAKI, R.K. Inclusao no lazer e turismo: em busca da qualidade de vida. São Paulo: Áurea Editora, 2003.

SILVA, Y.F.; BOIA, Y.I.K. Turismo e responsabilidade social: Uma Reflexão sobre os Direitos das Pessoas com Necessidades Especiais. Revista Visão e Ação. Itajaí, SC. v. 5, n. 1, jan./abr. 2003. Disponível em:<http://www.univali.br>. Acesso em: 08 maio 2011.

SILVA, Y.F.; GONÇALVES, P.S. A estrutura hoteleira de Balneário Camboriú para turistas portadores de necessidades especiais. Revista Visão e Ação. Itajaí, SC. v. 8, n. 1, jan./abr. 2006. Disponível em:<http://www.univali.br>. Acesso em: 08 maio 2011. 


\section{Notas:}

${ }^{1}$ Instituição internacional formada por 192 Estados soberanos, fundada após a Segunda Guerra Mundial para manter a paz e a segurança no mundo.

${ }^{2}$ Nome de cidade localizada na Região Sul da Holanda (Reino dos Países Baixos).

${ }^{3}$ ABNT NBR 9050:2004 - estabelece critérios e parâmetros técnicos para:

1.3. Proporcionar à maior quantidade possível de pessoas, independentemente de idade, estatura ou limitação de mobilidade ou percepção, a utilização de maneira autônoma e segura do ambiente, edificações, mobiliário, equipamentos urbanos e elementos.

1.3.1 Todos os espaços, edificações, mobiliário e equipamentos urbanos que vierem a ser projetados, construídos, montados ou implantados, bem como as reformas e ampliações de edificações e equipamentos urbanos, devem atender ao disposto nesta Norma para serem considerados acessíveis.

${ }^{4}$ (CÂMARA, 2008).

${ }^{5}$ Museu que retrata a história do petróleo no estado do Rio Grande do Norte, instituído pela parceria entre a Prefeitura de Mossoró e a Petrobras.

${ }^{6}$ Estrutura com exposição permanente de fotos e textos que retratam a cidade de Mossoró na década de 1920, período em que a cidade foi atacada pelo bando do cangaceiro Lampião (Virgulino Ferreira da Silva), que no início do século XX aterrorizava o sertão nordestino. No entanto, os homens da cidade resistiram à invasão, sendo os mesmos homenageados no memorial, assim como as principais figuras do cangaço.

${ }^{7}$ Goalball é um esporte praticado por pessoas cegas ou de pouca visão, com o objetivo de arremessar uma bola sonora com as mãos no gol do adversário.

Eider Elias Duarte: Universidade do Estado do Rio Grande do Norte, Mossoró, RN, Brasil E-Mail: eiderelias@yahoo.com.br

Michele de Sousa: Universidade do Estado do Rio Grande do Norte, Mossoró, RN, Brasil E-Mail: sousa.michele@gmail.com

Link para o currículo Lattes: http://lattes.cnpq.br/6455223131688574

Data de submissão: 30 de junho de 2012

Data de recebimento de correções: 08 de maio de 2013

Data do aceite: 14 de maio de 2013

Avaliado anonimamente 
Valduga, M.C.; Moura, R.L. A segurança como elemento da hospitalidade: a presença das Unidades de Polícia Pacificadora como elemento facilitador do desenvolvimento do turismo nas favelas do Rio de Janeiro (RJ). Revista Brasileira de Ecoturismo, São Paulo, v.6, n.3, ago/out-2013, pp.630-647.

\title{
A segurança como elemento da hospitalidade: a presença das Unidades de Polícia Pacificadora como elemento facilitador do desenvolvimento do turismo nas favelas do Rio de Janeiro (RJ)
}

\author{
Security as part of hospitality: the presence of the Pacifying Police Units as \\ facilitator of the development of tourism in the favelas of Rio de Janeiro (RJ)
}

\section{Manoela Carrillo Valduga, Reginaldo Lima de Moura}

\section{RESUMO}

O presente artigo versa acerca da temática do desenvolvimento do Turismo em Favelas a partir da análise das relações de hospitalidade configuradas após a implementação das Unidades de Polícia Pacificadora (UPPs) nas comunidades Dona Marta, ChapéuMangueira, Pavão-Pavãozinho-Cantagalo e Tabajaras - Cabritos, todas localizadas na cidade do Rio de Janeiro. O objetivo da pesquisa é identificar, a partir do olhar da mídia, a influência da hospitalidade doméstica, comercial e pública na conformação da favela como destino turístico. Como procedimento metodológico, optou-se pela busca de informações na mídia impressa diversa em reportagens que abordassem a temática do Turismo em favelas. Como resultado preliminar, infere-se que a prática da hospitalidade nas três categorias abordadas encontra espaço na tessitura social após implementação das UPPs e constitui papel fundamental para o desenvolvimento da favela turística. Desta forma, é importante pensar quais são as ações públicas que os gestores estão desenvolvendo para tornar a favela um produto turístico e, ainda, se as comunidades estudadas estão preparadas para receber futuros fluxos turísticos.

PALAVRAS-CHAVE: Hospitalidade; Turismo em Favelas; Unidades de Polícia Pacificadora; Rio de Janeiro.

\section{ABSTRACT}

This article focus on tourism development in local communities and the analysis of the relations of hospitality configured after the implementation of the Police Pacification Units (UPPs) in Dona Marta, Chapéu-Mangueira, Pavão-Pavãozinho-Cantagalo and Tabajaras - Cabritos - all located in the city of Rio de Janeiro. The goal is to identify, from the look of the media, the influence of domestic hospitality, commercial and public in shaping the favela as a tourist destination. As methodological procedure, we chose to search for information in print different reports that focus on the theme of tourism in the favelas. As a preliminary result, it is inferred that the practice of hospitality in the three categories is addressed in the social space after implementation of UPPs and constitutes fundamental role in the development of tourism. Is important to think about what are the the public actions managers are developing to make the favela a tourist product, and also if the communities studied are prepared to receive future tourist flows.

KEYWORDS: Hospitality; Tourism in Favelas;: Pacifying Police Units; Rio de Janeiro. 


\section{Introdução}

A discussão apresentada no presente artigo permeia entre os estudos da hospitalidade francesa a americana. A primeira traz os autores do campo da sociologia e da antropologia, que compreende a hospitalidade como algo inerente às relações dos seres humanos. Em contraponto, a corrente americana estuda o comportamento da hospitalidade a partir das trocas monetárias, onde o valor de troca é o que comanda as relações de hospitalidade (CAMARGO, 2004; MORRISON; LASHLEY, 2004). Nas relações sociais que permeiam os encontros nas áreas turísticas das comunidades, lançaremos mão dos pressupostos da acessibilidade, legibilidade e identidade (GRINOVER, 2007) para a compreensão da hospitalidade.

Este trabalho pretende analisar de que forma as relações de hospitalidade nas favelas cariocas mudaram após a instalação das Unidades de Polícia Pacificadora e quais são as perspectivas para a atividade do turismo.

Para dar conta da compreensão das lógicas locais de Hospitalidade, são estudados o processo de mudança da prática da hospitalidade urbana nas favelas cariocas; o cenário da hospitalidade comercial nas favelas cariocas; identificação sobre se a prática da hospitalidade social coloca a favela num cenário positivo para o turismo e avaliar se depois da implantação das Unidades de Polícia Pacificadora a favela ficou mais segura, possibilitando assim uma perspectiva positiva para o turismo.

As considerações apresentadas no presente trabalho foram feitas por meio da análise de conteúdo de trinta reportagens, prospectadas no período de dezembro de 2008 a julho de 2011, onde se procurou tratar, em linhas gerais, aspectos da hospitalidade urbana, comercial e doméstica; além da questão da segurança. Outra reflexão realizada tratou o modo como essas mudanças estão auxiliando no fomento da atividade turística.

Eventualmente foram tratadas reportagens referentes a outras comunidades, com a finalidade de agregar informações que legitimam as já apresentadas sobre as favelas analisadas em questão, entretanto a discussão não foi aprofundada.

É importante ressaltar que os apontamentos realizados no presente trabalho são frutos de uma pesquisa que tem como principal análise o discurso midiático. As análises foram centradas na metodologia proposta por Bardin (1977) na sua narrativa "Análise do Conteúdo". A autora ressalta que a análise qualitativa não rejeita toda e qualquer forma de quantificação. Nestes termos, o analista pode/deve recorrer a testes quantitativos para apresentar alguma similaridade nos discursos analisados.

Desta forma, a pesquisa não irá ater-se a aspectos concernentes a imparcialidade das informações, mais sim, no que tais informações podem gerar para a população das comunidades analisadas, abrindo, dessa maneira, novos campos de pesquisa para fomentar os estudos da hospitalidade e do turismo.

A imparcialidade da análise está relacionada ao nível de envolvimento que o leitor tem com a mídia divulgadora da noticia, ou até mesmo com a forma que a manchete é divulgada. Nesse sentido, percebe-se que, realizar uma leitura imparcial dos fatos é algo um tanto quanto utópico. 
Posto isto, foi realizada uma pré-análise de todos os materiais utilizados, assim como, de todo material necessário para melhor explicar este fenômeno. O motivo para essa análise, como explica Bardin (1977, p.21), é que na análise qualitativa "é a presença ou a ausência de uma dada característica de conteúdo ou um conjunto de características num determinado fragmento de mensagem que é tomado em consideração".

Desta forma, a análise das reportagens buscou apoio no referencial teórico. Por último, foi feita uma interpretação referencial, onde as reflexões puderam apontar a existência ou não das questões norteadoras.

$\mathrm{Na}$ análise qualitativa foram verificadas todas as temáticas das reportagens do período da pesquisa. Neste sentido, não foi levado em consideração à frequência com a qual o assunto foi abordado, ainda que só fosse relatada uma vez, a matéria foi levada em conta.

\section{Unidade de Polícia Pacificadora e as comunidades investigadas}

Primeiramente, é importante ressaltar que, antes da Unidade de Policia Pacificadora, outras políticas de segurança já tinham sido implantadas na cidade do Rio de Janeiro, como, por exemplo, o Posto de Policiamento Comunitário (PCC), que foi implantado pela gestão anterior ao do atual governador do Estado Sergio Cabral, porém sem resultados satisfatórios. O que ocorre é que não temos pesquisas suficientes na área para identificar se esses resultados aconteceram por falta de interesse público ou se realmente no projeto anterior faltava experiência (treinamento) por parte dos agentes da policia.

O conceito de Unidade de Polícia Pacificadora traz consigo o conceito de "policia de proximidade". Na verdade a intenção inicial se dá pela interação com os jovens antes de repressão. A ideia central do programa é tentar realizar uma aproximação com a população das favelas cariocas, principalmente na tentativa de evitar um confronto armado no futuro, com a proposta de recuperar os territórios ocupados por traficantes e milicianos.

Hoje, as Unidades de Polícia Pacificadora já estão presentes nas comunidades do Morro Santa Marta (Botafogo - Zona Sul); Cidade de Deus (Jacarepaguá - Zona Oeste), Jardim Batam (Realengo - Zona Oeste); Babilônia e Chapéu Mangueira (Leme - Zona Sul); Pavão-Pavãozinho e Cantagalo (Copacabana e Ipanema - Zona Sul); Tabajaras e Cabritos (Copacabana - Zona Sul); Providência (Centro); Borel (Tijuca - Zona Norte); Andaraí (Tijuca); Formiga (Tijuca); Salgueiro (Tijuca); e Turano (Tijuca). São 200 mil pessoas beneficiadas pelo projeto.

Desenvolvida estrategicamente pela atual gestão da Secretaria de Estado de Segurança, as Unidades de Polícia Pacificadora trabalham com os princípios de Polícia comunitária.

É importante ressaltar que a polícia comunitária é um conceito e uma estratégia fundamentada na parceria entre população e as instituições da área de segurança pú- 
blica. O governo do Estado está investindo cerca de $R \$ 15$ milhões na contratação e qualificação de policiais para que, até 2016 estejam formados por volta de 60 mil policiais.

Das Unidades de Polícia Pacificadoras apresentadas anteriormente, vamos trabalhar com quatro delas (Tabela 1), todas localizadas na Zona Sul da cidade do Rio de Janeiro.

Tabela 1: Comunidades atendidas e ficha técnica.

Table 1: Communities served and technical records.

\begin{tabular}{|c|c|}
\hline Comunidade & Ficha técnica \\
\hline Dona Marta & $\begin{array}{l}\text { Inauguração: 19/12/2008; Comandante: Capitã Priscilla } \\
\text { Azevedo; Contato: 2334-4099. Efetivo: } 123 \text { PMs; Benefi- } \\
\text { ciados: } 10 \text { mil. Comunidade atendida: Santa Marta; Bair- } \\
\text { ros: Botafogo e Humaitá; RISP: 01; AISP: 02; PCERJ: 10a } \\
\text { DP; PMERJ: 20 BPM. }\end{array}$ \\
\hline Chapéu-Mangueira & $\begin{array}{l}\text { Inauguração: 10/06/09; Comandante: Capitão Felipe Ma- } \\
\text { galhães dos Reis; Contato: 2334-7341; Efetivo: } 100 \text { PMs; } \\
\text { Beneficiados: } 10 \text { mil. Comunidades atendidas: Babilônia } \\
\text { e Chapéu Mangueira; Bairro: Leme; RISP: 01; AISP: } 19 . \\
\text { PCERJ: } 12^{2} \text { DP; PMERJ: } 19^{\circ} \text { BPM. }\end{array}$ \\
\hline Pavão-Pavãozinho-Cantagalo & 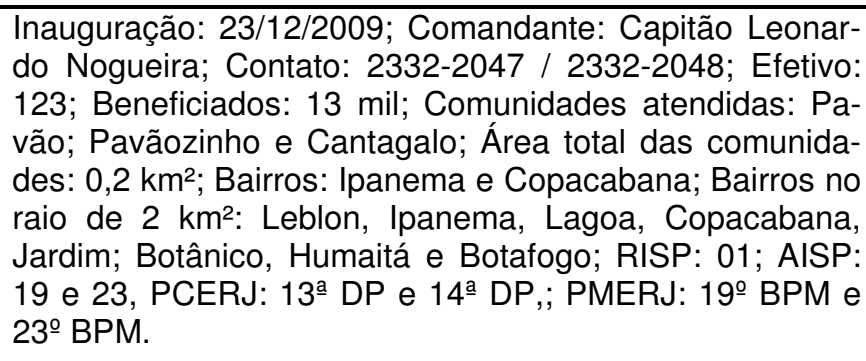 \\
\hline Tabajaras - Cabritos & $\begin{array}{l}\text { Inauguração: 14/01/2010; Comandante: Capitão Renato } \\
\text { Sena; Efetivo: } 120 \text { PMs; Beneficiados: } 7 \text { mil; Comunida- } \\
\text { des atendidas:; Ladeira dos Tabajaras, Morro dos Cabri- } \\
\text { tos, Pico do Papagaio e Mangueira (em Botafogo); Área } \\
\text { total das comunidades: 0,1 km²; Bairros: Copacabana e } \\
\text { Botafogo; Bairros no raio de } 2 \mathrm{~km}^{2} \text { : Jardim Botânico, La- } \\
\text { goa, Santa Teresa, Ipanema, Humaitá, Cosme Velho, } \\
\text { Botafogo, Laranjeiras, Copacabana, Urca e Leme; RISP: } \\
\text { 01; AISP: } 02 \text { e 19; PCERJ: } 12^{\mathrm{a}} \text { DP e 10ª DP; PMERJ: } \\
\text { BPM e 19 BPM. }\end{array}$ \\
\hline
\end{tabular}

Fonte: Elaboração própria. Source: authors. 


\section{O turismo nas favelas após a implementação das UPPs}

A partir da análise das reportagens, o presente artigo propõe que 2008 seja considerado como o ano da implantação, 2009 o ano da expansão e 2010 o ano da consolidação e ano de 2011 foram apresentadas algumas notícias e perspectivas de como se desenvolveu a relação da favela com a Unidade de Polícia Pacificadora.

\section{8: da implantação}

$\mathrm{O}$ ano de 2008 foi um ano de muitas mudanças para a cidade do Rio de Janeiro, principalmente para as favelas cariocas. A cidade vivenciava um momento muito complexo no que tange a questão da segurança pública e muitas ações já tinham sido colocadas em prática, porém com resultados insatisfatórios.

O Posto de Policiamento Comunitário (PCC), localizado em algumas favelas do Rio de Janeiro, não tinha apresentado resultados satisfatórios para a secretaria de segurança da cidade do Rio de Janeiro. Neste panorama de insegurança e após vários estudos realizados pela secretaria de segurança da atual gestão, surgiu primeira Unidade de Polícia Pacificadora, implantada na favela Dona Marta, no bairro de Botafogo.

A Unidade de Polícia Pacificadora foi implantada na favela Dona Marta em 19 de dezembro de 2008. Na verdade, o processo de pacificação já estava em prática há pelo menos um mês antes da implantação definitiva da Unidade de Polícia Pacificadora. Como foi a primeira favela a ser pacificada, a comunidade Dona Marta serviu de laboratório para a Secretaria de Segurança, que posteriormente a implantou em outras comunidades.

Para o atual Secretário de Segurança José Mariano Beltrame, "a nova polícia de segurança para as comunidades carentes só funciona se houver a chegada de outros serviços e a presença de Estado, além da polícia" o Secretário ressalta ainda que "não adianta implantar um novo policiamento e não dar para o cidadão o restante. Não adianta tirar o 'gatonet' e não colocar a TV cabo formal. E isso já sai da segurança pública".

Estes serviços de infraestrutura como afirma Grinover (2007) são partes fundamentais da categoria acessibilidade, para que ocorra a prática da hospitalidade. Iniciase então, na favela Dona Marta um processo de hospitalidade urbana, que segundo Grinover faz parte de um conjunto de ações para que um local possa ser considerado hospitaleiro.

Grinover (2007 p.142) ressalta ainda que "faz parte da cidadania a incorporação de território como espaço não só de habitação, mas também de vivência e convivência". Para o autor "passear prazerosamente e com segurança" (ibidem) são aspectos necessários para a não segregação dos espaços urbanos, que nos grandes centros urbanos tem se tornado constante.

Como a implantação da Unidade de Polícia Pacificadora ocorreu no final do a- 
A segurança como elemento da hospitalidade: a presença das Unidades de Polícia Pacificadora como elemento facilitador do desenvolvimento do turismo nas favelas do Rio de Janeiro (RJ)

no de 2008, a mídia não deu ênfase na cobertura desse evento. Só no ano seguinte pode-se perceber a dimensão dessa ação por parte da Secretaria de Segurança e do governo do Estado.

\section{9: da expansão}

Após a primeira pacificação do morro Dona Marta, no ano de 2009 ocorreu à expansão das Unidades de Polícia Pacificadora. Aproximadamente dois meses após ser implantada no Dona Marta, estava na hora da Unidade de Polícia Pacificadora chegar à Cidade de Deus, favela localizada em Jacarepaguá. O ano de 2009 pode ser considerado um ano de mudanças, dois dias após a implantação da Unidade de Polícia Pacificadora da Cidade de Deus, foi vez comunidade Jardim Batam, localizada no Bairro Realengo.

Quatro meses depois, mais precisamente em 10 de junho de 2009, foi a vez da favela da Babilônia - Chapéu Mangueira localizada no bairro do Leme. No final do ano de 2009 foi inaugurada mais uma Unidade de Polícia Pacificadora na favela Cantagalo-Pavão-Pavãozinho.

Visto isso, os reflexos da Unidade de Polícia Pacificadora nas comunidades cariocas começaram a surgir, e a mídia começou a publicar notícias positivas sobre o seu legado nessas comunidades, após a implantação das Unidades de Polícia Pacificadora.

Um trecho da reportagem com o título, "Favelas pacificadas preparam a virada da paz" destaca a importância da pacificação para a comunidade. A reportagem noticia que, pela primeira vez em 30 anos, os moradores das comunidades pacificadas passaram o ano novo com segurança.

No Morro da Babilônia, no Leme, os moradores preparam uma recepção especial para um grupo de turistas que terá o privilégio de ver a tradicional queima de fogos da Praia de Copacabana de um ponto inusitado: a 235 metros de altura.

Pode-se aferir que a segurança nas comunidades pacificadas começa a gerar perspectivas de negócios envolvendo a atividade turística.

A reportagem apresentada prospecta o início de uma atividade turística e demonstra, também, a prática da hospitalidade para com os visitantes. De antemão, pode-se perceber que a vivência da hospitalidade ainda se mistura muito com as questões familiares. No trecho analisado, pode-se verificar a hospitalidade pública proposta por Camargo (2004, p.54), que a defende como o "direito de ir-e-vir e, em consequência, de ser atendido sem suas expectativas de interação humana".

Neste sentido verifica-se que o morador da comunidade analisada em questão vê com "bons olhos" a importância do turista para o crescimento econômico da sua comunidade. 
Outro trecho da mesma reportagem mostra claramente que a população local estava interessada no desenvolvimento turístico da comunidade. A preocupação dos moradores é tão grande que Carlos Pereira, o Palu, vice-presidente da associação de moradores declarou que "vamos reunir no máximo 40 pessoas nessa primeira experiência, para que tudo dê certinho". Ainda nesse trecho, Palu revela que, "quando havia guerra entre traficantes, eu e minha família chegávamos a dormir durante dias seguidos no banheiro de casa".

O envolvimento da comunidade com a Unidade de Polícia Pacificadora ocorreu de forma espontânea em algumas favelas. No morro da Babilônia, por exemplo, a capitã Priscila (carioca de Laranjeiras e torcedora do Flamengo) iniciou um trabalho para consultar os moradores sobre a distribuição de brinquedos. A reportagem aponta ainda que "essa comunidade é especial por ter um potencial turístico que precisa ser explorado, afinal é Pão de Açúcar de um lado e Corcovado do outro".

A reportagem aponta ainda que "os Moradores do Morro da Babilônia, no Leme, serão os primeiros a participar do 'Albergue o Seu Gringo', projeto que prevê a hospedagem de baixo custo em áreas pacificadas". Visto isso, com apenas um ano de implantação da Unidade de Polícia Pacificadora a comunidade já começa a colher frutos da atividade turística.

A mesma notícia ainda traz elementos que podemos caracterizar como hospitalidade urbana proposta por Grinover (2007), no trecho "para o presidente da associação de moradores, José Mário Hilário, 49, a pouca iluminação pública, a falta de água e os 114 barracos de madeira são entrave para o desenvolvimento econômico". Percebe-se neste trecho que a falta de infraestrutura é um componente importante para que a localidade seja hospitaleira, de acordo com o autor já citado nesse parágrafo. Para ele esses componentes fazem parte de um conjunto de "serviços que estão presentes na cidade, devendo proporcionar igualdade aos usuários urbanos" (p.135).

Ainda no aspecto referente à hospitalidade segue o último trecho da reportagem.

Como a área está pacificada, chegou o momento de criar um novo modelo econômico para garantir essa vitória", analisa o guia de turismo Wágner Medeiros, autor do projeto. O sistema de hospedagem é o 'bed and breakfast' (cama e café da manhã). O visitante se hospeda na casa de uma família local, conhece a cidade e paga menos.

Fica claro a questão proposta pelo autor da acessibilidade socioeconômica. Neste sentido Grinover leva em consideração "a distribuição de renda" (p.135). Este tipo de projeto dentro das comunidades possibilita esta prática.

A hospitalidade, ainda não se constituía tema central da mídia. Entretanto, após analisar as reportagens, é possível perceber esta prática. Com o título "Pavão- 
A segurança como elemento da hospitalidade: a presença das Unidades de Polícia Pacificadora como elemento facilitador do desenvolvimento do turismo nas favelas do Rio de Janeiro (RJ)

Pavãozinho e Cantagalo receberão visitas guiadas", ainda em 2009, mais uma vez as comunidades analisadas estão presentes na mídia.

No trecho "mais do que fazer obras estruturais, queremos levar dignidade e cidadania a essas comunidades" nota-se novamente a questão da falta da infraestrutura, que para o autor, já citado nesta seção, constitui componente fundamental para a hospitalidade urbana, no que se refere à acessibilidade.

O legado da atividade turística já pode ser percebido nesta reportagem, cuja Figura 1 abaixo demonstra esta realidade.

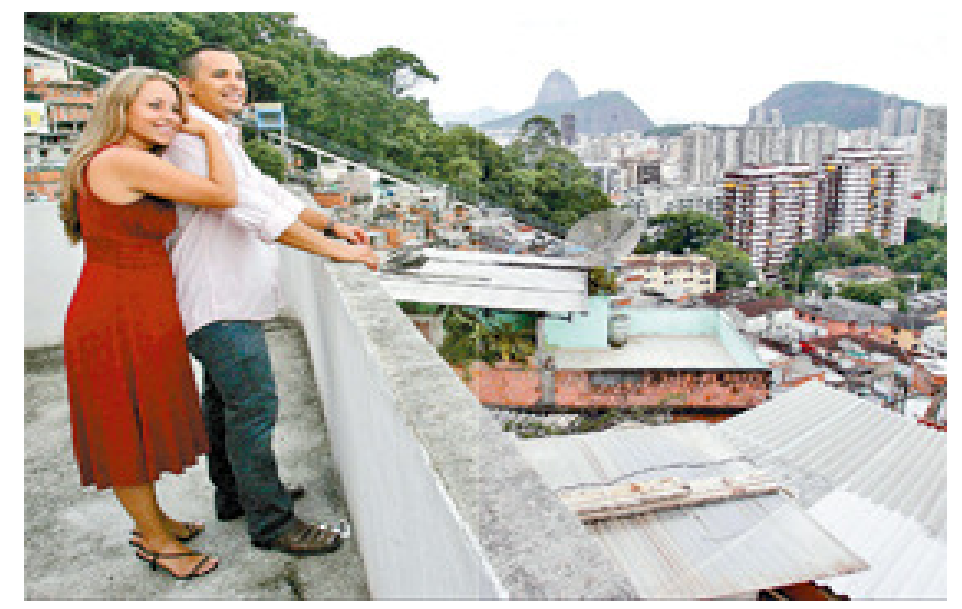

Figura 1: Flávio e Ideni pretendem faturar com o Réveillon no Dona Marta. Fonte: O Dia 29/11/2009. Figure 1: Flavio and Ideni intend to cash in New Year's Eve in the Dona Marta. Source: Journal "O Dia" 29/11/2009.

Uma manchete do site G1 de 23/12/2009 informa que "Cabral inaugura unidade policial para ocupar 2 favelas", novamente revela a questão da acessibilidade socioeconômica proposta por Grinover (2007) que leva em conta a distribuição da renda. Pode-se verificar isso no trecho:

O empresário Daniel Plá anunciou que 30 turistas australianos, franceses e italianos já fizeram reservas para o evento "Réveillon na Laje 2010". Eles assistirão a virada do ano no morro com vista para os fogos de Copacabana. "Toda a renda será revertida para os moradores", declarou o empresário".

Além da questão da expansão da Unidade de Polícia Pacificadora o ano de 2009, serviu para mostrar que os aspectos referentes à hospitalidade urbana, estudada por Grinover (2007) são percebidos na questão da acessibilidade econômica. Os 
aspectos referente hospitalidade comercial foi apresentado como fator fundamental no desenvolvimento da atividade turística das favelas analisadas neste período.

\section{0: Consolidação}

O ano de 2010 serviu para mostrar que a sociedade do Rio de Janeiro, vivenciava um novo momento. As reportagens aduzidas aqui refletem uma nova cidade, ou em contraponto com Ventura (1994), uma única cidade. O autor, ao propor na sua obra "Cidade Partida" que a cidade do Rio de Janeiro se configurava em duas por conta da rede de violência nas comunidades cariocas, não imaginava que a situação das próximas décadas seria diferente.

Em 14 de janeiro de 2010, inicia-se uma nova fase para os moradores do moro dos Tabajaras - Cabritos . Com a proposta inicial de atender três mil moradores, o principal foco do programa da Unidade de Polícia Pacificadora dialoga, de forma satisfatória, com os conceitos apresentados no referencial teórico do presente trabaIho, em especial com o autor Grinover (2007). Ao estabelecer em seu estudo a proposta da acessibilidade como uma forma de hospitalidade, o autor deixa claro que a questão da segurança é um dos pontos para o acontecimento do fenômeno.

A reportagem, além de apontar a segurança como principal questão, ressalta a importância de outros serviços básicos. O trecho da matéria apresenta este fato posto pela comunidade, o comerciante Reinaldo revela que "também espera a entrada dos serviços públicos na comunidade", este fragmento da reportagem mostra mais uma vez a questão da acessibilidade proposta por Grinover (2007), neste sentido está se referindo a acessibilidade aos serviços públicos que para o autor estão descritos nas características da infraestrutura que compõe um dos aspectos da acessibilidade, na definição da hospitalidade urbana.

Além do aspecto referente à hospitalidade urbana, o trecho abaixo apresenta características que fazem menção ao campo da hospitalidade doméstica também conceituada no presente trabalho.

Rosana, que namora há 10 anos um policial militar, está na corporação há 12 . Segundo ela, a receptividade dos moradores a ela é alta. "Ela relatou que uma criança já a convidou para jogar vídeo game em casa e que outra, vendo que ela estava com calor durante a solenidade de inauguração da UPP, Ihe trouxe um copo de água".

Neste sentido, o trecho acima ao mencionar que a "receptividade dos moradores é alta" dialoga com a teoria do autor Camargo (2004), que propõe a hospitalidade doméstica como um ato voluntário. Para isso, o autor estuda os fenômenos em várias frentes. Para tratar da hospitalidade doméstica o autor utiliza o termo "receber domés- 
A segurança como elemento da hospitalidade: a presença das Unidades de Polícia Pacificadora como elemento facilitador do desenvolvimento do turismo nas favelas do Rio de Janeiro (RJ)

tico", categoria que trata das questões "sociológicas, psicológicas e antropológicas da hospitalidade" (p.55).

O ano de 2010 foi o ano da consolidação das Unidades de Polícia Pacificadora. Pouco mais de um ano após a instalação da primeira Unidade de Polícia Pacificadora moro Dona Marta, em Botafogo, os moradores começaram a usufruir dos serviços públicos que até então não eram oferecidos. Essa questão trata da infraestrutura das cidades, que como proposto por Grinover (2007) é um dos itens para que o fenômeno da hospitalidade possa ocorrer.

Abaixo é citado um trecho da reportagem que caracteriza o argumento estudado pelo autor:

\begin{abstract}
"Com lâmpadas quebradas ou sem nenhuma iluminação, as favelas do Rio vão ganhar um banho de luz este ano. No Santa Marta, em Botafogo, o objetivo é quintuplicar a precária iluminação. Dezenas de vias não têm sequer uma lâmpada funcionando. Serão instalados 571 pontos de luz em 300 ruas até o fim de janeiro. Hoje, existem só 130. "A iniciativa contribui para o lazer e a segurança pública", diz o subsecretário Alexandre Pinto. Pacificada em dezembro de 2008, a favela vê funcionários da Rioluz instalando equipamentos desde dezembro."
\end{abstract}

O título da reportagem "Depois das UPPs, banho de luz" revela que a infraestrutura é um grande problema para os moradores das comunidades estudadas. Para o atual Secretário de Segurança a iluminação pública é uma questão de "segurança pública" e ainda de lazer. Mas uma vez a hospitalidade urbana dentro da proposta de Grinover (2007) está sendo legitimada.

Como ano da consolidação, 2010 ainda não tinha terminado e os benefícios das Unidades de Polícia Pacificadora já começaram a aparecer. Em quatro de junho do ano, a reportagem "Pacote turístico para conhecer favela é atração no Rio" já anunciava a favela como um produto turístico seguro, apresentando aspectos referentes à hospitalidade urbana e questões referentes à segurança. Neste sentido pode-se compreender a reportagem com aspectos referentes à acessibilidade, desta forma categorizando-a como hospitalidade urbana, segundo o conceito proposto por Grinover (2007).

No final do mesmo mês, com título "Elevadores do Morro do Cantagalo são inaugurados", a reportagem mais uma vez aponta o conceito do autor citado no último parágrafo, como responsável pela hospitalidade. Dentro da categoria acessibilidade, o transporte de elevador deixa a comunidade agora mais acessível (Figura 2) a todos que desejam conhecê-la.

Ainda em 2010, mais precisamente em outubro, a matéria intitulada "Depois das UPPs, favelas ocupadas pelo sabor" apresenta o conceito de hospitalidade dentro da esfera comercial. 


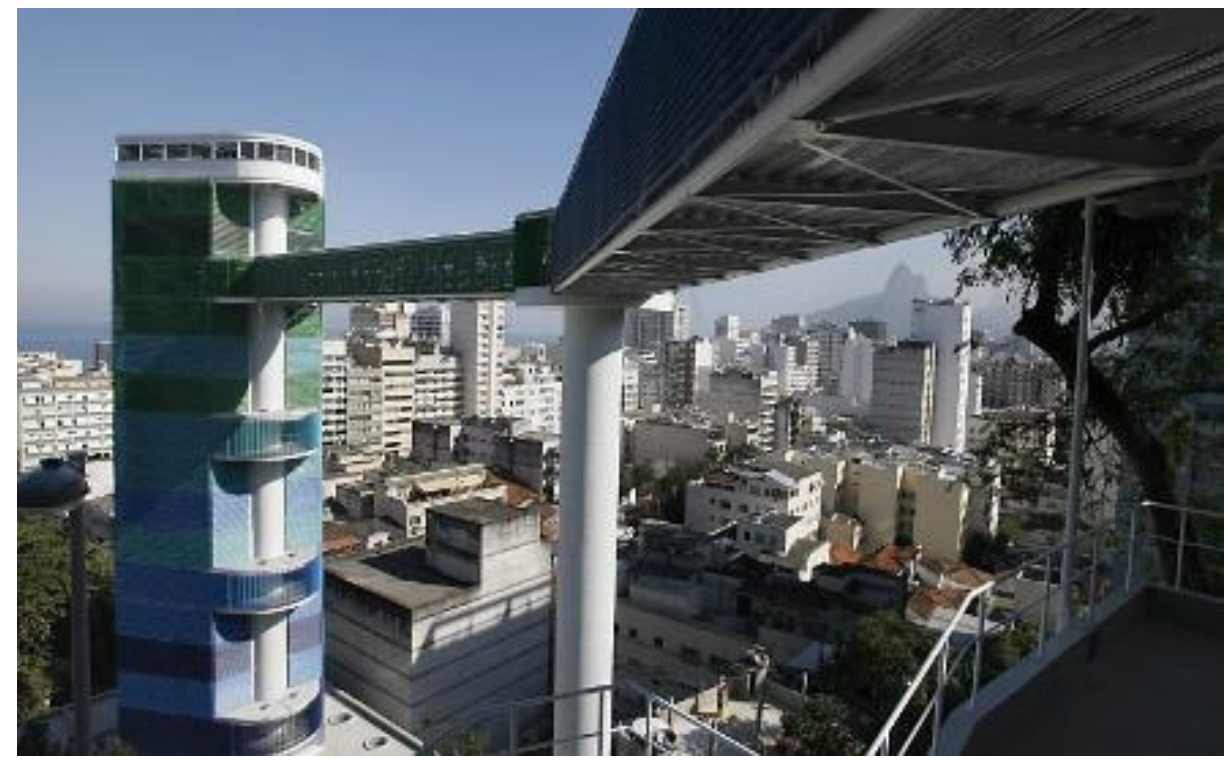

Figura 2: Acessibilidade física - acesso ao Moro do Cantagalo. Fonte: O Extra online, 30/06/2010.

Figure 2: Physical accessibility - access to Morro do Cantagalo. Source: Journal "The Extra online" 30/06/2010.

Nessas pensões, a simplicidade e a simpatia dos proprietários que servem as refeições são melhor entrada" " Turistas já estiveram aqui e preferiram tomar cerveja na laje por conta do visual do porto do Rio, Com a obra, vou ter estrutura para receber mais fregueses - disse" "Ela explicou que, de olha na veia turística que as UPPs representam, já está levando para os profissionais dessas comunidades cursos de formação em gastronomia e manipulação de alimentos.

Neste sentido, ainda que "a simplicidade e a simpatia" gerem sensações de hospitalidade doméstica, a situação ocorre dentro dos domínios comerciais. Desta forma, pode-se categorizar o fenômeno como hospitalidade comercial dentro da proposta de Morrison e Lashley (2003). Para os autores, o cliente necessita utilizar os serviços, sem temer qualquer outra obrigação além da monetária.

O curioso é que a reportagem traz elementos que podem ser percebidos como hospitalidade doméstica. Ao falar que "Turistas já estiveram aqui e preferiram tomar cerveja na laje por conta do visual do porto do Rio" não se pode aferir que se trata de um ato de hospitalidade doméstica, ainda que o serviço seja realizado dentro da residência, há pagamento feito por isso, o que descaracteriza o ato da hospitalidade doméstica proposta por Camargo (2004), que propõe que nesta prática não pode haver nenhum retorno financeiro pela acolhida. 
A segurança como elemento da hospitalidade: a presença das Unidades de Polícia Pacificadora como elemento facilitador do desenvolvimento do turismo nas favelas do Rio de Janeiro (RJ)

\section{1: Panorama e perspectiva}

As reportagens apresentadas aqui são referentes ao ano de 2011, mais precisamente do mês de janeiro até o mês de outubro do ano corrente. Deste modo será apresentado um panorama de como se encontra o processo de pacificação das comunidades tratadas no presente trabalho, e também analisadas algumas perspectivas para o turismo a partir das matérias prospectadas no período.

Com título "Maravilhosa e a mais estilosa do planeta" a matéria sobre o Rio de Janeiro, como palco para Olimpíadas, apresenta uma nova cidade. No trecho "Além de referências a moda, belezas arquitetônicas e naturais, e à simpatia dos moradores, o rigoroso júri da revista destacou a pacificação das comunidades como ponto positivo para eleger a cidade", pode-se perceber que a hospitalidade dos cariocas já é assunto dos jornais e dos turistas estrangeiros.

Em outro trecho da mesma reportagem a turista explana que "Os cariocas são solidários, gentis, educados e estão sempre sorrindo, com ar de felicidade estampado no rosto", justifica Sanhita que ficou muito emocionada com o clima de tranquilidade do moro Dona Marta. A inglesa Kelly Meegan, 47 que estava no mesmo grupo disse que, "estou encantada com a hospitalidade dos cariocas". "Dá vontade de nunca mais ir embora", declarou a designer russa Elena Ablikova, 27, outra turista que acompanha a visita. Todos os aspectos nessa reportagem são referentes à hospitalidade doméstica proposta por Camargo (2004). O que ocorre de fato é uma extrapolação da hospitalidade doméstica para o contexto urbano. O próprio autor apresenta essa problemática nos seus estudos ao revelar que a hospitalidade pública nutre-se da matriz da hospitalidade doméstica. Ao relatar a simpatia dos moradores como algo importante para a prática da atividade turística, percebe-se que a hospitalidade doméstica abrange outros espaços que vão além da configuração doméstica.

O ano de 2011 continuou apresentando perspectivas interessantes para atividade do turismo. Em 30 de janeiro, a matéria "Festas na laje em favelas com UPP fazem sucesso entre turistas no Rio", revela que a segurança, no que diz respeito à infraestrutura, item proposto por Grinover (2006) dentro da categoria acessibilidade, é o que justifica os investimentos para atividade do turismo.

Nesse sentido, pode-se observar que a atividade turística começa a tomar forma dentro das comunidades pacificadas na Zona Sul do Rio de Janeiro. Nota-se tal fenômeno no trecho "A dona do espaço é a simpática aposentada Azelina Viana dos Santos, de 77 anos". O mesmo trecho ressalta ainda que "A laje fica no quarto andar de sua casa e virou ponto turístico. Há dois anos, ela realiza em sua laje um réveillon para turistas e convidados com preços a $\mathrm{R} \$ 250 "$. A reportagem apresenta de forma clara e objetiva o reflexo da presença da Unidade de Polícia Pacificadora dentro das comunidades cariocas.

Ainda no início do ano de 2011 as comunidades Chapéu Mangueira e o Pavão Pavãozinho começaram a usufruir do legado das Unidades de Polícia Pacificadora, o trecho da reportagem abaixo mostra isso claramente. 
Valdinei Medina, dono de um albergue no Chapéu Mangueira, conta que depois da implantação da Unidade de Polícia Pacificadora (UPP) o turismo melhorou muito no local. "Muitos turistas que visitavam a comunidade sentiam a necessidade de um lugar para se hospedar. $O$ albergue foi mais uma necessidade. Hoje, um albergue em qualquer comunidade pacificada vai ser bom pra todo mundo", disse. "Para o australiano Kent Louis, que estuda português, ficar na comunidade é essencial. "Eu gosto de morar aqui por que eu posso falar com brasileiros. É uma comunidade, uma família", contou o turista.

A reportagem mostra um crescimento da atividade do turismo no setor de hospedagem. Depois da instalação da Unidade de Polícia Pacificadora, os moradores donos dos albergues começaram a ganhar mais dinheiro com a hospedagem de turistas.

O principal aspecto referente à hospitalidade da matéria acima remete à hospitalidade urbana conceituada por Grinover (2007) como a possibilidade de um cidadão local ou turista poder ter acesso ao lugar desejado. Ele propõe que a acessibilidade seja um dos itens necessários para que um local seja considerável hospitaleiro, para isso, o autor revela que "nas cidades adequadamente identificadas o estrangeiro sente-se acolhido, bem recebido, sabe onde tem que ir, encontra o que procura sem perda de tempo" (GRINOVER, 2007, p.126).

Ainda, segundo o autor, a acessibilidade pode ser vista como elemento gerador, como "as possibilidades de acesso dos indivíduos, ou grupos sociais, a certas atividades ou a certos serviços presentes na cidade" (GRINOVER, 2007, p.135).

O trecho da reportagem anteriormente citado também aborda a hospitalidade pela ótica da identidade proposta por Grinover (2007) como um elemento de hospitalidade. Percebe-se, neste caso, que o idioma funciona como um facilitador na comunicação, auxiliando, desta forma que o processo da hospitalidade ocorra. Nestes casos, percebe-se a necessidade de placas indicativas disponibilizadas em mais de um idioma, para garantir também a acessibilidade.

Outro legado da presença da Unidade de Polícia Pacificadora pode ser notado na reportagem de 24 de abril de 2011. Com título "UPPs no Rio abrigam circuito gastronômico" o propósito é divulgar um roteiro gastronômico em oito comunidades pacificadas no Rio de Janeiro. Os donos dos bares não tem nenhum tipo de propaganda paga, tampouco divulgação em redes sociais. A propaganda é a de "boca em boca". O comerciante revela que "a comida é para matar a fome, sem frescura. Paga-se a partir de $R \$ 7$ para comer um prato honesto e bem temperado" diz Romero Alves Moreira, dono do restaurante.

No mesmo mês da reportagem citada no último parágrafo, com o título "O perfil do pequeno empresário que une criatividade e tino comercial para levar turistas à favela Dona Marta, na Zona Sul", a favela Dona Marta mais uma vez ganha destaque na mídia. A matéria aponta aspecto referente à acessibilidade, categoria estuda por Grinover (2007) na hospitalidade urbana. Nota-se isso no trecho "No entanto, depois da instalação de uma 
Unidade de Polícia Pacificadora (UPP), ele viu crescer o número de grupos interessados em percorrer trilhas, comer em botecos e alcançar em segurança o mirante". Outro aspecto referente à hospitalidade urbana na categoria identidade também é demonstrado na reportagem (figura 05). A estátua do cantor Michael Jackson representa a identidade física na categoria proposta acima.

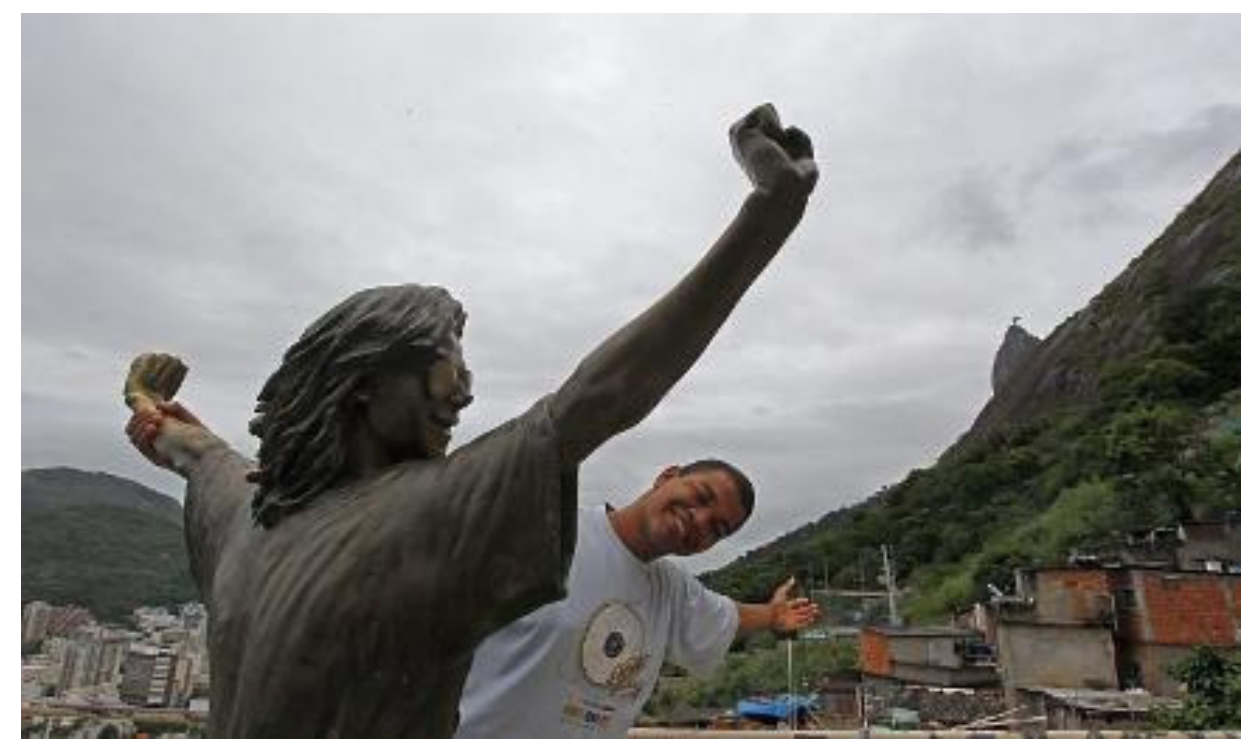

Figura 3: A estátua como identidade cultural da comunidade. Fonte: O Extra online, 30/04/2011.

Figure 3: The statue and cultural identity of the community. Source: Journal "The Extra online", 30/04/2011.

Mais uma vez as favelas do Cantagalo, em Ipanema, e Pavão-Pavãozinho, em Copacabana ganharam destaque na mídia. Em 10 de julho de 2011 com manchete "Comunidades para jovem americano ver" as favelas pacificadas mostraram sua hospitalidade para os turistas. Segue o trecho da reportagem.

"Algo mais consistente do que apenas curiosidade move um novo perfil de turistas estrangeiros que têm visitado favelas cariocas, especialmente as comunidades Cantagalo, em Ipanema, e Pavão e Pavãozinho, em Copacabana, já pacificadas" "Entusiasmados com a visita ao Pavão, Pavãozinho e Cantagalo, alguns deles já deixaram suas impressões por e-mail, que serão lançadas no blog (no ar em agosto), sob os cuidados de um grupo de moradores". "Sem dúvida, foi a minha parte favorita da viagem". "- A favela pode ser debatida sob a ótica de urbanismo, antropologia, ciências sociais e políticas, religião, arquitetura, história e administração de negócios, por exemplo" "para os estudantes americanos, que fizeram um passeio de cinco horas às três áreas pacificadas, onde comeram feijoada, conversaram com moradores, percorre ruas, becos e uma trilha, além de assistir a apresentação de funk. 
Nota-se alguns elementos referentes à hospitalidade. No trecho "percorre ruas, becos e uma trilha" verificam-se aspectos no que tange a hospitalidade urbana na categoria acessibilidade proposto por Grinover (2007), no trecho "assistir a apresentação de funk e samba" percebe-se a categoria identidade da hospitalidade urbana também proposta pelo autor.

"No Chapéu Mangueira, bar ganha prêmio e clientes 'do asfalto"', este é o título da reportagem de 12 de julho de 2011. A reportagem apresenta um aspecto referente ao legado do turismo para a favela do Chapéu Mangueira, no bairro do Leme, como também apresenta categoria de análise da hospitalidade comercial abordado por Morrison e Lashley (2004).

Abaixo trecho da reportagem:

\begin{abstract}
Em abril de 2010, ele assumiu o comando do Bar do David, no Morro Chapéu Mangueira, no bairro do Leme, na Zona Sul do Rio de Janeiro. O bar, que existe há cinco anos, era então apenas uma "birosca", diz. 'Comércio é: qualidade, tratamento e preço'. David aponta que a pacificação da favela e a formalização melhoraram seu negócio: "Eu não tinha o mercado que tenho hoje. O movimento é muito maior, e recebo clientes do asfalto e turistas", ressalta.
\end{abstract}

A categoria da hospitalidade comercial proposta por Morrison e Lashley (2004), ou seja, a prática do bom tratamento em ambientes comerciais, pode ser percebida no trecho "Comércio é: qualidade, tratamento e preço". Os autores afirmam que, para a existência dessa categoria da hospitalidade, a mesma "depende da reciprocidade com base na troca monetária .

\title{
Considerações finais
}

A temática apresentada neste artigo permite a reflexão acerca das possibilidades do turismo na transformação sócio espacial, com melhorias de infraestrutura e maior igualdade de oportunidades para os sujeitos locais, bem como inclusão dos moradores das comunidades, ora assim chamadas, ora chamadas de favelas, na cidade a qual pertencem.

Tal configuração toma maior proporção quando se trata da cidade do Rio de Janeiro, principal destino turístico do país que tinha a violência como principal entrave de desenvolvimento turístico.

A pacificação não somente transmite segurança ao turista da "cidade" como abre as possibilidades de expandir o espaço turístico para a favela, com a oferta tradicional do turismo: atrativos turísticos naturais e culturais, gastronomia, eventos, entre- 
A segurança como elemento da hospitalidade: a presença das Unidades de Polícia Pacificadora como elemento facilitador do desenvolvimento do turismo nas favelas do Rio de Janeiro (RJ)

tenimento, transporte e até mesmo hospedagem. Desse modo, a favela deixa de ser o local exótico a ser visto de dentro dos jeeps e passa a ser um local de experiência turística.

Das 30 de reportagens analisadas para o presente artigo, poucas mostravam, de fato, o interesse da população autóctone para com a hospitalidade nas práticas turísticas. Ainda assim, as matérias discutidas no presente trabalho, conseguiram mostrar as mudanças nas relações de hospitalidade nas atividades turísticas das favelas cariocas após a instalação das Unidades de Polícia Pacificadora.

As análises das reportagens mostram que as comunidades pacificadas querem não só receber bem os turistas, como também poder lucrar com isso. A hospitalidade nessas comunidades acontece de forma muito particular em cada favela. A experiência das práticas de hospitalidade pode ser vivenciada nas comunidades pacificadas, de forma singular. É preciso entender que a favela agora tem, como corrobora Grinover (2006), acessibilidade, legibilidade e identidade.

Nota-se que as favelas cariocas precisam ter a possibilidade de mostrar seu potencial, sem perder sua verdadeira identidade. Com isso, também é importante que os comerciantes sejam hospitaleiros para com os turistas não só nas práticas turísticas. É importante para o desenvolvimento do setor que esta prática ocorra sempre de forma natural, sem vínculo direto com aspecto econômico.

Com a implantação das Unidades de Polícia Pacificadora as reportagens, de uma forma geral, apontaram um indicador favorável para a atividade turística. Neste sentido pode-se pensar que a segurança nas favelas cariocas é um dos principais fatores que contribui para o aumento do turismo na região.

No entanto, cabe salientar que somente a segurança não será suficiente para garantir o desenvolvimento local com inclusão social. Políticas públicas de turismo sérias devem ser tomadas para evitar a especulação imobiliária e para qualificar e profissionalizar a prestação de serviços pela comunidade local.

\section{Referências bibliográficas}

BARDIN, L. Análise de Conteúdo. Lisboa, Portugal: Edições 70, 1977.

BARRETTO, M. Relações entre visitantes e visitados: um retrospecto dos estudos socioantropológicos. Turismo e Análise. São Paulo: ECA/USP. v. 15, n 2, p. Nov. 2004.

BARRETTO, M. Turismo, Cultura e Sociedade. Caxias do Sul, RS: Educs, 2006.

BAUMAN, Z. Vida para consumo: a transformação das pessoas em mercadorias, tradução de Carlos Alberto Medeiros. Rio de Janeiro: Jorge Zahar Ed., 2008. 
BAUMAN, Z. Comunidade: a busca por segurança no mundo atual. Rio de Janeiro: Jorge Zahar Ed., 2003.

CAMARGO, L. O. L. Hospitalidade. São Paulo: Aleph, 2004.

CAMPOS, A. Do quilombo à favela: a produção do "espaço criminalizado" no Rio de Janeiro. Rio de Janeiro: Bertrand Brasil, 2005.

CAMPOS, J. R. V. Introdução ao universo da hospitalidade. Campinas: Papirus, 2005.

DENCKER, A. Métodos e técnicas de pesquisa em turismo. 4. Reimp. São Paulo: Futura, 2001.

FREIRE-MEDEIROS, B. A construção da favela carioca como destino turístico. Rio de Janeiro: CPDOC, 2006.

FREIRE-MEDEIROS, B. Favela e seus trânsitos turísticos. Observatório de Inovação do Turismo, v.2, n.2, p 1-13, 2007.

FREIRE-MEDEIROS, B. O Rio de Janeiro que Hollywood inventou. Rio de Janeiro: Jorge Zahar Ed., 2005.

FREIRE-MEDEIROS, B. Gringo na laje: Produção, circulação e consumo da favela turística. Rio de Janeiro: Editora FGV, 2009.

GRINOVER, L. A Hospitalidade, A cidade e o Turismo. São Paulo: Aleph, 2007.

GRINOVER, L. A hospitalidade urbana: acessibilidade, legibilidade e identidade. Revista Hospitalidade, São Paulo, ano III, N.2, P.29,2. Sem. 2006.

LASHLEY, M.; MORRISON. Em busca da hospitalidade: perspectivas para um mundo globalizado. São Paulo: Manole, 2005.

NIELSEN, C. Turismo e mídia: construção e destruição de destinos turísticos. Tradução de Edite Sciulli. São Paulo: Contexto, 2002.

PLENTZ, R. S. Dialética da hospitalidade: caminhos para a humanização. Caxias do Sul, RS: UCS, 2007.

SILVA, L.D. Por que a impressa "gosta de tragédias? Disponível em < http:// www.unb.br/noticias/unbagencia/artigo.php?id=252>. Acesso em: 07 de set. 2010.

SOUZA, J. S. Favela: alegria e dor na cidade. São Paulo: Ed. Senac,2006.

URRY, J. O Olhar do turista: lazer e viagens nas sociedades contemporâneas. São Paulo: Studio Nobel: SESC, 1996.

ZUENIR, V. A cidade partida. São Paulo: Companhia das Letras, 1994. 
Manoela Carrillo Valduga: Universidade Federal Fluminense, Niterói, RJ, Brasil. Email: manoelavalduga@hotmail.com Link para o currículo Lattes: http://lattes.cnpq.br/1175724748253107

Reginaldo Lima de Moura: Universidade Cândido Mendes, Rio de Janeiro, RJ, Brasil.

Email: reginaldolimauff@yahoo.com.br

Link para o currículo Lattes: http://lattes.cnpq.br/7253396866101012

Data de submissão: 30 de junho de 2012

Data de recebimento de correções: 12 de junho de 2013

Data do aceite: 12 de junho de 2013

Avaliado anonimamente 


\title{
Turismo de base comunitária e desenvolvimento socioespacial: um diálogo possível
}

\author{
Community-based tourism and socio-spatial development: dialogue possible
}

\author{
Alessandra Silva Lobato
}

\section{RESUMO}

O presente artigo tem como objetivo compreender como é possível existir um diálogo entre o turismo de base comunitária e o desenvolvimento socioespacial, no sentido de utilizar estes conceitos na elaboração de projetos voltados ao desenvolvimento do turismo em áreas de comunidades tradicionais. Para alcançar o objetivo foram realizados levantamentos e revisões bibliográficas sobre o tema em questão. Observou-se que o turismo de base comunitária apresenta várias características que se aproximam dos princípios do desenvolvimento socioespacial proposto por Marcelo Lopes de Souza. Destaca-se que o desenvolvimento proposto com o Turismo de Base Comunitária é aquele no qual as comunidades envolvidas devem ser as principais beneficiadas, devendo ter autonomia para decidir sobre as ações voltadas ao turismo. Autonomia, qualidade de vida e justiça social são os parâmetros para se alcançar o desenvolvimento socioespacial. Assim, nota-se que é possível o turismo de base comunitária contribuir com o desenvolvimento de comunidades tradicionais.

PALAVRAS-CHAVE: Turismo de Base Comunitária; Desenvolvimento Socioespacial; Comunidades.

\section{ABSTRACT}

This article aims to understand how there can be a dialogue between the communitybased tourism and socio-spatial development, in the sense of using these concepts in the development of projects related to the development of tourism in areas of traditional communities. To achieve the goal, surveys and literature reviews were conducted on the related topic. It was observed that the community-based tourism has several characteristics that approximate to the principles of socio-spatial development proposed by Marcelo Lopes de Souza. It is noteworthy that the proposed development with the community-based tourism is one in which the involved communities should be the main benefitted and they should be free to decide on the actions related to tourism. Autonomy, quality of life and social justice are the parameters to achieve the sociospatial development. Thus, it is realized that it is possible to the community-based tourism contribute to the development of traditional communities.

KEYWORDS: Community Based Tourism; Socio-Spatial Development; Communities. 


\section{Introdução}

O presente trabalho pretende contribuir com as discussões sobre o Turismo de Base Comunitária e o Desenvolvimento Socioespacial, haja vista que estes dois conceitos apresentam elementos que permitem a eles uma forma de diálogo, sendo apontados nesta pesquisa teórica como conceitos a serem levados em consideração na elaboração de projetos de desenvolvimento turístico em áreas de comunidades tradicionais.

É fato que o território nacional desde o inicio de sua colonização vem sendo explorado devido a grande disponibilidade de recursos naturais, que são apropriados pelo grande capital e transformados por estes. Ao longo dos séculos percebe-se que 0 surgimento de várias atividades econômicas como a atividade industrial, a agricultura, o turismo entre outras contribuiu para o crescimento econômico do país, no entanto contribui, também, para o processo de degradação ambiental e de exploração de comunidades tradicionais, como pode ser observado no litoral brasileiro e na região amazônica.

Quando se trata do turismo em áreas com presença de comunidades tradicionais, observa-se que a inserção da população local ocorre de maneira bastante precária e com exploração acentuada dos recursos naturais como pode ser constatado em vários trabalhos já publicados sobre o tema, isso caracteriza um turismo de massa, uma forma de fazer turismo no qual não se observa melhorias para as populações locais que em vários momentos são vistas como os "atrativos" dessa atividade que também é produtora de espaço. Estudos mostram que as comunidades locais pouco participam do Planejamento Territorial, principalmente, no que se refere às ações voltadas ao turismo, como pode ser constatado nos trabalho de Santana (2009) e Rosário (2010).

Tendo em vista as dificuldades e problemas existentes em comunidades tradicionais como, por exemplo, a precariedade de acesso a transporte, saúde, educação entre outros, aponta-se nesta pesquisa o Turismo de Base Comunitária como um possível vetor de desenvolvimento. Este desenvolvimento envolve não somente a dimensão econômica, mas também, cultural, política e social. É o desenvolvimento que possa contribuir com a amenização de alguns dos problemas citados.

Assim o objetivo do artigo é compreender como é possível existir um diálogo entre Turismo de Base Comunitária e Desenvolvimento Socioespacial, no sentido de utilizar estes conceitos na elaboração de projetos voltados ao desenvolvimento do turismo em áreas de comunidades tradicionais.

Para o desenvolvimento da pesquisa foram realizados levantamentos e revisões bibliográficas sobre o TBC e o desenvolvimento Socioespacial, utilizando-se os conceitos dos principais autores que contribuíram com as discussões sobre TBC: Irving (2009), Bursztyn, Bartholo; Delamaro (2009), Rita Cruz (2009), Coriolano (2009), Sansolo (2009), Bartholo (2009), Zechener et al (2008), Zaoual (2000), e sobre o conceito de Desenvolvimento Socioespacial utilizou-se os trabalhos de Souza (1996; 1997; 
$2001 ; 2006)$.

O artigo encontra-se estruturado em 3 partes, na primeira discute-se o processo de construção do turismo comunitário e quais suas bases teórico-conceituais, no segundo discute-se sobre o conceito de desenvolvimento Socioespacial e por fim como os conceitos de TBC e desenvolvimento Socioespacial dialogam.

\section{A construção do Turismo de Base Comunitária e suas bases teórico-conceituais}

O Turismo de Base Comunitária surgiu com este nome no ano de 2003, durante a realização do $1^{\circ}$ Fórum Internacional de Turismo Solidário, que ocorreu na cidade de Marseille na França, e que teve outras edições, uma no ano de 2006 na cidade Chiapas no México que foi o 2 o Fórum, e outra no ano de 2008, na cidade de Bamako no Mali que foi o $3^{\circ}$ Fórum. No Brasil o turismo comunitário surge em um primeiro momento, como tema de diálogo científico a partir do I Encontro Nacional de Turismo de Base Local (ENTBL), realizado em São Paulo, no ano 1997. Num segundo momento, acrescentou-se ao debate científico a participação de movimentos sociais na ocasião do I Seminário Internacional de Turismo Sustentável, realizado em Fortaleza, no ano de 2003 de acordo com Zechener et al (2008).

As discussões sobre essa forma de turismo surgiram em decorrência de múltiplos fatores, dentre eles destacam-se a crise socioambiental contemporânea, que está diretamente relacionada à ideologia desenvolvimentista, a qual associa o desenvolvimento ao crescimento econômico e ao progresso técnico-científico como apontam Araujo e Gelbcke (2008), nas últimas décadas o setor do turismo conheceu uma rápida expansão global, chegando a ser considerada uma das maiores atividades dentro da economia mundial. "A ampliação geográfica do setor respondeu a processos distintos como: réplica às novas demandas de mercado; como estratégia de desenvolvimento local; e, sobretudo, para liberar e integrar mercados regionais" (MOLINA, 2003 apud ARAUJO; GELBCKE, 2008, p.8).

Outro fator que contribuiu para a ampliação das discussões sobre outra forma de turismo que causasse menos impactos que a atual, foi à massificação deste setor enquanto atividade econômica em nível planetário, principalmente de determinados segmentos deste, no Brasil, por exemplo, o turismo de "sol e praia" é um dos que mais se desenvolve e movimenta capital, isto é possível em parte, devido à localização do território nacional. O Brasil possui um litoral bastante extenso, isso propicia o desenvolvimento deste segmento, principalmente na região nordeste, no entanto a inserção da população local ainda ocorre de maneira bastante precária, apesar disto é nesta região que o turismo comunitário tem ganhado mais força e adeptos, o turismo comunitário aparece neste contexto como uma alternativa ao turismo de massa. "Ele representa uma estratégia de desenvolvimento para grupos com menores condições de ingressarem de maneira autônoma (self-realiance) na cadeia produtiva do turismo" (ARAUJO; GELBCKE, 2008, p.10). 
No TBC buscam-se estratégias de desenvolvimento para comunidades, este desenvolvimento não é aquele voltado apenas à dimensão econômica, mais sim social. Comunidades são entendidas neste trabalho como grupos sociais que residem em pequeno espaço geográfico, cuja integração de pessoas entre si e dessas com o lugar é capaz de criar identidades muito fortes que tanto os habitantes como o lugar são identificados como comunidades (CORIOLANO, 2009).

Antonio Diegues (2002) ao explicar o sentido de comunidade aponta que estas são possuidoras de culturas tradicionais sendo o padrão tradicional e o modo de vida critérios de fundamental importância para a definição de comunidade.

Estão associadas a modos de produção pré-capitalistas, próprios de sociedades em que o trabalho ainda não se tornou mercadoria, onde há grande dependência do mercado já existente, mas não é total. Essas sociedades desenvolveram formas peculiares de manejo dos recursos naturais que não visam diretamente o lucro, mas a reprodução social e cultural; como também percepções e representações em relação ao mundo natural marcadas pela ideia de associação com a natureza e dependência de seus ciclos (DIEGUES, 2002, p.83).

Na sociedade moderna, as comunidades significam uma critica ao modo de vida moderno, que produziu/produz profundas desigualdades sociais, "a comunidade expressa organização coletiva de reivindicações para a busca de melhores condições de vida, de luta para a sociedade pautada na justiça e na igualdade de direitos" (CORIOLANO, 2009, p.43), isso demonstra que viver em comunidade requer igualdade para que a liberdade possa se concretizar.

Para Adrião (2011) as comunidades se apresentam enquanto organização humana e social, que possuem vida própria, está para além da casa, do ser humano, elas partilham um interesse comum. As comunidades, na sociedade moderna tendem a se organizar coletivamente para reivindicar a busca de melhores condições de vida, tudo isso baseada numa sociedade pautada na justiça e na igualdade de direitos.

Mielke (2009) mostra que o desenvolvimento em comunidades, é uma atividade muito interessante devido a vários fatores, dentre eles destacam-se as possibilidades de criações e estruturações de novos roteiros e destinos turísticos de pequeno porte , que podem contribuir como uma opção complementar de geração de divisas.

As comunidades devem ser as principais beneficiadas com a atividade turística, pois o que se percebe é que a atividade turística do tipo massificada tem gerado graves problemas sociais e econômicos, como por exemplo, ociosidade de mão de obra local durante a maior parte do ano, elevação anormal de preços, inserção precária da mão de obra local, especulação imobiliária, segregação entre habitantes locais e visitantes, trânsito, violência, prostituição, vulgarização da autenticidade e problemas ambientais: poluição e devastação de ecossistemas. Tendo em vista estas considerações aponta-se o Turismo de Base Comunitária como uma alternativa, essa forma de turismo 
tende a ser aquele tipo de turismo que, em tese, favorece a coesão e o laço social e o sentido coletivo de vida em sociedade, e que por esta via, promove a qualidade de vida, o sentido de inclusão, a valorização da cultura local e o sentimento de pertencimento. Este tipo de turismo representa, portanto, a interpretação "local" do turismo, frente às projeções de demandas e de cenários do grupo social do destino, tendo como pano de fundo a dinâmica do mundo globalizado, mas não as imposições da globalização (IRVING, 2009, p.113).

Com isso observa-se que o TBC, implica não apenas a interpretação simplista e estereotipada de um grupo social desfavorecido que recebe investimentos e pessoas curiosas e ávidas pelo exotismo em seu convívio cotidiano, para o aumento de sua renda e melhoria social. Este turismo significa encontro e oportunidade de experiência compartilhada entre os visitantes e os visitados (IRVING, 2009).

A autora aponta que uma das premissas fundamentais do TBC é a base endógena da iniciativa, pois se a "iniciativa não tiver motivação endógena e expressar o desejo dos grupos sociais locais, ela certamente não atenderá às demandas de desenvolvimento local e nem contribuirá para o protagonismo social, condição essencial para este tipo de turismo" (IRVING, 2009, p.114). Além da iniciativa endógena para projetos desta natureza, a participação local deve ocorrer em outros momentos do projeto turístico como no processo de planejamento, implementação e avaliação do mesmo, tal ação representa um elemento eficaz para a sustentabilidade das iniciativas propostas e para a garantia ética da conservação do patrimônio.

Quando a autora destaca que esta forma de turismo favorece a valorização cultural local, isso evidencia a própria valorização do patrimônio cultural do lugar, estes patrimônios culturais devem ser entendidos mais adequadamente se situados como elementos mediadores entre diversos domínios sociais e simbolicamente construídos, estabelecendo pontes e cercas entre categorias que são cruciais, tais como passado e presente, deuses e homens, mortos e vivos, nacionais e estrangeiros, ricos e pobres (GONÇALVES, 2005 apud PAES, 2010, p.165).

Deve-se de acordo com Matias (2009) identificar e incentivar as formas de turismo que tenham com prioridade o desenvolvimento do lugar, este desenvolvimento deve estar em bases equitativas, que representem alternativas adequadas para a preservação cultural das comunidades locais e de seu ambiente, renegando-se assim as estratégias de mercantilização da cultura.

Percebe-se que nos últimos anos o turismo tem ganhado maior visibilidade a nível nacional, especialmente, quando nos referimos a pequenos agricultores familiares e pequenos proprietários rurais que estão vendo no turismo uma alternativa de melhoria de vida. Órgãos como Ministério do Desenvolvimento Agrário (MDA), Ministério do Meio Ambiente (MMA) e Ministério do Turismo (MTUR) estão criando políticas públicas, que tem beneficiado estas populações. 
Sampaio (2005) aponta que o turismo comunitário é uma estratégia para que populações tradicionais sejam protagonistas de seus modos de vida próprios, tornando -se uma alternativa possível ao modo de vida materialista-consumista no qual se vive. Zechener et al (2008) destacam que o turismo comunitário vale-se da vitrine que representa o setor de turismo recentemente, o que significa que esta forma de turismo se apropria da racionalidade instrumental, porém não a de cálculo de consequências meramente individuais, mas sim a de ganhos coletivos, ganhos que possam ser divididos entre aqueles que fazem parte daquela comunidade.

O TBC "busca respeitar as heranças culturais e as tradições locais, podendo servir de veiculo para revigorá-las e mesmo resgatá-las. Tem centralidade em sua estruturação o estabelecimento de uma relação dialogal e interativa entre visitantes e visitados" (BURSZTYN et al., 2009, p.88).

Esta modalidade de turismo é um modelo alternativo de desenvolvimento turístico, deve estar baseado em vários princípios, dentre eles estão a autogestão, o associativismo/cooperativismo, pressupõe, também, a valorização cultural daquele lugar, além disso, vê as comunidades locais como principais beneficiados, com o desenvolvimento da atividade turística (MTur, 2008).

O turismo comunitário "busca-se contrapor ao turismo massificado, requerendo menor densidade de infraestrutura e serviços e busca valorizar uma vinculação situada nos ambientes naturais e na cultura de cada lugar" (BURSZTYN et al., 2009, p.88). Para os autores este turismo alternativo busca, "um outro modo de visita e hospitalidade, diferenciado em relação ao turismo massificado, ainda que porventura se dirija a um mesmo destino" (p.88), neste sentido o TBC visa algo que o diferencia das relações que são estabelecidas no turismo de massa.

Segundo Bartholo (2009) a ida de um turista de base comunitária a um local pode ser comparada a ida de um viajante a um sítio, pois existe neste encontro com o outro uma possibilidade de dividir a experiência de sentido que ali se dá, pois os sítios são como comunidades de sentido que

impregnam o conjunto das dimensões dos territórios da vida: com relação ao tempo, à natureza, ao espaço, ao habitat, à arquitetura, ao vestuário, às técnicas, ao saber-fazer, ao dinheiro, ao empreendedorismo etc. Antes de se materializar nos feitos e gestos dos atores ou em qualquer outra materialidade visível a olho nu, os sítios são entidades imateriais fornecedoras de balizamentos para os indivíduos e organizações sociais" (ZAOUAL, 2000 apud BARTHOLO, 2009, p.52).

No trabalho de Zaoual (2000), é notável que o autor faz referências aos trabaIhos de Martin Heidegger apontando que o sítio é capaz de reunir em sí o mais elevado e o mais externo, que ao reunir penetra e perpassa todo o resto. Em outro trabalho de Zaoual é possível observar como a teoria dos sítios está relacionada a vários fatores como crenças, conhecimentos e comportamentos. 
o sítio é uma cosmovisão, um espaço de crenças partilhadas que define o real, em um dado momento, bem como as concepções e as práticas de seus atores. O conceito de sítio articula assim suas crenças, seus conhecimentos e seus comportamentos. O que dá lugar a uma pedagogia de três caixas. Um sítio é, antes de tudo, uma entidade imaterial, invisível (ZAOUAL, 2009, p.65).

Estas considerações vão ao encontro do que se propõe o turismo comunitário, pois o sentido de proximidade com o outro se expressa através das suas crenças, conhecimentos e comportamentos. É algo que será observado por aqueles que fazem este turismo alternativo, quem vivencia esse turismo busca compreender ou pelo menos tenta entender mesmo que de uma maneira involuntária o que para o outro é o seu próprio cotidiano, é a sua relação com aquele espaço.

Os sítios de pertencimentos são construídos pela comunidade e é onde se observa o lugar do encontro, o sítio, onde se recebe e é recebido, este lugar possui uma especialidade real, histórica e culturalmente construída. São diferentes dos espaços turísticos produzidos, os sítios para serem percebidos como turísticos, devem ser antes de tudo reconhecidos pelos próprios residentes; deve haver uma autoidentificação típica do sentido de comunidade. O sítio é cheio de significados próprios, que são valorizados pela comunidade, e que se coloca disponível para o intercâmbio.

De acordo com Lima et al. (2009) a teoria dos sítios tem por horizonte a constituição de novos saberes e formas de ação que considerem as contingências qualitativas de cada meio, a diversidade dos contextos da ação dos agentes econômicos, contrapondo-se dessa forma ao reino da produtividade, da concorrência irrestrita, da quantidade e das certezas do passado. O sítio é, portanto, "o lugar onde as crenças e práticas se ajustam às circunstâncias locais e contrariam a lógica exclusiva do mercado" (LIMA et al., 2009, p.10).

Bartholo (2009) fala dos tipos de relações que o ser humano desenvolve com o outro. Neste ponto do trabalho é importante ressaltar estas relações, porque elas são diferentes e se reproduzem nas atividades desenvolvidas pelo homem, é o caso do turismo, para tratar sobre isso o autor utilizou os trabalhos Fragmentos Autobiográficos e Eu Tu de Martin Buber. "Para Buber, a pessoa da relação Eu-Tu é o suporte relacional que permite fazer da alteridade uma presença, numa possibilidade relacional que se estende para além do campo do inter-humano" (p. 49), isso simboliza a proximidade entre os seres, no turismo comunitário é este tipo de relação que predomina, ela pressupõe o encontro face a face.

Diferente das relações do tipo "Eu-Tu" Buber apresenta as relações do tipo "Eu -Isso" que representam relações de apropriação utilitária no qual se busca uma mediação por outros interesses que não são apenas os das relações. Bartholo (2009) interpretando a proposta de Buber sobre este último tipo de relação apresentada mostra que 
Nela não há lugar para proximidades vinculantes, que lhe permanecem uma exterioridade. Ela não conhece encontros face a face. Seu operar é uma repetida requisição da disponibilidade dos entes para serem usados como objetos de conhecimento, instrumentalização e controle (p.53).

É possível notar que este tipo de relação é visível no turismo massificado, em outra parte de seu trabalho o autor destaca a necessidade de se buscar cada vez mais as relações do tipo Eu-Tu, pois estas relações estabelecem "sempre um acontecimento surpreendente e incontrolável, que escapa ao determinismo dos planejamentos e projetações" (BUBER, 1991 apud BARTHOLO, 2009, p.52), percebe-se com isso as relações quando mantidas com seu sítio simbólico de pertencimento lhes são identitárias.

O TBC tem como alguns atrativos a disponibilização do lugar, das relações do espaço vivido, como as relações de convivencialidade, que é "uma relação social que se interessa pelo outro, pelo diferente, pela alteridade, pela autenticidade, respeitando a simplicidade das comunidades tradicionais, suas rotinas, seu jeito de falar, cantar, dançar, comer, entre outros" (ZECHENER et al., 2008, p.7), algo completamente diferente do turismo convencional, que é criador de espaços de exclusão/segregação tanto para o turista quanto para os moradores. Outro atrativo apontado pelos autores é o de vivenciar a dimensão espaço-tempo que é regulada pelo sol, pela lua e pelas chuvas. O tempo é regulado pelo ciclo natural de um modo de vida mais conectado com a natureza.

Ao criar espaços de encontro o TBC, permite o compartilhamento do cotidiano, do lazer, da religiosidade, dentre outras atividades, isso permite que as relações interpessoais sejam favorecidas. As características apresentadas ao longo desta sessão demonstram que esta forma de fazer turismo prioriza o lugar, a conservação ambiental e a valorização da identidade cultural, aspectos pouco priorizados em uma sociedade que vê a natureza e o ser humano apenas como uma mercadoria e mão de obra barata, respectivamente, sobretudo, quando a atividade turística ocorre em comunidades que não participaram do planejamento e gestão desta atividade em seus espaços.

Por isso deve-se pensar no TBC como uma atividade que possa contribuir com o desenvolvimento, não somente no sentido econômico, mas também social, que valorize a cultura local, a autonomia do ser humano, para entender melhor isso na seção seguinte será discutido o conceito de desenvolvimento socioespacial proposto por Marcelo Lopes de Souza.

\section{Sobre o conceito de Desenvolvimento Socioespacial}

Cruz (2009) mostra que o crescimento econômico tem sido considerado por muitos um pressuposto imprescindível para o desenvolvimento, já que a população mundial cresce e, consequentemente, as demandas por bens materiais e imateriais. Ainda é visível a ideia de desenvolvimento associado ao aspecto econômico, no qual 
são levados em consideração diversos indicadores como o Produto Interno Bruto, Produto Nacional Bruto, o PIB per capita, indicadores que são apenas quantitativos e não representam o real desenvolvimento.

Souza (1997) mostra que o desenvolvimento não deve ser pensado/entendido como sinônimo de desenvolvimento econômico, pois observa-se que o "desenvolvimento estritamente econômico pode ocorrer sem que, automática ou forçosamente haja melhoria do quadro de concentração de renda ou dos indicadores sociais" (p.18).

Observa-se em muitas situações que a atividade turística vem acompanhada de equipamentos tecnológicos que provocam intensa liberação de mão de obra, gerando assim aumento do desemprego ou inserindo de maneira precária as populações locais, isso ocorre devido a vários fatores, dentre eles destacam-se a escassa ou inexistente participação popular no planejamento e gestão de empreendimentos ligados ao setor turístico, como já mencionado anteriormente. Por isso "o desenvolvimento deve ser encarado como um processo complexo de mudanças e transformações de ordem econômica, política e, principalmente humana e social" (OLIVEIRA, 2002, p.40).

Neste sentido, busca-se compreender o turismo, em especial o turismo de Base Comunitária, como uma atividade indutora de desenvolvimento em comunidades. Esse desenvolvimento seria abrangente, correspondendo ao desenvolvimento socioespacial proposto por SOUZA (1997), que deve ser compreendido

Como um processo de superação de problemas e conquistas de condições (culturais, técnico-tecnológicas, político-institucionais, espaçoterritoriais) propiciadoras de maior felicidade individual e coletiva, o desenvolvimento exige a consideração simultânea das diversas dimensões constituintes das relações sociais (cultura, economia, política) e, também, do espaço natural e social (p.19).

É necessário ressaltar que conceber esta forma de desenvolvimento não é tarefa fácil, mas considera-se que esta é a que mais se aproxima da realidade e dos benefícios que um real desenvolvimento pode promover a um local, pois levar em consideração apenas a dimensão econômica é não observar a diversidade das relações sociais que existem no espaço.

Neste contexto faz-se indispensável mostrar que o espaço é um produto social como aponta Souza (1996; 1997), pois

o espaço é primeiramente, ou em sua dimensão material e objetiva, um produto da transformação da natureza (do espaço natural: solo, rio, etc.) pelo trabalho social. Palco das relações sociais, o espaço é, portanto, um palco verdadeiramente construído, modelado, embora em graus muito variados de intervenção e alteração pelo homem (SOUZA, 1997, p.10). 
Este espaço consegue ao mesmo tempo ser suporte e condicionador, é suporte quando nos referimos à vida em sociedade, e condicionador quando nos referimos aos projetos humanos. Este espaço envolve também, outras dimensões como o afetivo e o simbólico. E para a organização política este espaço é visto como uma arena de luta e uma fonte de recursos.

Por isso o desenvolvimento é necessariamente socioespacial, ou seja, da sociedade e do espaço: tão tola quanto a crença de se transformar substantivamente as relações sociais apenas por meio de intervenções no espaço ("fetichismo espacial" tipificado por centros urbanistas) é a negligência para com o fato de que a mudança social demanda, concomitantemente (mesmo que nem sempre isso ocorra), a mudança da organização espacial que amparava as velhas relações sociais (SOUZA, 1996, p.7).

Pensar numa teoria do desenvolvimento socioespacial envolve uma série de parcialidades que precisam ser superadas. É imprescindível compreender que a sociedade é como um todo indivisível, constituído por várias dimensões: sociais, espaciais, históricas, e que estas se encontram interligadas.

O desenvolvimento deve vir acompanhado por mudança social positiva como aponta Souza (2001) que contemple não apenas as relações sociais, mas também e de forma igualitária a espacialidade, "desenvolvimento pressupões mudança, transformação- e uma transformação positiva, desejada ou desejável” (p.1). Portanto apenas é possível falar em desenvolvimento socioespacial quando se constata uma melhoria da qualidade de vida e um aumento da justiça social, ambos estão subordinados a autonomia, esta é apontada por Souza $(1997 ; 2001$; 2006) como um principio que demanda aspectos tanto do plano interno (como por exemplo, a chance de participação na tomada de decisões importantes para a vida social, isso deveria ocorrer de forma igualitária), quanto do plano externo (a autonomia do outro e os interesses reais), conforme o principio da não intervenção.

Para ele a autonomia pode ter duas faces a individual e a coletiva, a autonomia individual corresponde

a capacidade de cada individuo de estabelecer metas para si próprio com lucidez, persegui-las com a máxima liberdade possível e refletir criticamente sobre a sua situação e sobre as informações de que dispõe, pressupõe não apenas condições favoráveis, sob o ângulo psicológico e intelectual, mas também instituições sociais que garantem uma igualdade efetiva de oportunidades para todos os indivíduos (SOUZA, 2001, p.64).

A autonomia coletiva corresponde 
Não somente instituições sociais que garantam a justiça, a liberdade e a possibilidade do pensamento crítico, mas também a constante formação de indivíduos lúcidos e críticos, dispostos a encarnar e defender estas instituições (SOUZA, 2001, p.64 e 65).

Souza (2001) ressalta que a autonomia possui tanto um valor instrumental quanto um valor substantivo ou intrínseco. O valor instrumental corresponde à importância da liberdade para se fazerem coisas e de se proteger de ações nocivas, enquanto isso o valor intrínseco corresponde à fruição da liberdade efetiva vista como um bem em sí mesma.

Analisando trabalhos de Cornelius Castoriadis, Souza (2006) aponta ainda a necessidade de se fazer à diferença entre autonomia em sentido forte e autonomia em sentido fraco.

\begin{abstract}
Em "sentido forte" a referencia à autonomia equivaleria a ater-se a um horizonte de pensamento e ação: o projeto de construção de uma sociedade basicamente autônoma. Já o "sentido fraco" refere-se à necessidade de valorizar conquistas táticas e conjunturais em meio a uma navegação de longo curso, durante a qual, mesmo sem superar os marcos gerais heterônomos, avanços menores, localizados, para além do significado positivo que possam ter em sí mesmos, podem colaborar político - pedagogicamente, para abrir caminho para conquistas mais ambiciosas no futuro (SOUZA, 2006, p.82).
\end{abstract}

Para Souza (2001) a melhoria da qualidade vida e o aumento da justiça social estão subordinadas à autonomia, ou seja, a autonomia é o parâmetro essencial do desenvolvimento socioespacial, é o parâmetro subordinador, quando se tem autonomia é possível criar ações que venham a melhorar a qualidade de vida e o aumento da justiça social dos vários grupos sociais.

Ser autônomo "significa, assim, "dar-se a sua própria lei", em vez de recebê-la por imposição" (...) "É tomar nas mãos o próprio destino: liberdade política e percepção da história como criação" (SOUZA, 2006, p.69), ao analisar estas frases pode-se entender que a autonomia é fundamental para aqueles que almejam um real desenvolvimento

Souza $(2001 ; 2006)$ aponta a justiça social como sendo derivado da autonomia, o mesmo não pode ser afirmado quando nos referimos à qualidade de vida, pois a liberdade em que se tem num processo decisório não é, por sí só, garantia alguma de que decisões serão acertadas e se traduzirão em melhor qualidade de vida. A justiça social é um parâmetro subordinado que se refere, por exemplo, ao grau de desigualdade socioeconômica e o grau de oportunidade para participação cidadã direta em processos decisórios relevantes, ao nível de segregação residencial, é o parâmetro que está relacionado à esfera pública. 
Já a qualidade vida se refere à esfera privada, à satisfação individual, por exemplo, a melhoria da educação, da saúde, da moradia, a melhoria da qualidade de vida envolve tanto necessidades básicas, quanto não-básica, tanto materiais, quanto imateriais.

O autor ressalta que não se deve buscar uma relação hierárquica entre estes parâmetros, porque entre eles é possível observar uma relação de complementaridade essencial, pois qualquer um deles tomado isoladamente e sem o outro, é insuficiente para servir de base para avaliações e estratégias de desenvolvimento Socioespacial. No entanto vale ressaltar que estes parâmetros, apresentam parâmetros subordinadores particulares tanto na esfera pública, quanta na esfera privada, e que nem sempre as melhorias de um irão acompanhar as melhorias do outro.

Diante do exposto percebe-se que o desenvolvimento socioespacial é o sentido de desenvolvimento que deve ser pensado, pois o desenvolvimento envolve outras dimensões para além da econômica, como pode ser constatado.

\section{Turismo de Base Comunitária e Desenvolvimento Socioespacial: algumas reflexões}

O Turismo de Base Comunitária e o Desenvolvimento Socioespacial apresentam características que fazem com que eles possam ser conceitos a serem trabalhados durante a elaboração de projetos turísticos, pois como mencionado anteriormente o TBC visa proporcionar outra forma de fazer turismo, um turismo que vise melhorias para as comunidades envolvidas e que contribua para preservação do patrimônio cultural das comunidades, pois o turismo de massa tende a impactar e desagregar comunidades que não participam da elaboração e gestão da atividade turística, esta pratica, infelizmente, ainda é muito comum.

Seguindo os princípios apontados no TBC as comunidades devem ser autônomas, devem ter participação ativa nos projetos turísticos, o envolvimento por parte das comunidades deve ocorrer desde o planejamento passando pela execução e gestão de um projeto turístico. É de grande relevância para que eles (comunitários) possam conquistar o tão almejado desenvolvimento no sentido amplo, um desenvolvimento Socioespacial, sendo este possível somente a partir da conquista e ampliação da autonomia, que irá gerar posteriormente qualidade de vida e justiça social. o TBC permite criar os espaços do encontro, no qual os comunitários compartilham o seu cotidiano. Rosário (2010) nos mostra que o TBC

Tem sido referência para a construção de um modelo que viabiliza a inclusão das comunidades do litoral no desenvolvimento do turismo e que contribui para a melhoria dos padrões socioeconômicos, respeitando as tradições e a cultura dos comunitários (ROSÁRIO, 2010, p. 80).

Tendo em vista estas considerações o TBC é compreendido como uma alternativa frente ao turismo de massa, e que associado a ideia de desenvolvimento Socioespacial pode contribuir com o bom andamento de um projeto turístico em áreas de comunidades tradicionais. Um dos objetivos principais é contribuir no desenvolvimento local das comunidades que trabalham com ele, mas é preciso destacar que não se trata somente de desenvolver economicamente, por isso trabalha-se com ideia de desenvolvimento socioespacial apontada por Souza (1997; 2001; 2006). 


\section{Referências bibliográficas}

ADRIÃO, D.; COSTA, M. A. F. Palestra: "O conceito de comunidade e as possibilidades do Turismo de Base Comunitária no pólo Tapajós”. Belém, 06 de janeiro de 2011.

ARAÚJO, G.P.; GELBCKE, D.L. Turismo Comunitário: uma perspectiva ética e educativa de desenvolvimento. Revista Turismo Visão e Ação - Eletrônica, v. 10, no 03. p. 357 - 378, set/dez. 2008. Disponível em: www.univali.br/revistaturismo Acessado em: 24 de junho de 2009.

BARTHOLO, R. Sobre o sentido da proximidade: implicações para um turismo situado de base comunitária. In: BARTHOLO, R.; SANSOLO, D.G.; BURSZTYN, I. (Org.). Turismo de Base Comunitária: diversidade de olhares e experiências brasileiras.1. ed. Rio de Janeiro: Ed. Letra e Imagem, 2009.

BURSZTYN, I.; BARTHOLO, R.; DELAMARO, M. Turismo para quem? Sobre caminhos de desenvolvimento e alternativas para o turismo no Brasil. In: BARTHOLO, R.; SANSOLO, D.G.; BURSZTYN, I. (Org.). Turismo de Base Comunitária: diversidade de olhares e experiências brasileiras.1. ed. Rio de Janeiro: Ed. Letra e Imagem, 2009.

CORIOLANO, L.N.M.T. et al. Arranjos produtivos locais do turismo comunitário: atores e cenários em mudança. Fortaleza: Ed. UECE, 2009.

CRUZ, R.C.A. Turismo, produção do espaço e desenvolvimento desigual. In: BARTHOLO, R.; SANSOLO, D.G.; BURSZTYN, I. (Org.). Turismo de Base Comunitária: diversidade de olhares e experiências brasileiras.1. ed. Rio de Janeiro: Ed. Letra e Imagem, 2009.

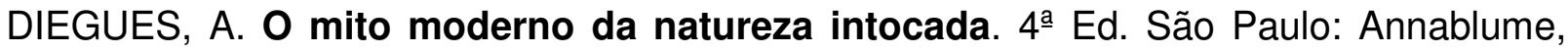
2002.

IRVING, M. Reinventando a reflexão sobre turismo de base comunitária. In: BARTHOLO, R.; SANSOLO, D.G.; BURSZTYN, I. (Org.). Turismo de Base Comunitária: diversidade de olhares e experiências brasileiras.1. ed. Rio de Janeiro: Ed. Letra e Imagem, 2009.

LIMA, R. P.; AYRES, A. R.; BARTHOLO JR., R. S. Turismo de Base Comunitária sob a perspectiva dos Sítios Simbólicos de Pertencimento: O caso da Praia do Sono. In: SEMINÁRIO INTERNACIONAL DE TURISMO, 11, 2009, Curitiba. Anais...Curitiba: OBSTUR/ UFPR: UNIVERSIDADE POSITIVO, 2009. 1 CD-ROM

MATIAS, L.F. Geotecnologias e patrimônio arquitetônico: potencialidades no mapeamento e análise para fins turísticos. In: PAES, M.T.D.; OLIVEIRA, M.R.S. (Orgs.) Geografia, Turismo e Patrimônio Cultura. São Paulo: Annablume, 2010.

MIELKE, E.J.C. Desenvolvimento turístico de base comunitária. Campinas: Ed. Alínea, 2009.

PAES, M.T.D.P. Patrimônio cultural, turismo e identidades territoriais um olhar geográfico. In: BARTHOLO, R.; SANSOLO, D.G.; BURSZTYN, I. (Org.). Turismo de Base Comunitária: diversidade de olhares e experiências brasileiras.1. ed. Rio de Janeiro: Ed. Letra e Imagem, 2009. 
ROSÁRIO, B.A. Políticas de turismo e desenvolvimento socioespacial no município de Soure (llha do Marajó-Pará)- O Turismo de Base Comunitária como alternativa. 2010, TCC (Faculdade de Geografia e Cartografia), IFCH.

SANSOLO, D. Centralismo e participação na proteção da natureza e desenvolvimento do turismo no Brasil. In: BARTHOLO, R.; SANSOLO, D.G.; BURSZTYN, I. (Org.). Turismo de Base Comunitária: diversidade de olhares e experiências brasileiras.1. ed. Rio de Janeiro: Ed. Letra e Imagem, 2009.

SILVA, K.T.P.; RAMIRO, R.C.; TEIXEIRA, B.S. Fomento ao turismo de base comunitária a experiência do Ministério do Turismo. In: (BARTHOLO, R.; SANSOLO, D.G.; BURSZTYN, I. (Org.). Turismo de Base Comunitária: diversidade de olhares e experiências brasileiras.1. ed. Rio de Janeiro: Ed. Letra e Imagem, 2009.

SOUZA, M.L. A teorização sobre o desenvolvimento em uma época de fadiga teórica, ou: sobre a necessidade de uma "teoria aberta" do desenvolvimento Socioespacial. UFRJ: Revista TERRITÓRIO, 1996.

SOUZA, M.L. Mudar a Cidade: Uma introdução crítica ao planejamento e à gestão urbanos. Rio de Janeiro: Bertrand Brasil, 2001.

SOUZA, M.L. A prisão e a Ágora reflexões em torno da democratização do planejamento e da gestão das cidades. Rio de Janeiro: Bertrand Brasil, 2006.

ZECHENER, T.C.; HERIQUEZ, C.; SAMPAIO, C.A.C. Pensando o conceito de turismo comunitário a partir de experiências brasileiras, chilenas e costarriquenha. Anais do II Seminário Internacional de Turismo Sustentável, Fortaleza-CE, maio/2008.

ZAOUAL, H. Do turismo de massa ao turismo situado: quais as transições? In: BARTHOLO, R.; SANSOLO, D.G.; BURSZTYN, I. (Org.). Turismo de Base Comunitária: diversidade de olhares e experiências brasileiras.1. ed. Rio de Janeiro: Ed. Letra e Imagem, 2009.

Alessandra Silva Lobato: Universidade Federal do Pará, Belém, PA, Brasil.

Email: alessandrageo19@yahoo.com.br

Link para o currículo Lattes: http://lattes.cnpq.br/8962068868240430

Data de submissão: 28 de maio de 2012

Data de recebimento de correções: 11 de junho de 2013

Data do aceite: 11 de junho de 2013

Avaliado anonimamente 


\title{
Práticas discursivas e produção de sentidos do "patrimônio": o mito da São Luís (MA), a Atenas brasileira
}

\author{
Discursive practices and production of meanings of "heritage": \\ the myth of São Luís (MA), the Brazilian Athens.
}

\section{Conceição de Maria Belfort Carvalho}

\begin{abstract}
RESUMO
O trabalho problematiza a genealogia do conceito de Patrimônio, avaliando os discursos que constroem uma identidade nacional e, como consequências dão forma a especificidades locais, direcionando a produção de singularidades espaciais. Essa problematização embasa a discussão sobre a constituição da identidade de São Luís em torno da figura da Atenas Brasileira, analisa o conceito de patrimônio dela decorrente e a construção do espaço turístico. Esta pesquisa se orienta pela proposta teórico-metodológica da Análise do Discurso de base foucaultiana (GREGOLIN, 2004; SARGENTINI; NAVARRO-BARBOSA, 2004), cujo pressuposto básico é o de que o discurso está articulado ao sujeito e à História e essa articulação revela a própria trama que dá sentido às palavras e às coisas. Procuramos investigar a produção dos sentidos e seus efeitos (GREGOLIN, 2004) a partir de uma genealogia do discurso do patrimônio, por meio da análise de uma propaganda turística e de um folder.
\end{abstract}

PALAVRAS-CHAVE: Discurso; Patrimônio; Identidades .

\section{ABSTRACT}

This paper is aimed at discussing the genealogy of the concept of heritage, assessing the discourses that build a national identity and as a consequence give way to local specificities, directing the production of spatial singularities. This questioning enhances the discussion on the constitution of São Luis identity around the figure of the Brazilian Athens and the analysis of heritage concept resulting from it. This research is guided by the theoretical-methodological proposal of the discourse analysis based on Foucault principles (GREGOLIN, 2004; SARGENTINI; NAVARRO-BARBOSA, 2004), whose basic assumption, shared by many, and defended by Foucault, is anchored in the idea according to which the discourse is articulated to the subject and history and such articulation reveals the scenario that provides meaning to words and things. We sought to investigate the production of the senses, its effects (GREGOLIN, 2004) from the perspective of heritage discourse genealogy with emphasis on the analysis of tourist propaganda and a folder.

KEYWORDS: Discourse; Heritage; Identity . 


\section{Introdução}

A genealogia para Foucault corresponde a uma concepção teóricometodológica cujo objetivo é perscrutar a história. Caracteriza-se como uma crítica radical à chamada história tradicional cujos procedimentos fundamentam-se em princípios metafísicos e teleológicos que primam pela busca da origem. Na concepção da genealogia não existe uma origem a priori e a posteriori dos acontecimentos, pelo contrário, esses acontecimentos são resultado de forças diversas, muitas delas guiadas pelo acaso. Daí na genealogia se falar em proveniência e emergência dos acontecimentos. Nessa visão, qualquer fato histórico pode ser estudado genealogicamente. É o que faz Foucault ao usar a genealogia no campo das discursividades, tratando do discurso da loucura, da sexualidade, dos prisioneiros etc. A genealogia se opõe ao método histórico tradicional, na medida em que seu objetivo é "assinalar a singularidade dos acontecimentos, fora de toda finalidade monótona" (FOUCAULT, 2007, p. 15). Para ela, inexistem essências fixas, leis subjacentes, finalidades metafísicas.

Ao contrário da história que se fundamenta no contínuo das coisas, no progresso e seriedade, a genealogia busca descontinuidades, recorrências e jogo. Ela transita no espaço da superfície dos acontecimentos, nos mínimos detalhes, nas menores mudanças e nos contornos sutis: observada a correta distância, há uma profunda visibilidade nas coisas. Tudo é interpretação e a genealogia conta a história dessas interpretações, criadas e impostas por outras pessoas e não inerentes à natureza das coisas.

Os discursos que constroem a genealogia de "patrimônio" e a preservação da memória cultural foram gestados em diferentes momentos históricos. Particularmente importante nessa constituição foi o século XVIII, marcado pelo pensamento iluminista, momento em que o homem começa a pensar-se como centro do universo, senhor de sua vontade, um período de intensa valorização da razão. O lluminismo abraçou a ideia do progresso - entendido como a passagem da barbárie à civilização, da animalidade à humanidade - e buscou a ruptura com a história e a tradição. O lluminismo foi um dos momentos mais importantes da modernidade e caracterizou-se pela fragmentação do sujeito e por uma incessante busca pelo progresso. (BERMAN (2007) O conceito de progresso alimentado no século XVIII fez brotar um sentimento de desenvolvimento e de felicidade e a crença de que a civilização humana alcançaria em breve a plenitude. O aperfeiçoamento e o avanço da ciência a serviço da humanidade, aliados às conquistas do homem, o elevariam a um nível civilizacional e o distanciariam da barbárie.

Apesar de consolidar-se no século XVIII, no Renascimento a noção de progresso já se manifestava como consciência de ruptura entre a ordem da cultura e a ordem natural, pois implicava a negação da repetição cíclica.

No século XVIII, tal pensamento associa-se à consciência do caráter progressivo do conceito de civilização. Nesse momento, apesar de existirem vozes dissonantes, como a de Rousseau, que problematizou o conceito de progresso de sua época 
destacando "o bom selvagem" e "mau civilizado", a crença no progresso é um dado que se demonstra com a própria história geral da humanidade, marcada pela convicção num progresso linear e ilimitado, que destacaria a passagem de uma condição de imperfeição à perfeição da espécie humana (FALCON, 1989, p. 62). Mesmo no Século das Luzes havia um discurso que não comungava com a perspectiva de que o progresso traria apenas melhorias para a humanidade. As ações progressistas passaram a conotar também ameaça às tradições, ao que era representativo do passado, do perene.

Nessa concepção de progresso, é possível vislumbrar a temática do patrimônio pelo fato de este abranger questões que se relacionam a temas como o da identidade, pois no dizer de Falcon (1989, p. 62), talvez em decorrência de seu próprio dinamismo intelectual, as "Luzes" se saldam por novas ambiguidades: "frente à tese da perenidade da natureza humana, em todos os tempos e lugares, afirma-se o caráter mutável da espécie humana a partir das próprias evidências empíricas". A tomada de consciência perante a relação paradoxal entre perenidade e mudança levará o homem a eleger símbolos que delimitem os traços de sua identidade, numa busca pela afirmação e legitimação da memória, entendida como a seleção de fatos que merecem ser relembrados. Na escolha de elementos que serão concebidos como patrimônio, é estabelecido um jogo de representações que identificam um grupo social. Os primeiros bens eleitos como patrimônio são associados à elite, como por exemplo, prédios de famílias ricas, igrejas (bens religiosos), fortes (representativos do poder militar) etc.

A concepção de patrimônio, enquanto elemento evocativo da memória local e nacional, perpassa as ações preservacionistas, impondo um debate acerca do sentido e do significado que ele adquire no contexto de uma dada sociedade. Torna-se preponderante compreender que, subjacente às tentativas de retorno ao passado mitológico, empreendidas pelos gestores estaduais e municipais, artistas, arquitetos e intelectuais, coexiste um amálgama de interesses políticos, econômicos e valorativos imbricados na forma como os sujeitos concebem e interpretam o patrimônio e a memória digna de ser preservada.

Para Pesavento (2004, p. 39), representações "são matrizes geradoras de condutas e práticas sociais, dotadas de força integradora e coesiva, bem como explicativa do real. Indivíduos e grupos dão sentido ao mundo por meio das representações que constroem sobre a realidade". Nessa visão, o patrimônio passa a ser visto como um sistema de representação de uma sociedade em uma determinada época. As narrativas de construção de uma identidade nacional, por exemplo, utilizam-se de construtos patrimoniais para enaltecer determinados elementos que são considerados importantes a uma determinada coletividade, na tentativa de impor uma identidade.

Nesse processo, a apropriação está subjacente à seleção de um elemento como patrimônio, pois é entendida como: 
uma resposta necessária à fragmentação e à transitoriedade dos objetos e valores. Apropriar-se é sinônimo de preservação e definição de uma identidade, o que significa dizer, no plano das narrativas nacionais, que uma nação torna-se o que ela é na medida em que se apropria de seu patrimônio (GONÇALVES, 2002, p.24).

A construção de discursos sobre o patrimônio na cidade de São Luís emergiu numa tentativa de afirmação de múltiplas singularidades, e na busca pela preservação de marcos simbólicos imbuídos de um caráter de autenticidade. Por outro lado, a configuração de cidade-patrimônio reveste-se também na imposição de um imaginário social, ou seja, de "um sistema de ideias e imagens de representação coletiva que os homens, em todas as épocas, construíram para si, dando sentido ao mundo" (PESAVENTO, 2004, p.43). Em São Luís, esses elementos são gerenciados de forma a tornar-se alvo da atividade turística.

Diferentes discursos marcam a noção de patrimônio em São Luís. São fatos, memórias, narrativas que entram no processo de edificação do patrimônio imaterial na cidade. Neste trabalho cabe investigar acontecimentos e detalhes que se destacam como elementos de base dessa genealogia: o mito da Atenas Brasileira e que constroem ou reforçam a representação da cidade como Patrimônio da Humanidade._Que discursos produziram essas representações, que sujeitos enunciaram, que instituições se envolveram nesse processo? Como esses discursos constroem e mantêm a imagem de uma São Luís singular e turística? Nesse sentido, é pertinente mobilizar alguns instrumentos de análise que possam explicar a construção dessas identidades patrimoniais.

\section{São Luís, a Atenas Brasileira}

A construção de uma das identidades maranhenses assume seus contornos nos deslocamentos discursivos que edificam o mito de "Atenas Brasileira", que aproxima os costumes ludovicenses (adjetivo pátrio dado aos que nascem em São Luís) de uma cultura erudita e institui uma herança cultural de inestimável importância na constituição da identidade ludovicense. Esse discurso se erige a partir de uma prática discursiva que opera no campo da literatura.

Para compreendermos os processos de constituição dessa identidade, faz-se necessário percorrermos parte do itinerário da história do Maranhão. Nosso percurso tem início com a instalação da Companhia Geral de Comércio do Maranhão e GrãoPará, em 1755, que significou o advento de um processo de ativação econômica sem precedentes no Maranhão. Para o intelectual maranhense Dunshee de Abranches (1822, p. 6), essa medida política praticada pelo Marquês de Pombal teria sido a "aurora da prodigiosa opulência e engrandecimento" da Província. Isso porque as operações da Companhia de Comércio promoveram a entrada do Maranhão no mercado internacional em virtude da exportação do algodão. A Companhia mobilizou o co- 
mércio da província, que passou a receber créditos, ferramentas, escravos. Tais intervenções transformaram o padrão de vida da região, até então mergulhada na miséria, na gentilidade, na barbárie, sem uma economia que a sustentasse (MARTINS, 2006).

Quando as operações da Companhia de Comércio começaram a apresentar traços de retração das relações econômicas, emergiu entre os homens de negócio, principalmente entre os lavradores, um discurso nostálgico de exaltação àquele passado de opulência, que apontava a região como uma terra promissora: "[...] ainda hoje, muitos lavradores abastados bendizem a fortuna e a opulência de seus bens que tiveram sua origem naquela época" (ABRANCHES, 1822, p. 7).

Para o historiador maranhense Mário Meireles (2008), ainda no Império a província presenciou o surgimento de uma elite fundiária e de uma nobreza rural que lhe conferiram uma posição de primeiro plano no cenário nacional, nos campos econômico, político e cultural. O Império é destacado por Meireles como um período da Idade do Ouro do Maranhão.

O açúcar passa a configurar também um produto de exportação e irá somar com a riqueza da terra juntamente com o algodão. Esses dois produtos agrícolas irão constituir a base da economia maranhense e vão gerar mais riquezas e mudanças nos costumes cultivados nesse primeiro momento.

No final do século XVIII e nas primeiras décadas do século XIX a cidade de São Luís passou por novas mudanças em seus costumes. Habituada a frequentar as festas que se resumiam às atividades da Igreja e do Estado, a elite ludovicense mudou seus hábitos culturais, impulsionada, conforme dissemos anteriormente, pelo crescimento econômico decorrente do ciclo do agodão e do ciclo do açúcar, que lhe possibilitou um intercâmbio cultural com a Europa, particularmente com a França. Vários filhos da elite foram para a Europa realizar seus estudos. Esse intercâmbio provocou uma mudança nos costumes dos maranhenses, que influenciados pela Cidade-Luz contribuíram para a transformação de uma minoria da sociedade e introduziram costumes franceses, destacando-se o interesse pelos bons modos, pelo refinamento, pela arte, pelas letras (LACROIX, 2008).

Sob influência do modelo intelectual francês, o teatro tornou-se uma das distrações favoritas, com apresentações de temporadas líricas de companhias de teatro italiana e francesa, realização de concertos de piano, de saraus e serões para moças - que até então nem sabiam ler - aprenderem música, pintura e belas artes (ABRANCHES, 1941).

Esse momento de expressividade cultural reflete os ideais de progresso iluminista na medida em que marca o crescimento intelectual do homem maranhense: os filhos de proprietários assumem a condição de homens das letras. Vale lembrar que o momento era marcado por um espírito romântico, reflexo do estilo literário da época.

No ambiente cultural que se criou na cidade prosperam dois grupos literários com destaque nacional. O primeiro, chamado de Grupo Maranhense (que atuou entre 
1832 e 1868) - a Primeira Geração - influenciado por uma mentalidade senhorial e um sentimento aristocrático, inaugurou uma prática discursiva de exaltação das riquezas e belezas da terra natal, e se fundamentará com a Segunda Geração na crença e superioridade do homem maranhense (LACROIX, 2008).

A efervescência cultural na qual mergulhou a cidade de São Luís após a constituição do Grupo Maranhense fez emergir o epíteto de Atenas Brasileira'1. Os intelectuais e homens das letras que surgem em torno da "cidade letrada" ${ }^{2}$ de colonização portuguesa, como a cidade de São Luís - um dos poucos centros de intensa atividade intelectual do primeiro e segundo período imperial brasileiro - são chamados de "atenienses". Segundo Martins (2008, p. 294, grifo do autor), "um modo muito produtivo de compreender o mito da 'Atenas Brasileira' é analisar a construção alegórica ou simbólica do passado de São Luís do Maranhão como cidade letrada. O que está em jogo é a origem de um mito", que se fundamenta no resgate do passado de glórias. O autor acrescenta que "a genealogia da construção simbólica de São Luís como 'Atenas Brasileira' é um mito legitimador do Maranhão oitocentista e de um projeto de literatura nacional, até de nacionalidade". Nesse sentido, a identidade maranhense vai se perfazendo a partir de uma construção que se dá no campo das letras.

Do Grupo Maranhense ressalta-se Manuel Odorico Mendes, Francisco Sotero dos Reis, João Francisco Lisboa, Trajano Galvão de Carvalho, Antonio Gonçalves Dias, Antonio Henriques Leal, Joaquim Gomes de Sousa, aos quais podem ser acrescentados os nomes de Joaquim de Sousa Andrade, o Sousândrade e César Augusto Marques. Outros intelectuais de menor repercussão também são destacados: Lisboa Serra, Almeida Braga, Marques Rodrigues, Vieira da Silva, além de Cândido Mendes de Almeida, Pedro Nunes Leal, Belarmino de Matos, Gentil Homem d'Almeida Braga, Antônio Joaquim Franco de Sá, Francisco Dias Carneiro, Joaquim Serra (VERÍSSIMO, 2003).

Gonçalves Dias é fiel ao sentimento nacionalista em que se ancora o Romantismo. Autor do poema I-Juca Pirama, que destaca o índio como figura representativa da nação brasileira, o poeta se eternizou na Canção do Exílio, reconhecida como um dos poemas de temática mais nacionalista de todos os tempos.

A proclamação da República, a abolição da escravatura, a queda da agroexportação e todas as consequências que resultaram desse processo produzem uma mudança no panorama maranhense e a historiografia registra um ciclo decadentista cultural entre 1894 e 1932.

Intelectuais maranhenses como Miguel Vieira Ferreira e Fábio Alexandrino de Carvalho Reis apontam a sensação de decadência da elite da época (MARTINS, 2006). Ferreira (1866, p. 107-108) destaca um estado de letargia vivida por todos:

O nosso espírito é pouco profundo, o nosso typo é o da indolência e fraqueza mental, e por isso mesmo o da superficialidade; [...] entre nós escreve-se muito, muito se projeta, mas não se escrevem obras, nem se fazem trabalhos desenvolvidos [...]. 
Reis (1877, p. 21-22) conclama a elite regional para um trabalho de mudança do estado em que todos se encontravam:

\begin{abstract}
Accordemos do lethargo emquanto é tempo, pois já nos achamos a dous passos do abysmo; e é preciso transpolo-o ou cair n'elle, o que dirão de nós os nossos vindouros, quando souberem que recebemos dos nossos antepasados este bello torrão prospero e fluorescente e Ih'o legamos empobrecido e decadente, por falta de iniciativa, de actividade e energia?
\end{abstract}

Para uma elite que até então se alimentava de uma tradição de grande efervescência econômica e cultural, era o momento de propor mudanças no sentido de resgatar a glória do passado.

A Segunda Geração, que atuou entre 1870 e 1890, tentou manter a tradição de Atenas Brasileira, por meio de um "rejuvenescimento literário". Ancorada nos princípios republicanos que pregavam, dentre outras coisas, a modernidade, a Segunda Geração testemunha uma negação da herança colonial portuguesa. Os "novos atenienses", como eram chamados os intelectuais da Segunda Geração, consolidaram uma formação discursiva que se perfaz na "ideologia da singularidade", a partir da valorização da fundação francesa da cidade de São Luís. Esse discurso de fundação francesa implica num retorno às origens, ou seja, à fundação da capital, mas ao mesmo tempo significa um salto para o futuro, pois a França simbolizava os novos tempos. Esse discurso torna o homem maranhense singular diante do cenário nacional, já que a capital maranhense é a única reconhecida, oficialmente, como capital brasileira de fundação francesa.

O discurso da singularidade emerge numa época de momentâneo crescimento econômico, que estimulou o luxo, a sofisticação, produziu uma mudança no comportamento da elite maranhense e fez emergir uma mentalidade de superioridade do homem, numa tentativa de manter distante o passado lusitano. $O$ discurso de valorização do homem maranhense é marcado pelo declínio econômico. A consciência de que esse homem gozava da virtude da sabedoria, da excelência e quase exclusividade no panorama cultural brasileiro foi impregnada no imaginário da sociedade local, chegando a alcançar repercussão nacional. Projetado segundo as lentes de um "questionável esplendor, o maranhense sentiu-se superior às populações das outras províncias e procurou buscar uma diferença, ainda que mítica, em suas origens" (LACROIX, 2008, p. 66).

A economia de base agroexportadora, que até então era o alicerce do mercado local, foi inviabilizada por medidas como as inúmeras leis abolicionistas que culminaram na assinatura da Lei Áurea, em 1888. A Atenas Brasileira irá respirar os novos ares trazidos pela industrialização que tomou conta do país, e receberá um novo epíteto: Manchester do Norte, uma alusão à cidade inglesa de Manchester, um dos ber- 
ços da Revolução Industrial. Essa descontinuidade discursiva que move os enunciados São Luís, Atenas Brasileira; São Luís, Manchester do Norte - ancora-os em certas condições de existência. No primeiro momento, o da Atenas Brasileira, há uma valorização da tradição colonial, enquanto no segundo, o da Manchester do Norte, vai haver uma negação dessa tradição, mobilizada pelos ideais de modernidade que ganhavam espaço na capital maranhense.

Essas configurações revelam um conceito de patrimônio cultural que se edifica no campo imaterial, na medida em que diz respeito à cultura e às tradições de um grupo social. A construção da ideia de Atenas Brasileira ocorre num momento de efervescência cultural, de grande produção literária com forte tendência colonial. A construção da Manchester do Norte ancora-se em uma ideia de modernidade, mas vai buscar no passado traços da presença dos franceses, fazendo emergir uma ideologia da singularidade. Essa singularidade, até hoje associada à fundação da capital maranhense, estaria associada também ao discurso da modernidade inaugurado na França.

Portanto, antes mesmo de se cunhar o conceito de "patrimônio" em São Luís, temos nos discursos desse momento a ideia de patrimônio associada ao campo imaterial. Nesse sentido, o conceito de patrimônio decorrente do discurso da Atenas Brasileira configura-se em torno da identidade marcada pelos intelectuais letrados.

Essa ideia tem sido revisitada no discurso oficial como uma estratégia para o desenvolvimento do turismo na capital maranhense. O patrimônio imaterial compreende os bens de caráter processual e dinâmico, ou seja, modos de fazer, costumes e saberes. A construção da Atenas Brasileira compreende os saberes de uma época e traça identidades em São Luís que se reflete na crença dos sujeitos de que a capital é aquela "onde se fala o melhor português", por exemplo, e a população local incorpora essa identidade como mais um elemento atrativo para o turismo local.

Não devemos pensar, entretanto, que a identidade seja construída e destruída linearmente. Ao contrário, as transformações históricas e as mudanças nas representações coletivas não se dão de um momento para outro nem se apagam por passes de mágica. Pela própria natureza complexa das tramas discursivas que as fazem emergir elas permanecem mesmo depois de superadas suas possibilidades históricas. Elas permanecem à espreita, sabedoras da possibilidade de sempre retornarem e dialogarem com novos discursos. Por isso, a concepção de patrimônio imaterial, desenhada pelo discurso da Atenas Brasileira e pelo resgate do passado europeu é muito forte até hoje, como se observa em uma propaganda turística oficial veiculada em 2003 (Figura 1).

Nesta propaganda, chama-nos atenção o enunciado:

"SUBI a ladeira do Desterro como os holandeses, franceses e portugueses que nos amaram na aventura. O cheiro da Terra e o sacrifício de chegar em caravelas nos indicam os caminhos de voltar. Ninguém partiu mas todos voltaram".

(José Sarney - Romancista) 


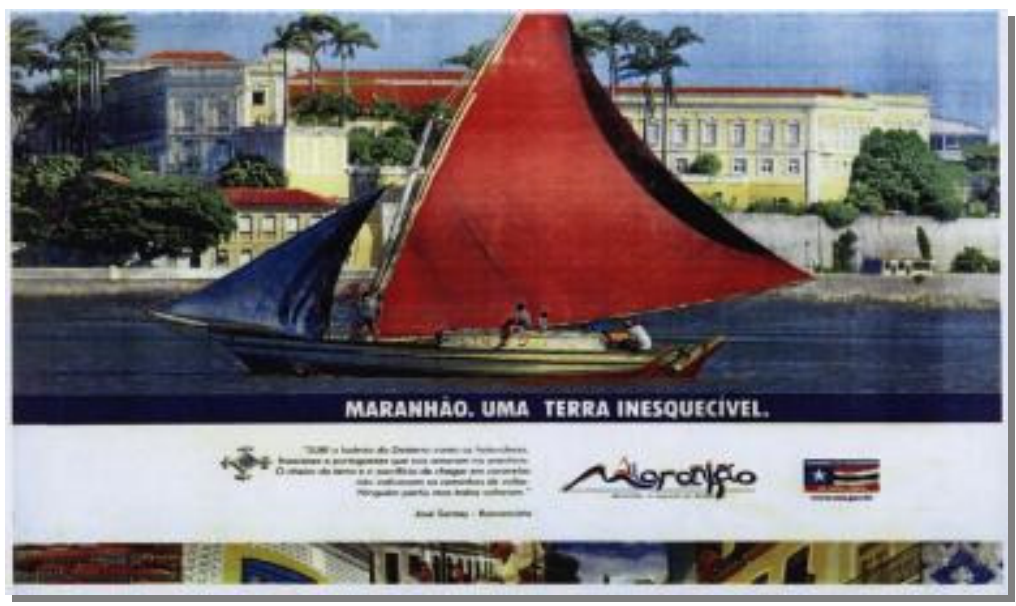

Figura 1: Propaganda turística, Governo do Maranhão, 2003. Fonte: Portal do Governo do Estado. Figure 1: Marketing touristic, Government of Maranhão, 2003. Source: Portal of the State Government.

Para construir o sentido do Maranhão como "terra inesquecível", a propaganda recorre à memória discursiva do passado glorioso, retomando a construção histórica de nossas origens europeias. Ao enumerar "os holandeses, franceses e portugueses que nos amaram na aventura", o texto rememora e reatualiza o mito da Atenas na mesma medida em que apaga outros atores históricos (os indígenas, os africanos escravizados). Ao emergir, em pleno século XXI, esse enunciado reitera, na descontinuidade histórica, uma das identidades maranhenses que as tramas discursivas colaram na memória coletiva.

Segundo Davallon (1999), a memória coletiva só retém do passado o que ainda é vivo ou capaz de viver na consciência do grupo que o mantém. Ela não ultrapassa o limite do grupo. Em São Luís, o grupo de intelectuais (escritores, jornalistas) contribuiu para perpetuar o mito da Atenas Brasileira.

A memória da Atenas Brasileira conserva sua força e atravessa a barreira do tempo deixando sua impressão na memória da comunidade social. Essa memória movimenta a cidade turisticamente, na medida em que há uma ressignificação do espaço. Segundo Coriolano (2009), o turismo se reproduz transformando os espaços em mercadoria, seguindo uma lógica do capital. Essa atividade é uma das principais responsáveis pela produção dos espaços na sociedade contemporânea, agindo no sentido de desterritorializar e produzir novas configurações geográficas. O espaço passa a ser precioso, valorizado.

$\mathrm{Na}$ Figura 2, percebemos o agenciamento de várias identidades. Esse folder reforça a discursividade que constrói a cidade de São Luís como palco da diversidade. O texto verbal destaca e convoca a memória das várias identidades da capital, dentre elas a de Atenas Brasileira e a de Patrimônio Cultural da Humanidade. A enunciação aponta que como cidade Patrimônio Cultural da Humanidade São Luís tornouse um lugar heterotópico, um espaço em que a simultaneidade das identidades acon- 
tece. "É o tudo, ao mesmo tempo, agora", apresentado como o singular da capital maranhense.

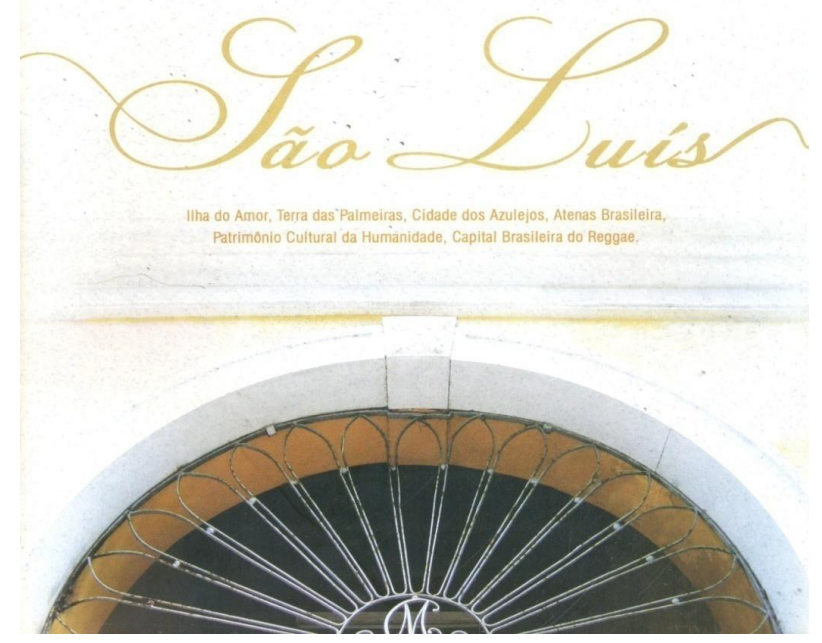

Figura 2: Folder turístico. São Luís, junho 2009. Prefeitura de São Luís. Fonte: São Luís (2009).

Figure 2 - Folder tour. São Luis, June 2009. Prefecture of São Luis. Source: São Luiz (2009).

Dentro da pós-modernidade, devido a uma situação caótica de fragmentação das identidades, da perda de referências gerada por inúmeras transformações nas concepções de tempo e espaço, derivadas, sobretudo, da invenção de novas tecnologias, que aproximaram mundos dantes incomunicáveis, o passado adquiriu muito valor, pois nele estariam as referências de que um povo precisaria para não perder seu "norte". Dessa forma, na cidade de São Luís, as campanhas de patrimonialização direcionaram suas políticas em publicidades que destacam o passado como símbolo de uma memória capaz de sustentar a identidade do povo. Assim, enunciados gerenciados pelo Governo do Estado (governo de Jackson Lago) põem em funcionamento a importância que o passado tem para a elaboração das referências da cidade, ao mesmo tempo em que constroem uma ideia de espaço e promovem sua imagem, destacando as relações de poder que estão imbricadas nesse processo.

Compreender a produção do espaço nesse mercado implica em entendê-lo como uma construção. Ele é, simultaneamente, o lugar das estratégias para o capital e das resistências do cotidiano para os habitantes. A atividade turística é uma das mais recentes modalidades do processo de acumulação, que produz novas configurações geográficas e materializa o espaço de diferentes perspectivas, pela ação do Estado, das empresas, dos residentes e dos turistas.

\section{Considerações finais}

Nossa pesquisa buscou mostrar que, em São Luís, a genealogia do conceito de patrimônio mobiliza várias práticas discursivas. A afirmação de múltiplas singularidades se edifica por meio de um imaginário social, a partir de "um sistema de ideias e imagens" construído pela elite dominante. Nesse processo histórico, vários acontecimentos fazem irromper o conceito de patrimônio. 
Focalizamos o elemento de base dessa genealogia, que é o discurso que se constrói em torno do mito da Atenas Brasileira, que reflete uma visão imaterial de patrimônio, e que se edifica no campo literário, na voz de intelectuais maranhenses. A edificação desse mito se dá a partir de uma tentativa de aproximar os costumes ludovicenses ao de uma cultura erudita. No ambiente cultural que se formou na cidade, destacaram-se dois grupos literários. O primeiro - o Grupo Maranhense - se destacou no cenário nacional e inaugurou uma prática discursiva de exaltação das riquezas e belezas da terra natal, e produziu no segundo grupo - a Segunda Geração - a crença na superioridade do homem maranhense.

Essa identidade e o conceito de patrimônio dela decorrente convivem com outras identidades (Manchester do Norte, Cidade Patrimônio da Humanidade, Capital brasileira do Reggae, dentre outras) e conceitos forjados ao longo da história, dialogando seja pela polêmica, seja pela contratualidade, produzindo relações sociais e espaciais que se transformam no fluxo do tempo. Mas isso não se faz sem conflitos, contradições e resistências. Cada local, região ou país tem sua formação própria, sua cultura, valores e costumes e desse modo o espaço do turismo é produzido conforme essas relações mais amplas, em um processo articulado à produção geral da sociedade.

\section{Referências bibliográficas}

ABRANCHES, D. O Captiveiro. Rio de Janeiro: Jornal do Comércio, Rodrigues \& C, 1941.

ABRANCHES, D. Espelho crítico-político da província do Maranhão. Lisboa: Typ. Rollandianna, 1822.

BERMAN, M. Tudo que é sólido desmancha no ar: a aventura da modernidade. 2. ed. São Paulo: Companhia das Letras, 2007.

CORIOLANO, L.N.M.T. Espaço, poder e turismo: novas configurações geográficas. Disponível em: <http://www.sbpcnet.org.br/livro/57ra/programas/CONF SIMP/textos/ luzianeidecoriolano-reestruturacao.htm>. Acesso em: 18 out. 2009.

FALCON, F.J.C. Iluminismo. 2. ed. São Paulo: Ática, 1989.

FERREIRA, M.V. Reflexões acerca do progresso material da província do Maranhão. Maranhão: Typ. do Frias, 1866.

FOUCAULT, M. O nascimento da medicina social. In: FOUCAULT, M. Microfísica do poder. Organização e tradução de Roberto Machado. 23. ed. Rio de Janeiro: Graal, 2007.

GREGOLIN, M.R. Foucault e Pêcheux na Análise do Discurso. São Carlos: Editora Claraluz, 2004.

GONÇALVES, J.R.S. A retórica da perda: os discursos do patrimônio cultural no Brasil. 2. ed. Rio de Janeiro: UFRJ/ IPHAN, 2002.

LACROIX, M.L. A fundação francesa de São Luís e seus mitos. 3. ed. São Luís: EDUFMA, 2008. 
MARTINS, R.S. Atenienses e fluminenses: a invenção do Cânone Nacional. Anais do Seta, Campinas, v. 2, p. 293-298, 2008. Disponível em: <http://www.iel.unicamp.br/revista/ index.php/seta/article/viewFile/435/361>. Acesso em: 5 mai. 2012.

MARTINS, M.B. Operários da saudade: os novos Atenienses e a invenção do Maranhão. São Luís: EDUFMA, 2006.

MEIRELES, M.M. História do Maranhão. 4. ed. Imperatriz: Ética, 2008.

PESAVENTO, S.J. História e História Cultural. Belo Horizonte: Autêntica, 2004.

RAMA, A. A cidade das letras. São Paulo: Brasiliense, 1985.

REIS, F.A.C. Cartas a um velho amigo: ligeiro estudo sobre o estado econômico e industrial do Maranhão. Rio de Janeiro: Tipografia de Domingos Luiz dos Santos, 1877.

SARGENTINI, V.; NAVARRO-BARBOSA, P. (Orgs.). Foucault e os domínios da linguagem: discurso, poder, subjetividade. São Carlos: ClaraLuz, 2004.

Notas:

${ }^{1}$ Outras cidades brasileiras como Fortaleza, Olinda, Recife, Salvador, Rio de Janeiro receberam, também, ao longo do século XIX, o cognome de "Atenas Brasileira". Esse cognome era atribuído sempre que um grupo de intelectuais e literatos desenvolvia um volume de atividades culturais e literárias, tais como publicações, polêmicas e eventos que engrossavam as fileiras do nascente mundo literário e cultural dos oitocentos brasileiros (MARTINS, 2008).

${ }^{2}$ A ideia que constrói o conceito de cidade letrada se fundamenta na participação de intelectuais e letrados na construção e consolidação da sociedade latino-americana desde a conquista ibérica até o início do século XX, com o propósito de relacioná-los ao campo do poder (RAMA, 1985).

Conceição de Maria Belfort Carvalho: Universidade Federal do Maranhão, São Luis, MA, Brasil.

Email: cbelfort@globo.com

Link para o currículo Lattes: http://lattes.cnpq.br/7821541616565704

Data de submissão: 24 de maio de 2012

Data de recebimento de correções: 09 de janeiro de 2013

Data do aceite: 11 de junho de 2013

Avaliado anonimamente 
Gomes, M.M. Oliveira, C.D.M. As festas de Nossa Senhora da Conceição e a encenação da Paixão de Cristo: os desafios ao lugar do patrimônio imaterial e turístico em Pacatuba (CE). Revista Brasileira de Ecoturismo, São Paulo, v.6, n.3, ago/out-2013, pp.674-691.

\title{
As festas de Nossa Senhora da Conceição e a encenação da Paixão de Cristo: os desafios ao lugar do patrimônio imaterial e turístico em Pacatuba (CE) ${ }^{1}$
}

\begin{abstract}
The Parties of Nossa Senhora da Conceição and the play off Christ Passion: the challenges to immaterial heritage and tourism in Pacatuba city (CE, Brazil)
\end{abstract}

\section{Maryvone Moura Gomes, Christian Dennys Monteiro De Oliveira}

\section{RESUMO}

O presente trabalho objetiva discutir o lugar a partir das dinâmicas geográficas vivenciadas entre as festas de Nossa Senhora da Conceição e da Encenação da Paixão de Cristo em Pacatuba - Ceará, analisando a representação simbólica que as festas dão ao lugar, buscamos compreender de que maneira a festa espetacular desafia $\mathrm{Pa}-$ catuba enquanto bem patrimonial e turístico. Nossas análises baseiam-se em Mafesolli, Ferrara, Eliade, Di Méo, Duvignaud e Canclini, e em outros autores que trabaIham essa temática. Deste modo, a partir da abordagem cultural em geografia, bem como o relevante auxílio de outras ciências humanas a exemplo da Antropologia e Sociologia, que nos permitiram uma leitura requerida para o entendimento da espacialidade festiva. Para tanto, foi realizada pesquisa documental, observações em campo, entrevistas com organizadores e representantes da prefeitura. São os desafios da reflexão sobre a alter identidade das duas festas diante da espetacularização midiática posta, que graças a ela ou apesar dela, cabe à pesquisa evidenciar.

PALAVRAS-CHAVE: Festas; Lugar; Patrimônio; Turismo; Pacatuba (CE).

\section{ABSTRACT}

The present paper discusses the place starting from the analysis of geographical dynamics experienced by the comparison between the parties of Nossa Senhora da Conceição and the play of Passion of Christ in the city of Pacatuba - Ceará, analyzing symbolic representation that the parties give the place, we seek to understand how the spectacular party challenges Pacatuba's heritage and tourism. Our analysis is based on contributions of Mafesolli, Ferrara, Eliade, Di Meo, Duvignaud, Canclini and other authors. In this research we considered the cultural approach in geography and the assistance of other relevant social sciences like anthropology and sociology, allowed us to achieve the necessary skill for understanding the spatiality of these events. Were also performed documentary research, field observations, interviews with organizers and local authorities. The challenge on this research is the reflection on the alter identity of the two parties against the place and the "thanks to or in spite of the media spectacle" evidence being a very important view to consider.

KEYWORDS: Traditional Parties; Place; Heritage; Tourism; Pacatuba (CE, Brazil). 
As festas de Nossa Senhora da Conceição e a encenação da Paixão de Cristo: os desafios ao lugar do patrimônio imaterial e turístico em Pacatuba (CE)

\section{Introdução}

Hoje é dia de festa! A cidade se arruma, as moças se enfeitam, os rapazes se animam e a criançada se diverte. As cidades se vestem de cores, luzes e brilhos, em um palco que transforma o cotidiano em um dia especial, dia de festejar. É assim que as cidades sejam do interior ou da capital se preparam para a festa. Porém, "novas formas de viver o festejo ou a redescoberta de formas antigas para nosso mundo parecem estender o poder e o significado da festa" (grifos do autor) (BRANDÃO, 2010, p.21). E são por essas formas antigas ou novas que iremos descortinar o poder das festas de Nossa Senhora da Conceição e a Encenação da Paixão de Cristo em Pacatuba/Ce na construção do lugar enquanto espaço vivido e simbolizado.

A pesquisa intitulada As Festas de Nossa Senhora da Conceição e a Encenação da Paixão de Cristo: os desafios ao lugar do patrimônio imaterial e Turístico em Pacatuba$C E$, concentra-se em estudar o lugar em sua densidade simbólica e como a festa espetacular desafia Pacatuba enquanto bem patrimonial e turístico.

A composição da festa, o lugar simbólico, o modo como ela se espacializa, os ritos, as celebrações, as danças, as músicas, as representações, os sujeitos que participam direta e indiretamente, são elementos que estabelecem funções na sua organização e sua produção.

Desde a Idade Média, as festas se fazem presentes no cotidiano das pessoas como forma de representação da cultura popular. Era na festa de carnaval, como descreve Bakhtin em seu livro "A Cultura Popular na Idade Média e no Renascimento", sobre a obra de François Rabelais, que se tinha a abdicação provisória de todas as relações hierárquicas, de todos os privilégios, regras e tabus. Contudo, atualmente, podemos observar que as festas continuam, apesar das mudanças, sendo marcas das metrópoles brasileiras.

O ato de festejar é uma forma de extravasar, celebrar, dançar e por que não dizer de representar. A festa ocorre em um lugar único, um conjunto "especial" que tem história e significados. (TUAN, 1979, p. 387) O momento festivo é um espaço-tempo vivido e, portanto simbólico, cheio de significados e representações para quem participa da celebração.

Para Durkheim, a festa é um estado de "efervescência" que propicia a aproximação dos indivíduos, tem sua marca no júbilo e no prazer, sendo, portanto, uma dimensão transgressiva (DURKHEIM, 1912, p. 542-548 apud MAIA, 1999, p. 192-193). Já Amaral destaca que:

As festas parecem oscilar (...) entre dois pólos: a cerimônia (como forma exterior e regular de culto) e a festividade (como demonstração de alegria e regozijo). Elas podem se distinguir dos cotidianos por sua amplitude e do mero divertimento pela densidade. Na verdade, os dois elementos têm afinidades (1998, p. 38).

Contudo, é nesse estado de efervescência, delírio e oscilações, que as festas ganham importante destaque na dinâmica das cidades brasileiras, pela pluralidade de sentimentos por elas criada, como sentimentos de pertencimento, de fé e devoção, de recria- 
ção e ritualização, que fazem com que as especificidades locais sejam vistas e sentidas de forma mais explícita.

No Estado do Ceará algumas festas do ciclo natalino e junino vêm ganhando destaque no imaginário popular, na cultura e mídia, são exemplos às festas de padroeiro, folias de reis, pastoril, lapinhas, festivais juninos, entre outras. A pesquisa corresponde a investigação a respeito das festas populares do ciclo natalino e junino nos municípios de Pacatuba e Maracanaú - Região Metropolitana de Fortaleza - Ceará, Brasil, que vem ganhando forma pela apropriação dos espaços festivos, pela resistência e conservação da tradição adquirindo a condição de "espetáculos urbanos" para manter a vitalidade da tradição em um contexto pós-moderno. O presente artigo é produto do projeto de pesquisa financiado pela CAPES e Ministério da Cultura, pelo edital Pro-cultura/2009 denominado A Dimensão territorial das festas populares e do turismo: estudo comparativo do patrimônio imaterial em Goiás, Ceará e Sergipe, desenvolvido pela rede: Programa de Pós-Graduação em Geografia da UFC, Laboratório de Estudos e Pesquisas das Dinâmicas Territoriais - LABOTER e Programa de PósGraduação em Geografia do Instituto de Estudos Socioambientais da UFG e Núcleo de Pós-Graduação em Geografia da UFS.

A grande diversidade cultural do Estado do Ceará possibilita que os organizadores desses eventos utilizem como artifício para manutenção das tradições, a espetacularização, o formato de festival, a cenografia, a criação de espaços temáticos, entre outras formas também presentes nos grandes eventos festivos.

Contudo, as festas criam teias de significados tecidas pelo homem ligadas as experiências, valores, representações, mitos e ritos que expressam a identidade de um grupo, vividos no lugar. A proposta desse estudo é analisar o lugar simbólico da cidade de Pacatuba, como referência topológica dos dois ciclos festivos: "natalino" e "junino", tendo como objeto empírico de investigação a festa de Nossa Senhora da Conceição (padroeira da cidade), comemorada em 8 de dezembro, no ciclo natalino; e a Encenação da Paixão de Cristo, realizada na semana santa, antecipando o ciclo junino na abertura do ciclo pascal. Neste sentido, essa segunda festa anuncia os eventos do ciclo mais festivo, o junino, podendo por isso catalisar a força midiática que o evento tomou.

A pesquisa apresenta uma abordagem qualitativa, baseada na realização de entrevistas semiestruturadas, enquetes e relatos dos moradores, visitantes, pároco da igreja matriz e organizadores das referidas festas sobre suas experiências. Os levantamentos de campo foram feitos em dois momentos: nos meses de abril/junho e novembro/dezembro de 2011. Além de pesquisa documental em matérias de jornais digitais (O Povo e Diário do Nordeste) e sites institucionais, tomando como base as publicações nos anos de 2000 a 2010.

Esses dados serviram para a compreensão da dinâmica espacial das festas que ocorrem nos natalino e junino, considerando-se a espacialidade dos processos e sua complexidade na pós-modernidade. 
As festas de Nossa Senhora da Conceição e a encenação da Paixão de Cristo: os desafios ao lugar do patrimônio imaterial e turístico em Pacatuba (CE)

\section{As festas cíclicas na Região Metropolitana de Fortaleza}

As festas religiosas seguem o calendário litúrgico da Igreja Católica Apostólica Romana (ICAR), orientando as celebrações e ritos praticados pelos cristãos durante todo ano. O calendário é divido em Ciclo Pascal ${ }^{2}$, Ciclo Natalino ${ }^{3}$ e Tempo Comum ${ }^{4}$. As duas principais celebrações cristãs são o Natal e a páscoa, pois no Natal se celebra o nascimento de Jesus Cristo e na Páscoa sua morte e ressurreição.

Essas festas possuem grande significado para os cristãos, pois é através dos ritos festivos que o homem religioso se aproxima dos deuses. Como ressalta Eliade (2001), o mundo renova-se anualmente, isto é, reencontra a cada ano a santidade original, tal como quando saiu das mãos do Criador. As festas religiosas são de grande significado para os cristãos, pois é na festa através dos ritos que o homem religioso se aproxima dos deuses.

Como atividade para compreendermos as festas religiosas e de calendário, consideramos analisar as dinâmicas das festas cíclicas (juninas e natalinas) no Estado do Ceará proposto pelo Projeto Pró-Cultura. Concomitantemente aos levantamentos de campo, também construímos o banco de dados das festas populares do Estado do Ceará, produto do Projeto Pró-Cultura, a partir de pesquisa documental em matérias de jornais digitais, conforme já foi mencionado. O banco de dados vem servindo de apoio à composição de tabelas e para as análises das festas cadastradas nesse estudo. O Quadro 1 sintetiza as características gerais das festas nos ciclos natalino e junino.

Quadro 1: Características das festas do ciclo natalino e junino.

Table 1: Characteristics of feasts of the cycle Christmas and "junino".

\begin{tabular}{|c|c|}
\hline \multicolumn{2}{|c|}{ Características Gerais das Festas Cíclicas na RMF/Ceará } \\
\hline CICLO NATALINO & CICLO JUNINO \\
\hline Festas que remetem aos santos do ciclo; & Festas que remetem aos santos do ciclo; \\
\hline $\begin{array}{c}\text { Período de comemoração ao nascimento } \\
\text { de Jesus Cristo, momento de mudanças e } \\
\text { renovação; }\end{array}$ & Festa da colheita; \\
\hline $\begin{array}{c}\text { Presença mítica forte; } \\
\text { Apresentação de danças folclóricas; }\end{array}$ & Danças, trajes típicos, e culinária própria do \\
período;
\end{tabular}

Fonte: Jornais O Povo e Diário do Nordeste. Organizado por Maryvone M. Gomes, Nov/ 2011. Source: Journals "O Povo" and "Diário do Nordeste". Organized by Maryvone M.Gomes, Nov/2011. 
Analisando o quadro acima, notadamente se destacam as festas em homenagem aos santos em ambos os ciclos. As danças, trajes e comidas típicas marcam os dois ciclos, assim como os rituais festivos e os símbolos. É no momento da festa que a identidade cultural de um grupo torna-se mais visível, na medida em que o ambiente simbólico da festa estrutura a paisagem enquanto um sistema de significados (COSTA, 2010).

O Calendário litúrgico da ICAR cobre todo o ano litúrgico, com passagens, acontecimentos bíblicos e em especial duas grandes celebrações: o natal e a páscoa, são os momentos vivenciados mais intensamente pelo cristão. As festas do ciclo natalino fazem referência a uma das principais celebrações cristãs, o nascimento de Jesus Cristo. As festividades desse ciclo iniciam em 24 de dezembro e finaliza-se no dia 07 de janeiro com festa do Batismo do Senhor, pelo calendário cristão. O Natal é uma data simbólica, uma convenção da cristandade, que representa o nascimento de Jesus Cristo para os cristãos. Diz a tradição, que o dia 25 de dezembro foi adotado para que a data coincidisse com a festividade romana dedicada ao "nascimento do deus sol, que comemorava o solstício de inverno", em cultos pagãos. A data era tida também como o do nascimento do deus persa Mitra, o Sol da Virtude.

Alguns estudiosos dizem que a Igreja, no século IV, tornou muitas datas de festas pagãs em festas cristãs como forma de conversão cada vez maior de povos pagãos ao cristianismo. Os festejos desse ciclo remetem as festas de padroeiros, Epifania, Festa do Divino Espírito Santo, Folias de Reis e Pastoril. Em algumas regiões do Estado o ciclo se estende até fevereiro com a festa de Nossa Senhora das Candeias. Com o caminhar dos levantamentos das festas cíclicas, constatamos que estas não se situam estaticamente em um determinado ciclo, mas transbordam para outros ciclos ou transitam entre os ciclos festivos obedecendo à necessidade dos que a produzem. Elas permitem a maleabilidade das localidades em trabalhar a espetacularização dos eventos, conforme seu poder de oferta para atender as demandas crescentes.

Algumas festas desse ciclo vêm ganhando destaque no imaginário popular, na cultura e mídia. No Estado do Ceará, as festas nesse período celebram os autos de Natal, lapinhas e os presépios, são acompanhados de danças como pastoril e reisados. Segue abaixo quadro das atividades de campo das festas do ciclo natalino realizada pela equipe Pró-Cultura Ceará referente à 2010/2011. Nos levantamentos de campo realizados no ciclo natalino, destacamos a forte presença mítica presentes nas festas de padroeiros, reisados e lapinhas (Quadro 2).

Podemos notar em alguns locais pesquisados a presença de muitos fieis nas festas religiosas natalinas, porém nem os novos atrativos incorporados às festas, nem os apelos espetaculares com estruturas exuberantes, conseguiram atrair o turista para alguns das festas realizadas nesse período. O que sinaliza que a construção de espetáculos para festividades tradicionais nas cidades metropolitanas não rompe com o processo de invisibilidade do evento, dificultando assim uma gestão integrada com o turismo. Concluímos que o turista não é atraído apenas pela festa, mas também pelo conjunto de atrativos oferecidos pela localidade. 
As festas de Nossa Senhora da Conceição e a encenação da Paixão de Cristo: os desafios ao lugar do patrimônio imaterial e turístico em Pacatuba (CE)

Quadro 2: calendário de atividades de campo - ciclo natalino.

Table 2: schedule of field activities - Christmas Cycle.

\begin{tabular}{|r|c|c|}
\hline \multicolumn{2}{|c|}{ Pesquisa de campo - Ciclo Natalino - Equipe Ceará Pró-Cultura } \\
\hline FESTA & LOCAL & DATA \\
\hline Nossa Senhora da Conceição & Pacatuba - CE & $03 / 12 / 10$ à 08/12/10 \\
\hline Nossa Senhora da Conceição & Messejana - Fortaleza/CE & $08 / 12 / 10$ \\
\hline Festa de Santa Luzia & Meireles - Fortaleza/CE & $13 / 12 / 10$ \\
\hline Pastoril & Dragão do Mar - Fortaleza/CE & $18 / 12 / 10$ \\
\hline Natal de Brilho & Maracanaú - CE & $21 / 12 / 10$ \\
\hline Folias de Reis, lapinhas e reisados & Juazeiro e Crato/CE & $04 / 01 / 11$ à 08/01/11 \\
\hline Festa de São Sebastião & Goiabeiras - Fortaleza/CE & $20 / 01 / 11$ \\
\hline
\end{tabular}

Fonte: Projeto Pró-cultura Ceará. Organizado por Maryvone M. Gomes, Jan/2011.

Source: Pró-cultura Ceará Project. Organized by Maryvone M. Gomes, Jan/2011.

As festas do ciclo junino representam a mudança de estação climática e o início do ciclo da fartura ou colheita. Momento de celebração e agradecimento pela colheita, em que muitos relembram as suas origens, através das danças, das comidas típicas e dos rituais. Como confirma (Lévi-Strauss, 1983), "a comemoração é à volta as origens e consequentemente a consciência da História". As festas juninas procuram referenciar três santos católicos: Santo Antônio, São João Batista e São Pedro.

Em Fortaleza muitos são os bairros que celebram as festas de São João ${ }^{5}$, e que acabaram deixando o formato de "festa para brincar quadrilha" e passaram para o formato competitivo dos festivais e arraiás. Algumas das festas distribuídas por Fortaleza destacam-se pelos festivais tradicionais de quadrilhas, como o Arraiá da Cumade Chica no bairro José Walter, Vila São João no bairro Conjunto Ceará, Arraiá do Cumpadre Rogério no bairro Amadeu Furtado, Festival de Quadrilhas do Grande Bom Jardim no bairro Bom Jardim, Festival de Quadrilhas do Bairro Ellery no bairro Ellery, Festival São Mateus no bairro Nossa Senhora das Graças, Arraiá do Cumpadre Kiko no bairro Monte Castelo, entre outras festas.

Para entender como as festas nos municípios da região metropolitana, se mantêm visível diante da diversidade cultural do Estado é importante penetrarmos na temática da "tradição inventada" de Eric Hobsbawm (1984), que sintetiza:

Por "tradição inventada" entende-se um conjunto de práticas, normalmente reguladas por regras tácita ou abertamente aceitas; tais práticas, de natureza ritual ou simbólica, visam inculcar certos valores e normas de comportamento através da repetição, o que implica, automaticamente; uma continuidade em relação ao passado. 
Consideramos aqui tanto as "tradições" institucionalizadas, na perspectiva do patrimônio cultural, quanto as que são reconhecidas popularmente assim, mesmo sem um longo período de tempo para cristalizá-las. Nesse sentido a invenção de tradições é essencialmente um processo de formalização e ritualização caracteriza-se por referir ao passado, mesmo que apenas pela imposição da repetição. (HOBBAWM; RANGER, 1984)

As tradições antes rígidas tornam-se obsoletas diante da modernização das técnicas, e pela incapacidade de adaptar-se deu origem às "novas" tradições. Certeau em sua obra - A Invenção do Cotidiano (1994), mostra que "o homem ordinário" inventa o cotidiano escapando silenciosamente a essa conformação da racionalidade técnica, com práticas culturais contemporâneas, recuperando as astúcias anônimas das artes de fazer numa sociedade de consumo.

Já Canclini (1989), que também aborda essa perspectiva, sugere a reformulação do "popular" constituído por processos híbridos e a modernização das práticas. O autor acredita que o objeto "puro" e "autêntico" não garante a reprodução e o benefício local. Concordamos com Canclini, pois nas observações de campo das festas pesquisadas, formas criativas foram incorporadas a festa na tentativa de um retorno positivo para a comunidade local, e nessa perspectiva as encenações ganharam novos espaços e se multiplicaram na busca por novas identidades.

Os levantamentos de campo do ciclo junino também privilegiaram as festas em Fortaleza, RMF e algumas cidades do interior do Estado, nos meses de junho e julho de 2011 (Quadro 3).

Quadro 3: calendário de atividades de campo - ciclo junino.

Table 3: schedule of field activities - "Junino" Cycle.

\begin{tabular}{|l|c|c|}
\hline \multicolumn{2}{|c|}{ Pesquisa do Ciclo Junino - Equipe Ceará Pró-Cultura } \\
\hline \multicolumn{1}{|c|}{ FESTA } & LOCAL & DATA \\
\hline Festival Junino & $\begin{array}{c}\text { Conjunto Ceará - Fortaleza/ } \\
\text { CE }\end{array}$ & $\begin{array}{c}04 / 06,17 / 06 \text { e } \\
22 / 06 / 11\end{array}$ \\
\hline Festa do Pau da Bandeira & Barbalha/CE & 12 e $13 / 06 / 2011$ \\
\hline Arraiá da Cumade Chica & José Valter - Fortaleza/CE & $25 / 06 / 11$ \\
\hline Festa de São Pedro & Mucuripe- Fortaleza/CE & $29 / 06 / 11$ \\
\hline $\begin{array}{l}\text { Festival de Quadrilhas do Cumpade } \\
\text { Rogério }\end{array}$ & Parque Araxá - Fortaleza/CE & $29 / 06 / 11$ \\
\hline São João de Maracanaú & Maracanaú/CE & $04 / 07$ e 13- \\
& & $107 / 2011$ \\
\hline Festa de Nossa Senhora do Carmo & Centro - Fortaleza/CE & $11 / 07$ e 16/07/11 \\
\hline Festa de Sant'Ana & Jaguaruana/CE & 15 A 18/07/11 \\
\hline $\begin{array}{l}\text { Festa do Centenário de Juazeiro - } \\
\text { Romaria }\end{array}$ & Juazeiro do Norte/CE & $20 / 07 / 11$ \\
\hline
\end{tabular}

Fonte: Jornais O Povo e Diário do Nordeste. Organizado por Maryvone M. Gomes, Ago/ 2011. Source: Journals "O Povo" and "Diário do Nordeste". Organized by Maryvone M.Gomes, Aug/2011. 
Nos levantamentos de campo do ciclo junino é notória a intensa atividade festiva junina em todo ciclo e por todo Estado do Ceará. Algumas festas aqui cadastradas, apesar de estarem localizadas no período do ciclo junino, não possuem nenhuma ligação direta com a tradição junina. São exemplos as festas das padroeiras Nossa Senhora do Carmo e Sant'Ana, e a homenagem ao Centenário de Juazeiro.

Das festas juninas nos terreiros aos festivais de quadrilhas mais estilizados, esses eventos mudam o cotidiano das cidades metropolitanas, especialmente nordestinas, que nesse período festejam os santos juninos. A incorporação de novas técnicas de produção e de grandes estruturas nesses eventos é uma preocupação dos organizadores na perspectiva de torná-los mais atrativos para o turista.

\section{A festa de Nossa Senhora da Conceição em Pacatuba (CE)}

Os lugares festivos estabelecem as relações simbólicas e de valores culturais, constituindo a identidade e o sentimento de pertença de um indivíduo ou um grupo. É através das relações vivenciadas no lugar simbólico das festas de Nossa Senhora da Conceição, que iremos compreender a construção das identidades dos lugares e das identidades das pessoas (ROSENDAHL, 2005).

O espaço pensado como "lugar festivo" permite entender o sentido de lugar e do evento festivo, que para Ferreira (2003) é definido pelos discursos sobre suas significações e os valores simbólicos de quem faz a festa. Desta maneira, o lugar festivo se constitui como uma instituição discursiva que, através das narrativas trazidas pelos os envolvidos nesses festejos, define uma maneira de se conceber o patrimônio de um lugar.

A investigação da construção simbólica desses lugares possibilitou a aproximação do objeto de estudo aqui proposto enquanto festa popular e a construção patrimonial do lugar, que vem ganhando importante destaque nas dinâmicas das cidades metropolitanas. E mesmo as festas que acontecem nas cidades no entorno dos grandes centros urbanos, marcam presença pela pluralidade de sentimentos por elas criada, como sentimento de pertencimento, fé, devoção, recriação e ritualização, permitindo que as especificidades locais sejam vistas e sentidas de forma mais aparente.

O lugar festivo se assemelha o que seria um "espaço de celebração"6 proposto por Maffesoli, quando o autor trata esses espaços como

[...] lugares e espaços de socialidade, mistura de afetos e de emoções comuns, consolidados pelo cimento cultural ou espiritual, em suma, existem por e para as tribos que neles escolheram seu domicílio (MAFFESOLI, 2004, p.59).

Esses espaços possuem um forte componente estético, de contemplação, de teatralização e do lúdico, onde o conjunto que delimita o imaginário social. É o conjunto que 
faz da cidade o "altar" privilegiado da estética integrada (MAFFESOLI, 2004, p.74). O espaço de celebração se confunde com a própria festa, pelo culto a estética e pela forma lúdica de festejar desde sua origem, e se multiplicam pelas cidades, como celebração ao corpo, a imagem, a amizade, a comida, entre outros.

O município de Pacatuba (Figura 1) festeja há 141 anos sua padroeira, momento muito esperado pelos pacatubanos durante todo ano. Os festejos iniciam no dia 28 de Novembro e transcorre até o dia 08 de Dezembro. A data coincide com o ano de sua emancipação política, antes pertencente à Maranguape. A igreja matriz de Pacatuba localiza-se na sede de Pacatuba, próximo de órgãos da administração municipal, da Praça Francisco das Chagas Albuquerque - popularmente conhecida como Praça da Matriz e da Praça da Paixão. E considerada como ponto de referência, tanto cartográfica pela centralidade, como pela beleza exuberante, pois fica na subida da Serra da Aratanha e do balneário das Andréa compondo uma paisagem singular.

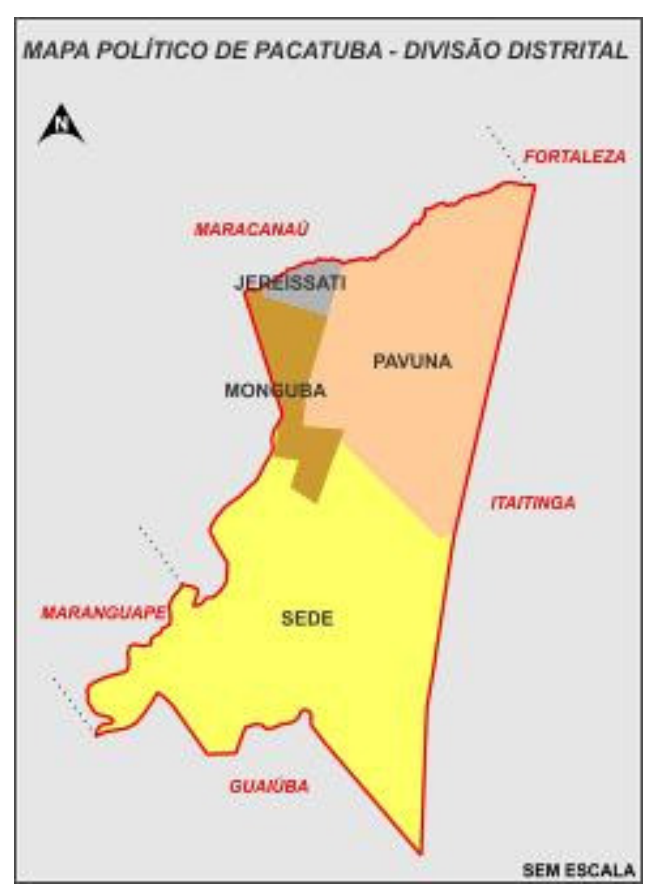

Figura 1: Mapa de divisão política de Pacatuba (CE). Fonte: IBGE. Organizado por Maryvone M. Gomes, Abril/2011.

Figure 1: Map of the political division of Pacatuba (CE). Source: IBGE. Organized by Maryvone M. Gomes, April/2011.

As festas de padroeiros assim como outras festas religiosas ocorrem em um tempo sagrado, momento vivido pelo homem religioso, como destaca Eliade (2001, p.64):

[...] A cada festa periódica reencontra-se o mesmo tempo sagrado aquele que se manifesta na festa do ano precedente ou na festa de há um século: é o tempo criado e santificado pelos deuses por ocasião de suas gestas que são justamente reatualizadas pela festa 
As festas de Nossa Senhora da Conceição e a encenação da Paixão de Cristo: os desafios ao lugar do patrimônio imaterial e turístico em Pacatuba (CE)

Neste reencontro do tempo sagrado nas festas de padroeiros, o devoto ratifica sua promessa e se sente mais próximo do seu "santo", através dos rituais próprios do momento, como novenas, procissões e missas que reatualizam a fé do povo.

Durante a festa o cotidiano da cidade é transformado em espaço festivo incorporando novas práticas. A tranquilidade de Pacatuba é quebrada nos dias da festa, em especial a festa da padroeira. A movimentação começa uma semana antes da festa da padroeira, quando começa a novena, todas as noites os religiosos se reúnem na igreja para a celebração. A novena atrai tanto moradores de Pacatuba, como de municípios vizinhos, em sua maioria, idosos. O comercio é aquecido nesse período com a montagem de barracas no entorno da Praça da igreja para venda de produtos artesanais, religiosos, comidas típicas e entretenimento em geral. Sobre a relação entre festa e espaço, Maia conclui que:

Grande parte das festas, no seu momento de ocorrência, simplesmente fornece nova função às formas espaciais prévias que dispõem para a realização (ponto central e entorno): ruas, praças, terrenos baldios, estádios de futebol transformam-se em palcos para o evento (MAIA, 1999, p. 204).

O cortejo percorre desde a entrada da cidade até a igreja matriz (Figuras 2 e 3 ), durante percurso louvores e rezas convidam os moradores para a celebração. A praça, que no cotidiano do lugar é espaço de encontro dos cidadãos de Pacatuba, nesse momento torna-se um lugar do grande espetáculo. Efeitos de som, iluminação, teatralização, ritualização do evento fizeram com que os festejos em homenagem a padroeira de Pacatuba adquirissem condição de "espetáculos".
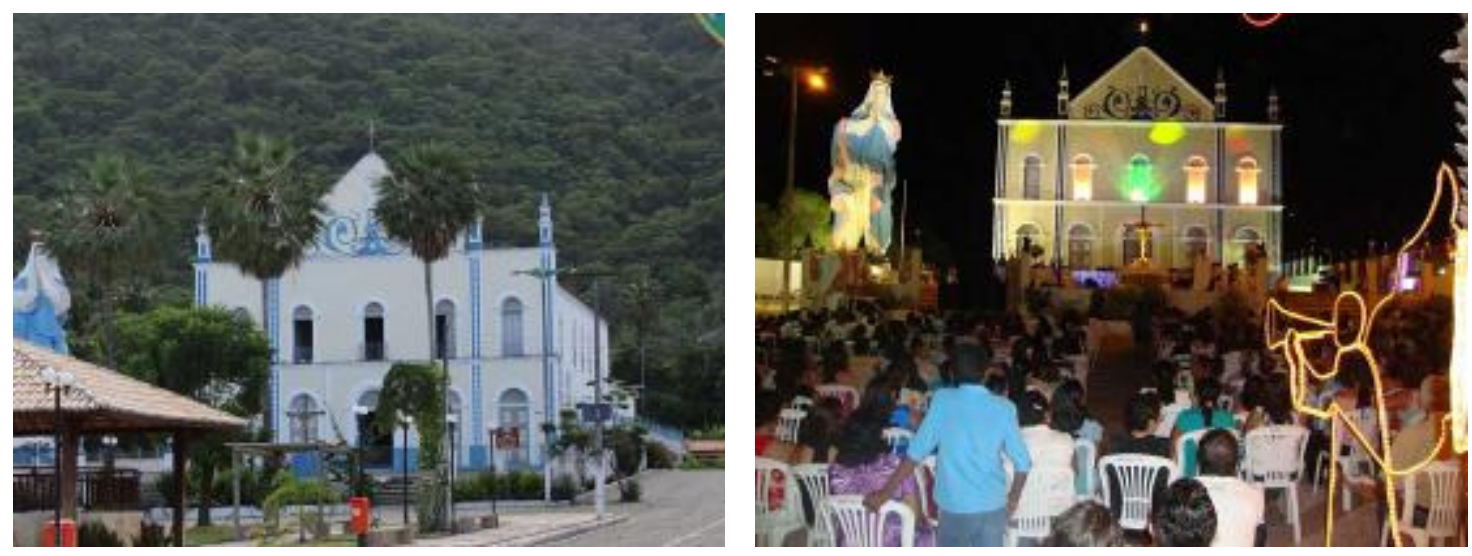

Figuras 2 e 3: igreja de Nossa Senhora da Conceição.

Fonte: Acervo de Maryvone M. Gomes, 2010.

Figures 2 and 3: Church of Nossa Senhora da Conceição.

Source: Collection of Maryvone M. Gomes, 2010. 
Dentro dessa perspectiva da realidade das festas que adquiriram formato de espetáculos, Trigueiro (2005) nos lembra com muita propriedade, "a espetacularização das culturas populares não é uma coisa tão nova como se pensa, a mudança é nos métodos de produção, na velocidade da distribuição e no mercado de consumo desses bens culturais". A mudança é gradativa, a partir das novas invenções incorporadas a esses espaços culturais.

A espetacularização das festas aqui apresentadas pode ser considerada como forma de se fazerem presentes diante das realidades festivas, gerando possivelmente uma demanda de turismo e lazer ao lugar. Porém, detectamos nas observações de campo, que a maior parte de participantes da festa de Nossa Senhora da Conceição são moradores da sede de Pacatuba ou dos distritos. Poucos registros de visitantes dos municípios vizinhos.

Essa realidade das festas cíclicas que se estabelece nos ambientes metropolitanos, e sugerem esse formato de espetáculo com tal refinamento, merecem maior aprofundamento do conhecimento científico das espacialidades festivas.

\section{A Festa da Paixão de Cristo em Pacatuba}

O espetáculo da Paixão de Cristo encenado há 38 anos é pioneiro em encenações dessa natureza no Ceará. O evento teve origem em 1974, quando o Padre Edilson encenou a Via Sacra pelas ruas da cidade, com o objetivo de movimentar a cidade. A igreja encontrou uma forma criativa de aproximar-se do povo, sobretudo contar a vida de Cristo em forma de espetáculo, promovendo assim interações entre a igreja e o povo, ou seja, entre o templo-mundo. Como bem dizia Maia (2010, p. 90 e 91) em suas pesquisas e observações,

[...] temos notado que essa ressantificação do mundo na sua totalidade é bastante expressiva em dias de festa, quando se promovem interações espaciais ritualizadas "templo-mundo" e vivenciadas com emoção, permitindo-nos demolir fronteiras tão prontas entre espaço sagrado e profano.

As doze estações foram encenadas utilizando de quadros colocados nas residências, e o Cristo acompanhava o Padre nas estações da via Sacra até a igreja. Dois anos após a criação da Via Sacra, o Sr. Antony Fernandes artista plástico e morador de Pacatuba, decidiu ajudar na produção. E pediu ao pároco que levasse os quadros para dentro da igreja, para que ele pudesse fazer um teatro mais abrangente, um trabalho diferente ${ }^{7}$.

Nesse momento a igreja perde espaço na realização da Via Sacra, deixando de realiza-la, passando essa competência ao Sr. Antony com o apoio da Prefeitura de Pacatuba. A igreja continuou com a programação religiosa na Semana Santa, mas deixou de participar mais efetivamente da encenação da Paixão de Cristo.

Cabe ratificar que a encenação da Paixão de Cristo em Pacatuba é uma festa 
de referencial religioso, não eminente católica, pois é aberta a qualquer religião. Porém é religiosa na sua forma de encenar a vida de Cristo e de passar uma mensagem cristã, e não religiosa na substância, por ser um espetáculo teatral na pressa de constitui-se como festa moderna, atendendo as necessidades dos produtores.

Nesse sentido, algumas festas cíclicas extravasam ou antecipam seu ciclo festivo, favorecidas pela flexibilidade com que as festas transitam pelos ciclos. $\mathrm{O}$ exemplo disso à encenação da Paixão de Cristo em Pacatuba, que adquiriu formato e técnica de grande espetáculo, e guiado pela força midiática, reposicionou no calendário festivo no sentido da antecipação do ciclo junino. Esse "Junino" do seu lugar se justifica por uma antecipação, dada pela força midiática, que o evento da paixão tomou. É a festa que introduz o ciclo junino nos circuito das grandes festas desse ciclo.

$\mathrm{Na}$ tentativa de reinventar o Sr. Antony Fernandes teve a ideia de encenar de forma criativa a via sacra em 1976. O idealizador montou a Via Sacra de forma artesanal, utilizando de material que dispunha e contando com a colaboração dos moradores que serviam de atores para encenar pelas ruas da cidade de Pacatuba. O cortejo saía da Igreja Nossa Senhora do Carmo seguindo pelas ruas da cidade, encenando doze passagens utilizando como cenário as frentes das residências. "A gente pedia que os donos das casas cedessem às frentes para que nós pudéssemos colocar as cortinas, uma coisa, um jarro de planta", declaração do Sr. Antony em entrevista ao site da prefeitura de Pacatuba.

No espetáculo da Paixão de Cristo que encena uma passagem religiosa, o sagrado e o profano estão imbricados. Como bem diz Cavalcante (2009) é uma profanidade que espetaculariza o sagrado, sem dessacralizá-lo. Ambas as encenações teatrais procuram a cada edição tornarem-se mais profissionais na produção desse espetáculo, mantendo o sagrado nas cenas do espetáculo que remetem a vida de Cristo.

Com o passar dos anos o aumento no público foi progressivo. Grande parte do público era proveniente do entorno de Pacatuba e de parentes que retornavam à cidade natal durante semana santa. A comunicação através da "propaganda de boca em boca" ajudou na divulgação da encenação e atraiu curiosos de diversas localidades. O percurso longo e cansativo, fez com que a população reivindicasse aos organizadores que a Via Sacra fosse para um espaço fixo, com acomodações e infraestrutura adequadas.

Foi construída a Praça da Paixão estrategicamente posicionada no epicentro das atividades sociais e importantes equipamentos da sede do município: a igreja de Nossa Senhora da Conceição, Praça da igreja matriz e sede da prefeitura (Figuras 4 e 5).

A Praça é utilizada quase exclusivamente para o espetáculo da Paixão de Cristo, o que denota sua importância na construção da identidade com o lugar e a carga simbólica para o reconhecimento do espetáculo e visibilidade de Pacatuba. O espaço da Praça da Paixão é subutilizado no restante do ano, com eventos esporádicos religiosos ou não. Existe interesse dos gestores municipais em transformar o espaço da Praça da Paixão em museu, caso o espetáculo seja transferido para outro espaço. 


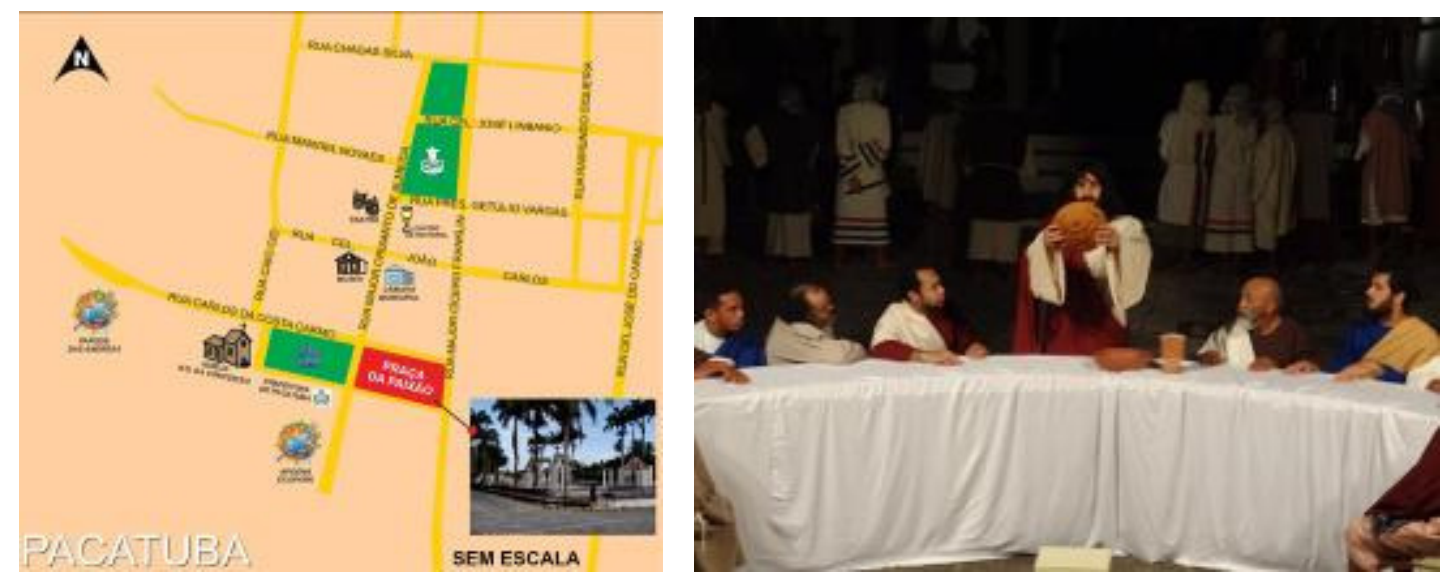

Figuras 4 e 5: localização e cena da paixão de cristo 2011.

Fonte: Google Earth 2011. Organizado por Gláumer F. de Sousa e Maryvone M. Gomes, 2012.

Figures 4 and 5: location and scene from the Passion of Christ in 2011.

Source: Google Earth 2011. Organized by Gláumer F. de Sousa and Maryvone M. Gomes, 2012

Quando pensamos a Encenação da Paixão de Cristo em Pacatuba como lugar, consideramos não só as materialidades, mas também as imaterialidades através da representação simbólica que compõem o cenário e revelam a dimensão do vivido durante aquele tempo sagrado (COSTA, 2001, p 29). As manifestações culturais, representada nesse estudo pela festa, irão construir a identidade do lugar, onde o habitante se reconhece como parte integrante do lugar. O sentimento de pertença está relacionado à aproximação e à ligação com o local de origem. É o sentimento de enraizamento, em que o indivíduo constrói e é construído, planeja e se sente parte de um projeto, modifica e é por ele modificado.

O espetáculo produzido com grande aparato técnico exigiu da Prefeitura Municipal de Pacatuba mais verba para manter grandiosa estrutura. Assim foi criada a Organização da Sociedade Civil de Interesse Público - OSCIP ${ }^{8}$ Serra da Paixão permitindo que as doações realizadas por empresas possam ser descontadas no imposto de renda.

O Ponto de Cultura foi implantado em $2008 \mathrm{com}$ a finalidade de capacitar os atores para a encenação da Paixão de Cristo, para filmes ou outros espetáculos. O ponto de cultura faz parte de um programa do Ministério da Cultura - MAIS CULTURA, que prevê repasse de $R \$ 180.000$ aos contemplados com o edital em até três anos. Em entrevista (16 de abril de 2011) com o vice-presidente da Secretaria de Turismo e Cultura, Luiz Emanuel Pereira Monteiro declarou: "O programa vem fortalecer o que já existe, essa é a filosofia do programa, surgiu da necessidade de capacitar os atores que já participavam da Paixão de Cristo e que não tinham nenhuma capacitação". O espetáculo atualmente conta com 200 pessoas entre atores e figurantes. Ao todo são 300 pessoas entre técnicos de montagem, luz e som, apoio, produção, montagem, bilheteria, segurança, equipe médica, produzindo em torno de 200 empregos informais indiretos.

A Secretaria de Turismo e Cultura de Pacatuba financia a maior parte dos gas- 
tos na produção do espetáculo, a iniciativa privada entra com uma pequena parcela $\mathrm{e}$ a própria SECULT com outra parcela via folha estadual da Cultura. No espetáculo de 2011 foi gasto pela Prefeitura de Pacatuba em torno de 200 mil reais para a realização de dois dias de evento, e contou ainda com doações de empresas instaladas no município, sem auxilio da Lei Rouanet ${ }^{9}$. Conforme entrevista com Emanuel Monteiro vice-presidente da Secretaria de Turismo e Cultura:

[...]Nunca conseguimos captar ajuda para o espetáculo via Lei Rouanet. A lei Rouanet permite que o empresário decida o que ele quer apoiar, então o empresário apoia o que para a marca deles é rentável. O espetáculo da Paixão não tem atores globais, nem grandes nomes, que façam também com que as empresas se motivem. Não tem o oIhar comercial, apenas artístico.

Nesse sentido o poder político na figura da prefeitura e do Estado via SECULT, é vista como instituição gestora desses recursos de maior competência do que os agentes de mercado, e aposta no que pode dar retorno mais imediato.

A incorporação de novas técnicas de produção e de grandes estruturas nesses eventos é uma preocupação dos organizadores na perspectiva de torná-los mais atrativos para o visitante e assim poder proporcionar para a cidade uma maior visibilidade.

Essas duas festas são exemplos de festas metropolitanas espetaculares dentre tantas outras que se modernizaram na busca de atender interesses midiáticos, políticos e econômicos. Notadamente, o formato espetacular dessas festas não proporciona uma significativa demanda de turismo, possivelmente devido a proximidade de $\mathrm{Pa}$ catuba com o município de Fortaleza, ou por razão do calendário do evento não dispor de outras opções de lazer. São suposições levantadas em campo que cabe pesquisa mais apurada para elucidar.

\section{Algumas conclusões}

O quadro que se observa na análise das festas locais, na abertura de seus respectivos ciclos (natalino e pascal/junino) aponta para a condição de "espetáculo urbano" em evolução. A dinâmica festiva das tradições cristãs modernizadas produz um campo de forças predominantemente de natureza mítica (religiosa) na festas de N. S. da Conceição e midiática (mídia) na Encenação da Paixão de Cristo, estabelecendo assim um confronto dos aspectos simbólicos com diferentes interesses políticos e econômicos.

As festas estudadas são exemplos de festas metropolitanas espetaculares que se modernizaram na busca de atender interesses midiáticos, políticos e econômicos, predominantemente. As imagens e os discursos capturados nessa primeira fase demonstram, a título de conclusão, que a construção de espetáculos para festividades tradicionais metropolitanas não rompe o processo de invisibilidade relativa dos eventos. O que dificulta assim uma gestão integrada do turismo e um desafio efetivo no 
desenvolvimento da educação patrimonial, com ênfase nos bens imateriais, notadamente os eventos festivos.

A título de colaboração com o aprofundamento da discussão em novas oportunidades de estudo, o fortalecimento dessa visibilidade deve passar por um conjunto de sugestões mais articuladas na escala metropolitana; seja na divulgação cultural, seja na interiorização do turismo regional cearense. Tendo em vista o enfoque propositivo destacamos preliminarmente quatro sugestões desse conjunto:

- A divulgação dos demais eventos festivos de Pacatuba, (Festa da Padroeira, festival de quadrilhas juninas, Saberes e Sabores, carnaval, etc.) durante a realização da Paixão de Cristo, promovendo o marketing turístico mais integrado;

- A composição de acordos com o setor de transporte para visitas à Serra da Aratanha e Trilhas ecológicas, Roteiro histórico, proporcionando também a integração das dimensões cultural e natural/ambiental;

- A gestão de uma política de encontro interestadual, considerando outros municípios no Estado que possuem encenação da Paixão e podem ajustar parcerias no aperfeiçoamento do evento;

- O incentivo a rede educacional para que o modelo de encenação possa acolher outros "autos" (manifestações da teatralização popular) ao longo do ano, inclusive com temáticas do ciclo natalino iniciadas na festa da padroeira.

Essas foram algumas proposições levantadas nesse estudo para um futuro aprofundamento nas discussões sobre as festas e as relações simbólicas, políticas, econômicas e turísticas tecidas em Pacatuba/Ceará.

\section{Referências bibliográficas}

AMARAL, R.C.M.P. Festa à Brasileira: significados do Festejar no país que não é sério. Tese de Doutoramento em antropologia. Departamento de Antropologia da Faculdade de Filosofia, Letras e Ciências Humanas - USP, 1998.

BAKHTIN, M. A cultura popular na Idade Média e Renascimento: o contexto de Rabelais. São Paulo: UCITEC, 1987.

BRANDÃO, C.R. Prece e folia: festa e romaria. Aparecida, SP: Idéias \& Letras, 2010.

CANCLINI, N.G. Culturas Híbridas: Estratégias para entrar e sair da modernidade. São Paulo: EDUSP, 1989.

CAVALCANTE, T.V.; OLIVEIRA, C.D.M. Entre o Cosmos e o Caos: A Dinâmica do Santuário Metropolitano de Fátima em Fortaleza - CE. Anais... XII Encontro de Geógrafos da América Latina - EGAL, 2009, Montevidéu. XII Encontro de Geógrafos da América Latina - Caminando en una América Latina en transformación. Montevidéu: Imprenta Gega, 2009. p. 124-124. 
As festas de Nossa Senhora da Conceição e a encenação da Paixão de Cristo: os desafios ao lugar do patrimônio imaterial e turístico em Pacatuba (CE)

CERTEAU, M. A invenção do cotidiano: 1, Artes de fazer. Petrópolis: Vozes, 1994.

CLAVAL, P. A geografia cultural. Florianópolis: Editora da UFSC, 1999.

CLAVAL, P. As abordagens da geografia cultural. In: CASTRO, I.E. et al. (orgs). Explorações geográficas: percursos no fim do século. Rio de Janeiro: Bertrand Brasil, 1997.

COSTA, O.J.L. Região e Paisagem: a sacralidade da natureza no sertão central do Ceará. Revista Espaço e Cultura. Rio de Janeiro: UERJ, no 28, p. 48, 2010.

COSTA, O.J.L. Hierópolis: o significado dos lugares sagrados do sertão cearense. In: ROSENDAHL, Z. (org). Geografia cultural: Trilhas do Sagrado. Rio de Janeiro: EdUERJ, 2010, p. 35-60.

COSTA, O.J.L. Icó: patrimônio cultural no semi-árido cearense. Propostas Alternativas: Memória e Patrimônio Cultural do Ceará - I, IMOPEC. Fortaleza, 2001.

DEL PRIORE, M. Festas e Utopias no Brasil Colonial. São Paulo: Brasiliense, 2000.

DI MÉO, G. La Geógraphie en fête. Paris: Ed. Geophrys, 2001.

DUVIGNAUD, J. Festas e Civilizações. Fortaleza: Universidade Federal do Ceará, 1983, p. 236.

ELIADE, M. O sagrado e o profano: A essência das religiões. São Paulo: Martins Fontes, 2001.

FERREIRA, L.F. O lugar festivo: a festa como essência espaço-temporal do lugar. Espaço e Cultura, Rio de Janeiro, v. 15, p. 7-21, jan./jun. 2003.

GOMES, P.C.C. Cenários para a Geografia: Sobre a espacialidade das imagens e suas significações. In: ROSENDAHL, Z.; CORRÊA, R.L. (Org.). Espaço e Cultura: pluralidade temática. Rio de Janeiro: EDUERJ, 2008

HOBSBAWM, E.; RANGER, T. A invenção das tradições. Rio de Janeiro: Paz e Terra, 1984, p. 9-23.

LÉVI-STRAUSS, C. O pensamento selvagem. São Paulo: Nacional, 1976.

MAIA, C.E.S. Ritual e emoção nas interações espaciais: repensando o espaço sagrado nas festas populares de romarias e folguedos (notas introdutórias). In:. ROSENDAHL, Z. (org.). Trilhas do Sagrado. Rio de Janeiro, EDUERJ, 2010.

MAIA, C.E.S. Ensaio interpretativo da dimensão espacial das festas populares: Proposições sobre festas brasileiras. In: ROSENDAHL, Z. (org.). Manifestações da cultura no espaço. Rio de Janeiro: EDUERJ, 1999, p. 191-218.

MAFFESOLI, M. Notas sobre a pós-modernidade: O lugar faz o elo. Rio de Janeiro: Ed. Atlântica, 2004.

MORIN, E. As Culturas de Massas no século XX: Neurose. Rio de Janeiro: Forense Universitária. 2002.

OLIVEIRA, C.D.M. Desafios contemporâneos das cidades-santuários no Estado do Ceará (Brasil): políticas patrimoniais e diocesanas. Geosaberes, Fortaleza, v. 1, n. 1, p. 37-51, maio/2010a. 
OLIVEIRA, C.D. et al. Festas Populares Religiosas e suas Dinâmicas Espaciais. REVISTA Mercator, ano 06, número 11, 2007, p. 25 - 26.

OLIVEIRA, C.D. Geografia do Turismo na Cultura Carnavalesca: O Sambódromo do Anhembi. São Paulo: Paulistana, 2007.

RAHDE, M.B.F. Considerações sobre uma estética contemporânea. Revista da Associação Nacional dos Programas de Pós-Graduação em Comunicação. Abril de 2007.

ROSENDAHL, Z. (Orgs.). Geografia: temas sobre cultura e espaço. Rio de Janeiro: EdUERJ, 2005.

SOUSA, G.F. Mapa de localização da Praça da Paixão equipamentos urbanos em Pacatuba (CE). Fortaleza, 2012. Sem escala.

TRIGUEIRO, M.O. Seminário Nacional de Políticas para a Cultura Popular. Painel: Culturas Populares, Circuitos de Difusão de Mercados, 2005.

TUAN, Yi-Fu. Space and Place: Humanistic Perspective. In: GALE, S.; OLSSON, G. (eds.). Philosophy in Geography. Dordrecht, Reidel Publ. Co., p. 387 - 427, 1979.

\section{Notas:}

${ }^{1} \mathrm{O}$ presente artigo é produto do projeto de pesquisa financiado pela CAPES e pelo Ministério da Cultura, através do edital Pró-Cultura/2009, intitulado "A Dimensão territorial das festas populares e do turismo: estudo comparativo do patrimônio imaterial em Goiás, Ceará e Sergipe", desenvolvido pela rede: Programa de Pós-Graduação em Geografia da UFC, Laboratório de Estudos e Pesquisas das Dinâmicas Territoriais - LABOTER e Programa de Pós-Graduação em Geografia do Instituto de Estudos Sócio-Ambientais da UFG e Núcleo de Pós-Graduação em Geografia da UFS.

${ }^{2}$ O Ciclo da Páscoa ou Pascal divide-se em Quaresma, Semana Santa e Tempo Pascal. O tempo pascal momento da Festa da Páscoa ou da Ressurreição do Senhor, se estende por cinquenta dias entre o domingo de Páscoa e o de Pentecostes, comemorando a volta de Cristo ao Pai na Ascensão, e o envio do Espírito Santo. Disponível em: <http:// catholicum.wikia.com/wiki/Ano_litúrgico>. Acesso em: 20 de outubro de 2011.

${ }^{3}$ O Ciclo do Natal ou Natalino se divide em Advento e Tempo do Natal. Nesse ciclo são celebradas as festas da Sagrada Família, de Maria, mãe de Jesus e do Batismo de Jesus. O Tempo do Advento é o momento de preparação para a vinda de Cristo, iniciam-se quatro domingos antes do Natal e termina no dia 24 de Dezembro, desembocando na comemoração do nascimento de Cristo. Esse tempo cristão vai da véspera do Natal de Nosso Senhor até o domingo depois da festa da Epifania, em que se comemora o Batismo de Jesus. Disponível em: <http://catholicum.wikia.com/wiki/Ano_litúrgico>. Acesso em: 20 de outubro de 2011.

${ }^{4} \mathrm{O}$ Tempo Comum é um período sem grandes acontecimentos para a igreja católica, é o momento que a igreja chama de acolhimento da palavra de Deus. Disponível em: <http:// catholicum.wikia.com/wiki/Ano_litúrgico>. Acesso em: 20 de outubro de 2011.

5 As Festas de "São João" é o termo utilizado popularmente nas festa /quadrilhas do ciclo junino.

${ }^{6}$ Da obra de Michel Maffesoli, Notas sobre a pós-modernidade: o lugar faz o elo. O autor aborda o poder dos espaços de celebração nas megalópoles, onde no sentido religioso do ter- 
mo são celebrados diversos cultos com forte coeficiente estético-ético. São as celebrações do corpo, do sexo, da imagem, da amizade, da "comédia", do esporte... (MAFFESOLI, 2004, p. $57)$.

${ }^{7}$ Trechos referentes à entrevista do Sr. Antony ao site da Prefeitura Municipal de Pacatuba, disponível em http://www.pacatuba.ce.gov.br.

${ }^{8}$ Organização da Sociedade Civil de Interesse Público ou OSCIP é um título fornecido pelo Ministério da Justiça do Brasil, cuja finalidade é facilitar o aparecimento de parcerias e convênios com todos os níveis de governo e órgãos públicos (federal, estadual e municipal) e permite que doações realizadas por empresas possam ser descontadas no imposto de renda. OSCIPs são ONGs criadas por iniciativa privada, que obtêm um certificado emitido pelo poder público federal ao comprovar o cumprimento de certos requisitos, especialmente aqueles derivados de normas de transparência administrativas. Em contrapartida, podem celebrar com o poder público os chamados termos de parceria, que são uma alternativa interessante aos convênios para ter maior agilidade e razoabilidade em prestar contas, disponível em http:// www.alfabrasil.org.br.

${ }^{9}$ A Lei Federal de Incentivo à Cultura (Lei no 8.313 de 23 de dezembro de 1991), conhecida também por Lei Rouanet, é a lei que institui politicas públicas para a cultura nacional, como o PRONAC - Programa Nacional de Apoio à Cultura, disponível em http://www.planalto.gov.br.

Maryvone Moura Gomes: Universidade Federal do Ceará, Fortaleza, CE, Brasil.

Email: maryvone@gmail.com

Link para o currículo Lattes: http://lattes.cnpq.br/3713902874688071

Christian Dennys Monteiro de Oliveira: Universidade Federal do Ceará, Fortaleza, CE, Brasil.

Email: cdennys@ufc.br

Link para o currículo Lattes: http://lattes.cnpq.br/6672867433887720

Data de submissão: 10 de junho de 2012

Data de recebimento de correções: 18 de junho de 2013

Data do aceite: 01 de julho de 2013

Avaliado anonimamente 


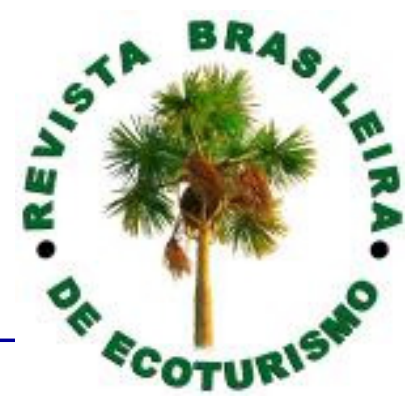

\title{
Vale do Paraíso: a sustentabilidade de uma iniciativa endógena de turismo no espaço rural
}

\author{
Vale do Paraíso: the sustainability of an endogenous initiative of \\ tourism in rural space
}

\section{Bianca Pugen, Marcos Daniel Schmidt de Aguiar, Vera Lúcia Boeno de Oliveira}

\begin{abstract}
RESUMO
A pluriatividade no espaço rural pode ser uma alternativa de renda e de fixação dos residentes ao campo. Neste contexto, as atividades de agroindústria, artesanato e turismo podem contribuir para o desenvolvimento local e regional. Percebendo estas questões, realizou-se uma pesquisa para entender e analisar alguns aspectos relativos à sustentabilidade das atividades de turismo rural no roteiro denominado Vale do Paraíso, no município de Três Cachoeiras, Litoral Norte do Rio Grande do Sul. Para tanto, foram utilizadas entrevistas abertas e estruturadas, onde os agricultores e representantes do poder público foram entrevistados e observação in loco. Como análise, tem-se que o roteiro Vale do Paraíso pode ser considerado um roteiro turístico de iniciativa tipicamente endógena. As questões culturais, ambientais e econômicas apontam para uma prática que vai ao encontro dos conceitos da sustentabilidade, embora alguns fatores mereçam atenção, como a necessidade de uma revisão da precificação do roteiro, a inexistência de uma sistematização para a educação ambiental e a falta de articulação e envolvimento do poder público municipal.
\end{abstract}

PALAVRAS-CHAVE: Turismo Rural; Endógeno; Sustentabilidade.

\section{ABSTRACT}

The pluriactivity in rural areas can be an alternative income and the setting of the camp residents. In this context, the activities of agribusiness, handicrafts and tourism can contribute to local and regional development. Realizing these issues, we carried out a survey to understand and analyze some aspects concerning the sustainability of rural tourism activities in script called Vale do Paraíso, at Três Cachoeiras, Northern Coast of Rio Grande do Sul. Therefore, interviews were open and structured, where farmers and government representatives were interviewed and on-site observation. As analysis is that the script Vale do Paraíso can be considered a tourist itinerary initiative typically endogenous. Cultural issues, environmental and economic point to a practice that meets the concepts of sustainability, although some factors deserve attention, such as the need for a review of the pricing of the script, the lack of a systematic environmental education and lack of articulation and involvement of municipal government.

KEYWORDS: Rural Tourism; Endogenous; Sustainability. 


\section{Introdução}

As transformações socioeconômicas das últimas décadas, decorrentes da globalização, foram visíveis em diversos setores da economia e também (ou principalmente) no campo. Para que se mantenham viáveis, as propriedades rurais necessitam de novas opções para a viabilização dos espaços rurais. Assim, a produção agrícola vem cedendo espaço para atividades não-agrícolas (OLIVEIRA, 1986).

A partir disso, alguns autores (KUBO; SOUZA, 2006; RODRIGUES, 1996; SABOURIN, 2007) propõem uma reflexão sobre pluriatividade no espaço rural como forma de produção alternativa, fenômeno que ultrapassa a presença de atividades padrão agrícolas agregando-se outras atividades. Por outro lado, o trabalho de Campanhola e Silva (2000) já detectava a perda de trabalhadores nas atividades eminentemente agrícolas:

O número de trabalhadores rurais e famílias dedicadas exclusivamente às atividades agrícolas vêm decrescendo rapidamente, acompanhado por um crescimento de trabalhadores rurais e famílias ocupadas em atividades não-agrícolas, isto é, unidades familiares em que nenhum membro está engajado em atividades agrícolas (CAMPANHOLA; SILVA, 2000. p.1).

Schneider (2006) também aponta esta questão, comentando a pluriatividade no meio rural como forma de gerar alternativas de renda para os residentes, através de outros afazeres que contribuam na diversificação de atividades desenvolvidas no campo.

Neste contexto, as atividades de agroindústria, artesanato e turismo podem contribuir para o desenvolvimento rural local e regional. Particularmente o turismo pode gerar renda, valorização cultural e social e, ainda, auxiliar na preservação do ambiente das propriedades que optarem por dedicar-se a esta atividade.

Para que apresente estes benefícios às propriedades rurais que se dedicam a atividade, há que se levar em conta questões relativas à sustentabilidade, nos seus variados âmbitos.

Pensar em sustentabilidade no meio rural pressupõe a realização de atividades que, ao mesmo tempo em que geram renda e diversificam economicamente as propriedades, estimulem sensos de pertencimento, promovam a cultura local, a qualidade de vida e ainda auxiliem na preservação do ambiente natural das localidades (SWARBROOKE, 2000).

Dentro desta problemática, realizou-se uma pesquisa para entender se as atividades de turismo rural em um município situado na região litorânea do Rio Grande do Sul são desenvolvidas de forma sustentável. A pesquisa buscou analisar algumas questões relativas à sustentabilidade econômica, cultural e ambiental das atividades de turismo rural no roteiro denominado Vale do Paraíso, no município de Três 
Pugen, B.; Aguiar, M.D.S.; Oliveira, V.L.B.

Cachoeiras, Litoral Norte do Estado. Roteiro este, desenvolvido por agricultores e que se configura no único roteiro de turismo rural certificado pela Secretaria de Estado do Turismo do Rio Grande do Sul (TURISMO, 2011).

\section{Contribuições do turismo para o desenvolvimento rural}

O fenômeno turístico movimenta bilhões de dólares por ano e pode envolver uma diversidade de serviços, profissionais e comunidades. Isto faz com que esta possa ser uma atividade rentável e competitiva, que, se planejada adequadamente, pode contribuir para o desenvolvimento sustentável dos municípios e de suas comunidades (HALL, 2001; MOLINA, 2005).

Nesta atividade a globalização também se fez visível quando organizações, poderes públicos e comunidades precisaram se adequar às transformações por ela exigidas. Em função disto, a segmentação de mercado foi uma das estratégias que surgiu para suprir as novas necessidades dos destinos receptores e do consumidor - turista.

Esta segmentação de mercado fez consolidar uma tipologia até então vivenciada em destinos turísticos consolidados, como alguns países da Europa: o turismo rural. Este tipo de turismo, no século XIX, era vivenciado apenas pela aristocracia, que tinha por hábito desfrutar das "residências campestres e de momentos de uma vida bucólica, num movimento denominado paisagismo" (REJOWSKI, 2002, p. 52). Nas últimas décadas tem sido desfrutado por um público maior e mais heterogêneo.

Para o Ministério do Turismo brasileiro, turismo rural é:

O conjunto de atividades turísticas desenvolvidas no meio rural, comprometidas com a produção agropecuária, agregando valor a produtos e serviços, resgatando e promovendo o patrimônio cultural e natural da comunidade (2008, p.18).

Percebe-se, neste conceito, alguns fatores importantes para a caracterização do segmento de turismo rural: produção agropecuária, patrimônio e comunidade. Portanto, para que a atividade seja denominada turismo rural, é importante que se mantenham as atividades primárias desenvolvidas nas propriedades (relacionadas ao cultivo), que preserve e propague seu patrimônio (natural, cultural, histórico e simbólico) e que envolva ativamente e de forma qualificada a comunidade.

Para Beni (2006) este tipo de turismo possibilita o desenvolvimento tanto dos residentes quanto dos turistas (ou visitantes em geral). Para o primeiro grupo, o desenvolvimento da oferta de serviços no meio rural surge como alternativa de aumento de renda, agregação de valor à propriedade e fixação do homem ao campo. Para o segundo pode ser uma forma de voltar às origens e de se reintegrar com o ambiente.

Assim, entende-se que a prática de turismo rural precisa estar relacionada à 
vivência no meio rural, sendo requisito fundamental para a prática desta atividade a relação com as atividades agrícolas. É importante que o residente não abandone suas atividades no campo, mas que se utilize disto como um atrativo em si, agregando valor a economia, valorizando a cultura local e melhorando as condições de vida da população.

De outra forma se avalia que o principal atrativo deste tipo de turismo é a peculiaridade dos distintos lugares e regiões e por isto esta atividade tende a ser viável em comunidades rurais de pequeno porte, justamente por ter o genuíno como atrativo principal. Isto expressa diferentes condições geográficas e territoriais dos lugares, a partir da cultura produzida pelas famílias de agricultores.

Os possíveis benefícios que o turismo rural possa trazer para o desenvolvimento regional podem ser constatados em diversas dimensões como a econômica, cultural e ambiental (há que se pensar também nos aspectos políticos, sociais e simbólicos, porém, para este estudo, as reflexões restringem-se aos três primeiros, dada as limitações de tempo e abrangência da pesquisa).

Economicamente, as atividades de turismo rural podem possibilitar a estabilização da população local no campo; a geração de rendas complementares; a contribuição para a reativação econômica de zonas deprimidas, além de outros aspectos decorrentes da atividade.

Em relação aos aspectos culturais, o turismo rural pode auxiliar a propagar a cultura local e regional; pode possibilitar a incorporação do trabalho remunerado da mulher; estimular e valorizar as atividades agropecuárias e artesanais. Ainda, pode provocar a manutenção e recuperação do patrimônio arquitetônico tradicional e aumentar o senso de pertencimento em relação ao local que habitam (VEZZANI, 2008; BARRETTO, 2005).

Quanto às questões relativas ao meio ambiente, a atividade pode ser um incentivo para que se preserve o ambiente local, sensibilizando os visitantes sobre cuidados com o meio natural. Neste sentido, as práticas de turismo rural precisam, além da educação ambiental, atentar para a capacidade de carga dos atrativos e para a criação de programas para reduzir a produção de resíduos, a fim de minimizar a destruição dos recursos renováveis.

A afirmação de Tulik (2003) ajuda a compreender melhor a contribuição do turismo para o desenvolvimento:

O turismo rural surgiu em meio a uma frágil economia [a agricultura] com o intuito de aumentar a renda dos agricultores e também de gerar empregos fazendo com que diminua o êxodo rural, havendo assim, o desenvolvimento local ou até mesmo regional com a atividade turística (TULIK, 2003, p.77).

A autora relaciona o turismo rural com o desenvolvimento local, assim como Campanhola e Silva (1999) o fazem, ao afirmar que o turismo no meio rural pode be- 
neficiar a comunidade como um todo, pois esta acaba compartilhando dos benefícios indiretos gerados, como melhoria de infra-estrutura e de serviços públicos.

Apesar de o turismo apresentar possibilidades de desenvolvimento, pode acarretar alguns impactos negativos, como especulação imobiliária, danos ambientais, superpopulação, hostilidade entre visitantes e visitados, descaracterização da cultura local, exploração econômica para fins políticos e outras interferências negativas decorrentes da falta de planejamento ou controle (BARRETTO, 2005).

Assim, como atividade complementar ou principal o turismo rural pode desenvolver cultural e economicamente comunidades locais e regiões, além de preservar o ambiente natural. Para que isto ocorra, é necessário planejamento e gestão adequada, que envolva os diferentes grupos sociais e que articule diferentes atores de maneira positiva.

\section{Sustentabilidade: uma questão endógena}

A sustentabilidade dos destinos turísticos rurais está para além de benefícios diretos para os agricultores. Sustentabilidade, para Rattner (1999), pressupõe democracia política, equidade social, eficiência econômica, diversidade cultural, proteção e conservação do meio ambiente, para toda a comunidade. Santos (2001) vai além, afirmando que desenvolvimento privilegiaria o ser humano na sua integralidade, possibilitando a construção plena da cidadania. Assim, as questões de crescimento econômico estariam articuladas às questões sociais, culturais, políticas, ambientais e às relações sociais de gênero e raça.

Desta forma, tem-se que desenvolvimento não é só crescimento econômico, embora este último seja importante para alcançar a sustentabilidade. No turismo, este conceito se aplica de forma importante, a partir do momento em que o turismo sustentável busca o desenvolvimento holístico tanto dos atores diretamente envolvidos no processo quanto do destino como um todo.

A Organização Mundial do Turismo (1998, p.21) entende como turismo sustentável aquele que satisfaz as necessidades presentes dos turistas ao mesmo tempo em que preserva as regiões de destino e incrementa novas oportunidades para o futuro. Deve ser concebido de modo a conduzir à gestão de todos os recursos existentes, tanto do ponto de vista da satisfação das necessidades econômicas, sociais e estéticas, quanto da manutenção da integridade cultural, dos processos ecológicos essenciais, da diversidade biológica e dos sistemas de suporte à vida (OMT, 1998, p. 21).

Neste sentido o turismo (e em particular o turismo rural) precisa articular todos os interessados direta e indiretamente na atividade: comunidade local, iniciativa privada, poder público e terceiro setor. O pleno envolvimento de todos os agentes que desempenham (ou deveriam desempenhar) papéis no fenômeno turístico é importante para que os benefícios sejam atingidos de maneira simétrica, justa e equilibrada (TOMAZZONI, 2002). 
Em algumas destinações, a iniciativa de realizar ou não a atividade turística é imposta pelo poder público, principalmente quando este percebe que o município possui atrativos que possam ser formatados para se transformarem em produtos turísticos. Ocorre que, como uma iniciativa exógena, muitas vezes a comunidade não se sente inserida no processo e pode não apropriar-se da atividade. Isto ocorrendo, torna -se difícil que a atividade atinja pleno desenvolvimento (KRIPPENDORF, 2000).

Já ao contrário, optando-se por uma iniciativa de organizar o turismo sendo endógena, isto é, partindo da comunidade, pode fazer com que os residentes tenham o senso de pertencimento fortalecido, o que é um ponto importante no desenvolvimento da atividade. Estas são iniciativas de base local, onde a comunidade e o empresariado local decidem sobre as questões relativas ao turismo.

Turismo comunitário ou de base comunitária pode ser definido como aquele onde as sociedades locais possuem controle efetivo sobre seu desenvolvimento e gestão. E por meio do envolvimento participativo desde o início, projetos de turismo devem proporcionar a maior parte de seus benefícios para as comunidades locais (WWF, 2001, p.2).

Cabe destacar o papel do poder público nas duas maneiras citadas, principalmente por ser ele quem deve regular, articular e incentivar as iniciativas locais. Quando o poder público é falho, as comunidades podem ter maiores dificuldades de fazer com que a atividade turística se consolide. É, então, de suma importância que os gestores públicos se sensibilizem e articulem a atividade.

\section{Para entender as práticas do destino: metodologia da pesquisa}

A Secretaria de Estado do Turismo do Rio Grande do Sul (Setur/RS), em 2007, através da Lei no 12.845, instituiu a Política Estadual de Fomento ao Turismo Rural. Além disto, instaurou, através de um Termo de Cooperação, o Grupo Gestor de Turismo Rural, que busca realizar ações e programas direcionados ao processo de ordenamento e fortalecimento do Turismo Rural.

A partir destas iniciativas, iniciou um processo de ordenamento e incentivo para o turismo rural nas diversas regiões turísticas do Estado. O Rio Grande do Sul, hoje, está subdividido em 11 regiões turísticas: Pampa Gaúcho, Grande Porto Alegre, Vales, Serra, Hidrominerais, Costa Doce, Rota das Terras, Central, Missões, Yucumã e Litoral Norte. Cada região possui diferentes características de ordenamento, atração e promoção turística, bem como diferentes demandas.

O turismo no Litoral Norte do Rio Grande do Sul, por ser uma região banhada pelo Oceano Atlântico, concentra a demanda de visitantes nos meses de verão ou em feriados, em função da oferta de sol e mar. Neste sentido, o turismo rural desponta como uma tendência que sugere a diversificação dos interesses da demanda não mais concentrada apenas no produto sol e praia, típicos de regiões litorâneas.

Assim, a prática de turismo rural nestas regiões que trabalham com a sazonali- 
Pugen, B.; Aguiar, M.D.S.; Oliveira, V.L.B.

dade pode diversificar a oferta e atrair uma demanda mais específica e constante.

Em razão disto é importante uma reflexão sobre a atividade de turismo rural na região, percebendo a relação entre cultura, economia e natureza e refletindo sobre a sustentabilidade neste meio.

Este estudo teve, então, como objeto de pesquisa o roteiro Vale do Paraíso, no distrito de Morro Azul, em Três Cachoeiras, Litoral Norte Gaúcho e buscou entender se este roteiro de turismo rural insere-se no contexto da sustentabilidade (cultural, econômica e ambiental).

Os objetivos do trabalho foram: identificar e descrever as propriedades integrantes do roteiro Vale do Paraíso; perceber as possibilidades de manutenção da cultura local; identificar o retorno econômico para as propriedades integrantes do roteiro e analisar o nível de preservação ambiental destes empreendimentos.

A presente pesquisa foi do tipo exploratória, de natureza qualitativa. Para Schlüter (2003), a pesquisa exploratória trata de rever documentações atualizadas sobre determinado tema ou analisar pessoas que tiveram experiências com 0 problema a ser estudado. Como instrumentos de pesquisa foram utilizadas entrevistas abertas e estruturadas e observações in loco.

As entrevistas continham questões pertinentes a constituição inicial do roteiro, a atividade principal dos agricultores e perguntas que esclarecessem sobre os aspectos culturais, econômicos e ambientais de cada propriedade. As observações foram feitas para conhecer as propriedades, as práticas rurais e a operacionalização do roteiro.

O roteiro é constituído por 7 (sete) propriedades, que são mantidas por grupos familiares que trabalham diretamente na agricultura. Nesta pesquisa, foram entrevistados os 7 (sete) agricultores que correspondem a cada um dos grupos familiares que compõe as propriedades. Além destes agricultores, foram realizadas 2 (duas) entrevistas com representantes do poder público local (membros da Secretaria de Educação do Município, secretaria que responde pelo Turismo em Três Cachoeiras). Foram realizadas, então, um total de 9 (nove) entrevistas.

As observações, num total de 4 (quatro), puderam aproximar os pesquisadores à realidade local e esclarecer sobre as questões da pesquisa.

A pesquisa foi realizada de março a dezembro de 2011.

\section{Vale do Paraíso: um roteiro sustentável?}

O roteiro Vale do Paraíso foi uma iniciativa dos moradores da localidade que se sentiram motivados a promover a cultura da região. Segundo relatos de uma das integrantes do roteiro (Entrevistado 1) as belezas naturais da localidade, aliadas a colonização italiana, à história dos tropeiros que partiam da região em direção à região serrana e às atividades relacionadas a agricultura motivaram um grupo de moradores a 
buscar auxílio técnico para trabalhar com turismo rural.

As primeiras reuniões dos agricultores interessados em participar do processo deram-se no Clube Vera Cruz, com sede no distrito de Morro Azul (Figura 1). Segundo relatos nas entrevistas alguns integrantes deste Clube, que anualmente organizava uma festa na localidade, vislumbraram a possibilidade de desenvolver a localidade culturalmente, a partir do turismo. Neste momento, conversaram com agricultores que possuíam algum atrativo natural ou cultural em suas propriedades e que teriam interesse em participar de um projeto de turismo. A partir de então, decidiu-se buscar apoio técnico na faculdade de Turismo da Universidade Luterana do Brasil (ULBRA), Campus Torres, juntamente com a Emater (Ascar) e o Sindicato Rural (conforme ata no 01, de 2002). A partir de então algumas propriedades engajaram-se no projeto de desenvolvimento de turismo rural e passaram a organizar-se para receber visitantes.

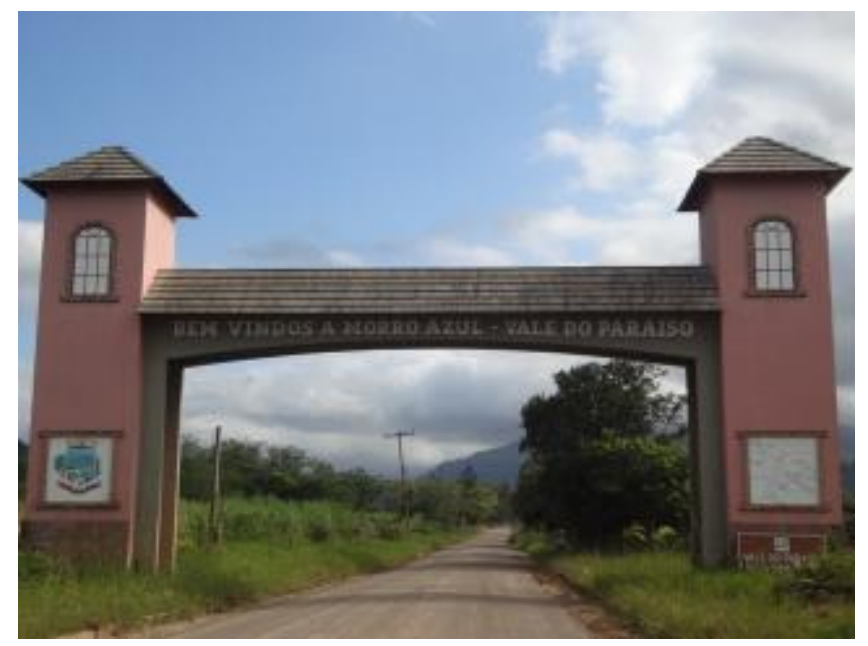

Figura 1: Pórtico do Distrito de Morro Azul. Foto: autores.

Figure 1: Portico of the District Morro Azul. Photo: by authors.

Através das entrevistas e das observações, constatou-se que o roteiro se enquadra no segmento de Turismo Rural, pois os empreendedores mantêm as atividades do campo como receita principal. Alguns, inclusive, citaram que suas atividades agrícolas aumentaram após o incremento do turismo, já que as propriedades integrantes do roteiro demandam de um maior numero de insumos.

Como renda principal, cultivam cana-de-açúcar e bananas. Além destes cultivos, constatou-se que plantam hortifrutigranjeiros, vendendo o excedente para vizinhos e para a cidade. Além disto, há produção agropecuária em pequena escala, que provê carne e leite tanto para autoconsumo quanto para elaboração de pratos servidos aos turistas.

O roteiro (Figura 2) inclui visita a um engenho de cachaça, moinho d'água, artesanato regional, passeios a cavalo, culinária local e trilhas na mata nativa da região. 


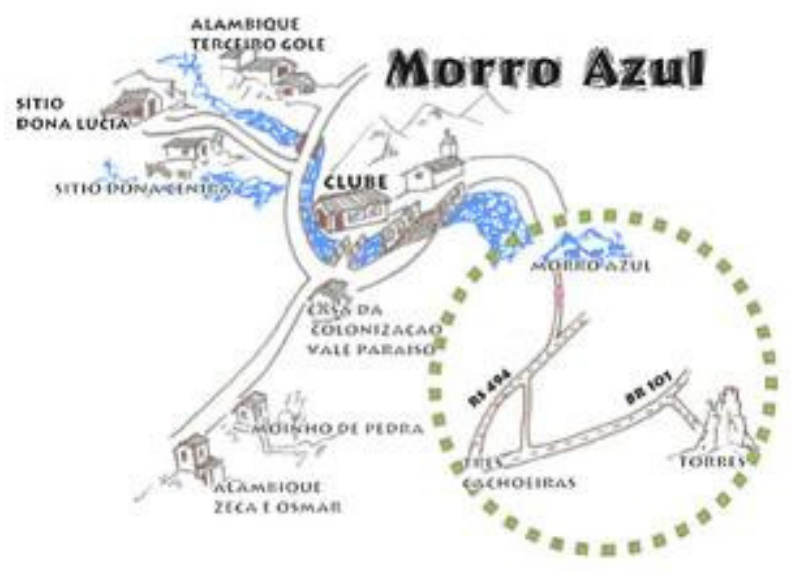

Figura 2: Mapa do roteiro. Fonte: Site da Pousada Casa da Tia Laura.

Figure 2: Map of the tour. Source: Website of Pousada Casa da Tia Laura.

O roteiro inicia no Museu Casa da Colonização (Figura 3), onde a cultura local e parte da história do lugar podem ser apreciadas. A sede do museu foi comprada pelo Clube Vera Cruz em parceria (e com contribuições financeiras) dos agricultores que integram o roteiro. Para montagem do acervo, o grupo realizou uma campanha nas escolas do município para que utensílios pessoais fossem doados. Assim, o museu foi constituído por peças que foram doadas por moradores da localidade e apresenta ao visitante ferramentas, utensílios e vestes dos colonizadores da região. Também possui utensílios que representam a lida do agricultor, desde períodos da colonização italiana na região.

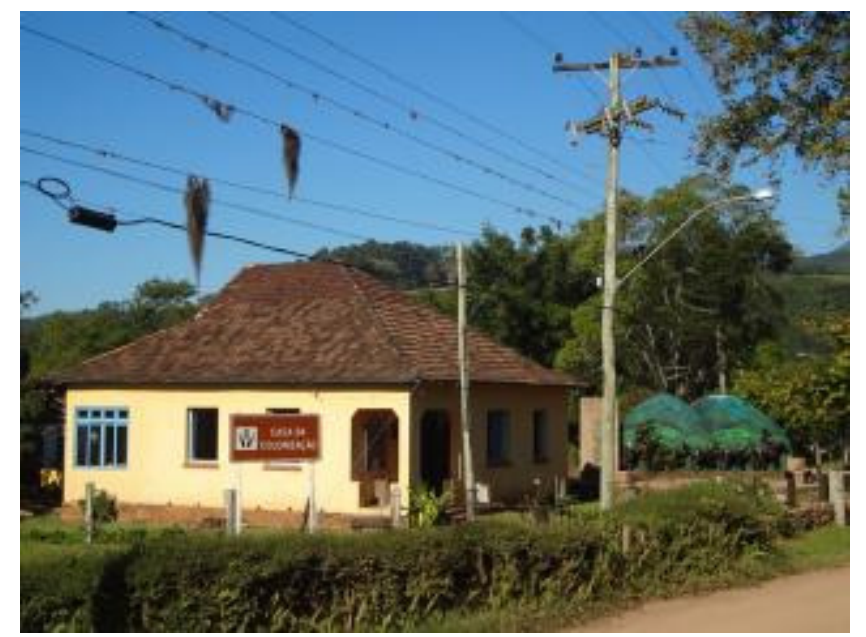

Figura 3: Museu Casa da Colonização. Foto: autores.

Figure 2: Museum Casa da Colonização. Photo: by authors.

Após visitar o Museu, visita-se a propriedade "Pousada Casa da Tia Laura" (Figura 4). Resultado de uma adaptação de uma moradia construída em 1904, a 
propriedade mantém suas características originais em estilo colonial e recebe visitantes para pernoite. A família proprietária da Pousada trabalha com agricultura e participa do roteiro recebendo hóspedes ou servindo almoço aos visitantes, sob agendamento. Destaca-se que todos os produtos servidos no almoço são produzidos na localidade.

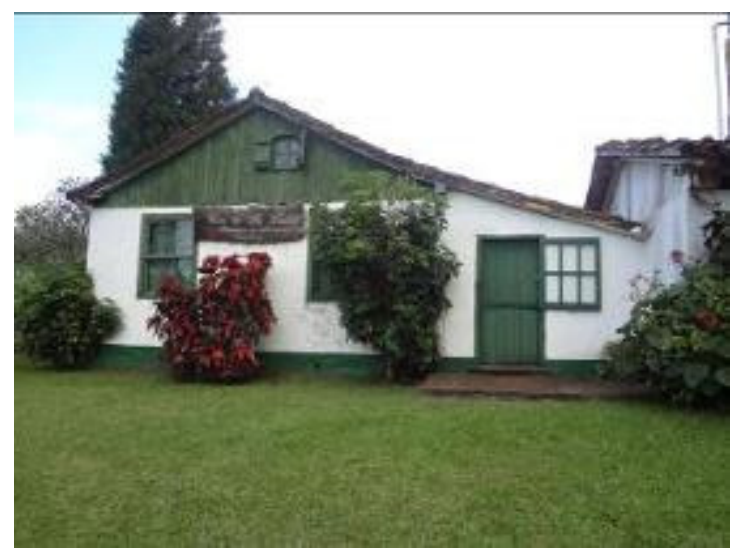

Figura 4: Pousada Casa da Tia Laura. Foto: autores.

Figure 4: Casa da Tia Laura inn. Photo: by authors.

Além da Pousada Casa da Tia Laura, mais duas propriedades oferecem refeições aos visitantes (as refeições são: café rural e almoço): o Sítio Dona Lúcia (Figura 5) e o Sítio Dona Cenira. Os ambientes, antes somente residenciais, foram adaptados para receber visitantes com agendamento prévio, assim como todos os outros empreendimentos. Nestas propriedades o visitante pode, além de realizar refeições, adquirir produtos coloniais feitos na propriedade (exemplo disto é a rapadura feita no Sítio Dona Lúcia, onde tanto o amendoim quanto a cana para feitio de açúcar mascavo utilizados na rapadura são plantados e processados na propriedade). Nestes locais, além da gastronomia, outros atrativos chamam a atenção: cascatas, plantas nativas e trilhas na Mata Atlântica.

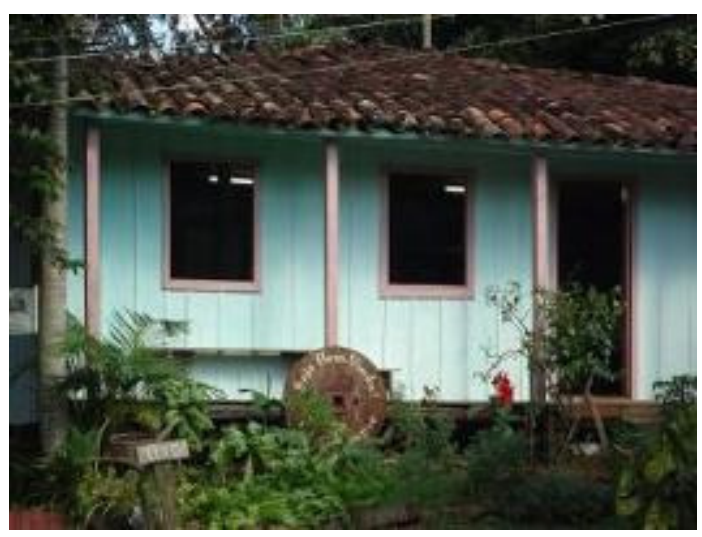

Figura 5: Sítio Dona Lúcia. Foto: autores. Figure 5: farm Dona Lúcia. Photo: by authors.

Outro produto integrante do roteiro é o Moinho de Pedra. Lá se pode conhecer, além da paisagem, parte da história local, contextualizada na história regional. Existe um 
Pugen, B.; Aguiar, M.D.S.; Oliveira, V.L.B.

moinho para moagem da farinha de mandioca em funcionamento, que pode ser visto pelo visitante.

Ainda, no roteiro, existe o Alambique Terceiro Gole (Figura 6), de onde se chega a uma cascata em meio à Mata Atlântica. Esta propriedade trabalha exclusivamente com a cana-de-açúcar e elabora cachaças que comercializa tanto no roteiro quanto para compradores específicos de municípios vizinhos. Importa destacar, segundo relato do agricultor proprietário do alambique, que a inserção do turismo como atividade pluriativa possibilitou que ele viajasse até Minas Gerais, para entender novos e diferentes processos de elaboração de cachaças.

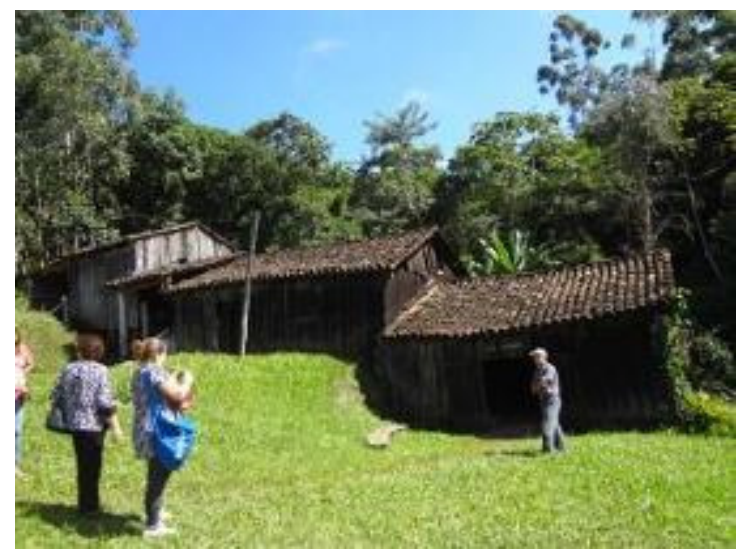

Figura 6: Alambique Terceiro Gole. Foto: autores.

Figure 6: Alembic Terceiro Gola. Photo: by authors.

Também faz parte do roteiro a Casa do Filó (Figura 7). Este espaço foi a primeira escola da localidade e possui 125 anos. O Filó é um hábito trazido pelos imigrantes italianos que, agricultores sem muitos recursos, reuniam-se para trocarem sementes, alimentos e conforto por estarem distantes de sua terra natal. As mulheres confeccionavam artesanato, todos comiam e bebiam dos pratos trazidos pelos agricultores participantes, cantavam e rezavam. Este hábito é resgatado na Casa do Filó, que realiza festejos deste tipo para participação dos turistas.

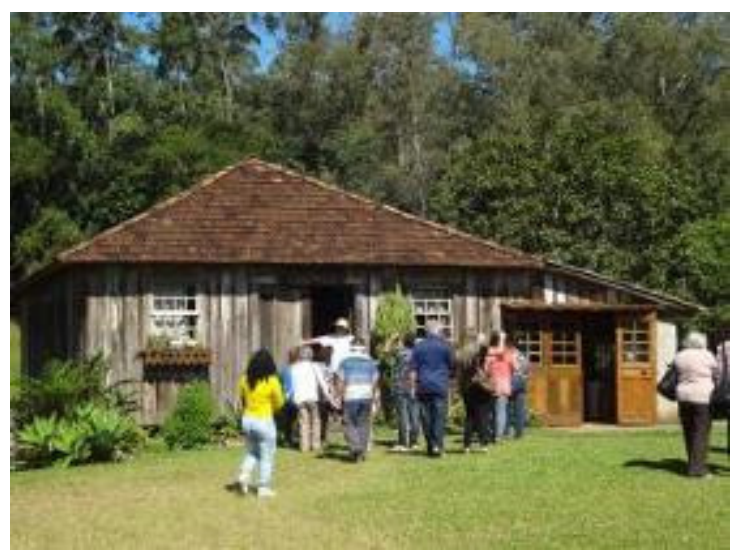

Figura 7: Casa do Filó. Foto: autores.

Figure 7: House of Filo. Photo: by authors 
Em relação a sustentabilidade, no âmbito cultural, ao se analisar interferências na cultura local ou a incorporação de novos hábitos, percebeu-se que não houveram interferências negativas na cultura local. Os entrevistados destacam como únicas interferências o advento da internet e da televisão por assinatura, mas que estes são instrumentos utilizados para uma melhor comercialização e/ou atendimento aos visitantes.

Neste mesmo aspecto pode-se destacar a atividade do Filó. Embora este hábito não aconteça mais da forma como acontecia na comunidade, é interessante perceber esta iniciativa como um resgate cultural transformado em um atrativo turístico. Por isto, nesta análise, não se entrará na discussão de esta ser ou não uma atividade espetacularizada (DEBORD, 1997; HALL, 1999).

As entrevistas apontam que o grupo tem clareza sobre a quantidade de pessoas que recebem para realizar o roteiro, destacando que não Ihes interessa o turismo massivo, "pois queremos mais qualidade do que quantidade" (Entrevistado 2).

Em relação aos aspectos ambientais, quanto à preservação natural, no tocante à paisagem, nota-se que o ambiente é preservado. Poucas interferências se percebem no meio, como o embelezamento do entorno e sinalização externa, que não interferiram significativamente no espaço e não geraram impactos ambientais significativos.

A seleção de resíduos é realizada em todas as propriedades, sendo que os orgânicos são reaproveitados nas propriedades através da compostagem, utilizado como adubo ou como alimento para os animais. Já os resíduos sólidos são recolhidos pela Prefeitura Municipal, porém os residentes desconhecem o destino que é dado aos considerados recicláveis.

Em se tratando dos aspectos econômicos, todos os entrevistados afirmaram que não poderiam e não querem viver apenas da renda gerada pelo turismo. Destacam que a atividade agregou valores à renda familiar e que hoje uma atividade depende da outra (esta afirmação foi feita por todos os entrevistados). Justificam que a atração de turistas se dá em função do território, que tem como atividade principal a agricultura. De outra forma analisam que a agricultura foi incrementada pelo turismo, tornando as duas atividades interdependentes.

Em relação aos aspectos econômicos cabe aqui ressaltar a insatisfação de um entrevistado com o hábito desenvolvido no local de presentear o(s) guia(s), o(s) motorista(s) e o(s) representante(s) das agências que acompanham grupos de visitantes, afirmando que com esta prática muitas vezes o lucro diminui consideravelmente.

Uma outra observação interessante é relacionada aos grupos recebidos por uma instituição comerciária que trabalha com turismo social. Esta entidade realiza visitas no roteiro Vale do Paraíso principalmente no verão, ofertando este roteiro como uma alternativa aos veranistas que estão hospedados em Torres. A duração das visitas é curta (geralmente uma tarde) e os grupos almoçam em locais diversos ao roteiro, o que empobrece a visitação, pois acelera a visita, não dando tempo para que seja realmente aproveitado pelo turista e deixando os receptores frustrados.

Os valores cobrados aos visitantes (tanto individuais quanto grupos) são questio- 
náveis, pois são preços muito acessíveis. Neste aspecto, percebeu-se um conflito entre os integrantes do roteiro, já que alguns entendem que os valores cobrados são justos, outros relatam que não. Mesmo com este impasse, o grupo segue comercializando aos preços estabelecidos para esta instituição, já que "ganham na quantidade" (Entrevistado 4).

As entrevistas apontam para um pequeno aumento no número de empregos locais. Nenhuma propriedade excedeu a contratação de 1 (um) funcionário fixo e mais alguns (poucos) diaristas em dias de recepção de turistas.

Em relação ao poder público, existe uma insatisfação geral quanto a sua atuação no turismo rural da localidade. Neste sentido, destaca-se que os pesquisadores não conseguiram conversar pessoalmente com representantes do setor público, uma vez que os horários para entrevistas não coincidiam com as disponibilidades da Prefeitura. As duas entrevistas realizadas foram feitas via telefone.

O município de Três Cachoeiras não possui um órgão responsável pelo turismo (secretaria de turismo ou departamento de turismo). Há uma funcionária ligada à Secretaria Municipal de Educação que responde pelo turismo do município. Em uma das tentativas esta funcionária afirmou que a Prefeitura não tem envolvimento com o roteiro, já que o roteiro é uma iniciativa da comunidade local e que os contatos deveriam ser feitos com os representantes dos roteiros.

Alguns empreendedores relataram que já solicitaram melhorias de infraestrutura para a Prefeitura (acesso, sinalização), mas suas reivindicações não foram atendidas. Nota-se aqui uma lacuna nas relações políticas locais, já que os moradores nem sempre conseguem fazer chegar até o governo municipal suas reivindicações.

Pode-se avaliar, neste sentido, que o roteiro é fruto do trabalho de pessoas que estão envolvidas com o lugar e que fazem parte da história do município (a maioria é descendente dos primeiros moradores). Tem-se esta iniciativa endógena com algo de grande valia para o desenvolvimento do setor, mas percebe-se que se o poder público tivesse um papel mais ativo o roteiro poderia estar melhor desenvolvido.

Outro aspecto que poderia contribuir com o roteiro é a comercialização por operadoras turísticas e agências de viagens diversas, pois, até então, o roteiro é comercializado quase que exclusivamente pela instituição do setor comerciário que trabalha com turismo social. Algumas agências da região comercializam o roteiro, de forma incipiente, e alguns visitantes individuais visitam a localidade, principalmente quando esta realiza algum evento. Aqui, destaca-se a importância da realização de eventos para atrair um público diversificado.

Por fim, analisa-se este roteiro como de grande potencial para o fomento do turismo na região. Destaca-se uma iniciativa que é mantida e fomentada por empreendedores locais e apoiada pela comunidade local. Assim, é importante analisar o papel do poder publico no desenvolvimento de uma destinação turística. Com a articulação do governo municipal o roteiro poderia atingir níveis mais interessantes de desenvolvimento. 


\section{Considerações finais}

O roteiro Vale do Paraíso pode ser considerado um roteiro turístico de iniciativa tipicamente endógena. É desenvolvido a partir do interesse dos próprios residentes, que viram no turismo a oportunidade de preservar seu espaço, mostrar a cultura local e aumentar a renda (especialmente da mulher), pois a agricultura, antes atividade única, passa a coexistir com o turismo.

Importa destacar a participação das mulheres na formatação e operacionalização do roteiro e, ainda, participando de cursos de artesanato, associativismo e outras atividades de grupo que estimulam a prática do turismo como atividade associativa.

As questões culturais, ambientais e econômicas apontam para uma prática que vai ao encontro dos conceitos da sustentabilidade, embora alguns fatores mereçam atenção.

O primeiro é em relação a precificação do roteiro. Sabe-se que para que uma atividade tenha retorno econômico e gere renda é importante que se cobre um preço justo. Nota-se que os valores pagos pelos grupos que visitam o roteiro ou que visitam alguma propriedade são valores quase que simbólicos. Os preços são acessíveis demais para cobrir custos e ainda gerar renda. As diárias na Pousada integrante do roteiro, os "cafés" servidos e os ingressos (quando cobrados) custam pouco para quem paga e também contribuem pouco para quem cobra. Seria importante uma revisão nos valores cobrados pelas propriedades integrantes do Vale do Paraíso.

Em relação às questões ambientais, seria importante que a Prefeitura Municipal (responsável pela coleta dos resíduos das propriedades) informasse a população sobre 0 destino destes resíduos, se há alguma cooperativa de catadores beneficiada ou como é feita a destinação. A comunidade local talvez pudesse estar melhor informada sobre isto, reafirmando assim seu papel de cidadão.

Também é importante relatar a inexistência de uma sensibilização ambiental sistematizada nas propriedades que operam o roteiro. Seria interessante se houvesse algumas ações estabelecidas para que o visitante se conscientizasse sobre as questões ambientais, utilizando os locais visitados no roteiro como ferramenta de educação ambiental.

Morro Azul, o distrito onde é realizado o roteiro, possui belezas naturais singulares e uma comunidade comprometida, que desenvolve o roteiro sem o envolvimento públicoprivado tão presente nos debates teóricos. A Prefeitura Municipal tem papel passivo neste contexto, pois apenas se beneficia com a presença de visitantes no município e com a divulgação gratuita que o município de Três Cachoeiras tem a partir de um trabalho desenvolvido pela comunidade. É importante que o poder público municipal se aproprie deste roteiro, contribuindo com ações que são de responsabilidade pública.

Ao finalizar o artigo, é importante falar das limitações da pesquisa. Esta, desenvolvida ao longo de 2011, tornou-se complexa demais para pouco tempo de pesquisa. Tratar da sustentabilidade é um desafio, pois este tema abarca uma gama de questões que sugerem outras abordagens e estudos, muito difíceis de serem tratadas em um único trabalho.

Em função disto o estudo tratou de maneira superficial a questão da sustentabilidade no turismo rural. Seria interessante um aprofundamento deste estudo ou um desdobramento para um estudo mais aplicado. Novas pesquisas podem de debruçar sobre este ro- 
Pugen, B.; Aguiar, M.D.S.; Oliveira, V.L.B.

teiro, estudando as relações entre visitantes e visitados, as relações de conflitos entre setor público e comunidade, as questões econômico-financeiras das propriedades e, ainda, as interferências ambientais geradas a partir da configuração daquele espaço turístico.

\section{Referências bibliográficas}

ALMEIDA, J.A.; FROEHLICH, J.M.; RIEDL, M. (orgs.). Turismo e Desenvolvimento Sustentável. Campinas, SP: Papirus, 2000.

BARRETTO, M. Manual de iniciação ao estudo do turismo. Campinas, SP: Papirus, 2003.

BENI, M.C. Política e planejamento do turismo no Brasil. São Paulo: Aleph, 2006

CAMPANHOLA, C., GRAZIANO DA SILVA, J. O Novo Rural Brasileiro. Jaguariúna, SP: Embrapa Meio Ambiente, 2000.

DEBORD, G. A sociedade do espetáculo. Rio de Janeiro: Contraponto, 1997.

HALL, C.M. Planejamento turístico: políticas, processos e relacionamentos. São Paulo: Contexto, 2001.

HALL, S. A identidade cultural na pós-modernidade. Rio de Janeiro: DP\&A, 1999.

KRIPPENDORF, J. Sociologia do Turismo: para uma compreensao do lazer e das viagens. Sao Paulo: Aleph, 2000.

KUBO, R.R.; SOUZA, C.; Tempo de artesanato: reflexões em torno do devir na etnografia do processo de busca de uma alternativa econômica. In: Atualidades em Etnobiologia e Etnoecologia. KUBO, R.R., BASSI, J.B., SOUZA, C., ALENCAR, N.L., MEDEIROS, P.M., ALBUQUERQUE, U.P. (org.) Recife: NUPEEA, 2006.

MTUR. Ministério do Turismo. Turismo e sustentabilidade: formação de redes e ação municipal para regionalização do turismo. In: BRIZOLLA, T.; LIMA, A.C.G. (orgs). Programa de Qualificação a Distância para o Desenvolvimento do Turismo. Brasilia: o Ministério: Florianópolis: SEaD/UFSC, 2008.

MOLINA, S. Fundamentos del nuevo turismo. México, 2005.

OLIVEIRA, A.U. Modo capitalista de produção e agricultura. São Paulo: Ática, 1986.

OMT. Desenvolvimento de turismo sustentável: manual para organizadores locais, 1998.

RATTNER, H. Liderança para uma sociedade sustentável. São Paulo: Nobel, 1999.

REJOWSKI, M. Turismo no percurso do tempo. São Paulo: Aleph, 2002

RODRIGUES, A.B. Turismo e geografia: Reflexões teóricas e enfoques regionais. São Paulo: Hucitec, 1996.

RUSCHMANN, D. M. O turismo rural e o desenvolvimento sustentável. In: ALMEIDA, J.A.; FROEHLICH, J.M.; RIEDL, M. (Org.). Turismo Rural e o Desenvolvimento Sustentável. Campinas: Papirus, 2000.

SABOURIN E. Que política pública para a agricultura familiar no segundo governo Lula?. Sociedade e Estado, set./dez. 2007. 
SANTOS, M. J. Projetos alternativos de desenvolvimento rural sustentável. Estudos avançados, São Paulo, vol 15, set/dez 2001.

SCHNEIDER, S. Políticas Públicas, pluriatividade e desenvolvimento rural no Brasil. Anais do VII Congreso de la Asociación Latinoamericana de Sociología Rural/ALASRU: Ecuador, 2006.

SWARBROOKE, J. Turismo sustentavel: conceitos e impacto ambiantal. Aleph, 2000.

TOMAZZONI, E. L. Organização de feiras de negócio: um modelo de gestão para feiras de negócio de Caxias do Sul. Caxias do Sul: UCS, 2002. Dissertação (Mestrado em Turismo), Universidade de Caxias do Sul, 2002.

TULIK, O. Turismo Rural. São Paulo: Aleph, 2003.

TURISMO, Secretaria de Estado do. LEI № 12.845. Assembleia Lgislativa: Porto Alegre, 2007.

TURISMO, Secretaria de Estado do. Site da Secretaria. http://www.turismo.rs.gov.br/ portal/index.php?q=destino\&cod=3\&opt=24\&fg=2\&tp=24 Acesso em 12/07/2011.

VEZZANI, M. A. Turismo rural e responsabilidade ambiental e ecológica no espaço rural brasileiro. Caderno Virtual de Turismo, vol. 8, núm.1, 2008.

WWF-BRASIL. Certificação em Turismo: Lições mundiais e recomendações para o Brasil. SALAZAR, S. (Coord.). Brasília: WWF-Brasil, 2001.

Bianca Pugen: Instituto Federal de Educação, Ciência e Tecnologia do Rio Grande do Sul, Osório, RS, Brasil.

Email: bianca.pugen@osorio.ifrs.edu.br

Link para o currículo Lattes: http://lattes.cnpq.br/9588812374487167

Marcos Daniel Schmidt de Aguiar: Instituto Federal de Educação, Ciência e Tecnologia do Rio Grande do Sul, Osório, RS, Brasil.

Email: marcos.aguiar@osorio.ifrs.edu.br

Link para o currículo Lattes: http://lattes.cnpq.br/9133687917403690

Vera Lúcia Boeno de Oliveira: Instituto Federal de Educação, Ciência e Tecnologia do Rio Grande do Sul, Osório, RS, Brasil.

Email: vluciaboeno@gmail.com

Link para o currículo Lattes: http://lattes.cnpq.br/2394406212890079

Data de submissão: 22 de maio de 2012

Data de recebimento de correções: 15 de maio de 2013

Data do aceite: 11 de junho de 2013

Avaliado anonimamente 
Moreira, J.F.R.; Almeida, M.G. O lugar Kalunga como lugar turístico: um olhar sobre o turismo rural no Engenho II em Cavalcante (GO). Revista Brasileira de Ecoturismo, São Paulo, v.6, n.3, ago/out-2013, pp.708-721.

\title{
O lugar Kalunga como lugar turístico: um olhar sobre o turismo rural no Engenho II em Cavalcante (GO)
}

\author{
The Kalunga's place of the tourist place: a glimpse into rural tourism \\ in Engenho II (Cavalcante, GO, Brazil)
}

\section{Jorgeanny de Fátima Rodrigues Moreira, Maria Geralda de Almeida}

\section{RESUMO}

No presente artigo apresentamos algumas reflexões e discussões acerca do desenvolvimento do turismo cultural e rural no Engenho II. Essa comunidade é constituída por remanescentes de quilombolas e localiza-se no município de Cavalcante, nordeste de Goiás. A atividade turística nessa comunidade é uma prática bastante incipiente, mas tem-se configurado como uma alternativa para o complemento de renda e amenização do êxodo rural. Os principais potenciais dessa área são os atrativos naturais e as práticas culturais, em especial suas manifestações festivas. No entanto, cabe investigar se a apropriação do turismo contribui para a preservação desses valores ou representa apenas mais um envolvimento efêmero e fugaz entre turista e lugar turístico. Pesquisas bibliográficas sobre o tema, observação e entrevistas com moradores são aportes teóricos e metodológicos que subsidiam o desenvolvimento da discussão. As possibilidades para o desenvolvimento do turismo na área são grandes, mas os Kalunga enfrentam desafios para a efetivação dessa atividade, conforme foram detalhados nas considerações finais.

PALAVRAS-CHAVE: Kalunga; Quilombolas; Comunidade Local; Turismo Rural.

\section{ABSTRACT}

In this article we presents some discussions about the development of cultural and rural tourism in the Engenho II. This community are remnants of quilombola. Is the located in the Cavalcante, Goias northern, Brazil. The activities of tourism in this community are practices fairly crude, but it has been configured as an alternative to income supplement and mitigate the rural exodus. The main potential of this area are the natural attractions, but as regards cultural practices. However it is worth investigating whether the ownership of tourism contributes to the preservation of those values or involvement is just another ephemeral and fleeting between tourist and tourist place. Research literature on the subject, observation and interviews with residents are theoretical and methodological contributions that support the development of the discussion. The possibilities for the development of tourism in the area is great, but as we'll see, Kalunga face challenges in the realization of this activity, as investments for the implementation of tourism infrastructure, involvement of the entire population and degradation of the attractions.

KEY-WORDS: Kalunga; Quilombolas; Local Community; Rural Tourism. 


\section{Introdução}

A busca pela prática do turismo em comunidades rurais tem se tornado cada vez mais frequente. Essa procura se dá pela valorização do meio natural e bucólico. As paisagens simbólicas presentes no meio rural promovem a idealização dos indivíduos que procuram descanso e contato com a natureza.

A paisagem cultural dessas áreas também intensifica a procura, pois remete ao turista, o olhar sobre as atividades praticadas no campo, como a fabricação de alimentos com frutos e legumes colhidos nas roças e as celebrações religiosas que acontecem no meio rural.

Em decorrência, alguns municípios brasileiros têm se adaptado a atividade turística, ao implantar novos empreendimentos. O atendimento à demanda turística é uma alternativa para as comunidades que vivem da agricultura familiar, já que a modernização no campo e a expansão dos grandes produtores agrícolas impossibilitam a competição do pequeno agricultor no mercado agropecuário.

O turismo é uma oportunidade para a geração de emprego e renda, além de promover a qualidade de vida da população local. No meio rural, essa atividade pode tornar-se uma estratégia para o desenvolvimento, ao explorar economicamente os aspectos culturais e simbólicos.

As potencialidades turísticas podem ser apropriadas, com base comunitária fortalecida pelo associativismo e/ou cooperativismo. Dessa forma, toda a comunidade é beneficiada, por meio da geração de emprego, inclusão social e desenvolvimento, que ocorre na medida em que a população local participe nas tomadas de decisões.

No presente artigo pretendemos discutir o desenvolvimento da atividade turística em uma comunidade rural habitada por descendentes de quilombolas, identificados como Kalunga: o Engenho II. Essa comunidade localiza-se em Cavalcante, Goiás a aproximadamente $400 \mathrm{~km}$ de Brasília. Nela, seus potenciais turísticos como cachoeiras, trilhas e paisagens culturais são explorados principalmente por empreendimentos situados no centro urbano de Cavalcante, como agências de viagens e guias turísticos.

A apropriação do turismo por parte da própria comunidade do Engenho II, ainda é bastante incipiente, tendo como principais atividades: a condução de turistas pela área; casas em que seus moradores vendem almoços, lanches, bebidas e artesanatos; aluguel dos quintais para camping.

Pretende-se com o texto responder as seguintes indagações: Como acontece o envolvimento da população local para o desenvolvimento da atividade turística no Engenho II? Quais cooperações e conflitos que emergem com este envolvimento? O turismo na área rural dos quilombolas permite a valorização e preservação do patrimônio natural e cultural da comunidade? O lugar Kalunga, pautado nos laços simbólicos de pertencimento, se configura em mais um lugar turístico, caracterizado pela relação fugaz e efêmera próprias dessa atividade?

Esse artigo foi dividido em três partes teóricas contendo algumas reflexões acerca do turismo de base comunitária e a análise do desenvolvimento da atividade 
turística no Engenho II. Nessa discussão, apresentaremos alguns dados coletados em campo, com base na observação e entrevistas com alguns moradores no período compreendido entre os meses de julho de 2011 a janeiro de 2012.

\title{
Apontamentos para se pensar o turismo cultural e de base comunitária em áreas rurais
}

A prática do turismo em comunidades rurais é considerada uma estratégia para o desenvolvimento local e o resgate da autoestima do homem do campo, na medida em que ocorre a valorização da identidade cultural incentivada pela presença de moradores do centro urbano. $O$ turismo rural também contribui para estimular a produção, o empreendedorismo e a manutenção das famílias no campo, ao diminuir o fluxo migratório campo-cidade. Além disso, o turismo auxilia na persistência sociocultural das formas tradicionais de produção.

O conceito de Turismo adotado pelo Ministério do Turismo, "fundamenta-se em aspectos que se referem ao território, à base econômica, aos recursos naturais e culturais e à sociedade" (BRASIL, 2009, p.313). O Turismo Rural é conceituado pelo mesmo órgão como "um conjunto de atividades turísticas desenvolvidas no meio rural, comprometidas com a produção agropecuária, agregando valor a produtos e serviços, resgatando e promovendo o patrimônio cultural e natural da comunidade" (BRASIL, 2009, p.19).

Esse tipo de turismo é considerado uma atividade capaz de agregar valor as práticas rurais e gerar renda a população, permitindo que as atividades ligadas a agricultura e pecuária continuem sendo executadas. Moletta (2002) classifica o turismo rural como

\begin{abstract}
uma atividade de lazer que o homem urbano procura junto às propriedades rurais produtivas, buscando resgatar suas origens culturais, 0 contato com a natureza e a valorização da cultura local. Já para o homem do campo, significa um meio para aumentar a sua renda mensal, de forma harmônica, valorizando sua propriedade e o seu estilo de vida (MOLETTA, 2002, p. 9).
\end{abstract}

Nessa perspectiva, o turismo rural, assim como os demais segmentos turísticos, tem o objetivo de proporcionar lazer aos moradores de centros urbanos e gerar renda para o destino turístico. Enquanto que para o homem do campo, a prática do turismo permite a valorização dos símbolos e costumes da vida no meio rural. Campanhola e Silva defendem que essa segmentação:

Ao mesmo tempo em que depende da gestão do espaço local e rural para o seu sucesso, contribui para a proteção do meio ambiente e para a conservação do patrimônio natural, histórico e cultural do meio rural. Representa, portanto, um instrumento de estímulo à gestão e ao uso sustentável do espaço local, que devem beneficiar prioritariamente a população local direta e indiretamente envolvida com as atividades turísticas (CAMPANHOLA; SILVA, 2000, p.152). 
Os autores defendem o turismo rural como propulsor da valorização dos aspectos culturais e tradicionais no campo, ao mesmo tempo em que beneficia o pequeno proprietário ao gerar renda e o uso equilibrado do espaço local. Além disso, a população é a principal gestora dessa atividade e quem define o perfil do turista que deseja na propriedade. Em decorrência, contribui para o melhor uso do espaço rural, evitando a degradação dos atrativos utilizados.

A importância em se criar alternativas para a complementação da renda no meio rural, deve-se as transformações nas relações de produção no campo, que tem dificultado a relação do campesino ao modo de vida tradicional. A modernização na agricultura, como o emprego de técnicas mais sofisticadas e instrumentos que precisam ser adquiridos a preços mais elevados, inviabiliza as técnicas empregadas nas pequenas propriedades rurais baseadas na agricultura familiar, uma vez que a "produção familiar se caracteriza pelo trabalho familiar na exploração agropecuária e pela propriedade dos meios de produção" (MARAFON; RIBEIRO, 2006, p. 112).

A concentração de renda na região Sul de Goiás, em virtude de processos de ocupação, povoamento, modernização e mecanização no campo de forma mais intensa, conferiu as regiões norte e nordeste de Goiás, um processo lento na dinâmica econômica. Isso se deve aos "grandes problemas próprios de nossa formação periférica e das ações direcionadas para o crescimento de determinadas regiões do estado" (ARRAIS, 2004, p.59).

Para o autor, a pobreza da região norte/nordeste é consequência da "ação dos grupos econômicos aliados ao Estado, que reforçaram a acumulação do capital" nas regiões Sul e Sudeste goiano. Em decorrência, fenômenos como o êxodo rural, principalmente dos mais jovens em busca de melhores condições de vida, são comuns nas demais regiões de Goiás.

O turismo pode ser uma alternativa para abrandar essas desigualdades, contribuindo para a complementação da renda familiar, (re) significando os valores e costumes das comunidades e fortalecendo os laços desses indivíduos com o lugar.

No entanto, não há políticas públicas ligadas ao interesse de desenvolvimento do turismo no meio rural, no norte e nordeste do estado de Goiás. A comunidade Engenho II em Cavalcante, Goiás (Figura 1) é liderada por um morador que representa a comunidade junto ao município, ao estado e ao mercado privado. Esse representante organiza e mobiliza os moradores, que mostram interesse na atividade turística, no intuito de fortalecer o associativismo.

Sob a liderança desse representante - presidente e/ou líder local responsável por todas as atividades do lugar -, os Kalunga do Engenho II desenvolvem, de maneira bastante incipiente, o turismo de base comunitária. A comunidade, a partir de uma decisão interna, trabalha junto à associação. Nas palavras de Irving:

[...] o turismo de base comunitária resulta de uma demanda direta dos grupos sociais que residem no lugar turístico, e que mantém com este território uma relação cotidiana de dependência e sobrevivência material e simbólica. Assim, não é possível imaginar uma iniciativa de turismo de base comunitária resultante de uma decisão externa, de uma intervenção exógena à realidade e aos modos de vida locais (IRVING, 2009, p.112). 

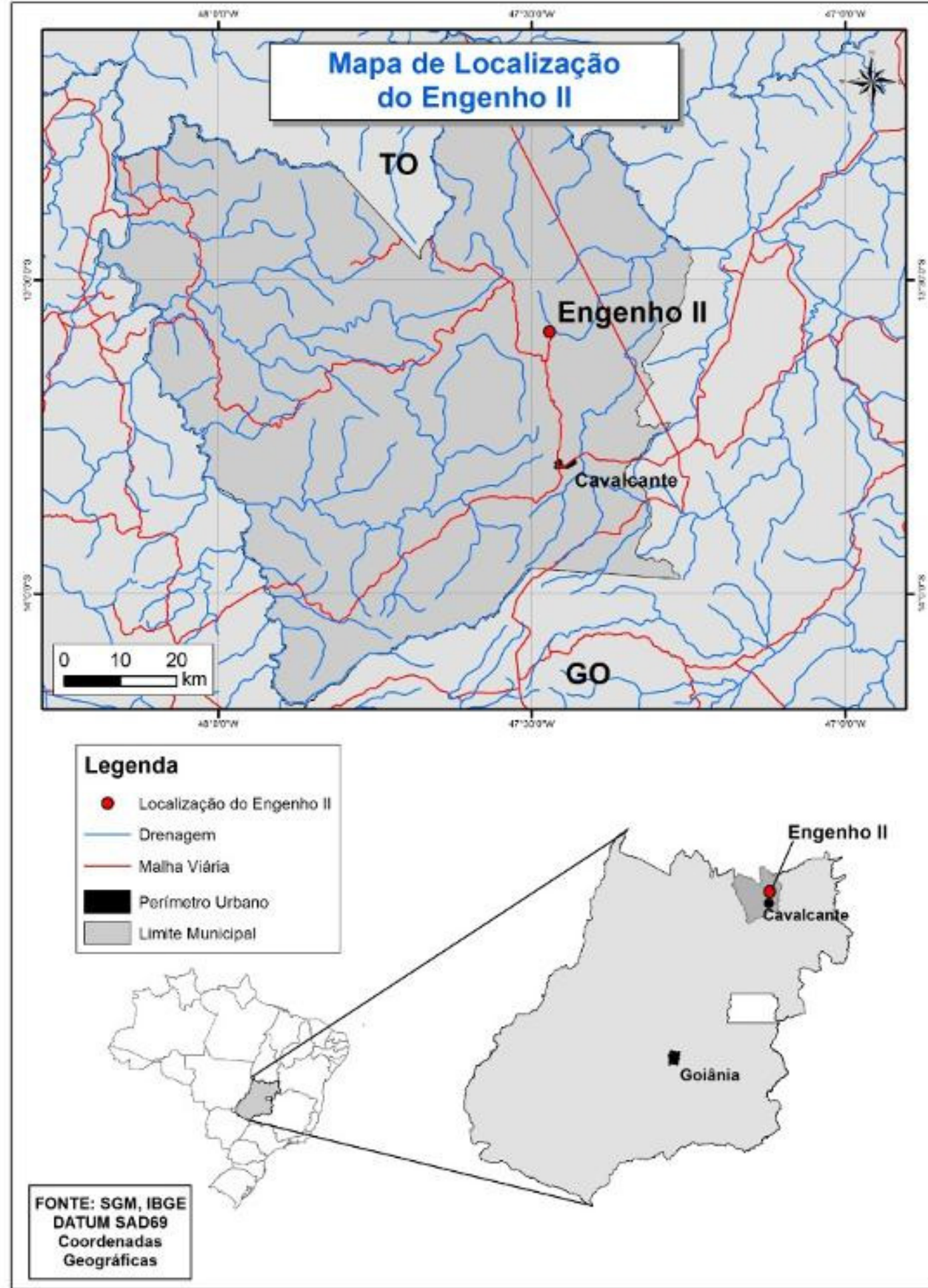

Figura 1: Mapa de Localização. Organização: Jorgeanny de Fátima R. Moreira; Elaboração: Alexandre Henrique Cardoso. Setembro de 2012.

Figure 1: Location Map. Organization: Jorgeanny Fatima R. Moreira; Prepared by: Alexandre Cardoso. September 2012. 
No Engenho II, as iniciativas dos trabalhos ligados ao turismo partem dos próprios moradores. Esses indivíduos conhecem as necessidades da comunidade, bem como suas potencialidades, e por meio do associativismo organizam e implantam as atividades que podem ser desenvolvidas pela população local.

O associativismo tem como base o trabalho em cooperação e a participação de um grupo social com interesses em comum. Por meio da organização social, visando à melhoria da qualidade de vida e o desenvolvimento local, a comunidade trabalha no sentido de desenvolver estratégias para a produção solidária.

Essa alternativa pode promover a inclusão social, por meio do processo de desenvolvimento da atividade turística. Além de fortalecer as relações entre os moradores, esse tipo de turismo valoriza a cultura local, na medida em que incentiva a relação de pertencimento ao lugar em que se vive.

A Associação dos Condutores de Turismo Kalunga no Engenho II, recebe jovens de 18 a 35 anos de idade, de ambos os sexos, interessados em trabalhar como condutores de turismo na área do quilombo. Essa associação constitui-se de um grupo de 70 pessoas sob a liderança do presidente e/ou líder local. Esse morador tem a responsabilidade de coordenar as atividades do grupo, organizando roteiros e escalas de guiamento para os envolvidos, de forma que todos tenham trabalho ao longo da semana.

As reuniões acontecem na casa desse líder, bem como as saídas com os turistas para o guiamento pelas trilhas e cachoeiras da comunidade. Cada guia cobra cinquenta reais para acompanhar um grupo com até seis turistas. Do valor cobrado, dez por cento é destinado à Associação, esse dinheiro é revertido em equipamentos e serviços para a comunidade.

Há famílias que não pretendem se dedicar ao mercado turístico. Alguns moradores não acreditam nessa atividade como uma forma de melhoria na qualidade de vida. Em muitos casos, apenas um membro da família é condutor. Esses trabalhadores são jovens que veem no turismo uma forma de não emigrar para os centros urbanos. Um dos guias Kalunga conta que residiu durante seis meses em Brasília, mas preferiu voltar ao Engenho II, pois não se adaptou a rotina da capital federal.

Com o associativismo, a comunidade é quem participa da tomada de decisões e pode influenciar o desenvolvimento comercial ao administrar os ganhos ligados ao turismo. Além disso, o trabalho em conjunto pode aumentar a tolerância dos moradores em relação ao turismo, já que este pode ocasionar a intensificação do uso do espaço por indivíduos que não são daquele lugar.

O envolvimento da comunidade no processo de desenvolvimento da prática turística, também pode reduzir os impactos negativos do turismo (SWARBROOKE, 2000). A degradação dos atrativos turísticos e a mudança na rotina dos moradores podem ser controladas, a partir da participação e conscientização de toda a comunidade local, no sentido de se pensar estratégias para promover o turismo de forma responsável e solidária. 
A fim de evitar conflitos entre moradores e turistas no uso do espaço, Irving (2009) propõe pensar o lugar como ponto focal da transformação social, ou seja, é necessário que o morador veja as singularidades e particularidades do seu lugar como o principal atrativo turístico, e em consequência, o fator essencial para o desenvolvimento da qualidade de vida da população local. Segundo a autora

o turismo, em qualquer de suas formas de expressão e intervenção, interfere na dinâmica socioambiental de qualquer destino, o turismo de base comunitária só poderá ser desenvolvido se os protagonistas deste destino forem sujeitos e não objetos do processo (IRVING, 2009, p.111).

Portanto, no turismo de base comunitária é a população quem toma as decisões, é ela quem decide o perfil do turista que deseja receber e o que deve ser explorado enquanto atrativo. A atividade turística pode contribuir para a intensificação dos laços sociais, entre os próprios moradores e destes com os turistas. Para a efetivação do turismo de base comunitária é necessário à motivação e o envolvimento da comunidade local no seu desenvolvimento.

\section{Potencialidades para o desenvolvimento do turismo rural no Engenho II}

O meio rural adquiriu o valor de lugar turístico por responder a uma demanda contínua de turistas interessados em suas cachoeiras, trilhas, serras e práticas culturais. Almeida (2007) explica que o desejo por conhecer novos lugares está no desejo de desterritorializar-se a partir da imagem criada pelo turismo. Nas palavras da autora

[...] a propaganda que the dá o corpo, faz com que o homem procure cada vez mais a fantasia, o exotismo, a nostalgia, o novo, o diferente, sendo a natureza o que mais se presta a atender os apelos do imaginário do homem citadino, por excelência, o turista (Almeida, 2007, p.102-103).

A busca do citadino por áreas "naturais" revela uma apropriação sobre o ambiente e se mostra como um mecanismo que transforma intensamente o espaço. $O$ turismo transforma os aspectos naturais e sociais de determinada sociedade em um produto para o mercado do lazer. O turismo rural é um exemplo da efetivação da relação, ente o natural e o cultural.

No Engenho II, a motivação pela busca do turismo se dá pela extensa área natural e pelas práticas culturais da população local. No espaço habitado pelos Kalunga predomina os vãos, serras e morros, depressões e vales estreitos, com a presença de rios e uma vegetação típica do cerrado "stricto sensu", pois "apresenta maior densidade de árvores em relação às formas arbustivas e herbáceas, [...] com altura média variando entre 3 e 8 metros" (OLIVEIRA, 2005, 184) (Figura 2). 


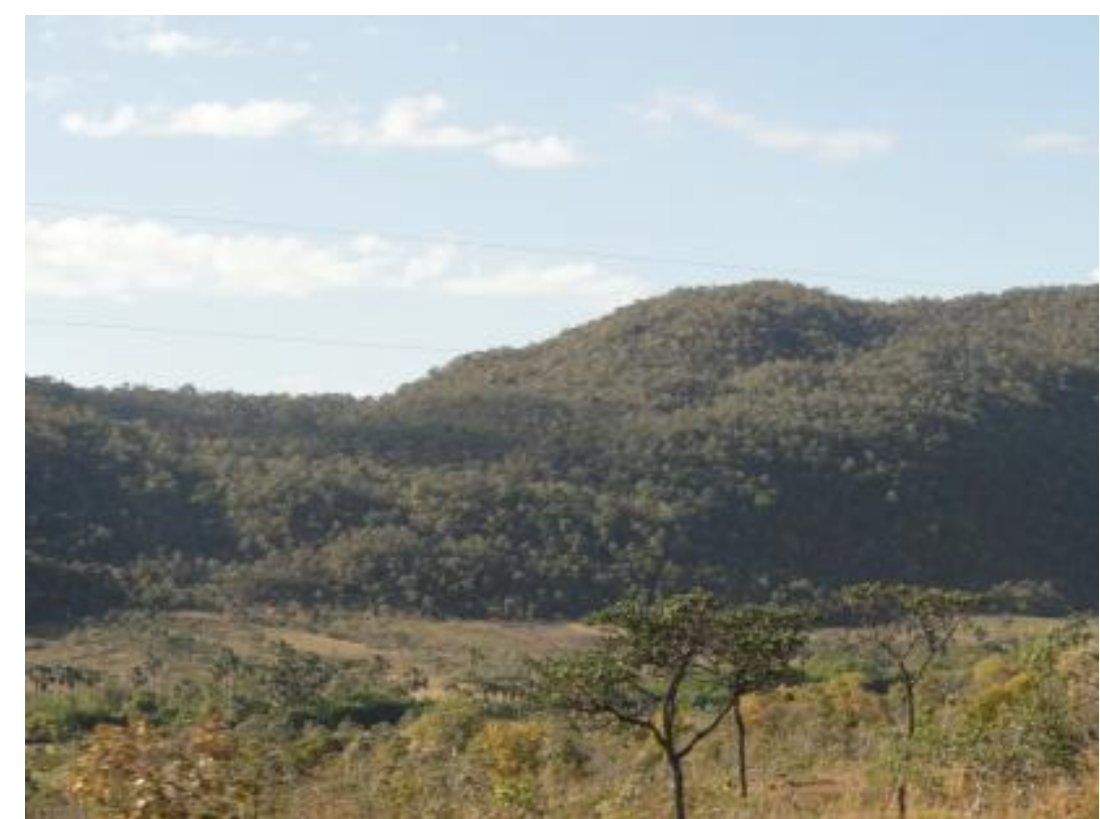

Figura 2: Vegetação Serra Geral, Cavalcante (GO) - Vista Engenho II. Foto: Jorgeanny de Fátima R. Moreira, Julho de 2011.

Figure 2: Vegetation Serra Geral, Cavalcante (GO) - View of Engenho II. Photo: Jorgeanny Fatima R. Moreira, July 2011.

Esse espaço é conhecido como "Vãos da Serra Geral, parte ocupado pelo vale do Rio Paranã e seus afluentes, às bordas da Chapada dos Veadeiros na qual se encontra o Parque Nacional da Chapada dos Veadeiros" (ALMEIDA, 2003, p. 3). Além dos aspectos naturais, as manifestações culturais e religiosas dos Kalunga evidenciam a construção da identidade com o lugar, a partir da (re) significação das tradições estabelecidas na organização do trabalho, política e sociedade.

Esses aspectos se configuram como um atrativo turístico para moradores de cidades como Cavalcante, Brasília e Goiânia. Tanto os atrativos culturais, quanto os naturais, como as cachoeiras Santa Bárbara e Capivara, localizadas no Engenho II, são os mais procurados na Serra Geral. Os turistas que buscam por esses lugares são tentados a participar das festas, uma vez que essas manifestações despertam a curiosidade dos visitantes, deslumbrados com o mito de que essa sociedade vivia sob o isolamento até meados da década de 1970.

Alguns turistas, presentes no mês de julho de 2012, afirmavam estar ansiosos para conhecer a comunidade, esperando encontrar um grupo social com os mesmos hábitos, costumes e alimentos do período colonial. Sr. S. B. M. (Advogado, morador de Brasília) argumenta que esperava ver algumas danças de origem africana com traços do Candomblé ou Umbanda. Estava surpreso em encontrar "uma comunidade rural de fé católica". O advogado e sua família ficaram fascinados com o modo de vida simples do campo e com os alimentos orgânicos vendidos em algumas casas Kalunga (Figura 3). 


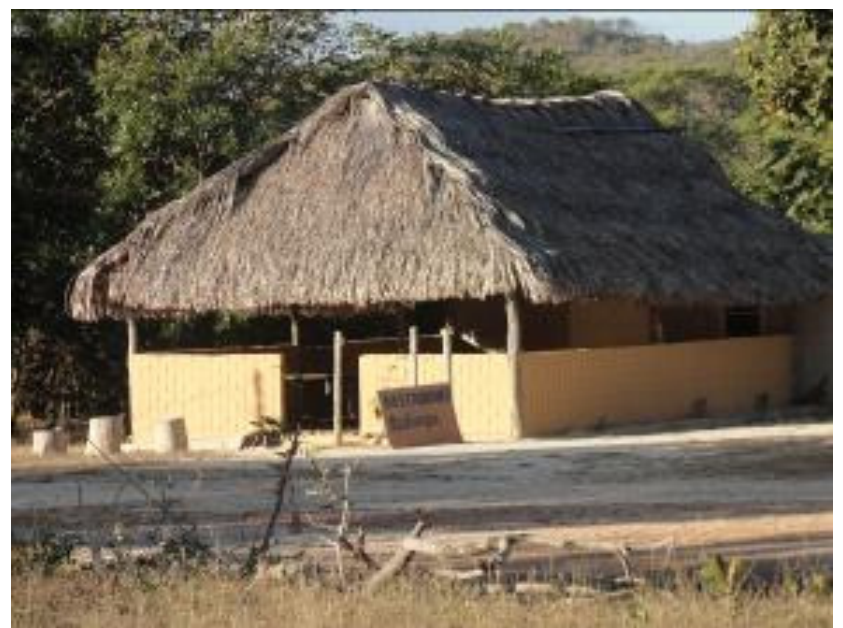

Figura 3: Restaurante Kalunga - Engenho II. Foto: Jorgeanny de Fátima R. Moreira, Julho de 2011.

Figure 3: Restaurant Kaluga - Engenho II. Photo: Jorgeanny Fatima R. Moreira, July 2011.

A relação com o espaço de vivência e cotidiano dos moradores pode ser apreendido pelos turistas, quando acompanhados pelos condutores de turismo Kalunga e moradores do Engenho II. Nesses roteiros os condutores locais apresentam a área quilombola e falam sobre o modo de vida e as lendas que envolvem o surgimento do quilombo.

Alguns turistas participam das festas de encerramento das folias de Santos Reis e de Santo Antônio, nos meses de Janeiro e Julho respectivamente. É nesse momento que acontece, de forma mais intensa o contato entre visitante e visitado, por meio do jantar comunitário (organizado pela comunidade local) e o forró. Os signos durante a festa são espontâneos, é o momento no qual se intensifica o convívio social da comunidade, que encontra no "festar" uma forma de (re) afirmar os laços sociais (Figura 4).

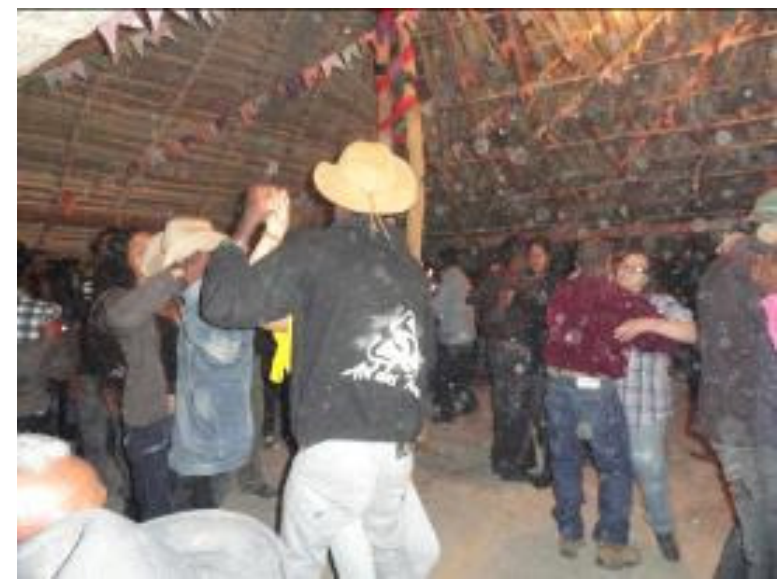

Figura 4: Kalunga e turistas no Forró na Festa de Santo Antônio em Julho de 2011.

Foto: Jorgeanny de Fátima R. Moreira, Julho de 2011.

Figure 4: Forro Kaluga and tourists dancing on the Feast of St. Anthony in July 2011. Photo: Jorgeanny Fatima R. Moreira, July 2011. 
Apesar da perda de algumas de suas práticas simbólicas, como a fabricação de utensílios artesanais e utilização de instrumentos rústicos na agricultura, os Kalunga do Engenho II expressam sua cultura nas manifestações religiosas. "A sociabilidade local é, portanto, construída por meio de agrupamentos de famílias, vinculadas pelo sentimento de localidade, pela convivência, pelas práticas de auxilio mútuo e pelas atividades festivas" (ALMEIDA, 2010, p.14).

As festas que acontecem na comunidade são realizadas com a contribuição de moradores do Engenho II, não há financiamento ou auxílio da prefeitura ou do comércio local. As refeições servidas nas festas são produzidas a partir do envolvimento da população local, tanto com a doação como no preparo dos alimentos.

\section{Desafios e entraves para a efetivação da atividade turística no Engenho II}

No turismo rural as atividades agrícolas não são descartadas, mas continuam a ser desempenhadas pela comunidade. As ocupações ligadas a esse tipo de turismo

[...] de forma alguma, eliminam as atividades agrícolas no espaço em questão, mas contribuem [...], para a complementação da renda familiar, ao possibilitar às famílias de agricultores sua inserção em atividades não-agrícolas (MARAFON; RIBEIRO, 2006, p.120).

Não obstante, no Engenho II a nova atividade econômica é implantada gradativamente, convivendo com as práticas agrícolas, que continuam como fonte principal de renda. A terra é coletiva, os meios de produção pertencem aos moradores da comunidade que contam com a ajuda mútua, de parentes e vizinhos, na época das coIheitas. No entanto, há moradores que trabalham em fazendas vizinhas para a complementação da renda familiar.

A organização do trabalho dos Kalunga na atividade turística, por meio do associativismo, ainda é incipiente, alguns moradores aprovam, enquanto outros acreditam que o turismo não é capaz de melhorar a qualidade de vida da população local. Além disso, existem aqueles que sentem-se intimidados com a presença do visitante, as vezes por timidez ou por não sentir-se confortável com a mudança da rotina, devido ao barulho de carros, vozes e uso intenso dos atrativos.

Uma das moradoras afirma ser impossível ir às cachoeiras com os filhos e esposo nos finais de semana. Nesses dias o fluxo de turistas é intenso, e em alguns casos estão acompanhados por guias vindos do centro urbano de Cavalcante. A moradora conta que sente-se constrangida com tantas pessoas desconhecidas no lugar em que mora. Questionada se tem interesse em aderir aos serviços ligados ao turismo, ela explica que não tem condições financeiras para investir em um empreendimento.

Além do desinteresse e desconfiança de algumas famílias em relação ao turismo, faz-se necessário refletir sobre a degradação ambiental e o impacto cultural 
nessas populações. Em dias de festas, por exemplo, há um aumento considerável de lixo (latas de cerveja, plástico, papel e garrafas de vidro) no Engenho II. Não há coleta desse material, que é queimado por iniciativa dos próprios encarregados das festas. Muitos moradores reclamam dessa atitude, mas concordam que não existe outra opção, já que não há um serviço da prefeitura para remover o material descartado (Figura 5).

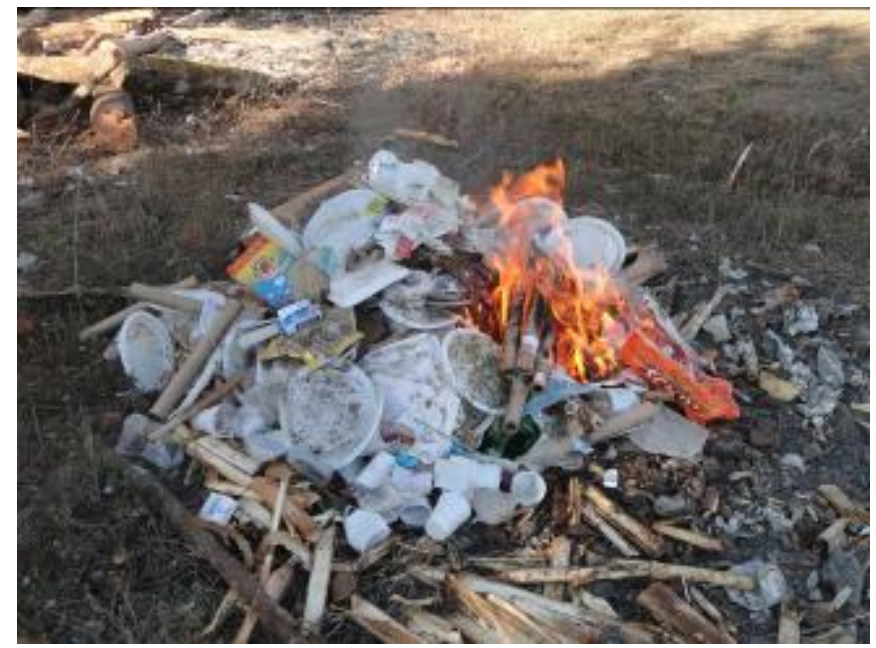

Figura 5: Lixo produzido em uma das festas no Engenho II. Foto: Jorgeanny de Fátima R. Moreira, Julho de 2011.

Figure 5: Waste produced in one of the festivals in the Engenho II. Photo: Jorgeanny Fatima R. Moreira, July 2011.

Essas atitudes não acontecem apenas nos dias de festas, alguns guias locais informaram que muitos turistas deixam plásticos e latas de bebidas no entorno das cachoeiras e das trilhas. Os moradores não conseguem controlar o que os turistas descartam próximos aos atrativos.

A população local tem alternativas para amenizar esses impactos, ao comercializar os produtos mais próximos aos lugares de maior visitação. No entanto, sem orientação, os moradores não se atentam para a oportunidade de eliminar a entrada de produtos adquiridos pelos turistas no centro urbano, e complementar a renda familiar.

Marafon e Ribeiro fazem uma alerta sobre o que falta para o desenvolvimento do turismo no meio rural. Para os autores é fundamental "o envolvimento de órgãos como a Assistência Técnica e Extensão Rural (EMATER), bem como o governo estadual e municipal para a orientação do desenvolvimento de artesanato e doces caseiros, por exemplo" (2006, p. 119).

São poucos os moradores que se dedicam na fabricação de artesanatos ou alimentos para comercialização no Engenho II. A falta de recursos financeiros impede que alguns Kalunga iniciem a fabricação de objetos e alimentos. Os pesquisadores Denardin e Sulzbach (2010), explicam sobre a importância de incentivos para a produção e comercialização de produtos típicos de uma comunidade, ao destacarem o crescimento da procura por produtos de identidade territorial. 
Para esses autores, os produtos produzidos no campo, a partir da agricultura familiar, permitem a esses trabalhadores "uma renda diferencial: uma renda de qualidade territorial" (DENARDIN; SULZBACH, 2010, p. 220). Eles citam exemplos de produtos com identidade territorial, que podem ser materiais ou imateriais, "um queijo produzido artesanalmente em determinado território é um bem" (Idem), da mesma forma que também pode ser considerado um produto com qualidade territorial um grupo folclórico, uma igreja ou gruta, que são símbolos que identificam o território.

F.R. (artesão, agricultor, Kalunga), proprietário de um pequeno alambique, explica seu desejo em aumentar a produtividade, mas não tem capital suficiente para investir em folders ou cartazes para divulgar a cachaça produzida por ele e seus dois filhos. A falta de incentivos e recursos para investimentos também tem provocado a perda de outras práticas, como a fabricação de panelas de barro e de peneiras de folhas dos buritizais.

A produção e comercialização desses materiais podem tornar-se atrativos, uma vez que os artesanatos e alimentos produzidos no campo despertam a atenção dos visitantes. Há relatos na comunidade, sobre algumas famílias que melhoraram a renda familiar com a exploração da atividade turística. Todavia, existem outras que não obtiveram sucesso, devido à dificuldade em se conseguir financiamentos para iniciar o próprio negócio ou pela competitividade entre os empreendedores locais. De acordo com F. R. (condutor de turismo, Kalunga) afirma que os líderes locais ou aqueles que estão envolvidos com a política local se inserem melhor na exploração do turismo.

Existem aspectos negativos na implementação da atividade turística no Engenho II, pois alguns indivíduos dessa comunidade continuam a margem desse processo. A inserção destes na associação, por meio da mobilização e conscientização dos lideres locais, é uma alternativa para apaziguar essas diferenças sociais dentro do próprio grupo.

Além disso, a falta de integração entre a associação e os órgãos públicos ou outras instituições ligadas à cultura e ao turismo de Cavalcante, dificulta o incentivo para a participação mais efetiva de todos os moradores. Segundo o Secretário de Turismo de Cavalcante, já aconteceram minicursos de capacitação para os funcionários municipais envolvidos em projetos da área de turismo, mas a programação dos cursos não possuía foco em serviços de condução.

\section{Considerações finais}

As atividades desenvolvidas na comunidade Kalunga do Engenho II têm se mostrado como estratégia capaz de romper com a dependência desse povo aos sistemas hegemônicos do mercado turístico. Seis dos Kalunga entrevistados veem no desenvolvimento turístico da região, um meio de permanecer no território. Alguns jovens, condutores de turistas, voltaram de cidades como Brasília e Goiânia ${ }^{1}$, pois não conseguiram identificarse ou adaptar-se a rotina dessas metrópoles. A relação de pertencimento com o lugar é forte e preponderante para que muitos resistam ao desemprego e a precariedade de infraestrutura no Engenho II.

No entanto, há grupos que possuem interesses diferentes daqueles que vivem do turismo. Há intenções diversas, como o desejo de continuar o trabalho em suas roças e comercializar o excedente nas cidades; de emigrar para o centro urbano de Cavalcante; de viver em grandes metrópoles, na expectativa de melhores condições de vida; e há o 
grupo dos idosos, que acredita no turismo como meio de atrair forasteiros responsáveis pelo barulho e conflitos na comunidade.

Apesar desses grupos contrários, a exploração turismo rural, étnico e cultural no território Kalunga, pode ser uma oportunidade para o desenvolvimento local, a partir da apropriação de recursos específicos, tanto materiais como imateriais presentes na comunidade do Engenho II.

É evidente que não há o envolvimento de toda a população, e isso provoca conflitos de interesses e ruptura entre os laços historicamente estabelecidos com o lugar, ressaltando a desvalorização da cultura local. O comportamento desinteressado de alguns moradores acrescenta-se ao lugar turístico pautado na efemeridade das relações, entre visitantes e visitados. Na medida em que o turismo rural se consolida com base na economia solidária, a população deve intervir no tipo de turista que deseja na comunidade, estreitando as relações com estes e com o grupo local.

O distanciamento de alguns grupos - contrários ao desenvolvimento do turismo dificulta a criação de mecanismos institucionais, capazes de regular o emprego dos recursos e dos benefícios locais, para o desenvolvimento dessa atividade.

No entanto, é fundamental a participação de todo o grupo social para que se efetive uma organização comunitária, no sentido de difundir e sensibilizar toda a população local acerca das possibilidades para o desenvolvimento social, a partir da exploração dos potenciais naturais e culturais da região.

\section{Referências bibliográficas}

ALMEIDA, M.G. Território de Quilombolas: pelos vãos e serras dos Kalunga de Goiás patrimônio e biodiversidade de sujeitos do Cerrado. Revista Ateliê Geográfico - Edição Especial. V. 1, n. 9, fev 2010, p. 36-63.

ALMEIDA, M.G. Turismo e os Paradoxos no Consumo e Conservação do Ambiente. Revista Ateliê Geográfico. Goiânia: v. 1, n² 2, dez./2007, p. 102-118.

ARRAIS, T.A. Geografia Contemporânea de Goiás. Goiânia: Ed. Vieira, 2004.

BLANCO, E.S. O Turismo Rural em Áreas de Agricultura Familiar: as "novas ruralidades" e a sustentabilidade do desenvolvimento local. In: BARTHOLO, R.; SANSOLO, D.G.; BURSZTYN, I. (Orgs.). Turismo de Base Comunitária: diversidade de olhares e experiências brasileiras. Rio de Janeiro: Letra e Imagem, 2009.

BRASIL. Turismo rural: orientações básicas. Secretaria Nacional de Políticas de Turismo, Departamento de Estruturação, Articulação e Ordenamento Turístico, Coordenação Geral de Segmentação - Brasília: Ministério do Turismo, 2008. 53 p.

BRASIL. Estruturação do produto turístico. Secretaria de Políticas do Turismo. Ministério do Turismo - Florianópolis: SEADIUFSC, 2009.

CAMPANHOLA, C.; SILVA, J.G. O agroturismo como fonte de renda para o pequeno agricultor brasileiro. In: ALMEIDA, J.A.; RIEDL, M. (orgs). Turismo Rural: ecologia, lazer e desenvolvimento. Bauru: EDUSC, 2000.

DENARDIN, V.F.; SULZABACH, M.T. Produtos com Identidade Territorial : o caso da farinha de mandioca no Litoral Paranaense. In: SAQUET, M.A.; SANTOS, R.A. (Orgs). Geografia Agrária, território e desenvolvimento. São Paulo: Expressão Popular, 2010. 
INVING, M.A. Reiventando a reflexão sobre turismo de base comunitária: inovar é possível? In: BARTHOLO, R.; SANSOLO, D.G.; BURSZTYN, I. Turismo de Base Comunitária: diversidade de olhares e experiências brasileiras. Rio de Janeiro: Letra e Imagem, 2009.

MARAFON, G.J.; RIBEIRO, M.A. Agricultura Familiar, Pluriatividade e Turismo Rural: reflexões a partir do território fluminense. Revista Rio de Janeiro. N. 18-19, jan.-dez. 2006.

MINISTÉRIO DA CULTURA. Fundação Cultural Palmares. Disponível em http:// www.palmares.gov.br. Acesso em 14 de Outubro de 2010.

MOLETTA, V.F. Turismo Rural. Série Desenvolvendo o Turismo. Vol. 6. Porto Alegre: SABRAE/RS, 2002.

SANSOLO, D.G.; BURSZTYN, I. Turismo de Base comunitária: potencialidades no espaço rural brasileiro. In: BARTHOLO, R.; SANSOLO, D.G.; BURSZTYN, I. Turismo de Base Comunitária: diversidade de olhares e experiências brasileiras. Rio de Janeiro: Letra e Imagem, 2009.

SWARBROOKE, J. Turismo Sustentável: Meio Ambiente e Economia, vol. 2. São Paulo: Editora Aleph, 2000.

\section{Nota:}

${ }^{1}$ Consumidores que compraram serviços de turismo em pacotes ou em partes nos dois anos anteriores à realização da pesquisa.

Jorgeanny de Fátima Rodrigues Moreira: Universidade Federal de Goiás, Goiânia, GO, Brasil.

Email: jorgeannyf@hotmail.com

Link para o currículo Lattes: http://lattes.cnpq.br/8503948463067223

Maria Geralda de Almeida: Universidade Federal de Goiás, Goiânia, GO, Brasil.

Email:mgdealmeida@gmail.com

Link para o currículo Lattes: http://lattes.cnpq.br/4465452999284335

Data de submissão: 31 de maio de 2012

Data de recebimento de correções: 16 de junho de 2013

Data do aceite: 18 de junho de 2013

Avaliado anonimamente 


\title{
Perspectivas e ações de diferentes atores sociais na gestão e sustentabilidade do turismo em Vargem (SP)
}

\author{
Perspectives and actions of different social actors in the management and \\ sustainability of tourism in Vargem (SP, Brazil)
}

\section{Cristiane Ferraz e Silva Suarez, Nayra de Moraes Gonçalves, João Luiz de Moraes Hoefel}

\begin{abstract}
RESUMO
Este trabalho originou-se da constatação de que a área de estudo, o município de Vargem (SP), vem apresentando diversos problemas, principalmente relacionados ao desenvolvimento do turismo de forma desordenada, decorrentes de variadas alterações socioambientais regionais. O fato de o município estar inserido em uma Unidade de Conservação, a Área de Proteção Ambiental do Sistema Cantareira, enfatiza a necessidade de estudos que contribuam para a elaboração de políticas públicas que possam embasar planos turísticos sustentáveis aliados à conservação dos recursos naturais. Desta forma, este trabalho teve como objetivo identificar perspectivas e ações de diferentes atores sociais na gestão e sustentabilidade do turismo no município. Visando contemplar os objetivos propostos foram adotados procedimentos metodológicos que envolveram levantamentos bibliográficos, trabalhos de campo, nos quais foram realizadas entrevistas e aplicação questionários semiestruturados, bem como a posterior análise dos dados. Os resultados obtidos possibilitaram apresentar uma discussão sobre turismo na visão dos diferentes atores sociais entrevistados e as estratégias e ações existentes para o turismo sustentável e a conservação ambiental em Vargem.
\end{abstract}

PALAVRAS-CHAVE: Gestão; Sustentabilidade; Turismo; Atores Sociais.

\section{ABSTRACT}

This research was developed due to the perception that the study area, the municipality of Vargem (SP, Brazil), has shown several problems, mainly related to tourism development in a disorderly manner, resulting in a variety of regional socioenvironmental changes. The fact that the municipality is inserted in a Conservation Area, the Cantareira System Environmental Protected Area, reinforces the necessity of studies which contribute to the creation of public policies that can support sustainable tourism plans, associated with the conservation of natural resources. Thus, this study aimed to identify different perspectives and actions of diverse social actors in the management and sustainability of tourism in Vargem. Aiming to reach the proposed goals methodological procedures were adopted involving literature surveys, field work, interviews, and the application of semi-structured questionnaires, and the subsequent data analysis. The results allowed to present an analysis of local tourism based on the vision. of the different social actors interviewed and the existing strategies and actions to develop sustainable tourism and environmental conservation in Vargem.

KEYWORDS: : Management; Sustainability; Tourism; Social Actors. 


\section{Introdução}

O planejamento e a gestão do turismo vêm apresentando-se como uma grande preocupação para todos os profissionais interessados na sustentabilidade da atividade. Tal preocupação se fundamenta nos inúmeros exemplos de impactos socioambientais, econômicos e culturais negativos existentes em todo o mundo, decorrentes do crescimento desordenado da atividade turística (SEABRA, 2001).

Torna-se cada vez mais importante promover pesquisas sobre os efeitos da atividade turística na sociedade, tornando-se necessárias propostas de turismo sustentável. Para Gunn (2002) o conceito de turismo sustentável aponta a necessidade de um maior equilíbrio territorial, ambiental e econômico para o desenvolvimento da atividade, requerendo novas abordagens dos setores públicos e privados.

A adoção dos princípios da sustentabilidade pelo turismo, pode transformá-lo em uma atividade com propósitos de crescimento pessoal e comunitário, em prol do bem-estar comum, pela conservação de meio ambiente. Para Ruschmann (2008, p.109), os conceitos turismo e sustentabilidade estão intimamente ligados pois, "encontrar o equilíbrio entre os interesses econômicos que o turismo estimula e um desenvolvimento da atividade que preserve o meio ambiente não é tarefa fácil."

Townsend; Begon e Harper (2006) apontam que uma atividade pode ser considerada sustentável se for continuada ou repetida em um futuro previsível, sem causar danos a sociedade e ao ambiente e, para os autores, a preocupação surge porque grande parte das atividades humanas são insustentáveis.

Dias (2003) cita alguns dos elementos chave da sustentabilidade turística, como por exemplo: a satisfação das necessidades dos visitantes e das comunidades receptoras e a proteção e o melhoramento do atrativo turístico para o futuro por ser parte de um recurso econômico nacional. A relação entre os turistas, as comunidades anfitriãs, os atrativos e o meio ambiente compreende um conjunto complexo de elementos interativos. Cabe reforçar, entretanto, que cada um dos elementos deve manter sua própria continuidade em simbiose com os demais mediante o desenvolvimento de uma relação mutuamente benéfica.

Para Irving et al. (2005), a promoção do turismo sustentável requer uma concepção estratégica e duradoura de desenvolvimento, amparada por um novo olhar sobre as questões sociais, culturais e ambientais dos destinos, aliadas e em interação com a economia globalizada. A Organização Mundial do Turismo - OMT (2001) afirma a necessidade de uma participação ampla, ressaltando que o setor turístico privado também deve cooperar em sua execução, assim como as comunidades locais e os turistas.

Neste cenário, este trabalho teve como objetivo identificar perspectivas e ações de diferentes atores sociais na gestão e sustentabilidade do turismo no município de Vargem, APA do Sistema Cantareira - SP. A análise destas questões no município mostra-se interessante, pois o mesmo vem passando por um processo de urbanização e incremento turístico sem planejamento, responsáveis pelo aumento de impactos e transformações socioambientais locais. Esta situação demanda a realização de estudos que possibilitem a elaboração de planos turísticos sustentáveis e a implementa- 
ção de diversas políticas públicas que permitam a gestão e sustentabilidade do turismo e dos recursos naturais locais.

Dias (2003) define políticas públicas como o conjunto de ações executadas pelo Estado, enquanto sujeito, dirigidas a atender às necessidades de toda a sociedade. Podem ser compreendidas como linhas de ação que buscam satisfazer ao interesse público e têm que estar direcionadas ao bem comum. Contudo, os dois grandes desafios de toda politica pública são a construção de decisões que agreguem consenso entre os diferentes atores sociais e assegurar que as decisões tomadas serão implantadas (RUA, 2006).

Política pública de turismo é compreendida por Cruz (2000) como um conjunto de intenções, diretrizes e estratégias estabelecidas no âmbito do poder público, em virtude do objetivo geral de alcançar o pleno desenvolvimento da atividade turística em determinada localidade. Para Beni (2001), as políticas de turismo são orientações específicas para a gestão diária do turismo, abrangendo os muitos aspectos operacionais da atividade. Neste sentido, uma política de turismo não deve estar voltada apenas para o desenvolvimento do setor, mas deve ser compreendida dentro de um contexto mais geral de uma política pública de desenvolvimento, além de contar com a participação da iniciativa privada e da sociedade civil, a fim de estimular a prática contínua e qualificada da atividade.

Neste contexto, o crescimento acelerado do turismo em áreas protegidas tem gerado debates e posturas divergentes quanto às dificuldades concretas de integrar as políticas públicas do turismo às políticas de gestão ambiental e urbanização. De um modo geral essas políticas têm se mostrado conflitantes e, teoricamente, visam conciliar os interesses econômicos, a preservação e conservação ambiental, considerando os interesses das populações autóctones, com o objetivo de reduzir os impactos negativos sobre o meio ambiente, como também manter essas populações no seu lugar de origem (FADINI; HOEFFEL; SUAREZ, 2007).

Outro aspecto a ser considerado na elaboração de políticas públicas é a participação da sociedade. Nos vários níveis em que possa ocorrer a implementação de uma política pública para o turismo, diversos atores devem ser considerados, inclusive as ONGs, que podem contribuir com resultados mais efetivos da ação governamental.

Dodds e Butler (2009) concordam com esta visão afirmando que a chave para a implementação de políticas bem sucedidas é atribuir mais ênfase a participação local no planejamento das mesmas e sugerem a necessidade de um papel mais integrado entre as políticas de turismo e os múltiplos atores sociais envolvidos no processo, tanto do setor público como privado. Poles e Rabinovici (2010) lembram ainda que um dos maiores desafios para as políticas públicas que regem o turismo é compatibilizar a participação democrática e representativa das comunidades locais na criação e gestão destas políticas.

O termo "governança" pode ser entendido como a capacidade que os governos têm de criar condições e de responder às demandas da sociedade. Em se tratando da governança social ou governança democrática, essa capacidade de governar pressu- 
põe uma administração participativa que envolve as populações locais na elaboração, monitoramento e, em alguns casos, na execução de políticas públicas (BRASIL, 2007).

É importante que a governança tenha como base a transparência e a representatividade dos setores envolvidos com a atividade, deve ocorrer de maneira participativa e compartilhada e definir uma dinâmica de papéis e interações entre os membros da organização, de maneira a desenvolver a participação e o engajamento no processo de decisão. O processo de sensibilização e mobilização dos atores envolvidos, principalmente da comunidade autóctone é essencial.

\section{Caracterização da área de estudo}

O município de Vargem, área de estudo do presente trabalho, está situado na Região Bragantina, a 97 km da capital São Paulo, as margens da Rodovia Fernão Dias, e da Serra da Mantiqueira. Faz divisa com estado de Minas Gerais confrontandose com o município de Extrema (Figura 1).

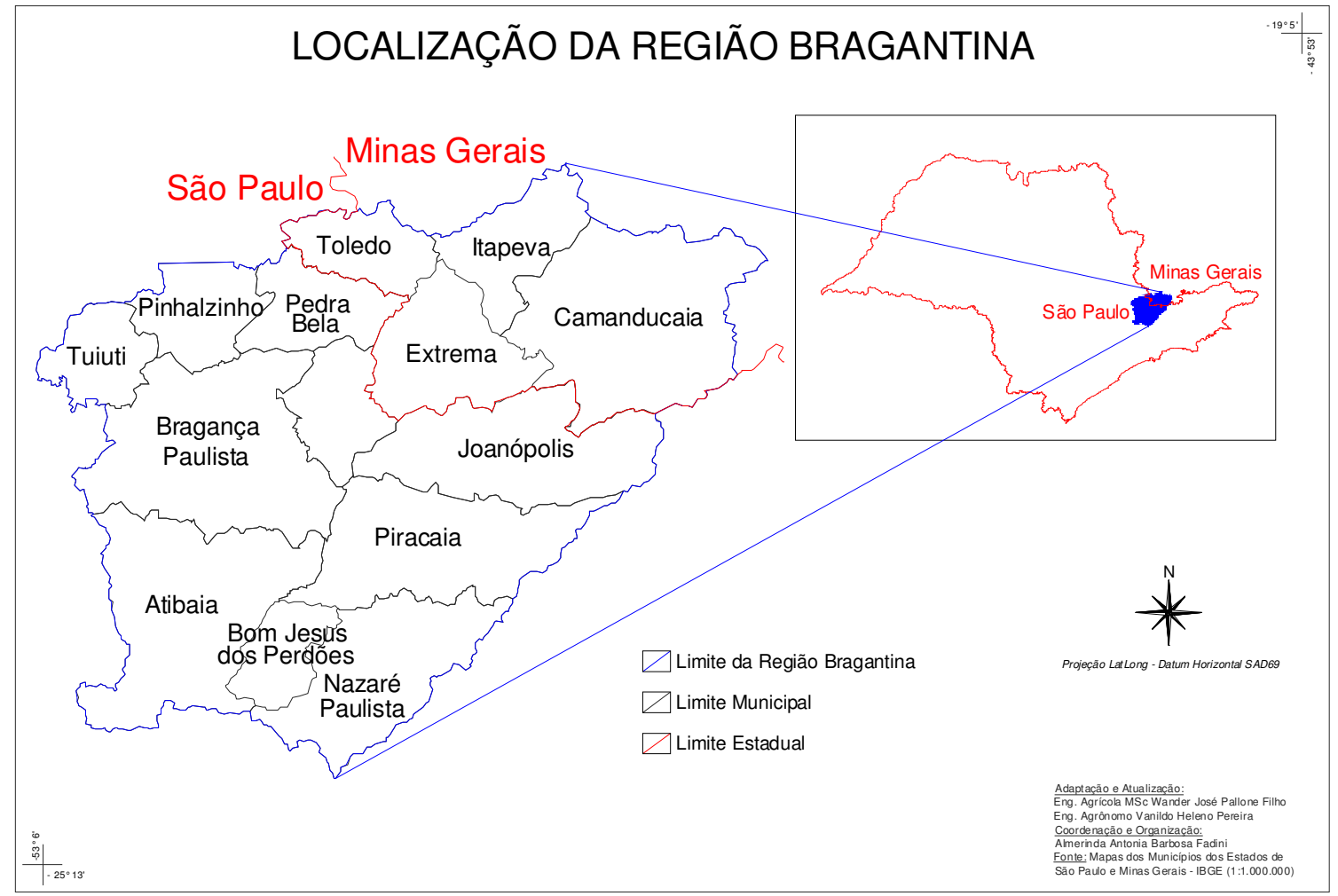

Figura 1: localização do município de Vargem. Fonte: Adaptado do IBGE.

Figure 1: Location of the municipality of Vargem. Source: Adapted from IBGE.

Atualmente no município existem apenas alguns remanescentes de cobertura vegetal nativa concentrados basicamente nas áreas de maior altitude, em especial na 
Serra do Lopo, Serra de Itapetinga, Serras do Arraial, Anhumas e Araras, nas quais ainda encontra-se espécies de fauna e flora características da biodiversidade regional (SILVA et al., 1994) Observa-se que os campos antrópicos predominam neste município em função dos processos econômicos intensivos aos quais esta área foi submetida. Seu perímetro abrange a sub-bacia do Rio Jaguari e do Rio Camanducaia, formadores dos reservatórios Jaguari-Jacareí e, além disso, abriga a cabeceira do Rio Juqueri-Mirim formador do reservatório Paiva Castro. Todos esses reservatórios integram o Sistema Cantareira.

O município integra a APA do Sistema Cantareira, criada a partir da Lei Estadual №. 10.111 de dezembro de 1998, que abrange também os municípios de Atibaia, Bragança Paulista, Joanópolis, Mairiporã, Nazaré Paulista e Piracaia (SÃO PAULO, 2000). Esta APA tem como objetivos, além de garantir a conservação do conjunto paisagístico e da cultura regional, a manutenção e melhoria da qualidade da água, especialmente nos municípios do entorno dos reservatórios dos Rios Jaguary/Jacareí do Sistema Cantareira, que abastecem a Região Metropolitana de São Paulo (RMSP) e regulam o fluxo de água para a Região Metropolitana de Campinas. A APA do Sistema Cantareira é uma Unidade de Conservação ainda em fase de regulamentação, fato que vem intensificando uma problemática ambiental centrada no parcelamento do solo e na conservação de recursos hídricos.

Em função do acesso facilitado a esta região através das Rodovias $D$. Pedro I e Fernão Dias, esta APA vem se tornando alvo de empreendimentos imobiliários diversos, consolidando um processo crescente de ocupação do solo e uso turístico desordenado. Esta expansão urbana, estimulada pelo crescimento da Região Metropolitana de São Paulo rumo a Região Bragantina, e por políticas municipais de incremento urbano, vem ocorrendo de forma intensa e caracteriza-se pela proliferação de loteamentos de alta densidade populacional, implantados sem uma adequada infraestrutura. Dos usos identificados, os mais dinâmicos, impactantes e transformadores são os associados aos processos turísticos e de urbanização (HOEFFEL et. al., 2005).

Neste cenário, a restrição espacial, a cobertura vegetal e os incentivos fiscais restringem o desenvolvimento industrial fazendo da atividade turística, na visão dos gestores e empresários locais, uma das poucas alternativas econômicas possíveis no município. No entanto, verifica-se que esta atividade ainda necessita de planejamento e de políticas públicas adequadas capazes de preservar o patrimônio ecológico, além de maior envolvimento da população local, visando a gestão sustentável do turismo no município.

\section{Metodologia}

Os procedimentos metodológicos utilizados na elaboração deste trabalho envolvem levantamento bibliográfico, pesquisa quanti-qualitativa junto à população local e pesquisa qualitativa exploratória com diferentes atores sociais ligados ao Poder Público, a Sociedade Civil Organizada e a Iniciativa Privada de Vargem. 
Foi realizada uma pesquisa junto à população local a fim de possibilitar a obtenção das respostas das questões enunciadas. Trata-se de uma pesquisa de caráter descritivo onde os fatos foram observados, registrados, analisados, classificados e interpretados por meio de técnicas de coleta de dados como questionários e observação sistemática que, segundo Dencker (2001), pressupõe uma delimitação precisa do campo a ser investigado, tanto no tempo quanto no espaço. Desta forma, foram entrevistados 91 moradores locais, com diferentes perfis socioeconômicos, escolhidos aleatoriamente, distribuídos nos diferentes bairros do município, tanto da área rural quanto urbana. Como instrumento de pesquisa foi utilizado um questionário estruturado, com um roteiro de entrevista composto por 13 questões alternadas entre abertas e fechadas para a obtenção de dados mais objetivos que possibilitaram a confirmação ou rejeição das hipóteses, e neste trabalho serão apresentadas e analisadas as questões mais pertinentes aos objetivos estabelecidos. O questionário foi embasado na metodologia proposta por Dencker (2001) e Ruschmann (2008), que afirmam a importância das perguntas estimularem a memória do entrevistado, sendo ordenadas em seqüência lógica, iniciando com informações socioeconômicas a fim de criar um ambiente de familiaridade entre entrevistador e entrevistado.

A aplicação desses questionários teve como objetivo obter o perfil socioeconômico dos entrevistados e analisar as perspectivas destes com relação ao processo de desenvolvimento turístico no município.

$\mathrm{Na}$ pesquisa com os atores locais foi realizado um levantamento das lideranças, utilizando a técnica do tipo "bola de neve", apresentada por Becker (1994), em que o entrevistado indica outros.

Esta pesquisa foi realizada por meio de entrevistas semiestruturadas, através da utilização de um roteiro composto por 21 questões destinadas aos três grupos estudados (poder público, iniciativa privada e sociedade civil organizada) e mais 06 questões aplicadas especificamente aos empresários do setor hoteleiro (totalizando 26 questões respondidas por estes empresários), das quais serão apresentadas as consideradas mais pertinentes ao tema proposto.

Do Poder Público foram entrevistados 08 gestores em exercício no ano de 2010: a Prefeita do Município de Vargem, o Assessor de Gabinete da Prefeitura, a Diretora do Departamento de Educação, a Diretora do Departamento de Saúde, o Diretor do Departamento de Planejamento, o Chefe da Seção de Gestão Ambiental, o Diretor da Agricultura e Abastecimento e o Presidente da Câmara Municipal de Vargem.

Dentre os representantes da iniciativa privada foram realizadas 04 entrevistas com gerentes e proprietários de hotéis e pousadas locais, representando o setor hoteleiro, 02 com empresários que mais se destacam no ramo de alimentos e bebidas e um com o representante da Companhia de Saneamento Básico do Estado de São Paulo (SABESP).

Foram entrevistados também 03 atores sociais da sociedade civil organizada, atuantes em Organizações Não Governamentais.

Para um melhor entendimento dos dados adquiridos com a realização das en- 
trevistas, os atores sociais foram agrupados em Grupo 1, Grupo 2 e Grupo 3, sendo respectivamente correspondente ao Poder Público, a Iniciativa Privada e a Sociedade Civil Organizada.

\section{Resultados}

\section{A perspectiva dos moradores locais}

O objetivo da primeira parte do questionário foi identificar o perfil socioeconômico dos moradores locais de Vargem, através de questões sobre os dados gerais dos entrevistados.

Em uma breve análise deste perfil verificou-se que a população do município é composta por residentes tradicionais e de migrantes, em sua maioria do estado de São Paulo. Quanto à faixa etária dos entrevistados, em sua maioria, correspondem a uma população jovem e ativa, com 51,6\% com idade entre 21 a 40 anos. Houve uma frequência igualitária em relação ao sexo dos entrevistados com 50,5\% do sexo feminino e $49,5 \%$ masculino. A maioria dos entrevistados $(52,8 \%)$ é casada. Quanto à escolaridade, $33 \%$ dos entrevistados completou o Ensino Médio, uma parcela significativa de $23 \%$ não terminou o Ensino Fundamental e apenas 7,7 \% possui nível Superior completo.

Um aspecto interessante a ressaltar é que, principalmente para os jovens, não há disponibilidade suficiente de emprego, com exceção aos relacionados às atividades tradicionais do município como a agricultura, pecuária, olaria e carvoaria, e esta mão de obra necessita ser alocada nos municípios vizinhos, principalmente ExtremaMG e Bragança Paulista-SP. A renda mensal familiar predominante $(70,2 \%)$ é de até 03 salários mínimos (cabe ressaltar que no período de realização das entrevistas o salário mínimo base era de $\mathrm{R} \$ 465,00)$.

A segunda parte do questionário buscou verificar as perspectivas da população local sobre o turismo no município.

Acerca da importância da implantação de um projeto turístico em Vargem, a maioria dos entrevistados $(84,6 \%)$ considera importante, justificando principalmente que o mesmo incrementa a economia local, desenvolve e divulga o município e gera empregos.

Verifica-se que os moradores locais ressaltam os benefícios econômicos que o desenvolvimento da atividade turística pode gerar, fato que pode ser justificado devido a baixa oferta de empregos no município, o que ocorre, principalmente, pelas restrições ambientais pelas quais o mesmo está sujeito, já que grande parte de sua área corresponde à Área de Preservação Permanente (APP) e que, por estar inserido na APA do Sistema Cantareira, as atividades industriais são restritas.

Uma das justificativas às respostas negativas foi o aumento do custo de vida local ocasionado pelo turismo, o que de fato pode ocorrer caso a atividade turística desenvolva-se de forma espontânea e desorganizada. Portanto, reitera-se a importância da elaboração de um projeto turístico que possa minimizar os efeitos negativos e 
ordenar a atividade.

Sobre a compreensão do conceito de turismo sustentável, a maioria não soube responder, evidenciando a necessidade da adoção de programas de conscientização sobre o conceito, direcionado à comunidade local. No entanto, ainda que as respostas não acompanhem exatamente o que literatura na área considera como turismo sustentável, algumas respostas apresentaram alguns componentes que integram o conceito, considerando pertinente o desenvolvimento do mesmo no município.

Quando questionados sobre os benefícios que o turismo pode gerar para Vargem, os principais pontos citados foram de ordem econômica, como a geração de empregos, o aumento da renda e favorecimento do comércio local, entretanto, alguns autóctones disseram não trazer nenhum benefício. Estas repostas podem representar a falta de conhecimento sobre as possibilidades que o turismo pode gerar no destino ou até mesmo a falta de conhecimento do potencial turístico do município.

Neste sentido, é importante ressaltar, conforme mencionado anteriormente, que a sustentabilidade turística envolve, entre diversos fatores, uma relação adequada entre comunidades receptoras e turistas capaz de gerar oportunidades econômicas e que ao mesmo tempo contribua para a conservação socioambiental na localidade (DIAS, 2003; IRVING et al, 2005; RUSCHMANN, 2008).

\section{A perspectiva dos atores sociais}

Como forma de identificar e conhecer o perfil socioeconômico dos atores sociais que atuam no Poder Público (Grupo 1), na Iniciativa Privada (Grupo 2) e na Sociedade Civil Organizada (Grupo 3) no município de Vargem, a primeira parte do questionário contempla questões referentes à procedência, idade, sexo, estado civil e escolaridade dos entrevistados.

Com relação à procedência, foi possível identificar que a maioria dos entrevistados do Grupo 1 (75\%) nasceu no próprio município, já a maioria dos entrevistados dos Grupos 2 e 3 nasceram em outras cidades do estado de São Paulo. Quanto à faixa etária, a maioria dos três grupos entrevistados tem idade entre 41 a 65 anos com $62,50 \%, 57,14 \%$ e $66,67 \%$ respectivamente.

Com relação ao sexo dos entrevistados houve a predominância do sexo masculino, com 62,50\% do Grupo 1, 71,43\% do Grupo 2 e 100\% do Grupo 3. A maioria dos atores sociais entrevistados do Grupo 1 (87,5\%), do Grupo 2 (57,14\%) e todos do Grupo 3 são casados. Quanto ao grau de escolaridade, a maioria dos entrevistados do Grupo 1 (50\%), Grupo $2(57,14)$ e Grupo 3 (66,67\%) possuem Ensino Superior completo.

A segunda parte do questionário foi estruturada com questões que contribuíram para verificar e analisar as perspectivas e a participação dos atores sociais na gestão e sustentabilidade do turismo na localidade.

A maioria dos entrevistados do Grupo 1 (75\%), Grupo $2(57,14 \%)$ e Grupo 3 $(66,67 \%)$ consideram que as atividades turísticas em Vargem têm influenciado a qua- 
lidade de vida dos moradores locais com o aumento da economia local, da renda e dos empregos no município. Já $25 \%$ do Grupo 1 afirmou que a demanda turística atual não é significativa ao ponto de influenciar a qualidade de vida dos autóctones. Os entrevistados do Grupo 2 e do Grupo 3 acrescentaram ainda que os comerciantes possuem uma visão distorcida do que é a atividade turística e como ela pode beneficiar a população local.

Quanto a motivação do turista para visitar Vargem, a maioria dos entrevistados do Grupo 1 respondeu que é devido a tranquilidade e sossego do município, já os entrevistados do Grupo 2 e do Grupo 3 responderam em sua maioria que é em função os atrativos naturais.

A maioria dos entrevistados de todos os Grupos destacou que a atividade turística em Vargem proporciona desenvolvimento econômico, cultural e social. A geração de empregos também foi um item citado por diversos atores sociais, demonstrando que atividade turística em Vargem é vista como uma das possibilidades de desenvolvimento socioeconômico.

Quando questionados sobre o interesse do turista pela cultura local, a maioria dos entrevistados do poder público respondeu que o turista tem interesse, principalmente, pelas festas religiosas e igrejas locais, mas grande parte dos atores sociais da iniciativa privada e da sociedade civil organizada acredita que o turista não tem conhecimento dos atrativos culturais devido á falta de divulgação dos mesmos, e que, na maioria das vezes, ficam restritos aos meios de hospedagem.

Foi solicitado também aos entrevistados que apontassem os principais problemas de Vargem, e, de acordo com os atores sociais entrevistados, os mais significativos são a falta de recursos para implantação de projetos e realização de eventos no município, a falta de oportunidade de empregos, o sistema precário de saúde e a falta de participação e interesse dos próprios munícipes nas discussões sobre as ações para a cidade.

Para os atores sociais Vargem não apresenta problemas significativos decorrentes da atividade turística, pelo fato da mesma ainda ser incipiente, mas destacam o aumento da quantidade de lixo, principalmente em algumas trilhas e cachoeiras. Destacaram também que o comércio local não está preparado para atender os turistas e que falta um Centro de Informações Turísticas na entrada da cidade, bem como a divulgação da mesma na região.

Os relatos colhidos apontam que todos os atores sociais entrevistados consideram importante a implantação de um Projeto Turístico para Vargem, atribuindo a este a função de alavancar e desenvolver o município e organizar a realização de uma atividade turística sustentável, principalmente considerando que a maioria dos atrativos são naturais e precisam ser explorados de forma não predatória.

Os entrevistados foram estimulados a apresentar algumas propostas para 0 turismo em Vargem, sendo que as que mais se destacaram foram as de investimentos na infraestrutura turística, principalmente em hotéis e restaurantes na área urbana e rural, de maior divulgação do município e seus atrativos, de criação de um centro de 
artesanato municipal que capacite a população local e incentive o desenvolvimento desta atividade, da exploração dos atrativos naturais de forma não predatória e por fim, da criação de rotas de turismo rural, envolvendo os turistas em visitas a fazendas antigas e a propriedades de cultivo orgânico.

Além disso, foi destacada também a importância de se estabelecer parcerias entre empresários, população e Gestão Pública para a implantação de ações voltadas ao desenvolvimento turístico sustentável em Vargem.

Estas questões reforçam a importância da adoção de estratégias que motivem a participação da sociedade local, com destaque para os diferentes atores sociais, na elaboração de políticas públicas para o turismo em todos os seus níveis, desde o diagnóstico até a implementação e avaliação (OMT, 2001; DODDS; BUTLER, 2009). Conforme mencionado por Poles e Rabinovici (2010), estimular e concretizar esta participação apresenta-se como um dos maiores desafios para as políticas públicas de turismo.

\section{Ações de diferentes atores sociais na gestão e sustentabilidade do turismo em Vargem}

A partir das entrevistas foi possível detectar que entre os atores sociais entrevistados, 87,50\% do Grupo 1, 42,86\% do Grupo 2 e 100\% do Grupo 3 têm conhecimento sobre algumas ações/estratégias para o desenvolvimento do turismo sustentável em Vargem, sendo as ações realizadas pela UNICIDADES, em função do Circuito Entre Serras e Águas, as mais conhecida pelos atores sociais, seguidas pelos projetos FAPESP realizados pelo CEA - Universidade São Francisco e pelo NEPAM - Unicamp, que aconteceram no período de 2009 a 2011. Também foram mencionadas as ações da CATI - Coordenadoria de Assistência Técnica Integral - relacionadas ao turismo rural, cursos promovidos pelo Fundo Social, cursos técnicos de Desenvolvimento Turístico e de Meio Ambiente financiados pelo Ministério do Turismo e o Projeto Ponto de Cultura do Ministério da Cultura, além de algumas ações realizadas dentro de hotéis e pousadas e pelas associações.

Todos os entrevistados do Grupo 2 e do Grupo 3 responderam que participam ou estão inseridos no desenvolvimento ou execução dessas ações/estratégias, assim como a maioria $(85,71 \%)$ dos atores sociais entrevistados do Grupo 1. A participação destes atores acontece principalmente nas reuniões e ações realizadas pela UNICIDADES e através da Gestão Pública, na gestão das ações e na elaboração de projetos.

De acordo com os atores sociais do Grupo 1 (85,71\%) e do Grupo 2 (50\%), a maioria das ações/estratégias citadas associam o desenvolvimento turístico com a conservação dos recursos naturais locais e/ou regionais. Como exemplo foram citados o envolvimento da CATI com a questão ambiental em suas ações, principalmente no meio rural e os projetos da FAPESP que buscaram analisar justamente estas questões, as propostas de curso de meio ambiente ligadas ao turismo, visando à conscientização da sustentabilidade para o município, as ações na área da educação ambiental e projetos que envolvem os alunos desde a pré-escola. 
Já $66,67 \%$ dos atores sociais do Grupo 3 acreditam que não e justificam a resposta ressaltando a necessidade de maior integração da Gestão Pública com as ações da UNICIDADES, bem como a necessidade de integração das câmaras técnicas de turismo e meio ambiente na agência de desenvolvimento.

Os relatos dos atores sociais com relação à implementação de ações que estimulem o turismo em Vargem por parte da Gestão Pública atual são polêmicos, uma vez que a maioria $(62,50 \%)$ do Grupo 1, que é composto pelos Gestores Públicos, responderam que a Gestão Pública tem implementado algumas ações neste sentido. Já os entrevistados do Grupo $2(71,43 \%)$, formado pela iniciativa privada, e os entrevistados do Grupo $3(66,67 \%)$, composto por representantes de ONGs responderam que a Gestão Pública não tem realizado ações relacionadas com o turismo no município.

Observa-se, desta forma, a existência de um conflito de percepções e ações entre os atores sociais, principalmente no que tange a questão relacionada à política pública local. Neste sentido, para se alcançar a sustentabilidade turística, é preciso que a atividade seja desenvolvida com o suporte de um adequado planejamento participativo, o qual deverá ser realizado com base em informações provenientes de estudos e análises referentes ao cenário da localidade, bem como das potencialidades de desenvolvimento futuro e envolvimento da comunidade local.

Dentre as ações da gestão pública mencionadas estão a realização de projetos para melhorias na infraestrutura básica e turística, tais como o projeto de criação do teleférico, do parque de lazer municipal, do Portal municipal, do terminal rodoviário, além da organização e participação em eventos turísticos, como a Romaria das águas e esportes radicais como o campeonato paulista de MotoCross, além do Projeto de implantação do Centro de Informações Turísticas e do Projeto "Luzes de natal".

$\mathrm{Na}$ visão dos atores dos Grupos 2 e 3, no entanto, a Gestão Pública não apresenta-se preparada para gerenciar a atividade turística municipal, além de não buscar verbas para este fim.

No que tange a participação da população local nas decisões sobre as ações relacionadas ao turismo, entretanto, parece existir um consenso entre os atores sociais entrevistados, que consideram a população muito apática e pouco participativa e justificaram que realizam a divulgação sobre fóruns, ações e audiências, mas a população não mostra interesse e a grande maioria não comparece.

Esta percepção dos atores se estende também a falta de envolvimento da população nas ações relacionadas às questões ambientais. Uma das dificuldades apresentadas pela gestão pública é o fato do município não ter Conselho Municipal de Defesa ao Meio Ambiente (COMDEMA), nem Conselho Municipal de Turismo (COMTUR) o que dificulta o contato com a população, reiterando a necessidade de reativação destes conselhos para que as ações sejam mais bem articuladas.

Como sugestões para a conservação dos recursos naturais em Vargem foi citado pelos entrevistados dos três grupos de atores sociais a implantação projetos de Educação Ambiental, abordando temas como turismo e meio ambiente. Entrevistados do Grupo 1 mencionaram que seria importante para o município criar legislações específicas 
para a localidade e aumentar a fiscalização pela polícia ambiental e os do Grupo 2 acreditam que é necessário o fomento de parcerias entre iniciativa privada e Gestão Pública para a conservação dos recursos naturais de Vargem. Os entrevistados do Grupo 3 citaram a importância de se realizar trabalhos de conscientização ambiental com os oleiros do município, de reativar o CONDEMA e implantar a coleta seletiva no município.

Quanto à contribuição de cada ator social para a conservação dos recursos naturais locais, os entrevistados, em sua maioria, responderam que já realizam algumas ações de conscientização, gestão ambiental e fortalecimento da cidadania, sempre trabalhando pela causa e reconheceram que podem intensificar estas ações, reciclando os resíduos sólidos, usando a água de forma consciente, não jogando lixo nos rios, denunciando ações predatórias e incentivando o plantio de novas árvores e a não derrubada de matas para a utilização do solo com novas formas de ocupação.

No grupo de organizações não governamentais destaca-se a Associação Entre Amigos de Vargem, que tem por finalidade criar condições para o fortalecimento de atividades associativas, produtivas e promocionais a pessoas carentes de atenção e autoestima. Com relação ao turismo, os membros da associação vêm trabalhando principalmente com a questão ligada ao artesanato local, utilizando em sua maioria a bucha vegetal e sementes como matéria prima e organizando encontros com a comunidade para a disseminação destas práticas, entretanto, reiteram a falta de interesse da maioria dos autóctones em aprender um novo ofício como uma alternativa de renda complementar, principalmente pelo fato do retorno do artesanato ser a longo prazo. Mesmo assim, os membros têm como meta a reativação da construção do barracão da Associação Entre Amigos de Vargem para transformá-lo em um Centro de Artesanato Municipal. A Sociedade Amigos do Rio Acima do Município de Vargem S.A.R.A (Rádio SARA FM) realiza desde 2006 o serviço de radiodifusão comunitária, tornando-a um dos principais veículos de comunicação da localidade. A ONG também foi a responsável pela idealização do projeto Ponto de Cultura junto ao Ministério de Comunicação, que visa à aquisição de equipamentos sonoros e a organização de shows com artistas locais. Outra organização não governamental atuante no município é a Agência de Desenvolvimento Regional - UNICIDADES que possui a proposta de implantação do Circuito Turístico Entre Serras e Águas, uma ação estratégica para o desenvolvimento do turismo regional. O circuito está sendo elaborado pela UNICIDADES, pelo SEBRAE - SP em parceria com as secretarias e departamentos de turismo dos municípios envolvidos e com as instituições de ensino superior, Universidade São Francisco e Universidade de Guarulhos. A UNICIDADES abrange 14 cidades do estado de São Paulo e uma do estado de Minas gerais e tem a missão de mediar o diálogo entre as instâncias públicas e privadas, identificando prioridades estratégicas regionais e articular a viabilidade de execução de programas e projetos nestes municípios.

No âmbito do turismo destaca-se a implantação do Projeto de Desenvolvimento Territorial com Foco no Turismo, através da criação do Circuito Entre Serras e Águas e, para tal, possui uma Câmara Técnica de Turismo, formada por um grupo gestor composto por quatro representantes de cada município envolvido, responsáveis 
pela articulação dos diversos segmentos e entidades de interesse turístico e da comunidade para o desenvolvimento do turismo sustentável no circuito regional.

O objetivo geral é promover o desenvolvimento sustentável do turismo, possibilitando melhorias nas condições socioeconômicas e ambientais do território. Dentre os resultados esperados, destacam-se a intenção de aumentar o fluxo de turistas nos municípios que integram o Circuito; a formatação produtos turísticos atrativos comercializáveis; a formatação de quatro roteiros turísticos no território do Circuito Entre Serras e Águas; aumentar em 10\% o número de refeições vendidas; estruturar cinco pontos de venda de produtos artesanais de qualidade e a implantação de sinalização turística na zona urbana e rural em três municípios do Circuito Entre Serras e Águas;

De acordo com a entrevista com a coordenadora da câmara técnica de turismo da UNICIDADES, as principais dificuldades encontradas para a implantação do projeto em Vargem são a sensibilização da comunidade e da gestão pública e privada sobre a importância da participação do município no circuito e a consequente falta de apoio para a realização das atividades que precisam ser desenvolvidas para tal. Segundo a coordenadora, Vargem se encontra neste momento na fase de elaboração do plano de Marketing do Circuito e estão sendo realizadas visitas dos profissionais da agência de eventos para conhecer os atrativos e coletar demais informações pertinentes para o plano.

Na sua visão, os benefícios que a participação no circuito pode trazer para Vargem estão relacionados à maior visibilidade no contexto regional, a participação do município em eventos importantes da área como o "Revelando São Paulo" e o "Salão do Turismo" sem custos, a consultoria para o desenvolvimento de roteiros turísticos e a realização de cursos de capacitação. A coordenadora ressalta que o papel da Gestão Pública de Vargem no projeto é ajudar na formatação dos roteiros, material de divulgação, fornecer dados sobre o município, disponibilizar recursos humanos para acompanhar as visitas de campo na cidade e reativar o COMTUR (isto ainda não foi feito e é fundamental).

O engenheiro responsável pelo Centro de Educação Ambiental - Observatório de Manaciais, localizado em Vargem, informou que a Companhia de Saneamento Básico do Estado de São Paulo - SABESP vem atuando como parceira na conservação dos recursos hídricos locais, principalmente, abrindo espaço neste centro para a realização de atividades de educação ambiental junto à comunidade, através das escolas em parceria com a gestão publica.

Em relação aos meios de hospedagem, como ação realizada para contribuir com a conservação dos recursos naturais em Vargem, foram citadas o envolvimento dos hóspedes em atividades de reflorestamento dentro da pousada, o investimento em ações relacionadas aos esportes radicais e à educação ambiental com hóspedes durante as trilhas, além de estimular o plantio de árvores na propriedade e a colheita de produtos orgânicos produzidos no local. Um dos gerentes dos hotéis pesquisados informou que o hotel possui tratamento de água e esgoto e que os monitores passam informações sobre preservação ambiental aos hóspedes.

Quanto às pesquisas do Centro de Estudos Ambientais - Sociedades e Naturezas - Universidade São Francisco e Núcleo de Estudos AmbientaisUNICAMP, o envolvimento destas duas Instituições de Ensino Superior aconteceu em 
função dos projetos realizados na região, apoiados pela FAPESP (processos n. 06/60366 -5 ; n. 2007/59833-0 e n.2006/51790-8), da realização da tese de doutoramento de Cristiane Ferraz e Silva Suarez, vinculada ao NEPAM-UNICAMP, cuja pesquisadora também é docente da Universidade São Francisco. Várias ações foram realizadas decorrentes destas parcerias que se estenderam à Prefeitura Municipal de Vargem e a CATI. Dentre as ações, foram realizados encontros para a apresentação dos resultados do trabalho e discussão das propostas com alguns segmentos da sociedade, incluindo instituições governamentais, comunidade acadêmica e organizações não governamentais.

Estes encontros foram extremamente enriquecedores para todos os atores e, em especial, para o fortalecimento do espírito participativo em formulação de políticas públicas que visem à sustentabilidade do turismo em Vargem. Lembrando que cabe aos atores sociais, a partir de sua participação e tomadas de decisão, a exigência da incorporação destas propostas pelo poder municipal.

Verificou-se, portanto, através das pesquisas a existência de um trabalho interdisciplinar que envolve parcerias entre o setor público, a iniciativa privada e a sociedade civil organizada para ações que visam à sustentabilidade do turismo em Vargem, contudo, estas parcerias se mostram um pouco fragilizadas, considerando que seus gestores necessitam dispor de um planejamento turístico bem elaborado que direcione os rumos para o turismo local na perspectiva da sustentabilidade, e de pessoal técnico capacitado para atuar na área do turismo, uma vez que não existe um departamento específico para este segmento na atual estrutura de gestão municipal.

\section{Considerações}

Considerando que esta pesquisa teve como objetivo identificar perspectivas e ações de diferentes atores sociais na gestão e sustentabilidade do turismo no município de Vargem-SP, foram adotados procedimentos metodológicos que incorporaram três fases, sendo a exploratória, o trabalho de campo e a análise dos dados obtidos.

Com relação às ações e estratégias adotadas pelos diferentes atores sociais entrevistados, relacionadas à gestão e a sustentabiliadde do turismo, foi possível observar que o poder público municipal vem participando, ainda que de forma incipiente, no desenvolvimento do turismo local.

Destaca-se também a importância dos gestores municipais buscarem parcerias com os empresários da localidade e da região, principalmente os relacionados à oferta turística, e com as associações e ONGs preocupadas com a conservação dos recursos naturais locais, uma vez que a problemática ambiental é evidente na região, somada ao fato do município estar inserido dentro de uma Área de Proteção Ambiental - a APA Cantareira.

Outra questão é a constatação, por meio da pesquisa com os moradores locais que, embora algumas ações já estejam acontecendo, elas não têm se dado de forma integrada entre o poder público e a comunidade local. Esta questão, no entanto, é um pouco polêmica, pois segundo os diferentes atores sociais entrevistados, a população não se motiva a participar e discutir as ações direcionadas ao turismo e ao meio ambiente no município, fato que dificulta esta integração. Do ponto de vista da comunidade local, a gestão 
pública não envolve a população no processo de tomada de decisão.

Quando se almeja realizar atividades turísticas dentro de uma Área de Proteção Ambiental, entretanto, tem que se pensar em ações e práticas sustentáveis no que se refere aos recursos naturais, no bem estar e na qualidade de vida dos moradores e dos turistas que ali visitam.

Desta forma, para que a gestão da atividade turística em Vargem se desenvolva dentro dos critérios da sustentabilidade, necessita-se de práticas que incorporem a integração e o estímulo à participação de todos os atores sociais envolvidos, considerando os arranjos produtivos locais e respeitando as singularidades com vistas aos benefícios para a comunidade. Isto requer a participação tanto do poder público quanto da iniciativa privada e da comunidade local.

\section{Referências bibliográficas}

BECKER, H.S. Métodos de Pesquisa em Ciências Sociais. São Paulo: Hucitec, 1994.

BENI. M. C. Análise Estrutural do Turismo. 2ª ed. São Paulo: Senac, 2001.

CRUZ, R. C.A. Política de turismo e território. São Paulo: Contexto, 2000.

DENCKER, A F.M.; CHUCID da VIÀ, S. Pesquisa empírica em ciências humanas. São Paulo: Futura, 2001.

DIAS, R. Turismo sustentável e meio ambiente. São Paulo: Atlas, 2003.

DODDS, R.; BUTLER, R. W. Inaction More than Action: Barries to the implementation of Sustainable Tourism Policies. In: GOSSLING, S.; HALL, M.C. WEAVER, D.B. Sustainable tourism futures: perspectives on systems, restructuring, and innovations. New York and London: Routledge, 2009.

FADINI, A.B., HOEFFEL, J.; SUAREZ, C. Parcerias Ambientais: diagnóstico turístico e propostas de educação ambiental em Vargem - SP, Projeto de Pesquisa de Políticas Públicas 06/51790-8, FAPESP, 2007.

GUNN, C.A. Tourism Planning: basics concepts cases. $4^{\text {th }}$ ed. London: Routledge, 2002.

HOEFFEL, J. L.; FADINI, A.A.B; MACHADO, M. K.; REIS, J.C. Trajetórias do Jaguary - a complexidade sócio-ambiental no Reservatório dos Rios Jaguary/Jacareí. Annals of Proceedings International Congress on Environmental Planning and Management. Brasília: Catholic University of Brasília, 2005, p. 1-16 (CD Rom).

IRVING, M.A.; BURSZTYN, I.; SANCHO A.P. Revisitando significados em sustentabilidade no planejamento turístico. Caderno Virtual de Turismo,v.5, n.4, p.1 -6, 2005.

ORGANIZAÇÃO MUNDIAL DO TURISMO - OMT. Introdução ao turismo. São Paulo: Roca, 2001.

POLES, G.; RABINOVICCI, A. O ambientalismo, o turismo e os dilemas do desenvolvimento sustentável. In: NEIMAN, Z.; RABINOVICI, A. Turismo e meio ambiente no Brasil. Barueri, SP: Manole, 2010. 
RUA, M.G. Turismo e políticas públicas de inclusão. In: Turismo social: diálogos do turismo, uma viagem de inclusão. Ministério do Turismo, Instituto Brasileiro de Administração Municipal. Rio de Janeiro: IBAM, 2006.

RUSCHMANN, D.V.N. Turismo e Planejamento Sustentável: a proteção do meio ambiente. Campinas: Papirus, 2008.

SÃO PAULO. Secretaria de Estado do Meio Ambiente. Atlas das Unidades de Conservação Ambiental do Estado de São Paulo. São Paulo: SMA, 2000.

SEABRA, G.F. Ecos do turismo: O turismo ecológico em áreas protegidas. Campinas: Papirus, 2001, p. 74, 220-221.

SILVA, A.C.Q.; TRAVASSOS, A.I.P.; BLANCO, C.R.F.; ARRUDA, C.C.; MARQUES, E.G.L.; PEGORARO, J.L. Vargem/SP- Meio Biológico. In: HOEFFEL, J. L. M. (org.). Ambiente de Vargem: diagnóstico crítico. Itatiba: Universidade São Francisco, p. 85-120, 1994.

Cristiane Ferraz e Silva Suarez: Universidade São Francisco, Bragança Paulista, SP, Brasil. Email: cristiane.suarez@saofrancisco.edu.br Link para o currículo Lattes: http://lattes.cnpq.br/7955383731847589

Nayra de Moraes Gonçalves: Moinho d'Água Treinamentos, Atibaia, SP, Brasil. Email: nayragoncalves@gmail.com Link para o currículo Lattes: http://lattes.cnpq.br/9703941932203592

João Luiz de Moraes Hoefel: Núcleo de Estudos em Sustentabilidade/Faculdades Atibaia (NES/FAAT), Atibaia, SP, Brasil.

Email: jlhoeffel@gmail.com

Link para o currículo Lattes: http://lattes.cnpq.br/7635072427530391

Data de submissão: 31 de maio de 2012

Data de recebimento de correções: 21 de junho de 2013

Data do aceite: 01 de julho de 2013

Avaliado anonimamente 
Moraes, E.A.; Irving, M.A. Ecoturismo: encontros e desencontros na Reserva Extrativista do Cazumbá-Iracema (AC). Revista Brasileira de Ecoturismo, São Paulo, v.6, n.3, ago/out2013, pp.738-757.

\title{
Ecoturismo: encontros e desencontros na Reserva Extrativista do Cazumbá-Iracema (AC)
}

\author{
Ecotourism: agreements and disagreements in Extractive Reserve \\ Cazumbá-Iracema (AC, Brazil)
}

\section{Edilaine Albertino de Moraes, Marta de Azevedo Irving}

\section{RESUMO}

O ecoturismo tem sido interpretado como uma alternativa possível para o desenvolvimento local em associação às Unidades de Conservação. Para a categoria de manejo de UC Reserva Extrativista, especialmente na Amazônia brasileira, o ecoturismo tem sido discutido também como possibilidade de uso múltiplo dos recursos florestais. Com este enfoque, este artigo busca analisar como os moradores do Núcleo do Cazumbá (Reserva Extrativista do Cazumbá-Iracema - Acre) interpretam o ecoturismo, em seu panorama atual e futuro. A metodologia baseou-se em pesquisa bibliográfica e documental, observação participante, realização de entrevistas semiestruturadas e projetivas e rodas de conversa com os interlocutores selecionados. Os principais resultados obtidos revelaram que os interlocutores da pesquisa entendem o ecoturismo como potencialidade para o desenvolvimento local, em uma perspectiva de longo prazo. Mas para tal, é ainda necessária a sua mobilização e organização, a partir da decisão coletiva e do controle social do processo de planejamento e de implementação do ecoturismo, com o compromisso de melhoria da qualidade de vida e proteção do patrimônio natural e cultural .

PALAVRAS-CHAVE: Ecoturismo; Unidades de Conservação; Reserva Extrativista do Cazumbá-Iracema.

\section{ABSTRACT}

Ecotourism has been interpreted as a possible alternative for local development in association with Protected Areas. For the category Extractive Reserve, especially in the Brazilian Amazon, ecotourism has also been discussed as possibility of multiple use of forest resources. With this approach, this paper analyzes how the residents of the Core Cazumbá (Extractive Reserve Cazumbá-Iracema - Acre) interpret ecotourism in their current situation and future. The methodology was based on literature and documents, participant observation, semi-structured interview, projective technique and through conversations with selected partners. The main results showed that the research partners understand how ecotourism potential for local development in a long-term perspective. But to do so, it is still necessary to their mobilization and organization, from the collective decision and social control of the process of planning and implementation of ecotourism, with a commitment to improving the quality of life and protection of natural and cultural heritage.

KEYWORDS: Ecotourism; Protected Areas; Extractivist Reserve Cazumbá-Iracema. 


\section{Introduzindo o tema}

A proposta de Reserva Extrativista (RESEX) se originou no Movimento Seringueiro, na década 1980, no Estado brasileiro do Acre. Este modelo de uso do território foi concebido sob a lógica de integração sociedade e natureza, para a conservação dos recursos naturais e a proteção dos modos de vida e da cultura das populações tradicionais. Por sua origem, a categoria de manejo de Unidade de Conservação RESEX é defendida por vários segmentos da sociedade civil organizada, como uma alternativa para o desenvolvimento social, econômico e cultural da Amazônia brasileira.

Consideradas como Unidades de Conservação (UCs) de Uso Sustentável pelo Sistema Nacional de Unidades de Conservação - SNUC (BRASIL, 2000, 2002), as RESEX são baseadas na economia extrativista, que orienta o uso múltiplo dos recursos naturais. Mas o processo de implementação dessas UCs é complexo e requer novas alternativas econômicas e tecnologias conjugadas a estudos de mercado, que considerem a dinâmica socioambiental nessas áreas naturais protegidas. Sendo assim, o processo de implementação de uma RESEX é lento e dependente de organização social e política, além de demandar recursos financeiros para o fortalecimento das cadeias produtivas extrativistas (ALEGRETTI, 2004). Mas mesmo diante das dificuldades de implementação dessas UCs, é possível notar que, desde o seu surgimento, várias iniciativas têm sido realizadas para a expansão dessa categoria de manejo em todo o território nacional.

Um importante argumento para o reconhecimento e a difusão desta categoria de manejo de UC, segundo Murrieta e Rueda (1995), reside na possibilidade de uso múltiplo da floresta, por meio do aproveitamento das potencialidades de sua biodiversidade. Com este enfoque, a possibilidade de uso múltiplo da floresta, e a prática do ecoturismo em particular, tendem a representar importantes alternativas econômicas para o fortalecimento da cultura local e para a redução da pressão sobre os recursos naturais renováveis (MORAES; IRVING, 2007).

Mas considerando que as primeiras RESEX surgiram na Amazônia brasileira, é importante entender que, o ecoturismo nessa região tem sido desenvolvido dissociado de estratégias de planejamento centradas em uma discussão ética sobre sustentabilidade, o que vem colocando, frequentemente em risco, a proteção do patrimônio natural e cultural da região, causando crescentes impactos e exclusão das populações locais. Em realidade, pode-se interpretar que o ecoturismo na região é, em geral, sazonal e se limita à hospedagem em "hotéis de selva" e a algumas excursões pelos rios amazônicos. Mas a dificuldade de acesso, o custo, a limitação de infraestrutura em algumas localidades, e até mesmo o receio dos visitantes pelos efeitos de doenças tropicais, como a malária, são justificativas constantemente citadas como problemas ao uso turístico da região. E de forma contrastante a estes problemas, o apelo à proposta de ecoturismo na Amazônia decorre da percepção associada ao seu elevado valor ecológico (capital natural) e também ao seu valor simbólico, no plano global.

Frases como "Ecoturismo: Desbrave a beleza selvagem da Amazônia"1 são, frequentemente, utilizadas em peças publicitárias de pacotes de viagens à região, com forte inspiração no "mito moderno da natureza intocada"2. Mas apesar deste ape- 
lo, alguns pesquisadores acreditam que o turismo pode ser prejudicial à região, tendo em vista os impactos possíveis decorrentes da exploração de mão de obra e da base de recursos naturais e culturais, estes entendidos apenas como atrativos. Outros percebem o ecoturismo como uma alternativa possível para a proteção da biodiversidade. Ou seja, a noção de ecoturismo, na região, é marcada por sentidos distintos, sobretudo, com relação aos inúmeros significados e subjetividades vinculados à biodiversidade amazônica.

E razões diversas impedem o avanço dessa prática, tal como argumenta Irving (2006, p.46), para a qual o ecoturismo na Amazônia brasileira representa ainda uma "projeção distante na economia local, como uma possibilidade remota no mundo globalizado". No entanto, esta é uma questão central para a reflexão acadêmica e para o contexto atual de políticas públicas, quando se discutem alternativas "sustentáveis" para a subsistência e a inserção das populações amazônicas na cadeia produtiva regional.

É no sentido de contribuir para esta reflexão, que este artigo tem como foco a interpretação do ecoturismo sob a ótica local, na Reserva Extrativista do CazumbáIracema, localizada em Sena Madureira (AC). Esta Resex é considerada uma importante unidade de conservação federal por abrigar uma amostra expressiva da sociobiodiversidade amazônica. Com este intuito, o artigo busca interpretar as percepções dos atores locais e interlocutores institucionais sobre o ecoturismo como alternativa possível para o desenvolvimento local.

Para tanto, os caminhos metodológicos de pesquisa se fundamentaram, basicamente, em revisão bibliográfica e documental, e levantamentos de campo. Os recursos metodológicos da pesquisa de campo foram: roteiro de entrevista semiestruturada e projetiva, observação participante e rodas de conversa.

A maioria das entrevistas foi dirigida a alguns moradores locais, os quais foram selecionados por meio da técnica "bola de neve"3 (LINCOLN; GUBA, 1985 apud ALVES-MAZZOTTI; GEWANDSZNAJDER, 2004, p.163). Sob essa orientação, os sujeitos entrevistados e participantes das rodas de conversa foram 19 residentes fixos do Núcleo do Cazumbá, que participaram do processo de luta pela criação da Reserva Extrativista, e estiveram envolvidos na implementação das primeiras pousadas no local, com papéis reconhecidos de liderança na organização das atividades cotidianas locais. Algumas entrevistas foram direcionadas a oito interlocutores institucionais estratégicos com atuação reconhecida nas ações ambiental e turística na área de influência da unidade de conservação. Neste caso, foram entrevistados os representantes do Escritório Regional do Instituto Chico Mendes da Conservação da Biodiversidade ICMBIO em Sena Madureira ${ }^{4}$; da Secretaria Municipal de Meio Ambiente de Sena Madureira - SEMA; do World Wildelife Found - WWF-BR (escritório de Rio Branco/AC), da Secretaria de Esporte, Turismo e Lazer do Estado do Acre, da Diretoria de Unidades de Conservação de Uso Sustentável ${ }^{5}$ - DIUSP/ICMBIO/MMA, da coordenação do Programa de Desenvolvimento do Ecoturismo na Amazônia Legal - PROECOTUR/ PNE/MMA, do Conselho Nacional dos Seringueiros - CNS, e do Grupo de Trabalho Amazônico - GTA. A sistematização e a análise dos dados obtidos foram realizadas 
por meio de uma adaptação da Análise de Conteúdo de Bardin (1994). Este processo envolveu a ordenação temática dos trechos das entrevistas, com relação ao contexto do ecoturismo em seu panorama atual (significado, potencialidades, benefícios esperados, impactos indesejáveis e obstáculos) e em uma perspectiva futura (demandas locais, interesse de participação no processo e desafios).

Sob esta abordagem, o artigo está estruturado em duas seções principais. A primeira aborda a fundamentação teórica norteadora para esta reflexão, envolvendo as principais questões conceituais sobre ecoturismo em unidades de conservação, na contemporaneidade, para orientar a análise do caso específico das Reservas Extrativistas, em seus princípios e relevância no contexto amazônico. Em seguida, busca-se caracterizar a Reserva Extrativista do Cazumbá-Iracema, considerando-se o seu contexto socioambiental e a percepção sobre o ecoturismo, através da voz dos seus protagonistas, os moradores locais, sendo esta análise complementada pela leitura institucional sobre o tema.

\section{Ecoturismo em Unidades de Conservação: Questões conceituais norteadoras}

A noção de ecoturismo, tal como se discute na contemporaneidade, surge a partir do despertar da sociedade global para a proteção da natureza, a partir das décadas de 1970 e $1980^{6}$. E desde então, na sociedade contemporânea, a "natureza intocada" torna-se pretexto para a descoberta, a aprendizagem e o espírito de aventura, sendo também apropriada como argumento valioso de mercado. Nesta percepção, a noção de ecoturismo, em sua origem, teve como inspiração o processo das viagens dirigidas ao ambiente natural preservado, sendo, progressivamente, ressignificada como uma possibilidade de uso sustentável dos recursos naturais renováveis, através de uma nova concepção de turismo ${ }^{7}$.

Seguindo esta perspectiva, diversos estudiosos destacam um aumento progressivo de turistas, cada vez mais interessados em conhecer destinos ligados à natureza preservada, como alternativa às formas convencionais de lazer e viagens. $E$ a partir desta tendência pelo contato com a natureza, as empresas turísticas passam a entendê-la como uma grande oportunidade de negócio. Desta forma, os destinos turísticos associados à "natureza preservada", qualificados pelo "eco", passam a representar uma oportunidade em termos de diferencial competitivo de mercado.

Assim, Pires (2002) menciona que o aumento de demanda pelo ecoturismo se acentua, sobretudo a partir da década 1990, atingindo países da América Latina (como o Brasil), África e Ásia, e principalmente, os países pioneiros nesta prática, como o Peru, Costa Rica, Senegal e Suriname. Paralelamente a este movimento, parece também evidente um crescente interesse pelo tema, por parte da esfera governamental, principalmente, nos países em desenvolvimento, que apostam na potencialidade do ecoturismo para a geração de renda e emprego, além de estratégia possível para a proteção da biodiversidade. Da mesma forma, as organizações não governamentais, sobretudo, aquelas de cunho ambientalista, passam a se interessar por este processo e, a se inserir, cada vez mais, na discussão sobre ecoturismo.

Para a União Internacional para a Conservação da Natureza (UICN): 
Ecoturismo consiste em viagens ambientalmente responsáveis com visitas a áreas naturais relativamente sem distúrbios, para desfrutar e apreciar a natureza, juntamente com as manifestações culturais do passado ou do presente que possam existir, e que ao mesmo tempo promove a conservação, proporciona baixo impacto pelos visitantes e contribui positivamente para o envolvimento socioeconômico ativo das populações locais (CEBALLOS-LASCURÁIN, 2002, p.27).

Seguindo esta linha conceitual, a importância econômica, social e ambiental do ecoturismo tem sido reconhecida, em nível mundial, com a designação de 2002, como o Ano Internacional do Ecoturismo, pela Organização das Nações Unidas (ONU), com o apoio da Organização Mundial de Turismo. No mesmo ano, foi oficializada, durante a Cúpula Mundial Rio+10, a Declaração de Quebéc, documento norteador para o ecoturismo no mundo, com o objetivo de estimular governos, o setor empresarial, populações receptoras e os próprios turistas a dedicarem esforços para que o ecoturismo se consolide como uma alternativa viável para o desenvolvimento local ${ }^{8}$ e melhoria de qualidade de vida dos grupos humanos diretamente envolvidos no processo.

Mas anos antes da Declaração de Quebéc, em 1994, no Brasil, já haviam sido elaboradas as "Diretrizes para uma Política Nacional de Ecoturismo" pelo Grupo de Trabalho Interministerial em Ecoturismo (Ministério da Indústria, Comércio e Turismo e o Ministério do Meio Ambiente e da Amazônia Legal), entendendo ser esta uma alternativa que compatibiliza, em tese, a proteção do patrimônio natural e cultural, incentiva a sua conservação, promove a formação de uma consciência ambientalista e o bem-estar das populações envolvidas (BRASIL, 1994).

Apesar disso e mesmo considerando o ecoturismo sob a ótica dos discursos oficiais, Fennel (2002, p.175) o define como um processo "reembalado e produzido em massa, na expectativa de aumentar a sua participação no mercado". Complementando o debate, Irving (2008) assinala que, é nesse movimento que emerge um perfil de demanda elitizada, associado a um público capitalizado e disposto a pagar pelo "encontro" com o ambiente natural, "inflacionado" pela crescente comoditização da natureza.

Contudo, como se pensar as tendências para o ecoturismo no Brasil no século XXI? No ranking de países mais visitados em 2011, segundo avaliação do Fórum Econômico Mundial, o país ocupou apenas a $52^{\underline{a}}$ posição, mas alcançou o $7^{\circ}$ lugar nas Américas (WEFORUM, 2010). E também no contexto internacional, o país representa uma das 12 nações que abrigam $70 \%$ da biodiversidade total do planeta (IBGE, 2008), tendo alcançado, no ranking global, a condição de $6^{\mathrm{a}}$ economia mundial (BRASIL, 2012). Mas apesar de todas as suas potencialidades, ironicamente, o Brasil continua ícone no ranking dos países mais pobres e desiguais do mundo.

Com este cenário, evidentemente, o ecoturismo no Brasil tende a resultar de uma tensão entre potencialidades/vulnerabilidades, e inúmeros são os riscos de impactos indesejáveis em seu desenvolvimento. Esse argumento pode ser evidenciado também por várias pesquisas realizadas e exemplificadas por estudos de caso, a par- 
tir dos quais é possível afirmar que, de modo geral, a forma como o turismo se desenvolve em áreas naturais tende a gerar mudanças rápidas e, em alguns casos, indesejáveis e irreversíveis (DIEGUES, 1997; PRADO, 2003).

Mas embora haja divergências quanto aos impactos ocasionados no local receptor pelo turismo, é inegável que diferentes culturas interagem no processo, propiciando que visitantes e visitados vivenciem a perspectiva de alteridade. Ainda por esta razão, seria fundamental que os estudos contemporâneos sobre ecoturismo se orientem também por uma perspectiva antropológica (defendida por Steil, 2006), que procure apreender a relação entre turistas e moradores locais segundo um universo de experiências de mediações concretas, no qual se definem e redefinem as identidades culturais. Sob este ponto de vista, as questões de reflexão transcendem aquelas relacionadas aos impactos do turismo sobre as populações locais e de que forma estas podem resistir às transformações que vêm "de fora", e incidem sobre a maneira como os grupos locais e os turistas negociam suas identidades, no ambiente vivenciado. E, neste caso, atores locais e turistas são percebidos como protagonistas e não apenas "produtores" e "consumidores" no processo.

Construindo-se então uma nova perspectiva de conhecimento e prática para o ecoturismo, partindo-se, sobretudo dos debates propostos por Irving (2008) e Moraes (2009), entende-se que, para além do mercado, o turista busca, geralmente, o contraponto com a vivência do dia-a-dia, a oportunidade de experiência integral de valor imaterial, afetivo, simbólico e espiritual, a partir do encontro com a natureza e a cultura de uma localidade, sendo a sociobiodiversidade, e não apenas a natureza em estado virgem, o principal fator inspirador de deslocamento. A partir destes pressupostos não seria mais possível interpretar o ecoturismo apenas como uma atividade econômica e uma viagem orientada para a natureza, mas essencialmente, como um conjunto complexo de práticas sociais, culturais e políticas, orientado pelo comprometimento com os interesses das populações envolvidas, a partir da perspectiva do encontro.

Por esta via de interpretação e sendo o ecoturismo reconhecido, nos anos recentes, como uma importante alternativa para a promoção do desenvolvimento local, muitos autores argumentam que a garantia da participação social no processo se constitui em elemento central para o seu êxito, tendo em vista que este compromisso favoreceria a interação entre diferentes atores sociais locais para a definição e controle do espaço comum e do destino coletivo. No entanto, não se pode ignorar que, nessa relação dialógica, como em qualquer relação humana, ocorrem posturas de poder que incidem e se manifestam em níveis distintos, em função dos interesses, valores e percepções dos envolvidos. Este processo deve assim envolver o respeito ao outro e garantir a representatividade dos diferentes interesses no processo de tomada de decisão, o que significa a adoção de novas formas de construção e ação social coletiva, conforme discutido por Loureiro (2004), no plano das estratégias para a conservação da biodiversidade associado às áreas protegidas, como é o caso de uma RESEX.

Com base nestes argumentos, este artigo reafirma o pressuposto que o ecoturismo pode representar uma alternativa possível para o desenvolvimento local, se os grupos humanos envolvidos forem percebidos como protagonistas no processo e, se 
os benefícios socioeconômicos gerados estiverem vinculados ao compromisso de conservação do patrimônio cultural e natural local, assim como a melhoria de qualidade de vida.

A partir da noção de ecoturismo problematizada até então, em sua associação às Unidades de Conservação ${ }^{9}$ (UCs), é importante lembrar que as áreas naturais protegidas legalmente, constituem "atrativos", tanto para quem vive nessas áreas como para quem as visita, em busca de lazer, contemplação da paisagem, fauna, flora e também vivência de elementos culturais (CEBALLOS-LASCURÁIN, 2002). Sendo assim, no Brasil, um país de megasociobiodiversidade, o ecoturismo tende a representar uma importante alternativa de desenvolvimento para essas áreas, de forte impacto no imaginário global, principalmente no caso amazônico.

Mas para que seja possível entender, especificamente, o contexto do ecoturismo nas RESEX, é importante destacar que estas constituem uma categoria de manejo de UCs concebida a partir das especificidades do próprio país, podendo ser considerada uma tipologia genuinamente brasileira. A formulação desta proposta foi resultante de um panorama histórico de degradação do modo de vida dito tradicional e das pressões, cada vez maiores, sobre a floresta tropical amazônica. E a noção inspiradora para as RESEX surgiu também em decorrência das reivindicações do Movimento Seringueiro (1980), pelo fim da colonização nas áreas dos seringais e, pela concessão destas áreas às populações locais, para que pudesse ser mantida a atividade extrativista, a exemplo do que já acontecia nas terras indígenas. Estas populações, sobretudo na Amazônia Ocidental, em particular no Acre, resistiram fortemente aos processos tradicionais de uso e de ocupação da região, que tendiam a expulsá-los do local onde viviam, por meio de uma organização de base sindical e dos empates ${ }^{10}$ (GONÇALVES, 2003).

A proposta de criação de Reservas Extrativistas na Amazônia, liderada pelos seringueiros, buscou então, conciliar desenvolvimento e proteção da natureza, em um contexto no qual "o seringueiro marca uma relação histórica e cultural com a floresta". (GONÇALVES, 2003, p.11). Sendo assim, a figura da RESEX surgiu como estratégia de apropriação dos recursos naturais e de afirmação de identidades, a partir da relação entre o interesse social e o ambiental. Sua legitimidade provém do fato de ter sido formulada e demandada pelas próprias populações da floresta, (organizadas em torno do Conselho Nacional dos Seringueiros) e de ter sido incorporada pelo poder público, conforme a inspiração inicial.

Segundo o Sistema Nacional de Unidades de Conservação da Natureza (SNUC), instituído pela Lei $n^{\circ}$ 9.985/2000 (BRASIL, 2000 e 2002), a RESEX é considerada uma área protegida utilizada por populações extrativistas tradicionais, cuja subsistência baseia -se no extrativismo e, complementarmente, na agricultura e na criação de animais de pequeno porte, e tem como objetivos básicos proteger os meios de vida e a cultura dessas populações, e assegurar o uso sustentável dos recursos naturais.

Apesar das potencialidades de desenvolvimento da RESEX, muitas críticas sobre o seu processo de consolidação são, até hoje, trazidas à reflexão, com base no argumento de que as iniciativas desenvolvidas para a melhoria de qualidade de vida e para a conservação da biodiversidade não estão ainda articuladas, efetivamente, com as demandas locais. Não obstante, um dos principais desafios, neste caso, é a integração das populações envolvidas aos processos de gestão dos recursos naturais e também à distribuição 
de benefícios, inclusive pela via do ecoturismo, de forma justa e equitativa. Para tanto, o entendimento sobre as RESEXs implica na percepção da complexidade do contexto em que estas se inserem, das transformações socioambientais em curso e dos possíveis efeitos da economia global em seu cotidiano.

\section{A experiência da Reserva Extrativista do Cazumbá-Iracema rumo ao Ecoturismo}

A Reserva Extrativista do Cazumbá-Iracema (RESEX CI) se localiza em Sena Madureira e Manuel Urbano, no Estado do Acre (Amazônia Ocidental), abrangendo a quase totalidade da micro-bacia do rio Caeté e parte do rio Macauã, tributários do rio laco, afluente do rio Purus (Figura 1). Sua formação vegetal é, predominantemente, de Floresta Ombrófila Aberta, integrando o Corredor Oeste da Amazônia, um dos sete corredores ecológicos propostos para o Brasil (BRASIL, 2007). Sua estrutura de gestão se fundamenta em dois instrumentos principais: um Conselho Deliberativo, criado em 2006, e um Plano de Manejo, oficializado em 2008, que regulamenta as ações propostas para o seu desenvolvimento social e econômico.

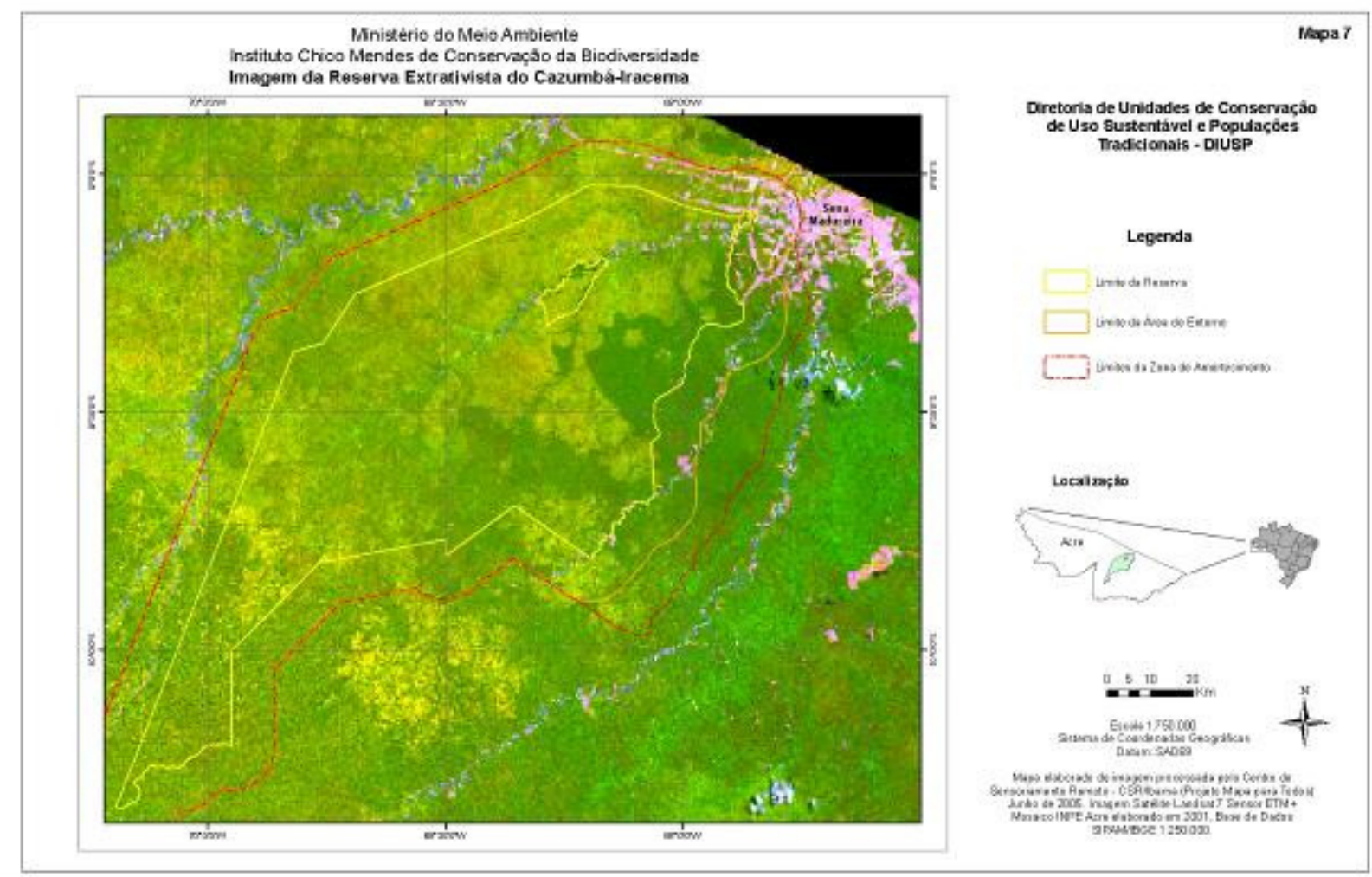

Figura 1: Imagem da RESEX do Cazumbá-Iracema.

Fonte: ICMBio, 2008 (apud MORAES, 2009, p.79).

Figure 1: Picture of the Extrativist Reserve Cazumbá-Iracema.

Source: ICMBio, 2008 (cited in MORAES, 2009, p.79). 
A RESEX Cl é habitada por famílias extrativistas, em sua maioria, migrantes nordestinos e seus descendentes, que foram para o Acre, incentivados pelo governo federal, durante os anos de valorização da borracha, no início do século XX. Sua área (750 mil ha) é dividida em cinco macro-regiões: Cazumbá, Médio Caeté, Alto Caeté, Jacareúba-Redenção e Riozinho-Cachoeira. A macro-região Cazumbá é a que possui o maior número de famílias, sendo que estas, em grande parte, residem em colocações ${ }^{11}$ dos seringais que deram origem à Reserva (BRASIL, 2007). Mas algumas ocupam uma área comunitária: o Núcleo do Cazumbá, foco deste artigo. O Núcleo do Cazumbá, através da sua organização formal, a Associação dos Seringueiros do Seringal Cazumbá (ASSC), foi o principal propulsor para a criação da RESEX Cl, em 2002. Originário dos conflitos fundiários em torno da posse dos seringais da região, o Núcleo do Cazumbá envolve 37 famílias e abriga toda a infraestrutura básica da RESEX (escola, igreja, posto de saúde e alojamento do ICMBio), sendo também o local onde algumas atividades tradicionais são realizadas, coletivamente, por homens e mulheres (BRASIL, 2007). A maioria dos moradores do Núcleo está no local desde o seu nascimento, vivendo quase que exclusivamente de atividades extrativistas (extração da borracha e castanha-do-Brasil), de agricultura familiar, da agropecuária, da caça e da pesca.

No plano do desenvolvimento turístico, em 2002, foi implantada no Núcleo, a primeira pousada da RESEX. E, desde então, se busca ali desenvolver o ecoturismo, de forma ainda embrionária, como uma possível alternativa econômica, sendo esta a única localidade da RESEX onde ocorre visitação. As visitas ocorrem, em geral, no período de inverno, quando há facilidade de deslocamento da cidade de Sena Madureira ao Núcleo do Cazumbá e, envolvem, prioritariamente, o público estudantil e populações da própria região, que buscam conhecer os projetos de desenvolvimento local na UC. No processo de visitação é realizada a divisão de tarefas entre os moradores, para atenderem aos visitantes. Dessa forma, os moradores envolvidos são remunerados pelo serviço prestado. Ocorre que, sendo a visita individual, a renda obtida tende a se concentrar em uma ou duas pessoas, o que gera desconforto entre os demais moradores, uma vez que os envolvidos na organização da visita são sempre os mesmos. Sendo assim, alguns moradores percebem que esse processo beneficia ainda poucas pessoas do local, o que tende a dificultar o desenvolvimento de iniciativas com o objetivo de geração de renda, valorização da cultura local e proteção da natureza, no plano coletivo.

Mas são ainda inúmeros os desafios a serem enfrentados no Núcleo para que o ecoturismo se torne, efetivamente, uma alternativa para o desenvolvimento local. E entre eles, um dos principais é exatamente compreender a perspectiva local sobre o processo, considerando o ponto de vista dos próprios moradores do Núcleo e dos interlocutores institucionais estratégicos envolvidos. Esta é a inspiração da pesquisa descrita neste artigo que buscou responder a duas questões principais: a) Qual a perspectiva presente para o desenvolvimento do ecoturismo? b) Como se projeta o ecoturismo no futuro? 


\section{Ecoturismo em uma perspectiva presente}

Os significados atribuídos, pela maioria dos moradores da RESEX, ao ecoturismo relacionam-se, principalmente, ao seu potencial de geração de renda, valorização da cultura local e contato com a natureza protegida. Neste sentido, sob a percepção local, o ecoturismo não se vincula apenas à conservação dos recursos naturais, mas também à valorização da cultura tradicional. Os moradores da RESEX CI reafirmam ainda ser o ecoturismo uma prática permitida nesta categoria de manejo, conforme prevê o SNUC, desde que esse se desenvolva de acordo com as diretrizes definidas pelos instrumentos de gestão da unidade de conservação. Os interlocutores institucionais pesquisados, por sua vez, vinculam o ecoturismo, principalmente, à conservação da biodiversidade, considerando a relevância do patrimônio natural e a demanda por uma prática de mínimo impacto. Estas leituras parecem estar em sintonia com alguns pressupostos relacionados ao conceito de ecoturismo discutido anteriormente, este entendido como uma prática que incentiva a proteção e a valorização do patrimônio natural e cultural.

Para além dessa visão consensual sobre ecoturismo, este é ainda interpretado pelos sujeitos da pesquisa como uma alternativa para o desenvolvimento local, e não apenas como meio para a geração de renda e/ou conservação da natureza. Pela leitura local, este é também interpretado como uma prática social, que tende a influenciar inúmeras relações entre visitantes e visitados. Esses pressupostos reafirmam a concepção de ecoturismo também como oportunidade de vivência de uma experiência de valor imaterial, afetivo, simbólico e espiritual, a partir do encontro de visitantes com a natureza e a cultura de um lugar, tendo a sociobiodiversidade como fator inspirador para o deslocamento.

O potencial de atrativos do Núcleo do Cazumbá reconhecido pela população local para o desenvolvimento do ecoturismo se sustenta na percepção e valorização do patrimônio natural e cultural, simultaneamente. Os "atrativos" reconhecidos pela própria população local são resumidos a seguir: Horta comunitária de plantas medicinais, Produção Agrícola Familiar (sobretudo a da farinha), Castanhal (castanha - do - Brasil), Criadouros de animais silvestres (queixada e jabuti), Unidade de Produção do Artesanato de borracha, Pousadas Comunitárias, Rio Caeté, Açudes, Estrada de seringa. Estes e outros atrativos identificados na pesquisa estão sistematizados, pedagogicamente, na Figura 2, a partir da vista aérea do Núcleo do Cazumbá. A partir da identificação desses elementos, é possível afirmar que o potencial reconhecido para o ecoturismo na RESEX tende a se vincular, de forma integrada, aos valores culturais e naturais, o que implica, por conseqüência, no reconhecimento da cultura tradicional e na necessidade de uso sustentável dos recursos naturais renováveis.

Mas os interlocutores institucionais pesquisados destacam também, como potencialidades e diferenciais para o desenvolvimento do ecoturismo no local, os aspectos marcantes e peculiares da história de conquista do próprio território acreano e o modo de vida tradicional. Neste caso, e considerando o impacto deste contexto no imaginário sobre a região, a experiência do turista que visita a RESEX poderia gerar uma reflexão cidadã sobre as dificuldades de vida na floresta e do manejo dos recursos naturais renováveis. Assim, o "encontro" entre esses sujeitos tende a inspirar um processo de transformação, subjetivação e reinvenção da realidade. Mas para um intercâmbio real entre "visitantes" e "visitados", Zaoual (2008) salienta que os turistas devem ser responsáveis e solidários em seus intercâmbios com outros mundos. Neste sentido, os moradores do Núcleo reconhecem também a importância, para o turista, em conhecer uma realidade diferente do seu 
Moraes, E.A.; Irving, M.A.

cotidiano, ao lidar com o estranhamento do "exótico" e se sensibilizar para a necessidade de desenvolvimento do destino visitado. E, sendo assim, o próprio intercâmbio e a vivência das experiências geradas na prática do ecoturismo tendem a ser potenciais benefícios resultantes do processo.

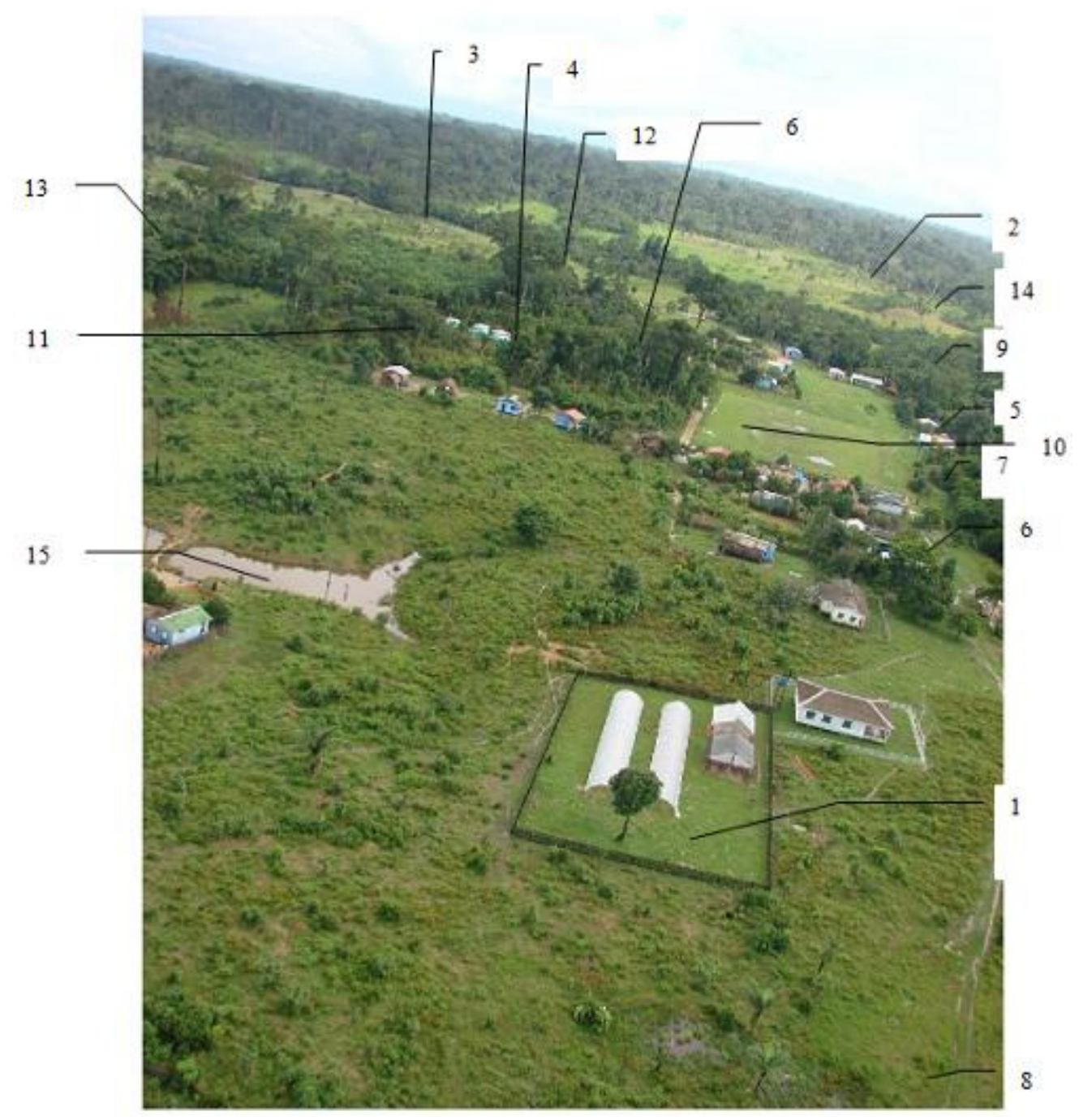

Legenda:
1. Horta de Plantas Medicinais
6. Unidade de Produção de Artesanato
11. Pousada
2. Casa de Farinha
7. Estrada de seringa
12. Criadouro de capivara
3. Castanhal
8. Rio Caeté
13. Trilhas
4. Criadouro de jabuti
9. Porto do Igara
5. Criadouro de queixada
10. Campo de futebol
14. Roçado
15. Açudes

Figura 2: Sistematização dos atrativos reconhecidos pelos moradores do Núcleo Cazumbá.

Fonte: Moraes (2009, p.122).

Figure 2: Systematization of appeal recognized by the residents of the Core Cazumbá.

Source: Moraes (2009, p.122). 
Quanto aos impactos indesejáveis reconhecidos com relação à chegada de visitantes pelos moradores locais, estes estão associados à questão do lixo, à alteração da dinâmica cotidiana, à possibilidade de marginalização das atividades tradicionais, ao surgimento do sentimento de "ganância" na população local, e, a um sentido perverso de homogeneização cultural, imposta pelos padrões capitalistas dominantes na prática do turismo convencional, como anteriormente discutido. Sendo assim, o reconhecimento das normas estabelecidas no Plano de Utilização ${ }^{12}$ da RESEX para o planejamento e a implementação do ecoturismo parece fundamental no processo, bem como a garantia de difusão clara das regras locais aos turistas, para que o intercâmbio de experiência entre turistas e anfitriões não influencie, negativamente, o modo de vida da população local.

Assim, para o Núcleo do Cazumbá, caracterizado por uma organização comunitária ainda incipiente, parece necessária a redefinição de prioridades e o fortalecimento de lideranças para que sejam empreendidas as ações previstas. Sob esta perspectiva, o planejamento e a gestão do ecoturismo, no futuro, devem ser pautados pelos compromissos de capacitação dos atores sociais locais, pelo fortalecimento da organização comunitária e pelo engajamento efetivo da população local no processo de tomada de decisão e controle social nas estratégias adotadas. Nesse sentido, esse processo deve se sustentar nas diversas manifestações culturais locais, e nos modos de se perceber, interpretar e organizar o ecoturismo, considerando-se, sobretudo, os valores imateriais, que integram o modo de vida do Núcleo. Os moradores locais apontam também como dificuldade para o processo, a carência de infraestrutura básica e turística e, a limitação de assistência técnica para a implementação e monitoramento de projetos em curso. Esses obstáculos parecem ainda difíceis de serem superados, se for considerado o apoio incipiente recebido dos órgãos oficiais, com relação às iniciativas de ecoturismo em UCs na Amazônia ${ }^{13}$.

Os interlocutores institucionais da pesquisa, por sua vez, apontam a distância dos centros urbanos, como a principal limitação para a implementação do ecoturismo, uma vez que essa prática, em localidades distantes, exige uma logística complexa e onerosa, como ocorre em outras experiências nas RESEX de Rondônia, Acre, Ceará, Bahia e Pará. Mas por serem recentes, as informações sobre experiências dessa natureza são limitadas e difusas, uma vez que, historicamente, as principais demandas de lazer e turismo estiveram direcionadas às unidades de conservação de proteção integral, como parques nacionais, que têm sido mais emblemáticos no debate sobre ecoturismo na Amazônia. Ainda na perspectiva institucional, a implementação e consolidação dos instrumentos de gestão da UC (Plano de Manejo, Plano de Utilização e Conselho Gestor) parece também essencial, para que se possa definir diretrizes que regulamentem essa prática, de acordo com as suas peculiaridades e demandas. Neste caso, apesar da RESEX Cl dispor desses instrumentos atualizados, estes não contemplam ainda um plano de ação e monitoramento do ecoturismo.

Moradores locais e interlocutores institucionais apontam ainda a necessidade de investimento financeiro, localmente, e pelo olhar institucional, se pode afirmar que os recursos financeiros públicos para a gestão destas áreas são ainda muito limitados, a não ser aqueles advindos de projetos de cooperação internacional. Sendo as- 
sim, parece evidente a necessidade de aporte financeiro do poder público para tais iniciativas, bem como para o próprio processo de efetivação da gestão da RESEX, de acordo com os seus objetivos de manejo e as especificidades de modos de vida das populações extrativistas.

\section{Ecoturismo na projeção de cenários futuros}

A partir da identificação das potencialidades e limitações para o desenvolvimento do ecoturismo no Núcleo do Cazumbá, algumas demandas locais são reafirmadas com este objetivo, na perspectiva futura, como sistematizado nas ações a seguir:

- Formação em associativismo e cooperativismo solidário;

- Especialização técnica em meios de hospedagem e alimentos e bebidas;

- Capacitação em operação logística de transportes e condução de visitantes (manejo de trilha, serviço de emergência médica);

- Realização de estudo de legislação ambiental aplicável as unidades de conservação;

- Capacitação em elaboração e gestão de projetos;

- Capacitação em informática e idiomas.

Evidentemente que este processo tende a envolver também a participação de agentes externos, pelas limitações de recursos humanos e financeiros. Weignand Júnior (2002) salienta também a importância estratégica de integração da população local com equipes técnicas especializadas para que se construa, conjuntamente, a capacidade em planejamento participativo e implementação de projetos. Nesse processo, o estabelecimento de parcerias pode representar um caminho para a concretização das demandas identificadas pelos moradores locais. Sendo assim, os interlocutores institucionais entrevistados reconhecem o seu papel como fundamental para a viabilização do ecoturismo no local.

A Secretaria do Meio Ambiente de Sena Madureira entende, por exemplo, ser a sua atuação potencialmente estratégica, devido à sua atribuição na definição do planejamento e zoneamento territorial do município, lhe competindo investir recursos públicos em infraestrutura básica e turística, no centro urbano e na zona rural. O ICMBio se reconhece também no exercício da função de articulação institucional da RESEX com potenciais parceiros, bem como no apoio e na orientação à população local sobre regulamentação, ordenamento e monitoramento do ecoturismo, de acordo com as normas que regem essa categoria de manejo de UC. E o WWF-BR se afirma como agente potencial para a capacitação da população local, a partir do seu envolvimento na realização de oficinas sobre as etapas metodológicas de planejamento e gestão do ecoturismo. O papel de agente facilitador na formação e capacitação técnica da população local em ecoturismo é reconhecido, da mesma forma, pela Secretaria de Espor- 
te, Turismo e Lazer do Estado do Acre, que vem incentivando iniciativas semelhantes, em outras localidades.

No plano nacional, o Grupo de Trabalho Amazônico e o Conselho Nacional dos Seringueiros percebem o seu papel como mediadores nas negociações entre a população local e os órgãos governamentais (esferas federal e estadual), a cooperação internacional e as ONGs transnacionais. Essas instituições reafirmam também o papel no fomento à discussão sobre projetos para as RESEX, nos conselhos dos órgãos relacionados ao desenvolvimento agrário do país, sendo esses, entendidos como espaços potenciais de negociação para investimentos em projetos de desenvolvimento local. O Conselho Nacional dos Seringueiros entende poder contribuir para o fortalecimento da organização comunitária. A Coordenação geral de RESEX e RDS (atualmente denominada de Gestão Socioambiental/ICMBio/MMA) se identifica como um agente governamental no suporte à elaboração de projetos de desenvolvimento local. E, a coordenação do PROECOTUR/PNE/MMA reconhece o seu papel potencial no apoio técnico à realização de projetos ecoturísticos junto às populações de UCs.

Algumas dessas instituições desenvolvem uma relação estreita com a RESEX $\mathrm{Cl}$ ou no cotidiano da gestão ou por terem participado de projetos conjuntos, o que tende a facilitar a sua articulação com os atores locais para a realização de iniciativas futuras, como a própria elaboração do projeto de ecoturismo da RESEX e, a captação de recursos financeiros para a sua implementação. Para tanto, a definição clara dos diferentes papéis destas instituições implica, fundamentalmente, no engajamento e no comprometimento das mesmas, de forma integrada e sistemática, no cumprimento de suas responsabilidades, para a concretização das decisões coletivas dirigidas ao desenvolvimento do ecoturismo na RESEX. Pelas razões expostas, a pesquisa parece indicar como estratégico o estabelecimento de parcerias e iniciativas colaborativas entre diferentes setores da sociedade civil em rede, para o desenvolvimento efetivo do ecoturismo. Neste sentido, os interlocutores institucionais entrevistados reconhecem a importância do diálogo, envolvendo propostas e estratégias comuns para o ecoturismo, para que este possa ser desenvolvido de forma integrada, intersetorial e interdisciplinar, considerando diferentes escalas de poder de decisão. Mas como já discutido, é fundamental que esta dinâmica seja inspirada, essencialmente, pela ótica dos interesses locais, com base no saber compartilhado, na experiência coletiva e no poder da participação social como via de desconstrução de uma cultura de subordinação para uma lógica de autonomia local.

Segundo a ótica institucional, outro desafio para o desenvolvimento do ecoturismo parece ser a melhoria da cadeia produtiva na RESEX. Para isso, Weignand Júnior (2002) salienta que a população local precisa ter aprimorada a sua capacidade de organização e gestão, com relação às ações coletivas e autogestionárias, ao nível do fortalecimento da associação ou da aplicação de recursos financeiros. Caso contrário, os financiamentos obtidos serão utilizados apenas para a sobrevivência da organização. Neste contexto, o fortalecimento de organização comunitária constitui um desafio central no processo projetual de ecoturismo na RESEX Cl. E apesar das boas intenções, desde a criação da RESEX, a capacidade interna de autogestão e co-gestão de ações que visem à melhoria da qualidade de vida, pelos próprios moradores, continua 
ainda incipiente, o que tende a dificultar a consolidação do processo.

Neste caso, a mobilização dos moradores locais, em conjunto com o ICMBIO com tal objetivo, parece ser um dos caminhos possíveis para se alcançar uma mudança de cenário. Porém, o processo de organização comunitária é longo, necessita de investimento relacional permanente e flexibilidade no planejamento das ações em curso, para a sua efetivação e controle social. É neste sentido que a participação dos moradores do Núcleo do Cazumbá em todo o processo de planejamento, implementação, monitoramento e avaliação do ecoturismo é reafirmada pelos interlocutores institucionais da pesquisa como um diferencial, neste caso estudado. Mas ainda assim, Weignand Júnior (2002, p.34) enfatiza que, "as populações locais necessitam de apoio contínuo para aprenderem como implementar projetos, que viabilizem o alcance dos objetivos propostos e a participação ampla dos envolvidos". Esse autor destaca ainda a importância da organização no período de pós-implementação dessas iniciativas, para o reconhecimento dos méritos, das mudanças positivas, e da necessidade de aperfeiçoamento das práticas em curso, pela própria população local, para que novos resultados possam ser alcançados com a garantia de consolidação daqueles já alcançados com êxito. Para tal, de acordo com os interlocutores institucionais, as lideranças envolvidas devem ter capacidade e sensibilidade para perceber e aceitar as limitações e as potencialidades locais, com relação às novas experiências motivadas pelo desenvolvimento ecoturístico. Nesse processo, as equipes técnicas externas em apoio aos projetos devem também ser flexíveis na execução de determinadas ações previstas e acordadas e estar habilitadas a promover estratégias de participação social e empoderamento da população envolvida, bem como a definir, precisamente, e, conjuntamente com os moradores do Núcleo, os indicadores de avaliação de processo. $\mathrm{O}$ engajamento da população local, por sua vez, é fundamental, sobretudo nas decisões a serem tomadas e na definição de prioridades, segundo os seus códigos culturais e visões de mundo.

Os moradores da RESEX e os interlocutores institucionais pesquisados expressam também uma clara preocupação com a intervenção do empresariado no processo e, o risco de terceirização de serviços nas iniciativas de ecoturismo, uma vez que, nesses moldes, muito provavelmente pouco (ou nada) seria investido na economia local. Isto porque o turismo que gira em torno de megaprojetos de capital (como os resorts e suas derivações) tende a fortalecer as economias dominantes globais e a excluir do processo as camadas sociais menos favorecidas, como é o caso das populações extrativistas na Amazônia.

Também por esta razão, é importante se pensar em instrumentos eficientes para assegurar o protagonismo da população local para que suas próprias demandas sejam consideradas. Para tanto, alguns interlocutores institucionais percebem ser fundamental que as ações para o ecoturismo sejam discutidas e aprovadas, formalmente, pelo Conselho Deliberativo da RESEX e pelos moradores envolvidos diretamente nas iniciativas em andamento. Por este motivo, parece ser importante que se avalie, também, a representatividade e a qualidade de interlocução das populações locais no âmbito do próprio Conselho Deliberativo da RESEX CI. Tal interpretação expressa ainda a necessidade, no futuro, de formação e/ou consolidação de uma câmara técnica 
de ecoturismo para a discussão de questões específicas sobre essa prática no Núcleo do Cazumbá. Além disso, é importante que as iniciativas propostas sejam discutidas no âmbito do Conselho Estadual de Turismo, para que se possa assegurar ações dirigidas à resolução dos problemas identificados, uma prerrogativa essencial para a formulação e a implementação de políticas públicas de turismo na região, em longo prazo. Neste intento, os interlocutores institucionais reconhecem ainda como estratégico que os agentes envolvidos conheçam os compromissos de políticas públicas de proteção da natureza e de turismo, para que possam compreender a sua articulação com as demandas de desenvolvimento local.

Diante destas percepções e significados por ora convergentes, por outras divergentes, mesmo sendo o ecoturismo considerado como uma alternativa possível para o desenvolvimento na RESEX do Cazumbá-Iracema, este não representa ainda uma alternativa de fácil implementação e, muito menos, deve ser entendido como a solução mágica para os problemas enfrentados pela população local. E para que a transformação esperada se efetive, em nível local, com a expectativa de novos horizontes para a população envolvida, é ainda necessário que se avance no sentido de consolidação do ecoturismo, com base no compromisso do uso racional dos recursos naturais renováveis, na compreensão do protagonismo social e no reconhecimento do valor das peculiaridades regionais como diferencial.

\section{Considerações finais}

Do luxo dos "hotéis de selva" à simplicidade dos modos de vida dos povos da floresta até aos banhos de rio e igarapé, o ecoturismo na Amazônia brasileira se desenvolve em meio a contrastes de todos os tipos. Mas a floresta e os modos de vida local deslumbram turistas e tendem a representar importantes inspirações para a geração de alternativas econômicas para as populações que ali residem. Mas apesar desta potencialidade, uma questão merece reflexão: Quem se beneficia efetivamente com o ecoturismo na região? É nesta direção que movimentos sociais e interlocutores da gestão pública discutem alternativas sustentáveis para a subsistência das populações amazônicas, que vivem à margem das políticas públicas. E, sob este prisma, o ecoturismo passa a ser considerado como uma possível alternativa para o desenvolvimento local associado às UCs, sobretudo naquelas que envolvem populações tradicionais.

O estudo sobre a interpretação dos moradores do Núcleo do Cazumbá e dos interlocutores institucionais estratégicos a respeito do processo revela um contexto complexo e associado a inúmeros desafios futuros para o planejamento e gestão dessa prática na RESEX do Cazumbá-Iracema, a médio e longo prazos.

$\mathrm{E}$, no contexto de pesquisa, reafirma-se também a premissa que o ecoturismo sob a ótica local, não se vincula apenas ao compromisso de conservação dos recursos naturais, mas também à compreensão de que a proteção da biodiversidade está condicionada à valorização da cultura e do modo de vida tradicional. Pela via do ecoturismo, a experiência de quem visita a RESEX pode até mesmo trazer à reflexão a compreensão das dificuldades de vida na floresta, resgatando e reinventando as rela- 
ções estabelecidas por e entre homem e natureza.

Não se pode deixar de mencionar que, as unidades de conservação associadas ao modo de vida tradicional, como é o caso das RESEXs, são destinos singulares para uma prática alternativa às formas convencionais de turismo, que, na maioria dos casos, buscam resultados imediatos sem o compromisso com as culturas locais ou com a conservação da biodiversidade e que, portanto, tendem a se tornar insustentáveis no decorrer do tempo, ocasionando desagregação da cultura local e impactos indesejáveis ao patrimônio natural. Mas, neste caso, não bastam apenas sinalizações com mensagens do tipo: "sejam bem vindos!". Diversos obstáculos precisam ainda ser transpostos para o desenvolvimento do ecoturismo na RESEX Cl, como o equacionamento dos problemas de carência de infraestrutura básica e turística, da mobilização comunitária deficiente, e, da limitação de assistência técnica para o acompanhamento, implementação e monitoramento de projetos com este objetivo. Esses obstáculos tornam-se difíceis de serem superados, principalmente, quando se considera o apoio ainda insuficiente dos órgãos governamentais, especificamente no caso daquele dirigido às iniciativas de ecoturismo em UCs na Amazônia brasileira.

Mas ainda assim, a pesquisa tende a indicar que o protagonismo das populações locais na configuração do ecoturismo constitui a garantia para a transformação de sua realidade, o que depende diretamente de se ter como referência quem são os atores envolvidos e do engajamento e articulação social para a construção de seus próprios discursos e práticas ${ }^{14}$.

\section{Referências bibliográficas}

ALEGRETTI, M.H. Reservas Extrativistas: Parâmetros para uma política de desenvolvimento sustentável na Amazônia. In: ANDERSON, A. et al. 0 destino da floresta: reservas extrativistas e desenvolvimento sustentável na Amazônia. Rio de Janeiro: Relume-Dumará, 1994. p. 17-47.

ALVES-MAZZOTTI, A.J.; GEWANDSZNAJDER, F. O método nas ciências naturais e sociais. Pesquisa Quantitativa e Qualitativa. São Paulo: Pioneira Thompson Learning, $2^{\text {a }}$ ed., 2004.

BARDIN, I. Análise de conteúdo. Lisboa: Edições Setenta, 1994.

BUARQUE, S.C. Construindo o desenvolvimento local sustentável - Metodologia de planejamento. Rio de Janeiro: Garamond, 2002.

BRASIL, Ministério da Fazenda. Economia brasileira em perspectiva. 14a Edição Especial. Brasília: Ministério da Fazenda, 2012.

BRASIL. Plano de Manejo da Reserva Extrativista do Cazumbá-Iracema. MMA, ICMBIO, DIUSP, Superintendência do IBAMA no Estado do Acre. Sena Madureira - AC, dezembro de 2007.

BRASIL. Decreto n. 4.340, de 22 de agosto de 2002. Sistema Nacional de Unidades de Conservação da Natureza - SNUC. 4ª Edição. Brasília: MMA/SBF, 2004. 
BRASIL. Lei n. 9.985, de 18 de julho de 2000. Sistema Nacional de Unidades de Conservação da Natureza - SNUC. 4ª Edição. Brasília: MMA/SBF, 2000.

BRASIL. Diretrizes para uma Política Nacional de Ecoturismo. Brasília: EMBRATUR, 1994.

CEBALLOS-LASCURÁIN, H. Introdução: o ecoturismo como fenômeno mundial. In: LINDBERG, K.; HAWKINS, D. E. (Orgs.). Ecoturismo: um guia para planejamento e gestão. São Paulo: Ed. Senac, 2002, p.23-29.

DIEGUES, A.C. O mito moderno da natureza intocada. São Paulo: HUCITEC, 1996.

DIEGUES, A.C. As áreas naturais protegidas, o turismo e as populações tradicionais. In: SERRANO, C., BRUHNS, H. (Orgs.). Viagens à natureza: Turismo, cultura e ambiente. Campinas, SP: Papirus, 1997. (Coleção Turismo), p. 85-101.

FENNEL, D. Ecoturismo, uma introdução. São Paulo: Contexto, 2002.

GONÇALVES, C.W.P. Geografando nos varadouros do mundo: da territorialidade seringalista (o seringal) à territorialidade seringueira (a Reserva Extrativista). Brasília: IBAMA, 2003.

IBGE Instituto Brasileiro de Geografia e Estatística. Indicadores de Desenvolvimento Sustentável Brasil 2008. Estudos e Pesquisas Informação Geográfica, número 5. Rio de Janeiro: IBGE, 2008.

IRVING, M.A. Ecoturismo em Áreas Protegidas: Da Natureza ao Fenômeno Social. In: COSTA, N.M.C; NEIMAN, Z.; COSTA, V.C. Pelas trilhas do Ecoturismo. São Carlos: Editora RIMA, 2008, p.3-15.

IRVING, M.A. Áreas Protegidas de fronteira e turismo sustentável na Amazônia: entre o surrealismo e a invenção. Revista de Desenvolvimento Econômico. Salvador, Ano VIII, No 13, 2006.

IRVING, M.A. Áreas Protegidas e Inclusão Social: Construindo novos significados. Rio de Janeiro: Editora Aquarius, 2006.

LOUREIRO, C.F. Educar, participar e transformar em educação ambiental. Revista Brasileira de Educação Ambiental. Brasília, Ano I, No 0, 2004, p. 13-20.

MORAES, E.A. Encontro na Floresta: Interpretando o Ecoturismo sob a ótica local na Reserva Extrativista do Cazumbá-Iracema (Acre-Brasil). Rio de Janeiro: UFRJ. Programa Eicos - Mestrado, 2009.

MORAES, E.A.; IRVING, M.A. Ecoturismo em reservas extrativistas na Amazônia: avanços e desafios. II Encontro de Ecoturismo em Unidade de Conservação e I Congresso Nacional de Ecoturismo, 2007. Itatiaia. Anais... Itatiaia: Physis, 2007 (CD ROOM).

MURRIETA, J.R.; RUEDA, R.P. Gestão das Reservas Extrativistas. In: UICN, Reservas Extrativistas. Gland, Suíça e Cambridge, Reino Unido. SADAG, Bellegarde-surValserien. France, 1995.

PIRES, P.S. Dimensões do Ecoturismo: uma investigação conceitual. São Paulo: Editora SENAC São Paulo, 2002. 
PRADO, R. Tensão no Paraíso: Aspectos da Intensificação do Turismo na llha Grande. 7ª Edição. Caderno Virtual de Turismo - LTDS/COPPE/UFRJ (Março, 2003).

STEIL, C. Antropologia do Turismo: comunidade e desterritorialização. In: PERALTA, E.; ANICO, M. (Org.). Patrimônios e Identidades. Ficções contemporâneas. Oeiras: Celta Editora, 2006, p. 163-170.

WEFORUM. The Global Competitiveness Report 2010-2011. World Economic Forum, 2010, p. 32. Disponível em http://www3.weforum.org/docs/ WEF GlobalCompetitivenessReport 2010-11.pdf. Acesso em 01 de outubro de 2012.

WEIGNAND-JR, R. Por que as atuais linhas de financiamento limitam o desenvolvimento comunitário sustentável em reservas extrativistas. Revista Participe. Porto Alegre, 2002.

ZAOUAL, H. Do turismo de massa ao turismo situado: quais as transições? Caderno Virtual de Turismo. Rio de Janeiro: Vol. 8, N², 2008.

\begin{abstract}
Notas
${ }^{1}$ Disponível em http://360graus.terra.com.br/ecoturismo/default.asp? did=27343\&action=reportagem.

${ }^{2}$ Diegues (1996) explica que o mito supõe a incompatibilidade entre as ações de quaisquer grupos humanos e a conservação da natureza.

${ }^{3}$ Esta técnica consiste em identificar uns poucos sujeitos e pedir-lhes que indiquem outros, os quais, por sua vez, indicarão outros e assim sucessivamente, até que se atinja o ponto de redundância.

${ }^{4}$ Em 2011, a RESEX Cl passou a se vincular a Coordenação Regional de Porto Velho.

${ }^{5} \mathrm{Em}$ 2010, a DIUSP passou a ser denominada de Coordenação Geral de Gestão Socioambiental.

${ }^{6}$ Época de publicação do Relatório Nosso Futuro Comum, em que o movimento ambientalista conquista muitos adeptos a favor da proteção da natureza e a questão ambiental passa a fazer parte das preocupações de diferentes instâncias políticas e da agenda dos grandes temas estratégicos mundiais.

${ }^{7} \mathrm{~A}$ concepção predominante de turismo influenciada pela dinâmica capitalista, principalmente até a década de 1970 (com rebatimentos até a atualidade, centrada na lógica do mercado), se baseia na compra e venda de produtos e serviços padronizados, com forte apelo comercial, privilegiando o lucro e a escala de massa, tendo como consequências inúmeros impactos indesejáveis com relação à autenticidade dos lugares turísticos e aos processos de proteção da natureza.
\end{abstract}

${ }^{8}$ Adotou-se a perspectiva de Buarque (2002) que entende desenvolvimento local como um longo processo endógeno de mudança, que leva ao dinamismo econômico e à melhoria de vida de populações de pequenas unidades territoriais. Essas mudanças são, sobretudo, qualitativas para que uma determinada comunidade possa autogerir-se, sendo estimulado e fortalecido o seu potencial social, cultural, econômico, ambiental e político. Nesse caso, os recursos endógenos são entendidos sempre como ponto de partida e nunca 
como ponto de chegada.

${ }^{9}$ Espaço territorial e seus recursos ambientais, incluindo as águas jurisdicionais, com características naturais relevantes, legalmente instituído pelo poder público, com objetivos de conservação e limites definidos, sob regime especial de administração do qual aplicam garantias adequadas de proteção (BRASIL, 2000).

${ }^{10}$ Os empates eram manifestações das famílias seringueiras que se reuniam rumo à floresta, para tentar conter ações de devastação da natureza e garantir a suspensão da atividade predatória.

${ }^{11}$ Unidades habitacionais definidas pelo número e extensão das estradas de seringa, estabelecidas em função da localização das seringueiras.

${ }^{12} \mathrm{O}$ Plano de Utilização é o documento de base do Plano de Manejo, consistindo no conjunto de regras internas construídas, definidas e compactuadas pela população da UC, quanto às atividades tradicionalmente praticadas, o manejo dos recursos naturais renováveis, o uso e ocupação da terra e a conservação ambiental, considerando-se a legislação vigente.

${ }^{13}$ Os dados obtidos nos levantamentos de campo indicam que há uma sensação de distanciamento do poder público com relação às ações desenvolvidas no local. Isto ocorre apesar do desenvolvimento, na década de 2000, do PROECOTUR. Apesar de elevados investimentos deste Programa, pouco se reconhece de seus efeitos em benefício dos interesses locais.

${ }^{14}$ Este artigo é derivado de dissertação de mestrado.

Edilaine Albertino de Moraes: Universidade Federal de Juiz de Fora, Juiz de Fora, MG, Brasil.

Email: edilainerumos@yahoo.com.br

Link para o currículo Lattes: http://lattes.cnpq.br/5450933897214464

Marta de Azevedo Irving: Universidade Federal do Rio de Janeiro, Rio de Janeiro, RJ, Brasil.

Email: marta.irving@mls.com.br

Link para o currículo Lattes: http://lattes.cnpq.br/1912229324377473

Data de submissão: 1ํ de maio de 2013

Data de recebimento de correções: 15 de maio de 2013

Data do aceite: 08 de junho de 2013

Avaliado anonimamente 


\title{
Empreendedorismo sustentável em regiões turísticas de Goiás
}

\author{
Sustainable entrepreneurship in tourist regions of Goiás (Brazil) \\ Thaynara Santiago Pereira, Cândido Borges
}

\begin{abstract}
RESUMO
O objetivo deste artigo é compreender o processo de criação de empresas por empreendedores que exploram o nicho da sustentabilidade e os principais desafios que eles encontram nesse processo. $O$ artigo apresenta os resultados de uma pesquisa qualitativa e exploratória em que cinco casos de empresas localizadas em duas regiões turísticas de Goiás - Pirenópolis e Chapada dos Veadeiros - foram analisados. Como quadro de análise foi utilizado um modelo que estrutura o processo de criação em quatro etapas: iniciação, preparação, lançamento e consolidação. Os dados primários foram coletados por meio de entrevistas com os empreendedores. Os resultados obtidos apontam a ausência de motivação exclusivamente financeira dos empreendedores, a ausência de práticas estruturadas de planejamento e a adoção de práticas de responsabilidade ambiental acompanhada, em alguns casos, de responsabilidade social. As principais dificuldades encontradas pelos empreendedores na criação da empresa foram agrupadas em três categorias: dificuldades com serviços ou políticas públicas, dificuldades relacionadas ao processo logístico ou de produção, dificuldades relacionadas à falta de planejamento. O presente artigo contribui para facilitar e estimular a ação dos empreendedores que pretendem criar negócios sustentáveis, assim como os gestores públicos, responsáveis por políticas de apoio a esse tipo de empreendedorismo.
\end{abstract}

PALAVRAS-CHAVE: Empreendedorismo Sustentável; Turismo; Processo de Criação de Empresas.

\begin{abstract}
The aim of this article is to understand the process of business creation by entrepreneurs who explore the sustainability niche and to identify the main challenges they face in this process. The article presents the results of a qualitative study in which five cases of companies located in two tourist regions of Goiás - Pirenópolis and Chapada dos Veadeiros - were analysed. A model which structures the creation process in four stages (initiation, preparation, launch and consolidation) was used as framework for this analysis. The primary data were collected through interviews with the entrepreneurs. The results obtained indicate a lack of exclusively financial motivation on the part of the entrepreneurs, the absence of structured planning practices and the adoption of environmentally responsible together with, in some cases, socially responsible practices. The main difficulties which the entrepreneurs encountered in the creation of the companies were grouped into three categories: difficulties with public services, difficulties related to the logistical or production processes and difficulties related to the lack of planning. The present article seeks to facilitate and to stimulate the activities of entrepreneurs who aim to create sustainable businesses as well as the public officials responsible for implementing policies to support this type of entrepreneurship.
\end{abstract}

KEYWORDS: Sustainable Entrepreneurship; Tourism; New Venture Creation Process.

Página 758 Revista Brasileira de Ecoturismo, São Paulo, v.6, n.3, ago/out 2013, pp.758-777.

Sociedade Brasileira de Ecoturismo. Rua Dona Ana, 138, Vila Mariana, São Paulo, SP - Brasil. E-mail: rbecotur@sbecotur.org.br; Tel. (55-II) 99196-7685 


\section{Introdução}

O surgimento do tema sustentabilidade relacionado ao desenvolvimento econômico ocorreu ao longo do século XX, a partir da percepção de que os recursos despendidos no intensivo padrão de produção e consumo eram finitos e que não subsistiriam (NASCIMENTO, 2012). Alguns dos grandes marcos que simbolizam essa percepção são a Conferência de Estocolmo, em 1972, o relatório Brundtland, em 1987 e a Eco-92 (MORETTO; GIACCHINI, 2005; NASCIMENTO, 2012). Essas discussões atingem o mundo corporativo, se concretizando em temas como gestão ambiental e responsabilidade social, e o desenvolvimento sustentável passa a ser abordado não como um problema, mas como algo possível e necessário (MELO; COHEN, 2009).

Dessa forma, uma nova lógica de produção vem sendo institucionalizada e as organizações passam a inovar atendendo às três dimensões da sustentabilidade social, ambiental e econômica (BARBIERI et al., 2010). Com base nessas dimensões, que constituem o modelo Triple Bottom Line (ELKINGTON, 1998), organizações sustentáveis são aquelas que conseguem atuar perduravelmente, se relacionando bem com a sociedade e minimizando riscos (SCHARF, 2004).

Dentro desse contexto, a literatura define como empreendedorismo sustentável a criação de organizações baseadas nesse tripé (social, ambiental e econômico), ou ainda a criação de empresas que simplesmente explorem o nicho da sustentabilidade (BORGES et al., 2011).

No que tange ao empreendedorismo, no Brasil, há ainda poucos estudos deste tema voltados à área de turismo (TEIXEIRA, 2012). Se essa temática de uma forma geral já apresenta limites na literatura, estes são ainda maiores quando inserimos o tema sustentabilidade na discussão. Frente a esta lacuna, este artigo tem como objetivo compreender como os empreendedores que exploram o nicho da sustentabilidade realizam as principais atividades do processo de criação de empresas e identificar quais são os principais desafios desses empreendedores nesse processo.

A maior compreensão das atividades que os empreendedores realizam no processo de criação de novas empresas sustentáveis, incluindo seus obstáculos, pode ajudar os futuros empreendedores a trilhar com maior facilidade o caminho na criação de negócios que exploram o nicho da sustentabilidade. Pode ainda auxiliar os gestores públicos e as pessoas e organizações que apoiam o empreendedorismo a melhor formular e implementar políticas de apoio a empreendedorismo sustentável. Estimular a geração de iniciativas empreendedoras sustentáveis pode contribuir para que um número cada vez maior de organizações atue de forma efetivamente sustentável, onde o tripé social-econômico-ambiental seja respeitado.

Antes de apresentar a metodologia utilizada na pesquisa, será apresentado, na próxima seção, o referencial teórico da pesquisa. Na seção seguinte serão apresentados os resultados da análise. E na última seção, a conclusão do trabalho, com suas principais contribuições e sugestões para futuras pesquisas. 


\section{Fundamentação teórica}

\section{Empreendedorismo}

O empreendedorismo é um processo que passa pela identificação, avaliação e exploração de uma oportunidade de ação (SHANE; VENKATARAMAN, 2000). Ele envolve a capacidade humana de se favorecer moldando as condições do ambiente através de um processo de criação de uma nova realidade (COSTA, 2008).

Melo Meto e Froes (2002) ressaltam o papel do empreendedorismo no desenvolvimento local. Para estes autores, nos moldes atuais, existem quatro correntes de estudos do empreendedorismo, e uma delas se preocupa com as questões do desenvolvimento local. Ainda segundo Melo e Froes (2002), o empreendedorismo designa os estudos relativos ao universo de atuação dos empreendedores, seus perfis, sistemas de atividades e origens.

O empreendedor é o principal agente do empreendedorismo. Para Filion (1999), o empreendedor é uma pessoa criativa, que objetiva a inovação e possui um alto nível de consciência ambiental da qual se utiliza para detectar oportunidades de negócio. De acordo com Schaltegger (2002), o empreendedor pode ser interpretado como aquele que toma a iniciativa para "construir pontes", como um catalisador que reúne dinheiro, pessoas, ideias e recursos.

No que diz respeito aos estudos relativos a empreendedorismo e empreendedores, percebe-se na atualidade uma segmentação do tema, de forma a facilitar sua interpretação. Já se fala em empreendedorismo tecnológico (SHANE, 2001), empreendedorismo cultural (DEHEINZELIN, 2006; LIMEIRA, 2008), empreendedorismo por mulheres (MACHADO et al., 2003), empreendedorismo social (MAIR; MARTI, 2006) e empreendedorismo ambiental ou ecoempreendedorismo (SCHALTEGGER, 2002; DIXON; CLIFFORD, 2007), sendo que estes dois últimos podem ser considerados precursores e elementos constituintes do emergente empreendedorismo sustentável (HOCKERTS; WUSTENHAGEN, 2010; PARRISH, 2007).

O empreendedorismo sustentável, segundo Boszczowski e Teixeira (2009), surge por meio de estudos envolvendo meio ambiente, responsabilidade social e negócios, como resposta a uma necessidade das empresas de mudarem suas práticas sociais e ambientais. Para as autoras, o empreendedorismo sustentável pode ser entendido como uma função da produção, de forma que "seu principal objetivo seria produzir bens e serviços que atuem nas soluções dos problemas da sociedade" (BOSZCZOWSKI; TEIXEIRA, 2009, p.11). Boszczowski e Teixeira (2009) afirmam ainda que as oportunidades de negócios sustentáveis podem ser caracterizadas como as oportunidades que proporcionam aos empreendedores possíveis soluções para falhas de mercado relevantes ao meio ambiente, aumentando o bem estar social e promovendo o desenvolvimento sustentável social. Essa visão está de acordo com o conceito de Shepherd e Patzelt (2011, p.142, tradução nossa):

Empreendedorismo sustentável é focado na preservação da natureza, no suporte à vida e à comunidade, em busca de perceber oportunida- 
des para trazer à existência futura produtos, processos e serviços para o ganho, onde o ganho é amplamente interpretado de forma a incluir os ganhos econômicos e não econômicos para os indivíduos, a economia e a sociedade.

Young e Tilley (2006), em congruência com o modelo Triple Bottom Line (ELKINGTON, 1998), afirmam que o empreendedorismo sustentável engloba três dimensões do empreendedorismo - econômica, social e ambiental. Pimentel, Reinaldo e Oliveira (2010) resumem as três dimensões preconizadas por Young e Tilley (2006) da seguinte forma (Quadro 1):

Quadro 1: Dimensões do empreendedorismo sustentável.

Chart 1: Dimensions of sustainable entrepreneurship.

\begin{tabular}{|l|l|}
\hline Dimensão do Empreendedorismo econômico & $\begin{array}{l}\text { empreender com o objetivo de desenvolver uma ativi- } \\
\text { dade que gere lucro. Refere-se à capacidade da em- } \\
\text { presa de manter-se viva, de ser um negócio autossus- } \\
\text { tentável. }\end{array}$ \\
\hline Dimensão do Empreendedorismo Social & $\begin{array}{l}\text { empreender com o objetivo de gerar valores sociais e } \\
\text { culturais de maneira criativa e inovadora. }\end{array}$ \\
\hline $\begin{array}{l}\text { Dimensão do Empreendedorismo Ecológico ou Am- } \\
\text { biental }\end{array}$ & $\begin{array}{l}\text { empreender utilizando estratégias de negócio proati- } \\
\text { vas e ecologicamente orientadas, redefinindo sua } \\
\text { cultura e suas relações sociais. }\end{array}$ \\
\hline
\end{tabular}

Fonte: Adaptado de Pimentel, Reinaldo e Oliveira (2010, p. 7-8).

Source: Adapted from Pimentel, Reinaldo e Oliveira (2010, p. 7-8).

Para Borges et al. (2011) o empreendedorismo sustentável também tem ligação com o empreendedorismo social e o ambiental. E essa ideia é reforçada através da sugestão de uma tipologia para o empreendedorismo sustentável, de acordo com o Quadro 2 a seguir:

Quadro 2: Tipos de empreendedorismo sustentável.

Chart 2: Types of sustainable entrepreneurship.

\begin{tabular}{|c|c|}
\hline Indicador & Tipo \\
\hline Nicho da sustentabilidade explorado & $\begin{array}{c}\text { Negócio ambiental } \\
\text { Negócio social }\end{array}$ \\
\hline Papel da sustentabilidade & $\begin{array}{c}\text { Sustentabilidade como meio } \\
\text { Sustentabilidade como objetivo }\end{array}$ \\
\hline Uso da responsabilidade social empresarial & $\begin{array}{c}\text { Com responsabilidade social empresarial } \\
\text { Sem responsabilidade social empresarial }\end{array}$ \\
\hline
\end{tabular}

Fonte: Borges et al. (2011, p. 5).

Source: Borges et al. (2011, p. 5).

De acordo com o quadro, o empreendedorismo sustentável pode abranger diversos tipos, variando em função de determinados indicadores. O primeiro indicador é o nicho de sustentabilidade explorado, que pode determinar se o negócio é um tipo de 
negócio ambiental ou social. Segundo os autores, o negócio ambiental está relacionado a produtos, serviços e processos que atuam no sentido de internalizar, minimizar ou se antecipar às externalidades ambientais, e podem ser divididos em quatro categorias: a) produtos ecoeficientes; b) turismo e lazer na natureza. c) agricultura orgânica e extrativismo; e d) reciclagem e reutilização. O negócio social, para Borges et al. (2011), aborda produtos e serviços que melhorem as condições e a qualidade de vida de grupos socialmente desfavorecidos.

O segundo indicador relaciona-se ao papel da sustentabilidade, ou seja, se as ações sustentáveis foram realizadas como um objetivo ou como um meio:

Para uns, o objetivo principal com o empreendimento é o lucro, e a exploração de um negócio social ou ambiental é o meio utilizado para isso. Para outros, o objetivo é colaborar para o desenvolvimento sustentável, e o lucro proporcionado pelo negócio é apenas um meio de manter uma empresa e um estilo de vida compatível com os valores da sustentabilidade (BORGES et al., 2011, p.7).

O terceiro indicador diz respeito ao uso ou não da responsabilidade social empresarial, que resume a combinação dos termos responsabilidade social e ambiental (BORGES et al., 2011).

\section{O processo de criação de empresas}

O processo de criação de empresas, segundo Hisrich, Peters e Shepherd (2009), é o processo de buscar um novo empreendimento, seja introduzir novos produtos em mercados existentes, de produtos existentes em novos mercados, e/ou a criação de uma nova organização.

Alguns autores do campo do empreendedorismo, para explicar o complexo e dinâmico processo de criação de uma nova empresa, utilizam-se de modelos, que dividem este processo em etapas, facilitando a compreensão e estudo do fenômeno (BORGES; FILION; SIMARD, 2008). Há, portanto, diferentes modelos que sintetizam as etapas e atividades que se encaixam nesse processo de criação. Um dos modelos propostos é o modelo de Hisrich, Peters e Shepherd (2009).

Para Hisrich, Peters e Shepherd (2009, p.31), "um empreendedor precisa encontrar, avaliar e desenvolver uma oportunidade, superando as forças que resistem à criação de algo novo". Além disso, Hisrich, Peters e Shepherd (2009) afirmam ainda que, embora as fases do processo de criação de uma empresa ocorram progressivamente, nenhuma é tratada isoladamente ou está totalmente concluída antes de ocorrer o trabalho nas outras fases.

Borges, Filion e Simard (2008) também propuseram um modelo, baseado em quatro etapas, com o intuito de desenvolver uma estrutura para facilitar o entendimen- 
to do processo de criação. Assim, combinando as etapas e atividades mais citadas na literatura, os autores elaboraram o seguinte modelo de análise, aqui apresentado em sua forma simplificada (Quadro 3):

Quadro 3: Etapas e atividades do processo de criação.

Chart 3: Steps and activities of the creation process.

\begin{tabular}{|c|c|c|c|c|}
\hline Etapas & Iniciação & Preparação & Lançamento & Consolidação \\
\hline $\begin{array}{l}\text { Ativi- } \\
\text { dades }\end{array}$ & $\begin{array}{l}\text { Identificação da opor- } \\
\text { tunidade de negócio. } \\
\text { Reflexão e desenvolvi- } \\
\text { mento da ideia de } \\
\text { negócio. } \\
\text { Decisão de criar a } \\
\text { empresa. }\end{array}$ & $\begin{array}{l}\text { Redação do plano de } \\
\text { negócios. } \\
\text { Mobilização de recur- } \\
\text { sos financeiros. } \\
\text { Constituição da equipe } \\
\text { empreendedora. } \\
\text { Constituição legal da } \\
\text { empresa. }\end{array}$ & $\begin{array}{l}\text { Instalação física e de } \\
\text { equipamentos } \\
\text { Desenvolvimento do } \\
\text { primeiro produto ou } \\
\text { serviço. } \\
\text { Contratação de cola- } \\
\text { boradores. } \\
\text { Comercialização e } \\
\text { venda. }\end{array}$ & $\begin{array}{l}\text { Novas rodadas de } \\
\text { financiamento. } \\
\text { Promoção e comer- } \\
\text { cialização. } \\
\text { Operação e produ- } \\
\text { ção. } \\
\text { Gestão da nova } \\
\text { empresa. } \\
\text { Alcance do ponto de } \\
\text { equilíbrio }\end{array}$ \\
\hline
\end{tabular}

Fonte: Adaptado de Borges, Filion e Simard (2008).

Source: Adapted from Borges, Filion e Simard (2008).

O modelo de Borges, Filion e Simard foi construído inicialmente para o empreendedorismo tradicional, mas já foi adaptado e utilizado com sucesso no estudo da criação de empreendimentos sociais por Onozato e Teixeira (2008). Dessa forma, ele apresenta potencial para ser utilizado e adaptado para o estudo de empresas sustentáveis.

\section{Método de pesquisa}

A pesquisa foi qualitativa e exploratória, com enfoque indutivo. A estratégia de pesquisa utilizada foi o estudo de casos múltiplos (YIN, 2005). O estudo de caso é uma das muitas maneiras de fazer pesquisa em ciências sociais e segundo Yin (2005) é uma investigação empírica que examina um fenômeno contemporâneo dentro do contexto da vida real, especialmente quando os limites entre este fenômeno e o contexto não estão claramente definidos. Nesta perspectiva, o estudo de caso de natureza qualitativa proporciona uma análise profunda acerca da natureza do objeto em questão - explicar como se desenvolve o processo de criação de empresas sustentáveis.

Dessa forma, foi feito um levantamento de possíveis casos de criação de empresas relacionadas ao empreendedorismo sustentável no estado de Goiás. Os empreendedores das organizações foram contatados por e-mail e telefone e aceitaram participar da pesquisa. Por motivos de confidencialidade, os nomes das organizações e dos empreendedores citados neste artigo são fictícios.

As cinco organizações selecionadas foram: Pousada Pirenópolis; Herbário; Empresa Alimentos Orgânicos; Santuário e Pousada Cavalcante. Em todos os casos o tipo de nicho de sustentabilidade explorado é o ambiental, sendo que a Pousada Pirenópolis, o 
Santuário e a Pousada Cavalcante estão classificados no grupo turismo e lazer na natureza e o Herbário e a Empresa Alimentos Orgânicos como agricultura orgânica e extrativismo. Em ambos os casos a sustentabilidade é concebida como um objetivo pelos empreendedores. No que diz respeito ao uso da responsabilidade social empresarial, há níveis de variação entre os casos abordados, sendo que nos casos da Pousada Cavalcante e da Pousada Pirenópolis é possível observar claramente a aplicação deste conceito e já no caso do Herbário essa prática não está explícita.

Com a intenção de explorar o histórico de criação de cada uma das cinco organizações selecionadas, foram feitas entrevistas em profundidade os empreendedores dos casos escolhidos. Os entrevistados foram: Fabrício Mendonça, da Pousada Pirenópolis; Antônio Silva, do Herbário; José Moura, da empresa Alimentos Orgânicos; André Souza, do Santuário e Sérgio Lemes, da Pousada Cavalcante. O roteiro de entrevista foi definido considerando as atividades do modelo de criação de empresas de Borges, Filion e Simard (2008) - Quadro 3 - e de acordo com a fundamentação teórica onde foram identificadas outras dimensões e temas importantes para a criação de empresas sustentáveis, mas resguardando a abertura para temas emergentes. As entrevistas foram gravadas e posteriormente transcritas.

Além dos dados coletados nas entrevistas, a pesquisa utilizou dados secundários, coletados na internet e nas próprias instituições. As entrevistas e demais dados coletados foram codificados e editados para a construção de tabelas-síntese de cada caso (MILES; HUBERMAN, 1994). Por fim, foram feitas análises intra e inter caso, com o intuito de reconstruir e comparar os processos de criação de cada uma das organizações, detectando as principais dificuldades nesse processo.

\section{Perfil das organizações analisadas}

A Pousada Pirenópolis foi inaugurada em 2003, na cidade de Pirenópolis, pelo empreendedor Fabrício Mendonça, que objetivava aplicar a experiência adquirida em consultoria e gestão de negócios investindo em um negócio ecossustentável. A ideia surgiu a partir da construção de alguns chalés para aluguel, que possibilitaram ao empreendedor a aquisição de conhecimentos voltados à sustentabilidade. Com a compra de um terreno em parceria com amigos, o empreendedor decidiu pela construção da pousada, que atualmente conta com 14 apartamentos, todos construídos a partir da valorização do conforto e segurança aliados à preservação do meio ambiente e dos aspectos socioculturais da comunidade local. Dentre as ações ecológicas e educacionais realizadas pela Pousada Pirenópolis estão: o projeto de reflorestamento ao redor da pousada para compensar a construção do estabelecimento, o reaproveitamento da água das chuvas, a reutilização de tijolos e telhas usadas, a divulgação de informações descritivas de árvores nativas em cada apartamento, o incentivo ao consumo de produtos do Cerrado, bem como a coleta e seleção do lixo reciclável.

O Herbário foi fundado pelo empreendedor Antônio Silva, conhecido como Herbário, que chegou a Alto Paraíso de Goiás em 1988, onde se instalou e fixou residência. Com base na experiência já adquirida em outros estados, o empreendedor decidiu dar continuidade ao trabalho já desenvolvido outrora e em 1990 começou a desenvolver as atividades do Herbário. Os produtos ofertados pelo Herbário, além das ervas medicinais, 
englobam xaropes, garrafadas, pomadas e artesanato indígena. Alguns produtos de artesanato são fabricados pelo próprio empreendedor, em seu ateliê, e outros são comprados diretamente de índios de diversas tribos. Já no que diz respeito à fabricação dos produtos medicinais, esta fica a cargo exclusivamente do empreendedor, que valoriza muito o fator credibilidade. Atualmente, o interesse de Antônio não está ligado a dinheiro, mas sim à tranquilidade de vida, à tradição, por isso ele não deseja expandir o negócio.

A empresa Alimentos Orgânicos, situada na cidade de Pirenópolis, surgiu em 2003 com a ideia de preservação do cerrado e utilização de seus frutos como forma de proporcionar melhoria de vida aos produtores rurais. Foi com base nessa ideia que o empreendedor José Moura e seu sócio desenvolveram o primeiro produto da empresa, naquela época ainda intitulada com outro nome, a barra de cereal com castanha de baru. As primeiras vendas, com o produto ainda em fase de experiência, foram realizadas apenas para amigos. À medida que o produto foi se aprimorando foram surgindo os primeiros clientes. Alguns meses depois do projeto inicial, José Moura decidiu romper a sociedade e foi quando a empresa passou a se chamar Alimentos Orgânicos. A partir daí, o empreendedor começou a desenvolver outras receitas e a negócio foi expandindo. Atualmente entre os produtos produzidos e vendidos pela Alimentos Orgânicos estão barras de cereais, pães, bolos e biscoitos.

Os empreendedores Pedro Souza e Vânia Souza adquiriram o Santuário em 1975, com o intuito de torná-la um pedaço de terra sustentável e assim proporcionar aos filhos qualidade de vida. Perceberam logo a riqueza do local e adotaram metas de preservação e sustentabilidade da propriedade. A comercialização de alguns produtos começou em Brasília, onde o empreendedor havia percebido a existência de demanda por produtos orgânicos. Dessa forma, logo a Fazenda já estava atraindo o interesse de amigos e alguns visitantes. Por volta dos anos 90, pressionados pelo turismo crescente em Pirenópolis, os empreendedores decidiram transformar a área em uma RPPN - Reserva Particular do Patrimônio Natural, e também fazer parcerias. Atualmente ela oferece diversos programas de turismo e educação ambiental envolvendo visitantes eventuais, grupos escolares e segmentos da comunidade de Pirenópolis, além de ter incrementado o Plano de Manejo com pesquisa de fauna e flora e a lista de espécies.

A pousada Cavalcante surgiu em 2002, do desejo do empreendedor Sérgio Lemes de estar mais próximo à natureza, desenvolvendo atividades ligadas a ela. O lugar escoIhido para a instalação do novo empreendimento foi a cidade de Cavalcante, tendo em vista o então potencial turístico da região. Logo no início da construção da pousada, graças a um projeto empreendido pela FUNATURA, a Pousada Cavalcante tornou-se uma RPPN - Reserva Particular do Patrimônio Natural. O lançamento oficial da pousada foi em agosto de 2003, quando toda a estrutura ficou pronta. A divulgação na internet e em revistas de grande circulação, além de parcerias com agências de turismo, foram ações importantes para fortalecer a imagem de empresa.

\section{Análise e discussão dos resultados}

Nesta seção serão apresentadas as principais atividades do processo de criação das empresas estudadas, e as dificuldades que foram detectadas por meio da análise comparativa dos casos. 


\section{Principais atividades do processo de criação}

De acordo com o modelo de Borges, Filion e Simard (2008), adotado como referência, o processo de criação de empresas divide-se em quatro etapas principais: iniciação, preparação, lançamento e consolidação. A seguir serão apresentados os momentos mais críticos dentro dessas etapas principais.

\section{Etapa de iniciação}

Esta etapa trata da identificação da oportunidade e da motivação para criar o negócio.

No caso do empreendedor Fabrício Mendonça, a ideia de criar uma empresa já era vislumbrada pelo empreendedor desde o ano de 1991, quando chegou à cidade de Pirenópolis. Ele almejava aplicar o conhecimento já adquirido com o serviço de consultoria construindo uma empresa que fosse autossuficiente e que possibilitasse ao empreendedor um gerenciamento mais à distância. Além disso, Fabrício, desde os 15 anos, graças ao contato com a mata do campus onde estudava e com o rio Araguaia, já sonhava em trabalhar com algo que estivesse ligado à natureza, ao desenvolvimento sustentável, que gerasse mínimos impactos. Por isso decidiu investir no ramo de hotelaria. Em 1997, surgiu a oportunidade de comprar um terreno em Pirenópolis em sociedade com dois amigos. Na sua parte do terreno, ele construiu a pousada na cidade.

O empreendedor Antônio Silva chegou à cidade de Alto Paraíso em 1988. Graças ao aumento da movimentação turística da cidade e à experiência adquirida em atividades anteriores, em outros estados, é que o trabalho com as ervas tornou-se um negócio. $O$ conhecimento que o empreendedor possui é uma herança de família - desde pequeno ele já estava acostumado a lidar com ervas e plantas e a tratar-se com produtos naturais. As intenções do empreendedor não são prioritariamente financeiras, o que o empreendedor almeja é obter seu sustento de forma tranquila, assim ele afirma: "a minha opção para ficar aqui já era porque era um lugar central no país e um lugar que não tinha progresso, não tinha movimentação de progresso".

José Moura é um dos empreendedores responsáveis pela criação da empresa Alimentos Orgânicos. Ele sempre foi ligado à área de alimentação, em especial a integral e a orgânica e chegou a Pirenópolis em 2001, onde já havia morado alguns anos antes. $\mathrm{Na}$ volta a Pirenópolis passou a fazer pães integrais e, de forma paralela, atuar como representante comercial de alimentos naturais. Logo em seguida, juntamente com um amigo, surgiu a ideia de utilizar o baru como matéria-prima para produção de barras de cereais. A ideia inicial da empresa, que a priori possuía outra denominação, já era pautada na preservação do cerrado e na utilização dos frutos do cerrado para proporcionar melhora de vida para os agricultores e produtores rurais.

A ideia do Santuário foi trazida da Bélgica, onde os empreendedores Pedro Souza e Vânia Souza conheceram uma comunidade alternativa autossustentável. A partir daí, os empreendedores idealizaram um pequeno pedaço de terra que fosse sustentável e que proporcionasse qualidade de vida para seus filhos. Ao comprar a fazenda, por volta dos anos 70 , começou a plantar para o próprio sustento e, graças à paixão pelas plantas, co- 
meçou a comercializar produtos orgânicos, dando origem ao que se tornaria o Santuário. O filho do casal, o empreendedor André, aponta como um dos motivadores que o ajudaram a empreender o curso do EMPRETEC, realizado pelo SEBRAE.

A decisão do engenheiro Sérgio Lemes em empreender no setor de turismo se deu por uma vontade antiga de trabalhar com a natureza, de ter um trabalho de preservação. Ele não se sentia satisfeito com o trabalho que realizava na indústria, ainda que em alguns momentos na área ambiental, e por isso idealizava poder sair da cidade e viver em contato mais próximo com a natureza, desenvolvendo atividades ligadas a ela. $\mathrm{O}$ empreendedor teve então a oportunidade de efetuar esta mudança, e assim surgiu a Pousada Cavalcante.

Pode-se perceber, através da análise dos casos, que em todos eles os empreendedores, de alguma forma, já haviam tido contato bem próximo com a natureza, o que os possibilitou idealizar a criação de um negócio sustentável. Todos almejavam uma melhor qualidade de vida e eram motivados pela paixão e pela vontade de contribuir com o meio. Em nenhum dos casos observa-se empreendedores movidos exclusivamente pelo interesse monetário.

\section{Etapa de preparação}

Esta etapa foca as atividades de planejamento e mobilização de recursos.

O empreendedor Fabrício Mendonça participou de todo o projeto de construção da pousada Pirenópolis. Ele afirma que, apesar de difícil, foi possível construí-la ainda que com pouco capital. Ele contou com o apoio da esposa, que é sócia, para sustentar a casa e investiu todo o dinheiro que possuía na pousada. Os recursos investidos para iniciar a pousada sempre foram próprios, porque, segundo o empreendedor, realizar um empréstimo só é indicado, em caso de hotelaria turística, para expansão, quando já houver clientela garantida e rentabilidade segura.

A principal ferramenta utilizada por Fabrício para obter as informações necessárias para o negócio é a internet. Ele acredita que as informações estão muito disseminadas e acessíveis e que, através dessas informações e de informações compartilhadas com amigos, pode-se criar qualquer coisa.

No caso do herbário, não houve planejamento. O empreendedor foi beneficiado pela movimentação turística da cidade e por ser muito conhecido no trato com plantas medicinais. Além disso, Herbário foi beneficiado também com a doação de um terreno pela prefeitura, que criou um bairro no intuito de expandir comercial e industrialmente a cidade.

A empresa Alimentos Orgânicos foi iniciada com um montante de $R \$ 30,00$, utilizados para compra da matéria prima necessária para a produção das primeiras barrinhas de baru. O empreendedor não faz referência a nenhum tipo de estudo de mercado ou planejamento para abrir a empresa. Mas ele cita que atualmente a pesquisa, o planejamento e o financeiro ficam a cargo principalmente de sua esposa, e que eles efetivamente ocorrem.

O Santuário foi, com o apoio da FUNATURA, uma ONG com sede em Brasília, a primeira RPPN - Reserva Particular do Patrimônio Natural - do estado de Goiás e uma 
das seis primeiras do Brasil. Isso possibilitou à fazenda mobilizar recursos financeiros através do apoio do Governo Britânico e de outras empresas. Ainda assim, grande parte dos recursos adveio dos próprios empreendedores. Houve uma preocupação, por parte dos empreendedores, de compreenderem, desde o início, o que o público, a clientela da região desejava, segundo afirma André Souza:

Porque a gente precisava entender o que esse turista queria da gente, a gente começou a lidar com turismo sem nenhum exemplo, de onde que a gente vai tirar um exemplo de um centro de visitantes? Não tinha! De onde a gente vai tirar uma trilha bem feita dentro de uma mata? Não tinha! Então assim, fomos os pioneiros na história de entender o público de Brasília, que é o nosso principal público, o que ele queria.

No caso da empresa Pousada Cavalcante, é possível perceber que houve uma preocupação no que tange à localização do empreendimento, conforme declara Sérgio Lemes:

(...) pesquisei diversos lugares no país onde poderia estar fazendo esse empreendimento, o objetivo dessa pesquisa era identificar locais onde o turismo, ele não estivesse totalmente estruturado, o objetivo era encontrar um lugar onde a coisa estivesse se desenvolvendo para entrar, não ter que entrar num mercado já saturado, um mercado muito competitivo, ter um diferencial já logo no ingresso.

O empreendedor fez um curso em uma empresa de São Paulo, sobre como montar e gerir uma pousada. Dessa forma, a escolha da propriedade foi previamente pensada e foi desenvolvido um projeto arquitetônico, o que revela certo planejamento por parte do empreendedor, ainda que ele não tenha feito um plano de negócios tradicional. Segundo ele:

(...) foi bem na "unha" mesmo. Óbvio que teve todo o planejamento, o fluxo físico e financeiro para a obra, tudo isso daí eu trouxe um pouco da experiência da indústria e coloquei numa forma um pouco mais simplificada, mas eu tentei fazer isso com algum tipo de critério, mas você pensar num negócio com taxa de retorno, não. Até porque o mercado era insipiente, não existia dados para você fazer qualquer tipo de análise, projeção, qualquer coisa do gênero.

A maior ferramenta de pesquisa para Sérgio é também a internet, ele acredita que a internet é uma fabulosa fonte de informações. Os recursos financeiros investidos inicialmente vieram do próprio empreendedor.

\section{Etapa de lançamento}

Esta etapa abrange a contratação e gestão de recursos humanos assim como o desenvolvimento do produto e as vendas.

A pousada Pirenópolis foi inaugurada no Réveillon de 2003, já com a primeira etapa construída, com uma quitinete e cinco apartamentos. A pousada iniciou com um fun- 
cionário, contratado na própria cidade de Pirenópolis, e o empreendedor, que na época morava em Goiânia, e ia juntamente com a família cuidar da pousada aos finais de semana. Por volta do ano de 2007, o empreendedor mudou-se com sua família para Pirenópolis e a segunda etapa da pousada foi finalizada, que consistiu na construção de um primeiro andar de apartamentos. Em 2009 foram construídos mais quatro apartamentos, totalizando 14 apartamentos. Segundo o empreendedor, todas as atividades dele são baseadas no conceito de permacultura. Por isso, tudo o que hoje há na pousada foi desenvolvido com o intuito de ser ambientalmente sustentável, desde o projeto de reflorestamento ao redor da pousada até a reutilização de tijolos e telhas usadas. Além disso, segundo Fabrício Mendonça:

a pousada cumpre também um papel de educação ambiental: todos os apartamentos têm o nome de árvores do cerrado, que são as árvores que tem no reflorestamento, as árvores nativas. (...) Então o hóspede tem a oportunidade de ver a importância daquela árvore, daquela planta para a humanidade.

O pessoal da pousada Pirenópolis sempre foi formalmente registrado e hoje a pousada possui cinco empregados, contratados na própria região. Além disso, são motivados a se conscientizarem no que tange às questões ambientais: uma das formas de motivação é a participação nos lucros advindos da venda do material reciclável recolhido.

Os primeiros clientes da pousada Pirenópolis foram amigos e as principais ferramentas que contribuíram para o aumento da clientela, segundo o empreendedor, foram a internet e a divulgação boca a boca.

No caso do Herbário, assim que o empreendedor chegou a Alto Paraíso teve que aperfeiçoar seus produtos: a embalagem, o rótulo, a documentação e registro tiveram que ser modificados, por exigências do mercado turístico da região e da vigilância sanitária. Além disso, como cada região tem um tipo de vegetação típica, o empreendedor teve que se adaptar também às ervas daquela região. O Herbário já é, desde a inauguração, formalmente registrado.

O empreendedor do Herbário chega a novas receitas e fórmulas geralmente aprendendo com outras pessoas, além de ler muito participar de encontros voltados a medicina natural. A principal forma de divulgação do empreendedor é a boca a boca.

As primeiras barrinhas da empresa Alimentos Orgânicos, na época com outra denominação, foram feitas com baru e vendidas para amigos porque, segundo o empreendedor, ainda estavam em fase de experiência. A barrinha só começou a ter a forma e o sabor almejados pelo empreendedor depois de algumas tentativas e, a partir daí, ela começou a ser vendida também em Brasília. Assim que o empreendedor desfez a sociedade e mudou o nome da empresa para Alimentos Orgânicos, começou a trabalhar com novos ingredientes, tais como castanha de pequi. E experimentou também novas receitas, produzindo pães, bolos, biscoitos e palitinhos. As novas receitas são elaboradas com base em tentativas e aos poucos vão sendo aperfeiçoadas. O empreendedor José Moura está sempre pesquisando novas ideias, seja na internet ou em conversas com amigos.

A clientela principal da Alimentos Orgânicos são os restaurantes e lojas de produ- 
tos naturais, e a maior parte das vendas destina-se a Brasília. $\mathrm{O}$ empreendedor acredita muita em vendas pela internet, apesar de ainda ter somente alguns clientes on-line. José Moura afirma que as primeiras vendas foram facilitadas pelo fato dele já ter trabalhado antes com a venda de outro produto integral, já possuindo, então, contato com esse tipo de mercado.

Além do empreendedor, a empresa Alimentos Orgânicos conta com mais três funcionários, dentre eles, a esposa e o filho de José Moura. A empresa atualmente ainda é informal, mas José Moura tem a intenção de registrá-la para poder ter acesso a determinados financiamentos e obter recursos suficientes para sanar os gargalos existentes no processo produtivo e logístico.

Os primeiros clientes do Santuário surgiram através das vendas de alguns produtos orgânicos em uma feira na cidade de Brasília, com a empresa ainda informal. À medida que essas vendas foram aumentando, foram crescendo também as vendas realizadas por telefone. Logo os empreendedores receberam a sugestão de transformar a fazenda numa RPPN - Reserva Particular do Patrimônio Natural - e com a transformação surgiram boas parcerias e a estrutura pode ser melhorada. Os primeiros visitantes apareceram após esta etapa, com a inauguração da RPPN em 1991 e a visita do príncipe Philip. Nessa época a empresa já começou a trabalhar com educação ambiental para escolas. Em 2004, o Santuário implantou o arvorismo e em seguida foram inaugurados também o rapel, o salto primata e o pêndulo, que são atividades de aventura, que, depois de um ano de adaptação, foram certificadas pela ABETA - Associação Brasileira das Empresas de Turismo de Aventura. Além disso, a fazenda ficou também conhecida por uma famosa refeição com 45 itens que é servida das $9 \mathrm{~h}$ às $16 \mathrm{~h}$.

No que diz respeito aos funcionários, o Santuário trabalha com 8 diaristas e 3 mensais durante os finais de semana regulares e o número de diaristas aumenta para 14 quando se trata de feriados. A principal ferramenta de divulgação do Santuário hoje é a boca a boca, ainda que haja um site, o empreendedor afirma que não há recursos suficientes para se investir em mídias. Quanto ao desenvolvimento de novos produtos, André afirma que são advindos majoritariamente de sua própria intuição.

A pousada Cavalcante começou oficialmente em agosto de 2003, quando a estrutura física da empresa ficou pronta. Todos os funcionários atuais da empresa são da cidade de Cavalcante, formalizados e totalizam um número de cinco. No começo, o empreendedor afirma ter sido difícil encontrar funcionários qualificados ao ramo, e por causa disso, a empresa tinha um turnover bem alto, que foi sanado graças a políticas implantadas na pousada de valorização da mão de obra, entre elas a política de participação na taxa de serviço, onde é sugerida uma taxa para o hóspede e o valor dessa taxa é distribuído entre os funcionários e a política de hospedar os próprios funcionários, dando a eles, esporadicamente, acesso gratuito aos serviços da pousada.

Para o desenvolvimento de novos produtos, Sérgio cita como uma das fontes o formulário de pesquisa que fica disponível para o hóspede, de onde, segundo ele, surgem algumas boas propostas. Além disso, o empreendedor acredita que viajar e observar o mercado também contribui para a adoção de novas práticas.

A principal ferramenta de divulgação apontada por Sérgio é a internet: a inserção da pousada nos diretórios de busca voltados à hotelaria que existiam na época. Além dis- 
so, ele afirma que a aparição da pousada em um guia de grande circulação e a transformação da área em uma RPPN também contribuíram.

\section{Etapa de consolidação}

A etapa de consolidação diz respeito à sobrevivência, ao crescimento e à gestão da empresa.

O empreendedor Fabrício Mendonça acredita que o fator ambiental, apesar de não ser determinante, é um dos fatores que ajudam a promover a pousada Pirenópolis. Ele afirma que tinha a intenção de desmistificar a associação entre ecologia e baixa qualidade. A ideia dele sempre foi proporcionar ao cliente conforto, qualidade e respeito ao meio ambiente. Segundo ele, esse fator ambiental funciona como uma espécie de filtro, atraindo um público mais exigente. Além disso, segundo Fabrício, por ser considerada uma pousada ecológica, a Pousada Pirenópolis já foi inclusive beneficiada pela geração de mídias espontâneas, o que contribui para o marketing da empresa. Uma das estratégias de gestão da Pousada Pirenópolis para atrair clientes é não aumentar o valor da tarifa nas férias. Fabrício acredita que com essa estratégia ele estará estimulando mais clientes a conhecerem a pousada, é o que ele denominou marketing presencial: fazer com que o cliente experimente o produto, graças à tarifa mais acessível, e assim volte mais vezes.

No que diz respeito à operação, quando ligada ao fator sustentabilidade, segundo Fabrício, esta se torna mais trabalhosa, principalmente na etapa de implantação dos processos, entretanto é também mais barata, já que há muita economia, tais como economia de água, de energia, em adubo, etc. Há ainda benefícios psicológicos, devido à qualidade de vida adquirida. Essa economia advinda de práticas ecologicamente corretas é que proporciona à pousada a possibilidade de manter tarifas abaixo da média. Mesmo sabendo que a empresa possui um diferencial, e que isso possibilitaria a cobrança de um adicional dos clientes, o empreendedor prefere fazer uso da estratégia de diminuir a tarifa e melhorar a taxa de ocupação da pousada. Além dessa, outra estratégia da qual Fabrício faz uso para tornar o seu empreendimento mais atrativo é a liberação de cortesias, para alguns membros do trading turístico e da mídia, de forma a aumentar a simpatia da pousada com o mercado.

No Herbário, além das ervas, há também a venda de artesanato, muitas vezes produzido pelo próprio empreendedor e outras vezes comprado de outros fornecedores, como grupos indígenas. Diferentemente dos remédios, ou das pomadas e xaropes, cuja produção é exclusiva ao Herbário, segundo o empreendedor, por uma questão de garantia. E não há fornecimento desses produtos para outras lojas. O interesse do empreendedor não é expandir o tamanho de seu negócio ou seus ganhos financeiros e sim garantir sua qualidade de vida. A única coisa ainda almejada por Antônio no sentido de crescimento é a aquisição de um pedaço de terra no intuito de desenvolver mais e melhor a parte de cultivo.

A clientela do Herbário são, em sua maioria, turistas. Poucos são os clientes moradores da cidade. Por isso, os melhores ganhos acontecem nas férias ou eventos. Essa alta temporada compensa o período de baixa temporada, controlando assim as receitas e despesas. Outro fator apontado pelo empresário é a inversão percebida por ele no que diz respeito às pessoas do interior e às dos grandes centros urbanos. Segundo Antônio, a 
conscientização sobre o uso das plantas e produtos naturais vem melhorando, entretanto a procura é maior por parte das pessoas dos grandes centros, sendo que as pessoas do interior procuram mais a medicina tradicional. Ou seja, as pessoas que estão mais próximas às plantas acabam dando menor credibilidade a elas.

A produção da empresa Alimentos Orgânicos atualmente abrange barrinhas de cereais, bolos, biscoitos, pães e palitinhos. Há fornecimento desses produtos para outras lojas e restaurantes de produtos naturais e toda a logística fica a cargo do empresário José Moura. Por isso, um dos desejos de José Moura é a aquisição de um caminhão melhor preparado para o transporte desses alimentos, o que ele pretende viabilizar com obtenção de financiamentos,

José Moura afirma também que não é complicada a produção de alimentos mais naturais, mas que há certa complicação no momento de vender, já que o mercado para esse tipo de produto ainda é limitado. Mesmo com ações de promoção dos produtos, o consumo de orgânicos atraem um público restrito, não atraindo, dessa forma, o investimento de grande parte dos varejistas de produtos alimentares, o que muitas vezes encarece esse tipo de produto.

No Santuário a gestão acontece da seguinte forma: o empresário Pedro Souza atua na área de consultoria e cursos, o empreendedor André Souza na área gastronômica e administrativa e a empreendedora Vânia Souza na área financeira.

Atualmente, no Santuário, são feitos 75 produtos e o público está estabilizado em torno de dez mil pessoas por ano. Segundo André, o fator sustentabilidade permite à empresa um leque maior de opções, permite aproveitar as diversas potencialidades naturais do Santuário, com a venda de variados produtos, fazendo com que não haja perda de matéria-prima. Para o empreendedor, um dos segredos está na forma de vender esses produtos, atingindo um maior número de pessoas.

André afirma também que a prestação de serviços no Santuário se torna complexa, devido à flutuação da demanda:

Começamos um turismo de forma correta e errada, errada porque o turista vem na hora que quer, faz o que quer, compra o que quer, tudo é quando quer, e correta porque às vezes o que quer também é gostoso para o turista, ele fazer aquilo, e a gente tem que entender o equilíbrio disso.

Afirma também que uma demanda mais certa proporcionaria uma melhor visão do negócio, definindo melhor os horários e estabelecendo limites à prestação dos serviços.

No caso da pousada Cavalcante, a mídia social tem sido uma das principais ferramentas de promoção. O empreendedor Sérgio Lemes acredita que o fator sustentabilidade contribui sim, e ele almeja dar maior ênfase a esse aspecto.

No que tange à política de preços, Sérgio afirma que ela é elaborada com base em benchmarking, ou seja, através do comparativo com outros empreendimentos de mesmo porte e atuantes no mesmo segmento. O empresário salienta ainda que considera a concorrência em sua região desleal, devido ao alto grau de informalidade, de empresas que não contribuem como deveriam com o governo e a fiscalização é omissa. $E$ devido a esse 
fator, ele afirma que trabalha com uma margem de lucro extremamente reduzida.

À semelhança do que acontece em outras pousadas, na Pousada Cavalcante também há produção de alguns itens, tais como pães, bolos, geleias, biscoitos, iogurtes, polpas de frutas, verduras, temperos. Além disso, a decoração da pousada é também produção artesanal do próprio local.

\section{Principais dificuldades no processo de criação}

As dificuldades identificadas em cada caso ao longo do processo de criação de suas organizações sustentáveis são mostradas no Quadro 4:

Quadro 4: Principais dificuldades detectadas no processo de criação das organizações analisadas.

Chart 4: Major difficulties encountered in the process of creation of organizations analyzed.

\begin{tabular}{|c|c|}
\hline \multicolumn{2}{|r|}{ Principais dificuldades detectadas } \\
\hline Pousada Pirenópolis & $\begin{array}{l}\text { Escassez de recursos financeiros. } \\
\text { Serviços públicos de má qualidade. }\end{array}$ \\
\hline Herbário & $\begin{array}{l}\text { Exigência da vigilância sanitária. } \\
\text { Conhecimento popular sujeito à extinção. }\end{array}$ \\
\hline Santuário & $\begin{array}{l}\text { Baixa qualificação e dificuldades com logística da mão-de-obra. } \\
\text { Processo complexo de certificação. } \\
\text { Desconhecimento prévio do processo produtivo. } \\
\text { Flutuação na demanda. }\end{array}$ \\
\hline Pousada Cavalcante & $\begin{array}{l}\text { Desconhecimento prévio do mercado. } \\
\text { Privacidade limitada. } \\
\text { Falta de ação governamental (na estrutura física, na oferta de subsídios para o de- } \\
\text { senvolvimento regional e na fiscalização de práticas empresariais predatórias). } \\
\text { Posicionamento geográfico desfavorável da cidade (dificuldades na logística e abas- } \\
\text { tecimento). }\end{array}$ \\
\hline $\begin{array}{l}\text { Empresa Alimentos } \\
\text { Orgânicos }\end{array}$ & $\begin{array}{l}\text { Falta de garantias no fornecimento de matéria-prima orgânica por produtores locais. } \\
\text { Falta de interesse das pousadas locais em adquirir produtos orgânicos. } \\
\text { Gargalos no processo produtivo. } \\
\text { Problemas logísticos na entrega dos produtos. }\end{array}$ \\
\hline
\end{tabular}

Fonte: Dados da pesquisa.

Source: Research data.

Pela análise das dificuldades apresentadas nos casos, podemos perceber que estas estão relacionadas a três categorias principais:

Dificuldades com serviços ou políticas públicas. Os obstáculos relacionados indireta ou diretamente ao governo foram citados nos casos da Pousada Pirenópolis, do Herbário, da Pousada Cavalcante e do Santuário. Conforme afirma o empreendedor Fabrício Mendonça, da Pousada Pirenópolis: "As maiores dificuldades que eu tenho como empresário não é nem em relação a eu ser sustentável ou não, são os serviços públicos de péssima qualidade".

Dificuldades relacionadas ao processo logístico ou de produção. Essas dificuldades podem ser observadas: no caso do Santuário, quando citam problemas com a logística da mão de obra e quando ressaltam que o desconhecimento prévio do processo produtivo foi um obstáculo; no caso da Pousada Cavalcante, ao afirmar que há um desfavo- 
rável posicionamento geográfico da cidade que gera dificuldades na logística e abastecimento; e especialmente no caso da empresa Alimentos Orgânicos, ao citar como dificuldades a falta de garantias no fornecimento de matéria-prima orgânica por produtores locais, os gargalos que integram o processo produtivo e os problemas logísticos na entrega dos produtos.

Dificuldades relacionadas à falta de planejamento. As dificuldades citadas nos casos do Santuário - flutuação na demanda - e da Pousada Cavalcante - desconhecimento prévio do mercado - poderiam ter sido solucionados com um planejamento estruturado.

\section{Conclusões}

O objetivo do presente trabalho foi o de analisar o processo de criação de empresas que exploram o nicho da sustentabilidade, as principais atividades que o constituem e as principais dificuldades encontradas pelos empreendedores.

Durante a análise, foi possível observar que as etapas do processo de criação das organizações sustentáveis analisadas ocorreram de uma forma semelhante ao sugerido pelo quadro de análise - Quadro 3 - o que indica a utilidade deste modelo também no nicho da sustentabilidade.

Além disso, foi possível perceber algumas atividades comuns entre as empresas analisadas: em todos os casos, os empreendedores já haviam tido algum tipo de contato com o meio natural, o que contribuiu com o desejo de criar um negócio sustentável; todos almejavam prioritariamente qualidade de vida, eram movidos pela paixão e pela vontade de contribuir com o meio e em nenhum dos casos o interesse era exclusivamente financeiro; no processo de criação, houve poucas atividades de planejamento, assim como poucas práticas estruturadas de promoção do empreendimento.

Observa-se também que além da adoção de práticas sustentáveis, tais como reflorestamento, reciclagem e educação ambiental, como nos casos da pousada Pirenópolis e do Santuário, há também uma preocupação no que diz respeito à responsabilidade social, representada no bom trato dos funcionários, relatado especificamente nos casos da pousada Pirenópolis, onde os funcionários são motivados à conscientização ambiental através da participação nos lucros advindos de materiais reciclados, e na pousada Cavalcante, que adota várias políticas de motivação e qualificação, entre elas a política de hospedar os funcionários na pousada, dando-lhes acesso gratuito aos serviços.

As principais dificuldades encontradas nos casos foram categorizadas da seguinte forma: dificuldades com serviços ou políticas públicas; dificuldades relacionadas ao processo logístico ou de produção; dificuldades relacionadas à falta de planejamento.

Os resultados obtidos com a pesquisa, através da reconstrução do processo de criação dos casos selecionados e posterior identificação das dificuldades presentes nesse processo, contribuem para facilitar e estimular a ação dos empreendedores sustentáveis em potencial, esclarecendo-os quanto ao processo que percorrerão para realizar a criação de sua organização, quais os principais desafios que encontrarão nesse processo, para que possam melhor se preparar na busca de soluções. Os resultados auxiliam também os gestores públicos a repensarem suas ações e a reformularem as políticas que vem sendo implantadas em favorecimento ao empreendedorismo sustentável. 
Para futuros estudos, sugere-se a abordagem da temática de políticas públicas voltadas ao setor de turismo, assim como a continuidade e maior aprofundamento da presente pesquisa, através da análise de mais casos do setor turístico.

\section{Referências bibliográficas}

BARBIERI, J.C.; VASCONCELLOS, I.F.G.; ANDREASSI, T.; VASCONCELOS, F.C. Inovação e sustentabilidade: novos modelos e proposições. RAE - Revista de Administração de Empresas, v. 50, n. 2, p. 146-154, abr./jun. 2010.

BORGES, C.; FILION, L. J.; SIMARD, G. Jovens Empreendedores e o processo de criação de empresas. RAM - Revista de Administração Mackenzie, Universidade Presbiteriana Mackenzie, v. 9, n. 8, nov./dez. 2008. Edição especial.

BORGES, C.; BORGES, M.M.; FERREIRA, V.R.S.; NAJBERG, E.; TETE, M.F. Empreendedorismo sustentável: proposição de uma tipologia e sugestões de pesquisa. ENCONTRO DA ANPAD, 35, 2011, Rio de Janeiro. Anais... Rio de Janeiro: ANPAD, 2011.

BOSZCZOWSKI, A. K.; TEIXEIRA, R. O empreendedorismo sustentável e o processo empreendedor: em busca de oportunidades de novos negócios como solução para problemas sociais e ambientais. ENCONTRO DA ANPAD, 33, 2009, São Paulo. Anais... São Paulo: ANPAD, 2009.

COSTA, F.J. Fatores de influência no interesse empreendedor: uma análise junto a estudantes de Turismo. Revista Brasileira de Pesquisa em Turismo, v.2, p.4-27, 2008.

DALMORO, M. A visão da sustentabilidade na atividade empreendedora: uma análise a partir de empresas incubadas. Revista Gestão Organizacional, v. 2, n. 1, p. 87-104, jan./ jun. 2009.

DEHEINZELIN, L. Economia criativa e empreendedorismo cultural. In: ENCONTRO DE ESTUDOS MULTIDISCIPLINARES EM CULTURA, 2., 2006, Salvador. Anais... Salvador: CULT, 2006.

DIXON, S.E.A.; CLIFFORD, A. Ecopreneurship - a new approach to managing the triple bottom line. Journal of Organizational Change Management, v. 20, n. 3, p. 326-345, 2007.

ELKINGTON, J. Cannibals with forks: the triple bottom line of 21st century business. Oxford, UK: Capstone Publishing Limited, 1998.

FILION, L.J. Empreendedorismo: empreendedores e proprietários-gerentes de pequenos negócios. Revista da Administração, v. 34, n. 2, abr./jun., p.05-28, 1999.

HISRICH, R.D.; PETERS, M.P.; SHEPHERD, D.A. Empreendedorismo. Porto Alegre: Bookman, 2009.

HOCKERTS, K.; WÜSTENHAGEN, R. Greening Goliaths versus emerging Davids: theorizing about the role of incumbents and new entrants in sustainable entrepreneurship. Journal of Business Venturing, v. 25, p. 481-492, 2010.

INSTITUTO ETHOS. O que é RSE. Disponível em: <http://www1.ethos.org.br/EthosWeb/ pt/ 29/o que e rse/o que e rse.aspx>. Acesso em: 21 set. 2012. 
LIMEIRA, T.M.V. Empreendedor cultural: perfil e formação profissional. In: ENCONTRO DE ESTUDOS MULTIDISCIPLINARES EM CULTURA, 4., 2008, Salvador. Anais... Salvador: CULT, 2008.

MACHADO, H.; MACHADO, H.V.; ST-CYR, L.; MIONE, A.; ALVES, M.C.M. O processo de criação de empresas por mulheres. RAE eletrônica, v. 2, n. 2, jul./dez. 2003. Disponível em <http://www.scielo.br/pdf/raeel/v2n2/v2n2a07.pdf>. Acesso em: 21 set. 2012.

MAIR, J; MARTI, I. Social entrepreneurship research: a source of explanation, prediction, and delight. Journal of World Business, v. 41, p. 36-44, 2006.

MELO NETO, F.P.; FROES, C. Empreendedorismo Social: a transição para a sociedade sustentável. Rio de Janeiro: Qualitymark, 2002.

MELO, L.J.; COHEN, M. Empreendimentos inovadores, nova mentalidade? Um estudo exploratório sobre a sustentabilidade empresarial em uma incubadora de empresas. In: ENCONTRO DE ESTUDOS EM ESTRATÉGIA, 4., 2009, Recife. Anais... Recife: ANPAD, 2009.

MILES, M. B.; HUBERMAN, A. M. Qualitative data analysis: an expanded sourcebook. Thousand Oaks, Calif: Sage, 1994.

MORETTO, C.F.; GIACCHINI, J. Do surgimento da teoria do desenvolvimento à concepção de sustentabilidade: velhos e novos enfoques rumo ao desenvolvimento sustentável. In: ENCONTRO DO ECOECO, 6., 2005, Brasília. Anais... Brasília: UnB, 2005. CD-ROM.

NASCIMENTO, E. P. Trajetória da sustentabilidade: do ambiental ao social, do social ao econômico. Estudos avançados, v. 26, n. 74, 2012.

ONOZATO, E.; TEIXEIRA, R. . Processo de criação de organizações com fins sociais: estudo de casos múltiplos na cidade de Curitiba - Paraná. In: ENCONTRO DE ESTUDOS SOBRE EMPREENDEDORISMO E GESTÃO DE PEQUENAS EMPRESAS, 5., 2008, São Paulo. Anais... São Paulo: 2008. CD-ROM.

PARRISH, B.D. Sustainability entrepreneurship: design principles, processes, and paradigms. Leeds, UK: University of Leeds, 2007.

PIMENTEL, T.A.B.; REINALDO, H.O.A.; OLIVEIRA, L.G.L. Empreendedorismo sustentável: uma análise da implementação da sustentabilidade empresarial em micro, pequenas e médias empresas industriais atendidas pelo PEIEX - no NUTEC. In: SIMPÓSIO DE ADMINISTRAÇÃO DA PRODUÇÃO, LOGÍSTICA E OPERAÇÕES INTERNACIONAIS, 13., 2010, São Paulo. Anais... São Paulo: FGV, 2010.

SCHALTEGGER, S. A Framework for Ecopreneurship. Greener Management International, v. 38, p. 45-58, 2002.

SCHARF, R. Manual de negócios sustentáveis. Como aliar rentabilidade e meio ambiente. São Paulo: Amigos da Terra - Amazônia Brasileira; Fundação Getúlio Vargas, Centro de Estudos em Sustentabilidade, 2004.

SHANE, S. Technological opportunities and new firm creation. Management Science, v. 47, n. 2, p. 205-220, fev. 2001. 
SHANE, S.; VENKATARAMAN, S. The promise of entrepreneurship as a field of research. Academy of Management Review, v. 25, n. 1, p. 217-226, 2000.

SHEPHERD, D.A.; PATZELT, H. The new field of sustainable entrepreneurship: studying entrepreneurial action linking "what is to be sustained" with "what is to be developed". Entrepreneurship Theory and Practice, v. 35, n. 1, p. 137-163, jan. 2011.

TEIXEIRA, R.M. Desempenho e obstáculos ao crescimento de pequenos negócios hoteleiros em Curitiba. Revista Turismo Visão e Ação - Eletrônica, v.14, n. 1, p. 99-117, jan./abr. 2012. Disponível em: < http://siaiweb06.univali.br/seer/index.php/rtva/article/ view/26 96/2169>. Acesso em: 21 set. 2012.

YIN, R.K. Estudo de caso - planejamento e métodos. Porto Alegre: Bookman, 2005.

YOUNG, W.; TILLEY, F. Can businesses move beyond efficiency? The shift toward effectiveness and equity in the corporate sustainability debate. Business Strategy and the

Environment, v. 6, n. 15, p. 402-415, 2006.

\section{Agradecimento:}

Os autores agradecem ao Conselho Nacional de Desenvolvimento Científico e Tecnológico (CNPq), agência do Ministério da Ciência, Tecnologia e Inovação (MCTI) do Brasil, pelo apoio na realização da pesquisa que subsidiou este artigo.

Thaynara Santiago Pereira: Universidade Federal de Goiás, Goiânia, GO, Brasil.

Email: thaynarasantiago@gmail.com

Link para o currículo Lattes: http://lattes.cnpq.br/9462573744575800

Cândido Borges: Universidade Federal de Goiás, Goiânia, GO, Brasil.

Email: candidoborges@gmail.com

Link para o currículo Lattes: http://lattes.cnpq.br/4803860037213326

Data de submissão: 13 de outubro de 2012

Data de recebimento de correções: 13 de outubro de 2012

Data do aceite: 04 de julho de 2013

Avaliado anonimamente 
Silva, G.V.; Pontes, A.N.; Pereira, A.M.; Lima, A.M.M. Contribuições da Educação Ambiental para o turismo em Bragança (PA) (Amazônia Atlântica): uma perspectiva participativa. Revista Brasileira de Ecoturismo, São Paulo, v.6, n.3, ago/out-2013, pp.778-799.

\title{
Contribuições da Educação Ambiental para o turismo em Bragança (PA) (Amazônia Atlântica): uma perspectiva participativa
}

\author{
Contributions of Environmental Education for tourism in Bragança (PA, Brazil) \\ (Amazon rainforest): a participatory approach \\ Glauce Vitor da Silva, Altem Nascimento Pontes, \\ Alexandre Macedo Pereira, Aline Maria Meiguins de Lima
}

\begin{abstract}
RESUMO
O turismo envolve diversos atores e segmentos da sociedade, além de investimentos em programas, projetos e produtos. Tais investimentos apresentam dinâmicas de interesses e benefícios diferentes, dependendo dos envolvidos (governo, comunidades, áreas protegidas, setor privado). Essa divergência ou convergência de interesses promove discussões sobre os efeitos desta atividade em relação aos recursos naturais. Um exemplo disso é o turismo da zona costeira que contém ambientes vulneráveis às ações antrópicas. Neste estudo, avaliou-se o município de Bragança (polo turístico Amazônia Atlântica no litoral nordeste do Pará), que apresenta como principal atrativo para a atividade turística o seu patrimônio cultural e paisagístico. A partir disso, foi proposta a discussão da relação entre as práticas de turismo desenvolvidas no município de Bragança e a demanda por ações de educação ambiental como um instrumento de construção de uma gestão participativa do turismo local. A pesquisa teve como objetivo identificar, no município, as variáveis de maior significado para uma análise das consequências sociais e ambientais da atividade de turismo, como as suas forças motoras, onde ocorre a maior pressão, as situações decorrentes, os impactos socioambientais gerados e as respostas possíveis de intervenção. Nesta abordagem, focalizou-se o papel da educação ambiental como instrumento de gestão social. Os resultados mostraram que a região sofre com elementos potenciais de pressão, principalmente pela necessidade de expandir a atividade de turismo em função da demanda por geração de emprego e renda. Logo, a educação ambiental deveria atuar como instrumento de articulação e mobilização para ampliar as discussões acerca das consequências dessas ações no município e sobre os sistemas naturais, incentivando o diálogo entre os atores envolvidos e fomentando a agregação de valor ao patrimônio existente, em favor de sua preservação.
\end{abstract}

PALAVRAS-CHAVE: Educação Ambiental; Gestão Participativa; Atividade Turística. 


\begin{abstract}
Tourism involves several actors and segments of society, as well as investments in programs, projects and products. These investments present dynamics of interests and different benefits, depending on the involved (government, communities, protected areas, private sector). This divergence or convergence of interests promotes discussions about the effects of this activity in relation to natural resources. One example of this is coastal zone tourism which contains environments vulnerable to anthropic actions. In this study, we evaluated the municipality of Bragança (tourist pole Atlantic Amazon in northeast coast of Pará), which presents as main attraction for tourist activity your cultural heritage and scenic. From this, it was proposed the discussion of the relation between tourism practices developed in the municipality of Bragança and the demand for environmental education actions as an instrument for construct a participatory management of local tourism. The research aimed to identify, in the municipality, the variables of greatest significance for an analysis of the social and environmental consequences of tourism activity, as its driving forces, where occurs higher pressure, situations arising, the socioenvironmental impacts generated and possible answers for intervention. In this approach, has focused on the role of environmental education as an instrument of social management. The results showed that the region suffers with potential elements of pressure, mainly by the need to expand the tourism activity due to the demand for employment and income generation. Therefore, the environmental education should act as a means of coordination and mobilization to broaden the discussion about the consequences of these actions in the municipality and on natural systems, encouraging dialogue between the actors involved and promoting value addition the existing patrimony in favor of its preservation.
\end{abstract}

KEYWORDS: Environmental Education; Participatory Management; Tourist Activity.

\title{
Introdução
}

O turismo é um conjunto das relações e experiências que se produzem como consequência da atividade. Para atingir a sustentabilidade no turismo é indispensável o esforço integrado dos atores desse processo, que buscarão associar os recursos naturais e culturais em uma ação de planejamento que estabeleça um desenvolvimento gradual e permanente, além de equitativo, do ponto de vista social, viável economicamente e comprometido com a preservação ambiental (IGNARRA, 2003).

De acordo com Trigo e Mazaro (2012), o turismo é uma atividade que pode trazer consequências que alteram o modo de vida de uma sociedade, seja de forma positiva: criação de empregos, geração de impostos e promoção do desenvolvimento, por exemplo; ou negativa: poluição, exclusão social, concentração de renda, aumento da prostituição e exploração sexual de crianças e adolescentes, entre outros. A responsabilidade por essas questões não é exclusiva dos governos (federal, estadual ou municipal), mas também da sociedade civil organizada como um todo.

O avanço dessa atividade não tem ocorrido de forma homogênea e igualitária, espacial e territorialmente, ao longo dos anos (CACHO; AZEVEDO, 2010). Os motivos são diversos, mas acabam se enquadrando dentro da relação sociedade versus patrimônio natural. Porém, um fato é perceptível, a contínua demanda do turismo pelo acesso à informação (NECHAR, 2011). Este avanço possibilitou que a sociedade se tornasse mais participativa no processo de construção das políticas públicas voltadas para o setor (PLASTINO et al., 2010; ESPÍNOLA; CASTRO, 2012; SILVA et al., 2012), visto que esta tem acesso rapidamente à informação e às consequências da implantação dos projetos 
em uma região.

No processo de construção das políticas públicas de turismo, a gestão participativa busca estabelecer diretrizes para o crescimento ordenado do setor. Para tanto, faz-se necessário planejar, o que significa equilibrar o atendimento às necessidades do turista e propiciar o bem estar de todos os sujeitos sociais envolvidos, o que implica em recompensar a comunidade que divide seu espaço com os turistas, financiando, com os recursos provenientes do turismo, as ações requeridas para melhorar a qualidade de vida dessa comunidade (SEVERINO; TOMASULO, 2012).

No alcance desta meta, destacam-se a necessidade de cultivar a conscientização da comunidade quanto ao valor e à necessidade de proteção do patrimônio natural e cultural, assim como os padrões de sustentabilidade de um crescimento local apropriado; além de envolver as pessoas nos planos de conservação e na gestão da área (AGUIAR et al., 2010).

Um dos meios para se resgatar valores fundamentais para a conservação e para um convívio harmônico entre diferentes culturas e entre essas e a natureza é a educação ambiental (SILVA, 2011), que surge como uma alternativa para a gestão ambiental associada à atividade turística. É importante promover ações estratégicas no planejamento turístico local, a fim de buscar valorizar a natureza, respeitar os limites de crescimento, buscar participação, democratização e emancipação igualitária (RABINOVICI, 2008).

A educação ambiental tem como objetivo central criticar o modelo de desenvolvimento capitalista, tendo em vista que esse modelo concebe a natureza como "recurso" natural e coisifica o homem em razão do lucro (LEFF, 2003). Ela se recusa a adotar práticas/ações pragmáticas que coloquem as populações vulneráveis como responsáveis pelos impactos ambientais e humanos (MÉSZÁROS, 2002).

No Século XX, a educação ambiental consagrou-se como instrumento de integração com uma diversidade de práticas e correntes que espelham bem a complexidade de contextos, problemas e visões da atualidade, incluindo as zonas costeiras. Dessas práticas e correntes teóricas, citam-se, segundo Carvalho et al (2011): a Naturalista (a qual busca reconstruir uma ligação com a natureza); a Conservacionista (de gestão); a Biorregionalista (ligada ao desenvolvimento comunitário, local e regional); a Crítica (que se volta para a investigação sobre a realidade e a resolução de problemas); e a Etnográfica (que valoriza a dimensão cultural).

Fortunato (2009) defende a ideia de que a educação ambiental e a atividade turística se assemelham, à medida que ambas estão preocupadas com as questões cotidianas e desejam contribuir com a melhoria do lugar onde se instituem, estabelecendo, assim, paralelos indissociáveis.

A partir do histórico de implantação do turismo no Brasil (TRIGO; MAZARO, 2012), observa-se que existe o confronto de duas realidades distintas: de um lado, os empreendimentos autárquicos, isolados e sem relações vinculantes com as comunidades do território onde estão situados; de outro, os empreendimentos associados a um planejamento envolvendo a gestão social (FABRINO et al., 2012). A implantação do turismo como atividade produtiva e o desenvolvimento local sustentável na região amazônica representam exemplos desta discussão. 


\section{Caracterização da área de estudo}

A Amazônia brasileira passou a ser conhecida como Amazônia Legal a partir da Lei 1.806/53, consequência de um conceito político e não geográfico advindo da necessidade do governo de planejar e promover o desenvolvimento da região. De acordo com o Art. 2ํㅜ desta lei, para efeito de planejamento econômico, a Amazônia Legal abrange a região compreendida pelos estados do Pará e do Amazonas, pelos territórios federais do Acre, Amapá, Guaporé e Rio Branco e, ainda, e partes dos estados de Mato Grosso, de Goiás e do Maranhão.

O Pará é a segunda maior unidade federativa do Brasil, com mais de um miIhão de quilômetros quadrados. Segundo Santos e Santana (2009), 23,7\% das áreas de florestas naturais da Amazônia Legal estão localizadas no estado.

A Amazônia Legal, em toda a sua extensão territorial, apresenta uma diversidade de sistemas hídricos, de fauna/flora, de paisagens, extenso acervo arquitetônico Português, Francês e Espanhol, conjunto de museus, além de ampla diversidade cultural de seus povos, constituindo-se, assim, em uma região com extraordinário potencial turístico. O Pará contém parte desse acervo, destacando-se a forte relação do território com os sistemas hídricos existentes.

Neste enfoque, o presente trabalho aborda uma região bem específica, que é a zona costeira do estado Pará, onde o governo estadual implantou o Polo Turístico Amazônia Atlântica (PARÁ, 2001). Esse polo é constituído pelos municípios de: Vizeu, Augusto Corrêa, Bragança, Tracuateua, Salinópolis, São João de Pirabas, Primavera, Santarém Novo, Maracanã, Marapanim, Curuçá, Vigia, Colares, Magalhães Barata, São Caetano de Odivelas, São João da Ponta e Quatipuru.

O Polo Turístico Amazônia Atlântica está situado na faixa do litoral atlântico do Pará, no nordeste do estado. De acordo com Pereira et al. (2006a), a região ou zona do salgado, como também é conhecida a área litorânea paraense, está protegida da descarga das águas barrentas do rio Amazonas pela Ilha do Marajó e pela vazão do rio Pará.

Segundo Sousa et al. (2008), a costa amazônica apresenta características hidrodinâmicas e climatológicas únicas no Brasil. O encontro da floresta amazônica com o oceano Atlântico propicia um cenário singular, com características específicas e com potencialidades à prática do turismo. Neste artigo é discutido o potencial de um dos municípios mais tradicionais do estado, localizado na zona do salgado (Polo Turístico Amazônia Atlântica), que é Bragança, cuja sede municipal foi criada pela lei Provincial n. 252, de 2 de outubro de 1854, conforme indica a Figura 1.

Em 2009, Bragança ficou entre os 21 municípios do Pará que receberam o título de Município Turístico, pela Companhia Paraense de Turismo (PARATUR), por alcançar uma pontuação significativa pela Resolução n. ${ }^{\circ}$ 002/09 desta Instituição. Bragança é conhecida como a "Pérola do Caeté", por sua localização às margens do rio Caeté. O município possui em seu território belas praias, monumentos históricos, manguezais, rios, igarapés, ilhas e uma forte cultura, que formam um cenário especial à visitação. 


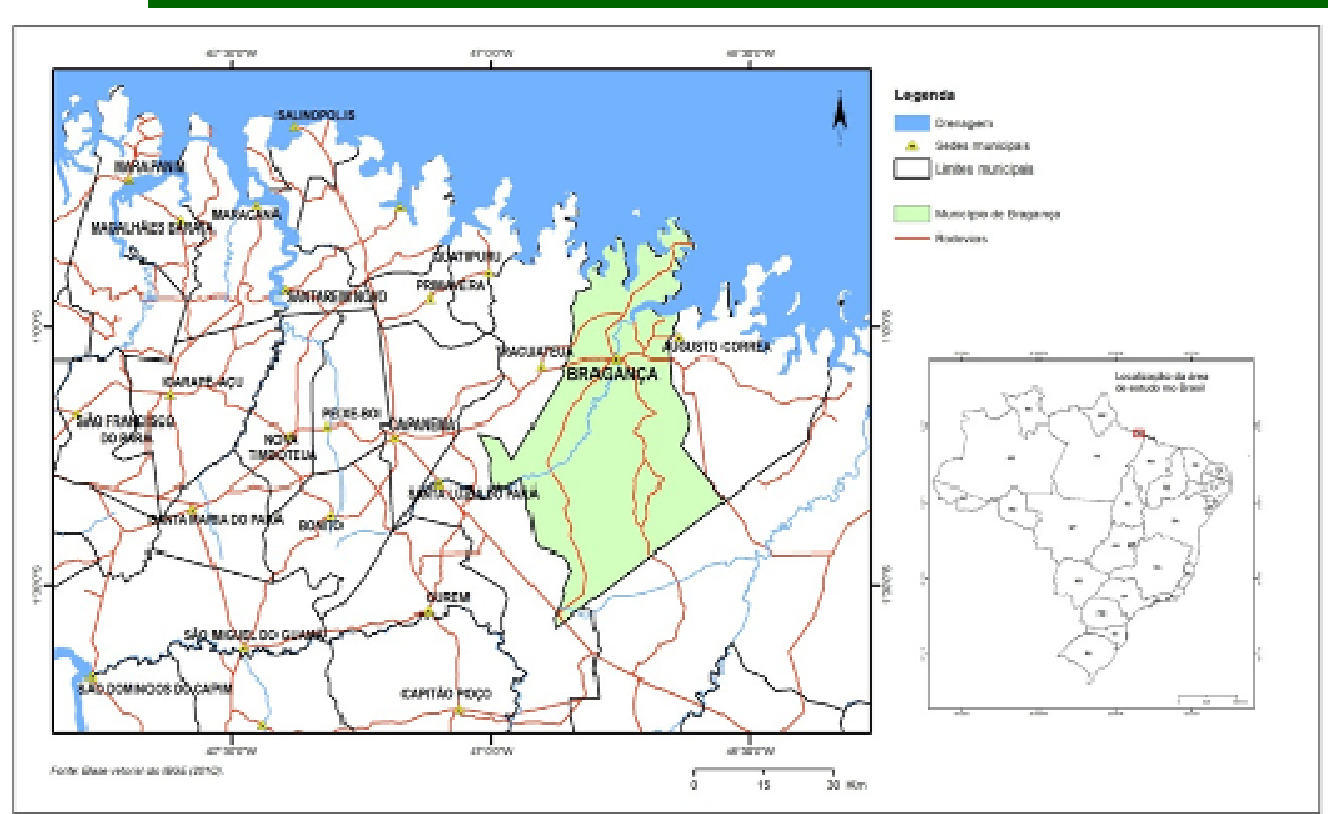

Figura 1: Município de Bragança na zona costeira do Pará. Fonte: autores.

Figura 1: Municipality of Bragança in the coastal zone of Pará. Source: by authors.

A gestão participativa não se centra em grandes investimentos econômicos, mas na participação efetiva das populações no processo de planejamento, execução e monitoramento das atividades nessas localidades (ESPÍNOLA; CASTRO, 2012). Nesse processo, a educação ambiental desempenha um papel importante.

A educação ambiental e a relação entre o turismo e o meio ambiente têm sido foco de estudos em várias publicações (LEAL-FILHO, 2005; NEIMAN; RABINOVICI, 2008; FORTUNATO, 2009; SANDEVILLE JR et al., 2010; SILVA, 2011; ESPÍNOLA; CASTRO, 2012) que se caracterizam por enfatizar a importância de articulação e envolvimento dos atores envolvidos direta ou indiretamente com a atividade turística, além da contribuição da educação ambiental para a prática do turismo pautada na sustentabilidade.

Ruschmann (2001) considera que, enquanto a indústria destrói para produzir, o turismo deve preservar para produzir, pois a atividade depende da harmonia do ambiente, sendo que a degradação deste afeta a competitividade do turismo local. Tal fato contrapõe-se ao observado no município de Bragança, que vem acumulando uma série de problemas de ordem ambiental, social e econômica em decorrência do turismo.

Entendendo-se a importância estratégica do Polo Turístico Amazônia Atlântica e do seu potencial ecológico, este trabalho teve como objetivo discutir a relação entre as práticas de turismo desenvolvidas no município de Bragança e a demanda por ações de educação ambiental como instrumento de construção de uma gestão participativa do turismo local.

\section{Principais fatores que qualificam a atividade de turismo na Região Bragantina}

Bragança possui uma diversidade de atrativos naturais e culturais. De acordo com o Inventário Cultural de Bragança, desenvolvido pela Fundação Hilário Ferreira, em 2010, 
além de um conjunto arquitetônico, que a diferencia das cidades do nordeste paraense, o município possui também praias, mangues, campos e igarapés. Bragança ainda oferece iguarias aos visitantes, como caranguejo, sururu, peixes diversos, camarão, ostras e frutas regionais. Uma das referências mais antigas de Bragança se relaciona com a cultura agrícola da mandioca, cujo principal produto é a farinha, conhecida por sua qualidade e sabor.

As atividades econômicas mais expressivas na estrutura produtiva do município de Bragança estão ligadas ao setor primário, com ênfase à pesca, à agricultura e ao extrativismo. Além dessas, há a atividade Turística, ligada ao setor terciário da economia.

Atualmente, o turismo encontra-se entre as quatro principais atividades econômicas do mundo (OLIVEIRA, 2007) e, acompanhando esse crescimento, o município vem caminhando gradativamente para a conquista de uma boa infraestrutura turística, percebida no desenvolvimento urbano, por meio da implementação de espaços de eventos e de novos pontos turísticos, como o Mirante de São Benedito, além da expansão do setor de serviços, principalmente na hotelaria e na gastronomia.

Bragança, segundo a PARATUR, alcançou uma pontuação superior a 70 pontos no documento que classifica os municípios por meio de itens vinculados a aspectos da gestão do turismo e à organização do trade turístico, ficando, assim, no nível mais elevado. A classificação ocorre hierarquicamente em: Município Turístico (nível mais alto), Município com Potencial Turístico e Município de Apoio ao Turismo.

Alguns dos critérios que elevaram Bragança a esta classificação podem ser observados na estrutura de lazer, apoio, serviços e equipamentos turísticos do município, contidos no Quadro 1.

Em relação à demanda, o fluxo de turistas em Bragança ocorre de forma sazonal, com ápice nos meses de fevereiro, julho e dezembro, quando ocorre o carnaval, o verão bragantino e a festividade de São Benedito, respectivamente. $O$ culto à tradicional Marujada e a São Benedito se constituem em importantes manifestações, cultural e religiosa, da Amazônia paraense. São mais de 200 anos de história (SILVA, 2006).

O potencial turístico atende a diversos segmentos: Ecoturismo, Turismo de Sol e Praia, Turismo Religioso e Turismo Histórico-Cultural; seus atrativos possibilitam aos visitantes lazer e satisfação todos os meses, e o fluxo de turistas no município chega aos milhares a cada ano.

A praia oceânica de Ajuruteua, que começou a ser explorada principalmente a partir da construção, em 1983, da PA-458, e que fica distante 36 quilômetros da sede municipal, representa um dos principais encantos turísticos de Bragança. Até o início da década de 1980, essa praia encontrava-se praticamente inabitada, segundo Pereira et al. (2006b).

Além da praia, o município também está rodeado por balneários de água doce que oferecem serviços básicos de alimentação e alguns promovem festas dançantes para atrair um público maior e mais diversificado. Contudo, existem opções aos que procuram um ambiente reservado e calmo, prezando pela tranquilidade. 
Silva, G.V.; Pontes, A.N.; Pereira, A.M.; Lima, A.M.M.

Quadro 1: Informações com base na pesquisa de demanda hoteleira realizada em 2011 pela Secretaria Municipal de Turismo de Bragança.

Frame 1: Information based on research of hotel demand in 2011 conducted by the Department of Municipal Secretary of Tourism of Bragança.

\begin{tabular}{|c|c|c|c|}
\hline \multirow{2}{*}{ Unidades } & \multirow{2}{*}{ Categorias } & \multicolumn{2}{|c|}{ Sistema de Hospedagem } \\
\hline & & Itens & Quantidade \\
\hline \multirow{4}{*}{$\begin{array}{l}\text { Sede de } \\
\text { Bragança }\end{array}$} & \multirow{4}{*}{ Hospedagem } & Hotéis & 10 \\
\hline & & Pousadas & 02 \\
\hline & & Dormitório & 01 \\
\hline & & Motéis & 03 \\
\hline \multirow{20}{*}{ Ajuruteua } & Hospedagem & Pousadas & 23 \\
\hline & \multirow{3}{*}{$\begin{array}{l}\text { Serviços de alimen- } \\
\text { tos }\end{array}$} & Restaurante & 17 \\
\hline & & Pizzarias & 04 \\
\hline & & Restaurante/Ajuruteua & 11 \\
\hline & \multirow{5}{*}{$\begin{array}{l}\text { Serviços e equipa- } \\
\text { mentos de agencia- } \\
\text { mento }\end{array}$} & Agências de Turismo & 01 \\
\hline & & Transporte interurbano & 01 \\
\hline & & Transporte zona rural & 07 \\
\hline & & Transporte zona urbana & 02 \\
\hline & & Transporte Ajuruteua & 01 \\
\hline & \multirow{3}{*}{$\begin{array}{l}\text { Serviços e equipa- } \\
\text { mentos para eventos }\end{array}$} & Espaços culturais & 01 \\
\hline & & $\begin{array}{c}\text { Empresas de organização e promoção } \\
\text { de eventos }\end{array}$ & 02 \\
\hline & & Auditórios e salões de convenções & 12 \\
\hline & \multirow{8}{*}{$\begin{array}{l}\text { Serviços e equipa- } \\
\text { mentos de lazer e } \\
\text { entretenimento }\end{array}$} & Balneários & 08 \\
\hline & & Praças & 10 \\
\hline & & Clubes & 01 \\
\hline & & Academias & 03 \\
\hline & & Estádios/Ginásios/Quadras & 09 \\
\hline & & Mirantes & 02 \\
\hline & & Prestadores de serviço e entretenimento & 01 \\
\hline & & Casas de espetáculo & 04 \\
\hline
\end{tabular}

Fonte: Secretaria Municipal de Turismo de Bragança, PA, 2012.

Source: Bragança's Municipal Secretary of Tourism, PA, 2012. 
O município de Bragança possui ainda duas Unidades de Conservação da Natureza (SNUC - Lei 9.985/2000): Ilha do Canela (APA - Municipal), instituída pela Lei № 3.280/97; e Reserva Extrativista Marinha Caeté-Taperaçu (RESEX - Federal), criada pelo Decreto n. 4.340/02.

Com tantos atrativos, fomentar a atividade turística de forma sustentável por meio da inserção social contribuirá para a consolidação de Bragança como um destino turístico com potencial regional, mediante um desenvolvimento competitivo da atividade.

\section{Aspectos socioambientais associados ao turismo}

Um dos grandes problemas socioambientais na região bragantina atinge as áreas litorâneas. Segundo Guerra et al. (2005), a expressão impacto socioambiental é entendida como um desequilíbrio ambiental e social ocasionado por uma influência antrópica, acarretando uma relação desequilibrada entre homem/natureza.

O município de Bragança apresenta áreas litorâneas com uma riqueza significativa de recursos naturais, com potencial turístico em expansão. Porém, os parcos investimentos em infraestrutura na região têm afetado o ambiente natural local. Silva et al. (2009) consideram que a maioria das construções, feitas sobre ou próximo à linha da costa, alteram o delicado equilíbrio entre o suprimento de sedimentos e o poder erosivo das ondas, reduzindo assim a flexibilidade natural da praia. A intensa ocupação desordenada por residências, meios de hospedagens, bares e restaurantes, na área praiana de Bragança, vem colocando em risco seu ecossistema costeiro.

Os ambientes costeiros na área do município sofrem constantes modificações naturais. Holzer et al. (2004) afirmam que as zonas costeiras são constantemente afetadas por processos naturais de deposição marinha (ação eólica e marinha) e de drenagem fluvial.

Em Bragança é possível observar a redução das áreas de floresta de mangues (PEREIRA et al., 2006a), que passam a compor uma paisagem com aspecto de "degradação", marcada pela perda das características naturais, com a transformação para uma nova categoria de ambiente. Um exemplo dessa situação foi a implantação da estrada que liga a sede do município à zona costeira.

Até o final da década de 70, a falta de acesso às praias da planície costeira bragantina era vista como um obstáculo ao desenvolvimento do turismo na região (SILVA et al., 2009). A construção da estrada impulsionou o turismo e facilitou o deslocamento e a comunicação dos pescadores locais com a sede do município e outras regiões do estado. Todavia, as consequências ambientais são observadas atualmente por todos os turistas que frequentam a área.

Esse corredor foi instalado sobre extensas áreas ocupadas por mangues, ocasionando uma transformação na paisagem. As perdas são sentidas pelas comunidades locais, especialmente aquelas dependentes do extrativismo do mangue.

O alto nível de vulnerabilidade dos ecossistemas costeiros deve ser levado em consideração pelos gestores que primam pelo desenvolvimento de seus municípios. Isso porque esses ecossistemas, muitas vezes, não comportam certas atividades, como o tráfego excessivo de veículos, instalações e infraestrutura inadequadas à paisagem local. 
Um problema presente e que afeta diretamente a atividade turística na região é o tratamento dado aos resíduos sólidos nas áreas costeiras, principalmente nas praias. A gestão pouco eficiente dos resíduos sólidos gera um duplo impacto nas áreas em questão: o primeiro refere-se ao impacto econômico pelo distanciamento dos turistas, visto que estes são atraídos pela beleza local e a presença de resíduos sólidos espalhados pelas praias altera a paisagem, comprometendo sua beleza. Já o segundo impacto é justamente a alteração da paisagem local.

Ao longo da zona costeira bragantina não foi observado nenhum sistema de coleta de lixo, sendo este depositado regularmente nos campos de dunas. Seu impacto varia desde a poluição da linha de costa até influências na saúde da população, além de problemas estéticos e econômicos que abalam o turismo da área.

\section{Metodologia}

A relação entre as práticas de turismo desenvolvidas no município de Bragança e a demanda por ações de educação ambiental, tendo como enfoque a gestão social participativa, foi construída a partir de etapas que associam as pesquisas de campo e documental. Como ferramenta analítica, foi empregado o modelo DPSIR (Driving Forces - Pressures State - Impact - Responses) de análise de variáveis e identificação de relações voltadas à qualidade ambiental (BIDONE; LACERDA, 2004; SVARSTAD et al., 2008; BELL, 2012; TSCHERNING et al., 2012).

Os trabalhos de campo tiveram como objetivo mapear as áreas de atividades turísticas, compreender a relação das populações locais com os empreendimentos turisticos implantados e analisar a forma de organização dessas populações para enfrentar os conflitos ali estabelecidos.

A abordagem teórico-metodológica desta pesquisa é de natureza exploratória e descritiva, realizada a partir da pesquisa qualitativa (ALVES, 2011). Para Sampieri et al. (1994), o uso da pesquisa exploratória é pertinente quando o foco é examinar uma temática com pouco ou nenhum estudo anterior, o que permite uma aproximação que favorece a familiarização com os fenômenos envolvidos no estudo. Sendo assim, os trabalhos descritivos procuram apresentar e identificar características de um fenômeno, população ou situação.

Pesquisa qualitativa é entendida como multi metodológica no que diz respeito ao seu objetivo, envolve abordagens interpretativas e naturalísticas dos fenômenos (ALVES, 2011). Denzin e Lincoln (1994) afirmam que o pesquisador, ao optar pela pesquisa qualitativa, se debruça sob os fenômenos em seu ambiente natural, com a finalidade de dar sentido ou interpretar os fenômenos, segundo o significado que as pessoas Ihes atribuem.

A etapa analítica buscou no modelo DPSIR um mecanismo para análise da relação turismo versus qualidade ambiental. Para tanto, de acordo com Borja et al. (2005), as Forças Motoras (Driving Forces) são normalmente consideradas como sendo políticas, econômicas e sociais dos governos; as Pressões (Pressures) são os caminhos em que esses elementos condutores são expressos e o modo como os ecossistemas e seus componentes são perturbados; essas pressões afetam o Estado (State) do ambiente, impactam (Impact) na saúde humana e nos ecossistemas, obrigando a formulação de Respostas (Responses). Estas últimas dar-se-ão por meio de várias medidas de política, tais como regulamentos, informações, impostos e planos diretores municipais. 


\section{Resultados}

\section{O processo de planejamento e gestão participativa do ecoturismo: análise empregan- do o modelo DPSIR}

O cenário identificado no município Bragança indica que o processo de participação efetiva da comunidade, de gestores, empreendedores e das associações no processo de gestão e desenvolvimento local é fundamental para a construção de uma perspectiva harmônica entre a atividade econômica e a natureza.

\section{1) Avaliação segundo os impactos sob os sistemas naturais locais}

O primeiro ponto de destaque é a questão do atrativo natural que a região apresenta. Essa força motora impulsiona as pessoas a explorarem ao máximo diferentes regiões. Entretanto, todas as vezes que algo novo "é descoberto", existe o apelo para que seja implantada a infraestrutura de apoio para facilitar a permanência do turista neste local (Figura 2).

\begin{tabular}{|c|c|}
\hline Variàvel & - Vulnerabilidade natural dos ecossistemas costeiros. \\
\hline $\begin{array}{l}\text { Forcas } \\
\text { Motoras } \\
\text { (Driving } \\
\text { Forces) }\end{array}$ & - Diversidade de atrativos naturais e culturais. \\
\hline $\begin{array}{l}\text { Pressöes } \\
\text { (Presșureș) }\end{array}$ & - Exploração do potencial. \\
\hline $\begin{array}{l}\text { Estado } \\
\text { (State) }\end{array}$ & $\begin{array}{l}\text { - Ambientes preservados com indicios de antropismo: desmate, resicuos sólidos e } \\
\text { prática do extrativismo predatorio da fauna local. }\end{array}$ \\
\hline $\begin{array}{l}\text { Impactos } \\
\text { (Impact) }\end{array}$ & $\begin{array}{l}\text { - Tráfego excessivo de veiculos. Instalaçóes e infraestrutura inadequadas à paisagem } \\
\text { do local. Falta de coleta e tratamento de ésgoto. Nắo rétirada de résiduos sólidos. } \\
\text { Poluição sonora e do ar. Redução do número de individuos naturais dos ambientes } \\
\text { de manguezais pela sua constante retirada. }\end{array}$ \\
\hline $\begin{array}{l}\text { Respostas } \\
\text { (Responses) }\end{array}$ & $\begin{array}{l}\text { - Gestáo ambiental municipal focada na promoçắ da estruturaçăo de um sistema } \\
\text { municipal de planejamento e gestäo urbana, democratizado, descentralizado, } \\
\text { integrado, permanente e continuo; no planejamento do espaço urbano e na } \\
\text { preservaçäo de ambientes protegidos, considerando os aspectos de saneamento, } \\
\text { controle do avanço imobiliario, manutença de areas verdes (Areas de Preservação } \\
\text { Permanente) e açóses educativas continuadas para o desenvolvimento do } \\
\text { ecoturismo. }\end{array}$ \\
\hline
\end{tabular}

Figura 2: Análise pelo modelo DPSIR das variáveis: avanço do turismo em áreas de vulnerabilidade, perda de biodiversidade a partir do processo de ocupação do seu entorno e constante visitação por parte dos turistas.

Figure 2: Analysis by DPSIR model of the variables: tourism advancement in areas of vulnerability, loss of biodiversity due to the progress of occupation and constant visitation by tourists.

Observa-se que a atividade, quando executada em ambientes que representam áreas de maior sensibilidade ambiental (USHER, 2001), passa a incorporar o conceito 
de pegada ecológica (CORDEIRO et al., 2010a), por representar uma demanda humana sobre os ecossistemas naturais, devendo assim contabilizar as perdas/ganhos existentes e inseri-los nas relações econômicas locais.

Gregory et al. (2013) empregaram o modelo DPSIR para orientar o processo de extrativismo de fauna marinha (Flamborough Head, UK). Na sua formulação de análise, também foi utilizada a lógica de incorporação dos impactos gerados pela atividade como forma de controle de sua expansão, destacando o envolvimento social e a avaliação da capacidade de suporte dos ecossistemas alterados como forma de Resposta.

Propõe-se, portanto, como Resposta, para o município de Bragança, que a gestão ambiental municipal incorpore, por meio de ações de controle e fiscalização junto aos investidores, as intervenções na fauna e flora locais, e na regulação do avanço imobiliário e comercial; de forma que os serviços básicos vinculados ao saneamento (esgotamento sanitário e coleta de lixo), abastecimento de água e fornecimento de energia se tornem mais "caros", por incorporarem os "impactos" gerados pela intervenção humana na faixa litorânea e nos manguezais. O desenvolvimento de ações de educação ambiental continuada visaria apoiar o reconhecimento social deste diferencial, para evitar sua rejeição por parte dos comerciantes e turistas que considerem "desnecessária" a incorporação do custo ambiental.

Cordeiro et al. (2010b) aplicam o Método da Pegada Ecológica do Turismo como uma ferramenta útil para avaliar a sustentabilidade de um destino turístico, na Região Autônoma dos Açores (Portugal). Considerando os pressupostos definidos por Gössling et al. (2002), que entende que devem ser agregados à atividade os consumos/resíduos compreendidos a partir de quatro categorias: transportes; acomodação; atividades; alimentação e consumo. Porém, para que esta proposta tenha uma boa receptividade, ela não pode ser entendida como um entrave para o desenvolvimento local pela população, disso advém a necessidade da participação social no processo de tomada de decisão.

O art. $4^{\circ}$ da Lei n‥ 3.875/06 (que dispõe sobre o Plano Diretor Municipal Participativo de Bragança) prevê a promoção da estruturação de um sistema municipal de planejamento e gestão urbana, democratizado, descentralizado, integrado, permanente e contínuo. A gestão democrática dar-se-á por meio da participação popular e da democratização das relações entre sociedade civil e o estado.

A gestão participativa e descentralizada é prevista tanto nas políticas ambientais (federal - Lei n. 6.938/1981; estadual - Lei n. 5.887/1995; municipal - Lei n. 4.035/2009) quanto na Política Nacional de Recursos Hídricos (Lei n. 9433/2007), além da estadual (Lei n. 6381/2001). Os debates sobre as questões do meio ambiente direcionam para que as atividades produtivas devam se desenvolver sob princípios ecológicos básicos, exigindo um componente social que incorpore esta limitação (MADRUGA et al., 2011). Dessa forma, é reconhecido que o equilíbrio entre a necessidade de desenvolvimento econômico municipal e o uso sustentável dos recursos naturais representa um desafio. 


\section{2) Desenvolvimento local (emprego e renda) e qualidade ambiental}

Para Fernández e Rivero (2009), crescimento econômico, qualidade de vida e qualidade ambiental devem estar em um mesmo patamar. Já os modelos de governança locais devem estar associados à internalização dos custos ambientais, à justiça social e ao desenvolvimento de um modelo econômico compatível com uma proposta sustentável. Isso conduz à ideia da importância da gestão social participativa vinculada ao ordenamento territorial em áreas de potencial para o ecoturismo. Disso advém o segundo ponto de análise, que relaciona o desenvolvimento local a um processo participativo e atuante na manutenção da qualidade ambiental dos sistemas naturais existentes (Figura 3).

\begin{tabular}{|c|c|}
\hline Variável & - Desenvolvimento econômico municipal, geração de trabalho e renda. \\
\hline $\begin{array}{l}\text { Forças } \\
\text { Motoras } \\
\text { (Driving } \\
\text { Forces) }\end{array}$ & - Implantação de um setor produtivo de suporte ao ecoturismo. \\
\hline $\begin{array}{l}\text { Pressóes } \\
\text { (Pressures) }\end{array}$ & - Crescimento sem considerar a capacidade de suporte local. \\
\hline $\begin{array}{l}\text { Estado } \\
\text { (State) }\end{array}$ & $\begin{array}{l}\text { - Concentraçăo de atividades em uma unica regiăo e sua expansăo sobré ambientes } \\
\text { destinados a preservação. }\end{array}$ \\
\hline $\begin{array}{l}\text { Impactos } \\
\text { (Impact) }\end{array}$ & $\begin{array}{l}\text { - Exploração dos recursos naturais e ampliação das consequências do antropismo } \\
\text { com a geração de poluiçắo e contaminaçăo ambiental. }\end{array}$ \\
\hline $\begin{array}{l}\text { Respostas } \\
\text { (Responses) }\end{array}$ & $\begin{array}{l}\text { - Gestão ambiental municipal e estadual atuante na formulaçäo de politicas e } \\
\text { implantaça de projetos voltados a preservaça de ambientes destinados a } \\
\text { proteção integral, incluindo o envolvimento social e do setor produtivo. Definiçăo de } \\
\text { uma politica de incentivos para o estimulo do ecoturismo e de atividades produtivas } \\
\text { vinculadas a este. }\end{array}$ \\
\hline
\end{tabular}

Figura 3: Análise pelo modelo DPSIR das variáveis: desenvolvimento econômico municipal, geração de trabalho e renda.

Figure 3: Analysis by DPSIR model of the variables: municipal economic development, employment and income generation.

Nesse caso, a qualidade ambiental está relacionada à capacidade de suporte do município (Figura 4). A questão do turismo de massa é bem atrativa na perspectiva econômica, pois gera uma renda ao setor produtivo local que equivale ao resto do ano de trabalho. Porém, as consequências desse setor são muito fortes, e confrontam 
com aquilo que se espera de um turismo sustentável baseado na lógica de que (SACHS, 2001):

- O ambiente é a principal fonte de matéria prima dos atrativos;

- O social (a comunidade receptora, o patrimônio histórico-cultural e a interação com os visitantes) demanda por um padrão de qualidade;

- O econômico (com todos os inter-relacionamentos e interdependências da cadeia produtiva) permite a articulação com as unidades de produção e de negócios viáveis identificadas nas comunidades, atuando de forma integrada, proativa e interativa, buscando incrementar a produtividade para o alcance de competitividade;

- O político se instrumentaliza mediante estratégias de gestão que possibilitem coordenar as iniciativas locais na criação de um entorno emulativo de produção, favorecendo o desenvolvimento sustentável.

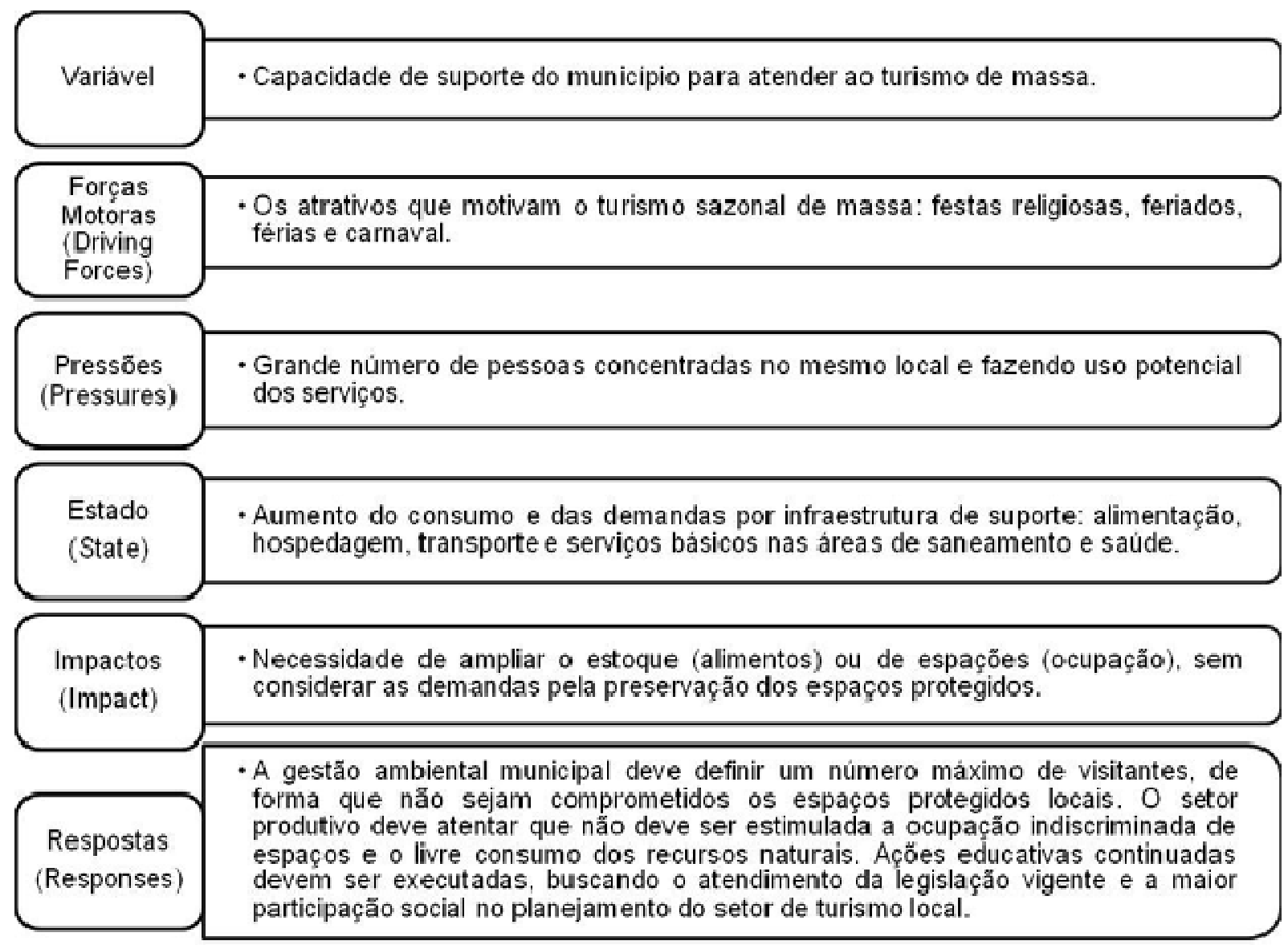

Figura 4: Análise pelo modelo DPSIR da variável: capacidade de suporte do município para a atividade de turismo.

Figura 4: Analysis by DPSIR model of the variable: carrying capacity of the municipality for tourism activity. 
Analisar a demanda econômica de desenvolvimento local e a capacidade de suporte, considerando as limitações que a infraestrutura municipal oferece e as restrições ambientais (legais), impõem Respostas embasadas na atuação conjunta entre a administração pública, o setor produtivo e a sociedade, que busca em Bragança um ambiente de lazer e de apreciação paisagística. Nesse sentido, destaca-se a Lei $\mathrm{n}$. 7.661/1988, que dispõe sobre o Plano Nacional de Gerenciamento Costeiro (PNGC), sua Revisão (PNGC II), de 1997, e o Decreto n. 5.300/2004, que regulamenta o uso e ocupação da zona costeira e fornece critérios de gestão da orla marítima.

Essas normas destacam a execução da gestão costeira em conformidade com o princípio da descentralização, assegurando o comprometimento e a cooperação entre os níveis de governo, e desses com a sociedade, no estabelecimento de políticas, planos e programas estaduais e municipais; tendo como um de seus instrumentos o Plano Municipal de Gerenciamento Costeiro (PMGC), que deve guardar estreita relação com os planos de uso e ocupação territorial e outros pertinentes ao planejamento municipal.

Para Atkins et al. (2011), o gerenciamento de ambiente costeiro deve envolver os setores associados aos produtos obtidos a partir dos ecossistemas locais, a regulamentação dos serviços ambientais e a incorporação dos serviços culturais.

Um exemplo de proposta que agrega emprego e renda com sustentabilidade é associada ao Turismo de Base Comunitária, que implica na participação da comunidade no planejamento e gestão do turismo, na conservação dos recursos naturais e/ ou culturais, no desenvolvimento econômico e social, na geração de benefícios econômicos e sociais para a comunidade local, na qualidade e na experiência do visitante, comprometido com a responsabilidade social e ambiental (FABRINO et al., 2012).

O município de Bragança incorpora tanto a oferta de serviços ambientais quanto culturais, por isso as Respostas definidas devem incorporar a sociedade no processo de tomada de decisões. Nessa proposta, a educação ambiental pode ser considerada como uma ação mediadora desse "feedback social", junto às políticas e/ou ações de planejamento envolvendo ações de controle ou mitigação, principalmente em função da pressão social pela garantia de emprego e renda para a população local (NESS, 2010).

\section{Discussão}

\section{A educação ambiental e o ecoturismo no município de Bragança: proposta de uma gestão partilhada}

Promover o ecoturismo em Bragança é uma exigência vocacional da região, que possui uma variedade de atrativos naturais e culturais. Todavia, é necessário compatibilizar o desenvolvimento econômico, a conservação dos recursos utilizados e a sustentabilidade socioambiental. Para Hanai et al. (2011, p.7), o desafio da sustentabilidade em destinos turísticos é urgente e requer o compromisso institucional das autoridades locais, assim como a colaboração ativa dos atores individuais que atuam nos destinos. 
Para que o ecoturismo possa ser desenvolvido respeitando a natureza, a cultura local e a participação da comunidade na tomada de decisões, assim como contribuir para que o turista tenha uma experiência rica e agradável, é indispensável investir no planejamento de atividades que compreendam os interesses coletivos.

Em Bragança, de forma geral, o turismo está entre as atividades econômicas mais expressivas na estrutura produtiva do município, pois sua contribuição estimula a melhoria da qualidade de vida da comunidade, uma vez que esta atividade abrange múltiplos componentes associados a outros setores da economia, no âmbito formal e informal (OLIVEIRA, 2007).

Além dos atrativos da zona costeira, trata-se de uma cidade histórica (a cidade de Bragança foi criada em 1854), que tem como maior manifestação de cunho cultural a Marujada, que se apresenta por ocasião da Festa de São Benedito. Logo, ao fomentar a atividade turística de forma sustentável, cria-se uma referência que ultrapassa seu sentido mercadológico, pois torna-se um segmento do turismo que estreita as relações de ações coletivas.

Para a mitigação dos problemas ambientais causados pelo fenômeno turístico e para o equilíbrio entre a necessidade de desenvolvimento econômico municipal e o uso sustentável dos recursos naturais, faz-se necessário atuar de forma continuada com ações de regulação que administrem tais impactos, sendo necessária a definição das relações de causa e efeito (QUARESMA; CAMPOS, 2006; PINTO, 2007).

A estrutura metodológica aplicada a esta pesquisa revelou alguns problemas identificados em sua área de abrangência, entre eles a perda de biodiversidade, consequência da ocupação desordenada do seu entorno e do aumento do fluxo de turistas, que exercem pressões diretas no ambiente, afetando as condições de vida da população com a intensa exploração de seu potencial e seus recursos, indicando a educação ambiental, associada à gestão ambiental pública, como resposta no sentido de mitigar tais inconformidades.

O método DPSIR, empregado neste estudo, considera que as atividades econômicas influenciam nos impactos ambientais (FERNANDES et al., 2011). Tal método permitiu considerar o desenvolvimento econômico municipal, a geração de trabalho e renda e a capacidade de suporte do município para a atividade de turismo como variáveis que apontam indicadores que induzem dimensões positivas, como o crescimento e a dinamização dos setores econômicos locais; e negativas, como a exploração dos recursos naturais, as desigualdades sociais e a perda da qualidade ambiental.

A avaliação por meio do DPSIR tem sido adotada com finalidades diversas, mas sempre voltadas a uma proposta de sistema de suporte a decisão para definição de ações e/ou políticas voltadas à minimização de impactos gerados pelas atividades humanas: Jago-on et al. (2008) aplicaram esse método em sete cidades metropolitanas asiáticas, focando nos problemas decorrentes da urbanização; Fernández e Rivero (2009) usaram o método para compor um índice aplicado ao turismo de base sustentável para 17 regiões na Espanha; Naviglio et al. (2009) avaliaram o método e suas aplicações voltadas à gestão e planejamento ambiental na Itália; Lončar (2010) o apli- 
ca à llha de Murter (Croácia), na identificação de ações que potencializem o desenvolvimento social e econômico, compatível com o ambiental, dentre estas as voltadas ao turismo; Fernandes e Barbosa (2011) formularam indicadores socioeconômicos e ambientais empregando o método, tendo como foco de análise o processo de desertificação em quatro municípios no Brasil (Araripina e Marcolândia/PI; Crato e Barbalha/CE).

A educação ambiental é uma "Resposta" sempre presente quando se analisa a sustentabilidade do setor de turismo, pois aparece como uma interlocução entre a comunidade e o poder público. Severino e Tomasulo (2012), em um estudo realizado em Santa Catariana, observaram que a participação dos moradores no turismo local atingiu $50 \%$ do percentual levantado. Para esses autores, a porcentagem confirma que o planejamento participativo e integrado pode ser uma realidade nos destinos turísticos; logo, se estruturado e articulado com ações continuadas, pode representar resultados positivos e continuados para a atividade.

Faz-se necessário, portanto, investir no planejamento de atividades que envolvam os atores da cadeia produtiva dessa atividade em sua dinamicidade (MAXIMIANO, 2007).

O planejamento participativo se firma em um processo democrático, fundamentado em mecanismos de participação direta, envolvendo as representações dos atores envolvidos (PAIVA, 2010). Esse processo, dentro do planejamento turístico, permite ampliar os questionamentos e a compreensão acerca dos problemas locais e ainda articular soluções que atendam ao interesse coletivo, por meio de um consenso social (KOGA et al., 2013).

Desenvolver o turismo sustentável e participativo demanda: valorizar o potencial turístico local; permitir o usufruto dos atrativos ambientais, culturais, patrimoniais e paisagísticos; assegurar à comunidade representatividade expressiva, com direito a voto nos conselhos deliberativos e consultar a comunidade previamente sobre a viabilidade ou não da implantação de qualquer atividade (RODRIGUES, 2009).

A partir das análises feitas, propõe-se o desenvolvimento de um Programa de Educação Ambiental com o objetivo de responder às demandas identificadas, relacionadas aos problemas ambientais. Enquanto ferramenta no processo de gestão participativa, a educação ambiental estenderá o uso da informação para expor ao turista o quanto determinado sistema é vulnerável, além de definir limites, à medida que se difunde uma consciência ecológica, por meio do estímulo à percepção coletiva sobre o meio ambiente e se desenvolvem habilidades de argumentação em defesa do interesse ambiental e social local (CARVALHO; COSTA, 2013).

\section{Considerações finais}

Os resultados apontados por meio do Modelo DPSIR indicaram algumas pressões exercidas sobre os recursos naturais, provenientes da atividade turística na região bragantina.

O turismo, durante muito tempo, foi considerado uma fonte de economia limpa (ou de forma mais apropriada atualmente - Economia Verde). Todavia, os impactos surgem no desenvolvimento da infraestrutura para a atividade turística por meio, por 
exemplo, de processos conhecidos como input (entrada), que diz respeito ao uso dos recursos naturais, e como output (saída), referente ao consumo e/ou geração de produtos que levam a formas de impactos poluidoras. $O$ estado do ambiente, registrado no método DPSIR, indica um alerta para os impactos e as transformações que desencadeiam problemas socioambientais em Bragança. A educação ambiental, sob a forma de ações no planejamento e na gestão social e participativa, é proposta como uma das ações inseridas no escopo de "Resposta" para esses problemas.

A atividade turística destaca-se na economia do município de Bragança. O turismo impulsiona a geração de emprego e renda para a comunidade e mobiliza outros setores que contribuem para o desenvolvimento local. O capital circulado durante o período em que o fluxo de visitantes é maior anima empreendedores e trabalhadores do setor informal que também se beneficiam com a renda. Os investimentos têm crescido e atraído novos recursos e serviços. Contudo, essa movimentação também tem trazido problemas socioambientais e culturais.

Empreender o ecoturismo em Bragança (associado ao turismo de base comunitária) permitiria a abertura de novos empreendimentos socioambientais dentro da prática do turismo, e de novos negócios sustentáveis envolvidos na cadeia dessa atividade econômica.

O município de Bragança, portanto, demanda por ações e políticas públicas que integrem, na administração municipal e estadual, ações de regulação, fiscalização e monitoramento à capacidade de suporte dos recursos naturais existentes. Nessa relação, a educação ambiental atuaria como uma forma de garantir o diálogo social, para maior internalização das ações e sua efetividade ao longo do tempo, tendo como focos a compreensão dos impactos do turismo sobre o meio natural, cultural e humano, a distribuição justa dos benefícios e custos, e a diversificação da economia local.

\section{Referências bibliográficas}

AGUIAR, P.W.; PADUA, S.M.; GOMES, M.A.O.; UEZU, A. Subsídios para o planejamento de trilha no Parque Estadual da Serra Furada (SC). Revista Brasileira de Ecoturismo, São Paulo, v. 3, n. 3, p. 498-527, 2010.

ALVES, M.L.B. Reflexões Sobre a Pesquisa Qualitativa Aplicada ao Turismo. Turismo em Análise, v. 22, n. 3, p. 459-613, 2011.

ATKINS, J.P.; BURDON, D.; ELLIOTT, M.; GREGORY, A.J. Management of the marine environment: Integrating ecosystem services and societal benefits with the DPSIR framework in a systems approach. Marine Pollution Bulletin, n. 62, p. 215-226, 2011.

BELL, S. DPSIR = A Problem Structuring Method? An exploration from the "Imagine" approach. European Journal of Operational Research, n. 222, p. 350-360, 2012.

BIDONE, E.D.; LACERDA, L.D. The use of DPSIR framework to evaluate sustainability in coastal areas. Case study: Guanabara Bay basin, Rio de Janeiro, Brazil. Reg. Environmental Change, 4:5-16, 2004. 
Contribuições da Educação Ambiental para o turismo em Bragança (PA) (Amazônia Atlântica): uma perspectiva participativa

BORJA, A.; GALPARSORO, I.; SOLAUN, O.; MUXIKA, I.; TELLO E M.; URIARTE, A.; VALENCIA, V. The European Water Framework Directive and the DPSIR, a methodological approach to assess the risk of failing to achieve good ecological status. Estuarine, Coastal and Shelf Science, n. 66, p. 84-96, 2006.

BRASIL, Lei no 1.806, de 6 de janeiro de 1953. Dispões sobre o plano de valorização econômica da Amazônia, cria a superintendência da sua execução e o conceito de Amazônia Legal. Diário Oficial da república Federativa do Brasil, Rio de janeiro, DF, 7 de jan. 1953. Disponível em: http://legis.senado.gov.br/sicon/index.jsp. Acesso em: 12 dez. 2012.

BRASIL. Decreto 4.340, de 22 de agosto de 2002. Dispõe sobre o Sistema Nacional De Unidades ee Conservação da natureza- SNUC, e da outras providencias. Disponível em: http://legis.senado.gov.br/sicon/index.jsp. Acesso em: 10 de jan. 2013.

CACHO, A.N.B.; AZEVEDO, F.F. O turismo no contexto da sociedade informacional. Revista Brasileira de Pesquisa em Turismo, v. 4, n. 2, p. 31-48, 2010.

CARVALHO, A.; AZEITEIRO, U.M.; MEIRA-CARTEA, P. Equipamentos para a Educação Ambiental na zona costeira da Euroregião do Eixo Atlântico: das práticas conservacionistas às sociocríticas. Revista de Gestão Costeira Integrada, 11(4): 433-450, 2011.

CARVALHO, B.C.; COSTA, V.C. Educação Ambiental na visão ecoturística: turismo e desenvolvimento local no município de Rio das Ostras (RJ). Revista Brasileira de Ecoturismo, São Paulo, v. 6, n. 1, p. 171-190, 2013.

CORDEIRO, I.D.; KÖRÖSSY, N.; PARTIDÁRIO, M.R. Instrumentos de avaliação de sustentabilidade de destinos turísticos: uma revisão de literatura. Caderno Virtual de Turismo, v. 10, n. 2, p. 49-64, 2010.

CORDEIRO, I. D.; KÖRÖSSY, N.; PARTIDÁRIO, M.R. The ecological footprint method for evaluating sustainable tourism: an case study of applied to the Azores Autonomous Region (Portugal). Revista Turismo Visão e Ação, v. 12, n. 3, p. 236-257, set-dez, 2010(b).

DENZIN, N.K.; LINCOLN, Y.S. Handbook of qualitative research. London: Sage Publication, 1994, $767 \mathrm{p}$.

ESPÍNOLA, R.S.; CASTRO, V.M. Ecoturismo e gestão participativa em Áreas Protegidas: o caso da Floresta Nacional do Tapajós (PA). Revista Brasileira de Ecoturismo, São Paulo, v. 5, n. 2, p. 281-296, 2012.

FABRINO, N.H.; COSTA, H. A.; NASCIMENTO, E.P. Turismo de Base Comunitária (TBC): elementos chaves para aferir seu desempenho na perspectiva da sustentabilidade. Revista Brasileira de Ecoturismo, São Paulo, v. 5, n. 3, p. 546-559, 2012.

FERNANDES, M.F.; BARBOSA, M.P. Aplicações dos Indicadores Socioeconômicos e Ambientais no Modelo DPSIR (Força Motriz/Pressão/Estado/Impacto/Resposta) e Influências na Desertificação nos Municipios de Araripina-PI, Crato e Barbalha-CE e Marcolândia-PI. Revista Brasileira de Geografia Física, v. 4, 722-737, 2011. 
FERNÁNDEZ, J.I.; RIVERO, M.S. Measuring tourism sustainability: proposal for a composite index. Tourism Economics, 15 (2), p. 277-296, 2009.

FORTUNATO, R.A. Representação social da educação ambiental e sua contribuição ao turismo. Revista Brasileira de Ecoturismo, São Paulo, v. 2, n. 2, p. 60-187, 2009. GÖSSLING, S.; HANSSON, C.B.; HÖRSTMEIER, O.; SAGGEL, S. Ecological footprint analysis as a tool to assess tourism sustainability. Ecological Economics, n. 43, p. 199-211, 2002.

GUERRA, A.J.T.; ALMEIDA, J.R.; ARAUJO, G.H.S. Gestão Ambiental de áreas degradadas. Rio de Janeiro. Editora Bertrand Brasil, 2005, 248 p.

GREGORY, A.J.; ATKINS, J.P.; BURDON, D.; ELLIOTT, M. A problem structuring method for ecosystem-based management: The DPSIR modelling process. European Journal of Operational Research, n. 227, p. 558-569, 2013.

HANAI, F.Y.; ESPINDOLA, E.L.G. Programa de Sensibilização Sustentável do Turismo: uma proposta para envolvimento e participação de comunidades locais. Turismo em Análise, v. 22, n. 1, p. 4-24, 2011.

HOLZER, W.; CRICHYNO, J.; PIRES, A.C. Sustentabilidade da urbanização em áreas de restinga: uma proposta de avaliação pós-ocupação. Paisagem Ambiente, $n$. 19, p. 49-65, 2004.

IGNARRA, L.R. Fundamentos do Turismo. São Paulo: Thomson Learning, 2003, $205 \mathrm{p}$.

JAGO-ON, K.A.B.; KANEKOB, S.; FUJIKURAC, R.; FUJIWARAB, A.; IMAID, T.; MATSUMOTOE, T.; ZHANGB, J.; TANIKAWAF, H.; TANAKAB, K.; LEEG, B.; TANIGU$\mathrm{CHIA}, \mathrm{M}$. Urbanization and subsurface environmental issues: An attempt at DPSIR model application in Asian cities. Science of the Total Environment, n. 407, p. 30893104, 2009.

KOGA, E.S.; OLIVEIRA, C.S.; KANESHIRO, D.M. Programa de capacitação do Projeto de Ecoturismo na Mata Atlântica no entorno dos parques estaduais paulistas. Revista Brasileira de Ecoturismo, São Paulo, v. 6, n. 1, p. 255-268, 2013.

LEAL-FILHO, W. A educação ambiental aplicada ao turismo: experiências da Costa de Caparica, Portugal. In: PEDRINI, A. G. Ecoturismo e Educação Ambiental. Rio de Janeiro: Publit, 2005. 25 p.

LEFF, E. (Org.). A complexidade ambiental. São Paulo: Cortez, 2003, 342 p.

LONČAR, N. The application of DPSIR model in analyzing the space and environmental state on Murter Island. Geoadria, 15/1, p. 49-80, 2010.

MADRUGA, L.R.G.; SILVA, T.N.; BEURON, T.; BLOCK, A. Comitê de Bacia: Uma Configuração Social Emergente na Gestão Sustentável das Águas. Desenvolvimento em Questão, v. 9, n. 18, p. 79-110, 2011.

MAXIMIANO, AC.A. Teoria Geral da Administração. São Paulo: Atlas, 2007, 521 p. 
Contribuições da Educação Ambiental para o turismo em Bragança (PA) (Amazônia Atlântica): uma perspectiva participativa

MÉSZÁROS, I. Para além do capital. Campinas, São Paulo: Boitempo, 2002, 1093 p.

NAVIGLIO, L.; CASTORINA, M.; BARBATO, F.; PACI, S.; SBRANA, M.; SIGNORINI, A. DPSIR: uno strumento di analisi ambientale applicabile a fini gestionali. Energia, Ambiente e Innovazione, n. 5, p. 85-96, 2009.

NECHAR, N.C. Epistemología crítica del turismo. Qué es eso? Turismo em Análise, v. 22, n. 3, p. 516-538, 2011.

NEIMAN, Z.; RABINOVICI, A. A educação ambiental através do ecoturismo: o diferencial das atividades de contato dirigido com a natureza. Pesquisa em Educação Ambiental, v. 3, n. 2, p. 77-101, 2008.

NESS, B.; ANDERBERG, S.; OLSSON, L. Structuring problems in sustainability science: The multi-level DPSIR framework. Geoforum, n. 41, p. 479-488, 2010.

OLIVEIRA, E.S. Impactos socioambientais e econômicos do turismo e as suas repercussões no desenvolvimento local: o caso do Município de Itacaré - Bahia. Revista Internacional de Desenvolvimento Local, v. 8, n. 2, p. 193-202, 2007.

PAIVA, M.G.M.V. Análise do Programa de Desenvolvimento do Turismo do Nordeste (PRODETUR/NE) na perspectiva do planejamento estratégico. Revista de Administração Pública. Rio de Janeiro 44(2): 197-213, 2010.

PARÁ. Plano de Desenvolvimento Turístico do Estado do Pará. Belém: PARATUR, 2001.

PEREIRA, A.P.F.G.; ANDRADE, F.A.G.; FERNANDES, M.E.B. Dois anos de monitoramento dos atropelamentos de mamíferos na rodovia PA-458, Bragança, Pará. Boletim do Museu Paraense Emilio Goeldi, Ciências Naturais, v. 1, n. 3, p. 77-83, 2006a.

PEREIRA, L.C.C; RIBEIRO, M.J.S; GUIMARÃES, D.O. ; SOUZA FILHO, P.W.M; COSTA, R.M. Formas de uso e ocupação na praia de Ajuruteua-Pará (Brasil). Desenvolvimento e Meio Ambiente, n. 13, p. 19-30, 2006b.

PINTO, P.M. Políticas de turismo e sustentabilidade em comunidades tradicionais: perspectivas conceituais. Bol. Mus. Para. Emílio Goeldi. Ciênc. hum., v. 2, n. 1, p. 11-22, 2007.

PLASTINO, M.R.; PEREIRA, D.C.; MAIA, M.G.M.; LOPES, D.A. Ecoturismo, cultura e comunidades: reflexões sobre o entorno da RPPN Santuário do Caraça (MG). Revista Brasileira de Ecoturismo, São Paulo, v. 3, n. 3, p. 382-407, 2010.

QUARESMA, H.D.A.B.; CAMPOS, R.I.R. Turismo como instrumento de ação coletiva em áreas pesqueiras do litoral da Amazônia. Bol. Mus. Para. Emílio Goeldi. Ciênc. hum. v. 1, n. 2, p. 139-147, 2006.

RABINOVICI, A. Organizações Não Governamentais, comunidades e turismo na Amazônia Brasileira: conflitos e sustentabilidade. In: Seminário Internacional Amazônia e Fronteiras do Conhecimento, 1, 2008, Belém. Anais IV ENANPPAS. Belém: UFPA, 2008.

RODRIGUES, J.M. Ecoturismo construindo a materialidade dos assentamentos: uma história de legitimação da terra no Distrito Federal - DF. Revista Brasileira de Ecoturismo, São Paulo, v. 2, n. 2, p. 118-141, 2009. 
Silva, G.V.; Pontes, A.N.; Pereira, A.M.; Lima, A.M.M.

RUSCHMANN, D. Turismo e planejamento Sustentável: a proteção do meio ambiente. Campinas: Papirus, 2001

SACHS, I. Caminhos para o desenvolvimento sustentável. Rio de Janeiro: Garamond, 2001, $95 \mathrm{p}$.

SAMPIERI, R.H.; COLLADO, C.F.; LUCIO, P.B. Metodología de la Investigación. México: McGraw Hill, 1994, 850 p.

SANDEVILLE JR, E.; SUGUIMOTO, F.T.; SILVA, C.E.L. Ecoturismo e (Des)Educação Ambiental. Revista Brasileira de Ecoturismo, São Paulo, v. 3, n. 1, p. 47-60, 2010.

SANTOS, R.B.N.; SANTANA, A.C. Comportamento recente do setor florestal madeireiro no estado do Pará, Brasil. Revista Árvore, Viçosa-MG, v. 33, n. 3, p. 533-543, 2009.

SEVERINO, S.; TOMASULO, S. Planos Estratégicos Municipais de Turismo do Estado de Santa Catarina - Roteiros Turísticos Regionais: um estudo. Turismo em Análise, v. 23, n. 2, p. 408-436, 2012.

SILVA, C.B. Educação ambiental para visitantes de unidades de conservação marinhas. Revista Brasileira de Ecoturismo, São Paulo, v. 4, n. 4, p. 509, 2011.

SILVA, D.B.R.N. Os Donos de São Benedito: convenções e rebeldias na luta entre o catolicismo tradicional e devocional na cultura de Bragança, século XX. 2006, $202 f$. Dissertação (Mestrado em História Social da Amazônia), IFCH/PPHIST. Universidade Federal do Pará, Belém: novembro, 2006.

SILVA, G.P.; NOGUEIRA, E.M.; PEREIRA, M.N.L. Promoção do turismo na Praia Grande (MA): entre a fantasia e a realidade no cenário do patrimônio cultural. Revista Brasileira de Ecoturismo, São Paulo, v. 5, n. 3, p. 530-545, 2012.

SILVA, I.R.; SOUZA FILHO, J.R.; BARBOSA, M.A.L.; REBOUÇAS, F.; MACHADO R.A.S. Diagnóstico ambiental e avaliação da capacidade de suporte das praias do bairro de Itapoã, Salvador, Bahia. Sociedade \& Natureza, Uberlândia, 21(1): 71-84, 2009.

SNUC. Sistema Nacional de Unidades de Conservação da Natureza. Lei n. 9.985, de 18 de julho de 2000. Brasília: MMA/SBF, 2000.

SOUSA, E.B.; COSTA, V.B.; PEREIRA, L.C.C.; COSTA, R.M. Microfitoplâncton de águas costeiras amazônicas: Ilha Canela (Bragança, PA, Brasil). Acta Botânica Brasileira, v. 22, n. 3, p. 626-636, 2008.

SVARSTADA, H.; PETERSENB, L. K.; ROTHMANC, D.; SIEPELD, H.; WÄTZOLD, F. Discursive biases of the environmental research framework DPSIR. Land Use Policy, n. 25, p. 116-125, 2008.

TRIGO, L.G.G.; MAZARO, R. Movimentos Globais e Cenários em Turismo: uma realidade dinâmica, uma viagem ao futuro. Turismo em Análise, v. 23, n. 3, p. 486-508, 2012.

TSCHERNING, K.; HELMING, K.; KRIPPNER, B.; SIEBER, S.; PALOMA, S.G. Does research applying the DPSIR framework support decision making?. Land Use Policy, n. 29, p. 102-110, 2012.

USHER, M. Landscape sensitivity: from theory to practice. CATENA, v. 42, n. 2-4, p. 375383, 2001. 
Glauce Vitor da Silva: Universidade do Estado do Pará, Belém, PA, Brasil.

Email: glaucevitor@yahoo.com.br

Link para o currículo Lattes: http://lattes.cnpq.br/0491000360565155

Altem Nascimento Pontes: Universidade do Estado do Pará, Belém, PA, Brasil.

Email: altempontes@hotmail.com

Link para o currículo Lattes: http://lattes.cnpq.br/5993352890364998

Alexandre Macedo Pereira: Universidade Federal do Rio Grande, Rio Grande, RS, Brasil.

Email: c.cpa2008@hotmail.com

Link para o currículo Lattes: http://lattes.cnpq.br/1811131513642380

Aline Maria Meiguins de Lima: Universidade Federal do Pará, Belém, PA, Brasil. Email: ameiguins@ufpa.br

Link para o currículo Lattes: http://lattes.cnpq.br/6572852379381594

Data de submissão: 04 de fevereiro de 2013

Data de recebimento de correções: $1^{\circ}$ de maio de 2013

Data do aceite: 14 de maio de 2013

Avaliado anonimamente 


\title{
Estudando o Centro Histórico de Natal (RN) e suas possibilidades para o turismo
}

\section{Studying the Historical Center of Natal (RN) and its possibilities for tourism}

\section{Patrícia Daliany Araújo do Amaral, Isabella Ludimilla Barbosa do Nascimento, Fábio Henrique da Silva}

\begin{abstract}
RESUMO
Busca analisar o potencial do Centro Histórico de Natal (RN) para o desenvolvimento de atividades relacionadas ao turismo cultural, apontando a importância deste espaço para o fortalecimento de um segmento ainda pouco desenvolvido na cidade. Para que o objetivo central fosse alcançado, foi necessário analisar suas principais edificações; verificar as estruturas físicas e as condições de acesso aos atrativos e; apontar alternativas de utilização dos referidos espaços. Trata-se de um estudo descritivoexploratório, de caráter qualitativo, que envolveu pesquisa bibliográfica e de campo. Aponta a importância da realização de um trabalho de educação patrimonial, para que a comunidade aproprie-se e se identifique com o centro histórico, valorizando-o. Esta questão pode fazer com que os espaços sejam preservados e se tornem mais atrativos aos turistas. Destaca-se, ainda, a necessidade de um trabalho de divulgação e dinamização de diversos espaços. Também devem ser consideradas questões como sinalização, acessibilidade, e informações disponíveis aos visitantes.
\end{abstract}

PALAVRAS-CHAVE: Centro Histórico de Natal; Patrimônio; Turismo Cultural.

\section{ABSTRACT}

It aims to make an analysis about the potential of the Natal's Historic Center (RN, Brazil) for the development of activities for cultural tourism, including the importance of that space to strengthening of a segment still undeveloped of the city. For reach the main purpose, it was necessary to analyze the main buildings; examine structures and access conditions of those touristic attractives; and find ways to utilize them. This is a descriptiveexploratory study, that's also has a qualitative character, which involved bibliographic and field research. Indicate the importance of a heritage education work, for the community have the opportunity to take ownership of this, identifying themselves with the historic center, and consequently, starting to valorize their own history. So, the space has a huge chance to be preserved and become more attractive for tourists. It's necessary to highlight the need of disclosure work and use of several spaces. It's necessary consider points like signaling, accessibility, and tourist informations.

KEYWORDS: Natal's Historic Center; Heritage; Cultural Tourism. 


\section{Introdução}

O artigo busca analisar o Centro Histórico de Natal (RN), a partir de uma apresentação das possibilidades de desenvolvimento do turismo cultural nessa cidade, visto que tal segmento vem crescendo e demonstrando resultados bastante positivos aos destinos turísticos que nele investem.

De acordo com uma pesquisa realizada pelo Ministério do Turismo em 2009, no qual eram investigados os hábitos de consumo dos turistas brasileiros, em relação ao principal motivo da escolha do destino turístico, conhecer a cultura e a população local aparece em terceiro lugar, com $13,2 \%$ do total dos entrevistados. Os dois primeiros lugares apontam para a busca por belezas naturais/natureza e praias, que totalizam $55,1 \%$ dos pesquisados. Este dado revela que se sobressai o número de turistas em busca de contato com a natureza, mas começa a ganhar espaço o interesse pelas questões culturais. Como Natal trata-se de um destino prioritariamente de sol e mar, agregar a questão cultural a essa oferta turística é uma possibilidade interessante para atrair um número maior de visitantes, assim como aumentar seu tempo de permanência no destino.

Como afirma Cascudo (1999), os primeiros bairros de Natal foram a Cidade Alta e a Ribeira, os quais presenciaram os primórdios da província, e deram início a um lento processo de povoação. Ainda hoje, vários prédios e monumentos da época são mantidos e alguns preservados, sendo testemunhos erguidos da história do povo natalense, a qual poderia ser contada também aos turistas que visitam a localidade e têm interesse em conhecer mais profundamente a cultura do local e da sua população.

Assim sendo, como objetivo central deste trabalho, propõe-se realizar estudo acerca do Centro Histórico de Natal, com vistas à efetivação de propostas para o desenvolvimento do turismo cultural nesta área. Para que tal objetivo fosse alcançado, foi necessário analisar o potencial turístico do Centro Histórico, através de suas principais edificações; verificar as estruturas físicas e as condições de acesso aos atrativos; assim como propor alternativas de utilização dos referidos espaços em estudo.

Trata-se de um estudo exploratório e descritivo, com uma abordagem qualitativa. Segundo Rodrigues (2007), o estudo exploratório refere-se à caracterização do problema, no qual é definida sua classificação. Desse modo, foram realizadas pesquisas bibliográficas e documentais referentes ao assunto abordado. Em relação à pesquisa descritiva, foi realizada a partir dos fatos observados e registrados, no qual não houve interferência direta do pesquisador. Para a coleta de dados, utilizou-se como procedimento metodológico a pesquisa de campo para aprofundamento de conhecimentos relacionados ao objeto de estudo, e foi realizada durante o mês de abril de 2012 no Centro Histórico de Natal.

A pesquisa justifica-se pelo fato de que turismo cultural é um segmento turístico que vem crescendo e se expandindo de maneira bastante positiva em todo o mundo. Em relação ao turismo de Natal, os principais atrativos trabalhados na venda do destino são sol e praia. Na verdade, não se trata de uma questão negativa, pois esses são recursos abundantes no Rio Grande do Norte; todavia, é preciso diversificar os rotei- 
ros ofertados à demanda real de turistas que visita Natal. Também é importante para atrair uma demanda de turistas em potencial que tem interesse específico nessa área.

Do ponto de vista da sociedade local, essa interação com o turista e a atividade turística é importante nos aspectos social e econômico, pois haverá contato da população com culturas distintas, e com a circulação de um número maior de pessoas no local, acarretará também na maior circulação de divisas. As motivações que levaram os autores à realização da pesquisa envolvem o interesse pela temática, assim como o fato de desenvolverem seus estudos relacionados à questão do patrimônio e do turismo cultural, ainda pouco desenvolvido na cidade do Natal-RN. Este artigo é resultado de uma etapa do projeto de pesquisa que estuda o Centro Histórico de Natal e suas possibilidades para o turismo cultural, no qual os estudantes são bolsistas do CNPQ (Conselho Nacional de Desenvolvimento Científico e Tecnológico).

\title{
Analisando o turismo cultural e o centro histórico de Natal
}

\section{Patrimônio e turismo cultural}

O sentido de patrimônio está relacionado com propriedade, herança paterna, dos que viveram antes e deixaram o seu legado e a sua história registrada em edificações para as futuras gerações. O patrimônio pode ser dividido em material e imaterial. O imaterial é composto pelas manifestações culturais, danças, aspectos culturais intangíveis como um todo, enquanto o material são os edifícios, monumentos, pinturas, dentre outros. Conservar essas construções é um meio de preservar e sempre lembrar fatos, acontecimentos históricos e do próprio desenvolvimento da cidade, construindo assim uma memória e criando um vínculo entre passado e o presente, por meio de afeição e de afetividade, tentando assim estabelecer uma relação e um sentimento de pertencimento do morador a sua cultura local (ABREU; CHAGAS, 2009). Todavia, o patrimônio, por si só, não dá conta de remontar e contar a história de uma cidade e de uma população. Segundo Martins (2006, p.39):

\begin{abstract}
O território em que vivemos é mais que um simples conjunto de objetos, mediante os quais trabalhamos, circulamos, moramos, mas também um dado simbólico. A linguagem regional faz parte desse mundo de símbolos, e ajuda a criar esse amálgama, sem o qual não se pode falar de territorialidade. Esta não provém do simples fato de viver num lugar, mas da comunhão que com ele mantemos.
\end{abstract}

A partir dessa afirmação, pode-se perceber que o patrimônio por si só não caracteriza uma identidade, e sim os símbolos, os significados, a relação entre a história e os aspectos que englobam esse legado com a comunidade local que preserva essa memória. Esse conjunto de valores e noções monta um cenário singular da história e do legado local, imprimindo assim a singularidade e a peculiaridade do lugar, formando sua identidade e exaltando sua importância para a sociedade. Com a valorização do patrimônio por parte do turismo, ele passará a ser mais notado e a sociedade local pode começar a enxergar os monumentos como parte integrante do seu passado e da sua história. 
A globalização e a rotina diária atribulada das grandes cidades vem trazendo grandes mudanças à sociedade. Com a intensificação desses processos, estimulouse nos homens o interesse em conhecer mais sobre sua história e seu passado. Dessa forma, essa questão abriu portas para o conhecimento de novas culturas e o compartilhamento de experiências entre elas (DIAS, 2006).

Cada vez mais, as pessoas buscam acesso às informações, inclusive nos seus momentos de lazer, quando também praticam turismo. Durante as viagens, é natural conhecer a história e o patrimônio das cidades que visitam, e que têm realidades distintas das suas. $O$ turista cultural busca conviver com essa cultura e procura interagir, tendo um contato mais próximo com a população local. A atividade do turismo cultural assume, assim, um caráter educativo e integrador, de forma que essa troca de experiências possibilita também uma troca de informação e conhecimento. Essa interação é a premissa básica para esse segmento, no qual o visitante entra em contato com os costumes, os hábitos, a história e tudo que está relacionado à população autóctone.

Geralmente, as atividades que envolvem o patrimônio incluem visitas que também são realizadas nos centros históricos, o que pode acarretar efeitos positivos. Pode-se apontar um prédio antigo que possui um fluxo de turistas, o qual dificilmente será derrubado ou vendido. Ademais, será preservado e se possível, será restaurado e adequado para atender às necessidades e interesses dos visitantes (BARRETTO, 2000). Essa preservação contribui não somente para conservar os patrimônios culturais, mas também para manter viva a história e as raízes culturais da cidade, para que a população possa se identificar com esses aspectos e criar sua própria identidade cultural. O turismo cultural é uma alternativa para fugir do turismo de massa, por se tratar de um segmento que atrai turistas com maior nível educacional e que respeitam o meio cultural e ambiental que visitam (BARRETTO, 2007). Segundo Richards (2005, p.1):

\begin{abstract}
O turismo cultural tem sido identificado como uma das áreas de maior crescimento nos últimos anos no turismo em geral. Entretanto, a pesquisa em turismo cultural não seguiu o mesmo ritmo que o crescimento do mercado. Um dos motivos da falta de pesquisas é a diversidade da "cultura" que os turistas consomem, o que, por sua vez, torna difícil definir o turismo cultural.
\end{abstract}

Apesar dessa complexidade, vários autores definem-no como sendo um segmento que se estrutura a partir da visitação ou do conhecimento, in loco, de recursos de origem cultural (COSTA, 2009). A partir disso, pode-se perceber que a história e a identidade de um povo são essenciais para a vivência do mesmo. Dessa forma, é importante para uma localidade turística que ela possua espaços capazes de apresentar a sua própria história, e demonstrar através de seus patrimônios um pouco da população local.

Se o turismo cultural for bem planejado e trabalhado, seus efeitos podem ser maximizados. Haverá a valorização do patrimônio cultural, onde a comunidade irá en- 
cará-lo como parte da sua história, e isso fortalecerá sua identidade cultural e o seu sentimento de pertença. Além disso, aumentará a circulação de pessoas de culturas distintas e este fato proporcionará o compartilhamento de informações e o desenvolvimento intelectual delas, de forma que esse aumento possibilite a melhoria ou a construção de novos estabelecimentos comerciais. Esses, por sua vez, irão gerar uma renda para comerciantes locais. Outros fatores ainda podem ser trabalhados, e podem até modificar o estilo de vida e melhorar a qualidade de vida da população local (DIAS, 2006).

Cidades históricas brasileiras, como é o caso de Ouro Preto e Salvador, investem na preservação de seu patrimônio, assim como na divulgação de roteiros de visitação aos centros históricos da cidade, o que atrai um número significativo de turistas interessados em conhecer a história do lugar e também de sua população local. Segundo Martins (2006), o que mais interessa e desperta a atenção do turista em seus momentos de viagem são os aspectos peculiares de cada destino, assim como o modo de vida da sociedade local como um todo. Dessa forma, percebe-se que um dos fatores de diferenciação entre um lugar e outro é a sua história, suas raízes, e como isso se apresenta em cada localidade.

\section{O Centro Histórico de Natal}

O Centro Histórico de Natal possui vários edifícios e um patrimônio histórico que remete a importantes acontecimentos na cidade, concentrados nos bairros da $\mathrm{Ci}$ dade Alta e da Ribeira, por serem os primeiros bairros da cidade. As primeiras movimentações e construções arquitetônicas que ainda permanecem preservadas surgiram na Cidade Alta. Algumas não são originais, mas ainda assim sua estrutura possui grande valor histórico para a cultura potiguar. O traçado urbano da cidade continua ainda em sua maioria com suas conjunturas iniciais, e apesar do tempo e do desenvolvimento urbano, a configuração das ruas e dos quarteirões ainda continua com as mesmas características da época da construção da cidade (MELO; SILVA FILHO 2007).

O seu acervo é formado por várias edificações de diversos estilos arquitetônicos construídos em distintas épocas da história. De maneira geral, algumas edificações são do período colonial, no qual apesar de alguns terem sido destruídos com o passar do tempo, ainda existem exemplares da época, de forma que retratam o início da colonização e do povoamento da cidade.

Durante o século XVII, os bairros da Cidade Alta e da Ribeira constituíam os limites da cidade, que contava com poucos moradores e também tinha como única edificação a igreja matriz. Nessa época, a cidade pouco se desenvolveu (Figura 1). 


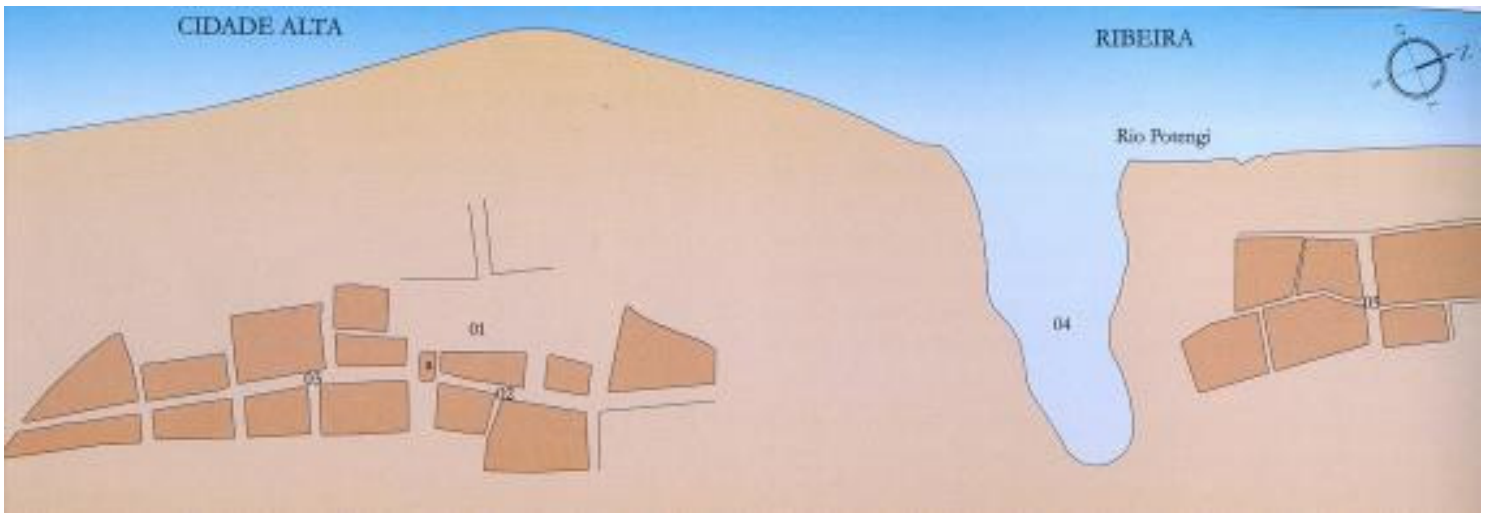

Figura 1: Mapa de Natal por volta de 1690 (imagem constituída após pesquisa documental). Fonte: Mendes (2007).

Figure 1: Map of Natal circa 1690 (image formed after documentary research).

Source: Mendes (2007).

Já no final do século XVIII, nota-se um desenvolvimento considerável na cidade em relação ao século anterior, no qual se vê mais ruas e mais construções pelos dois bairros, inclusive uma ponte interligando ambos (Figura 2).

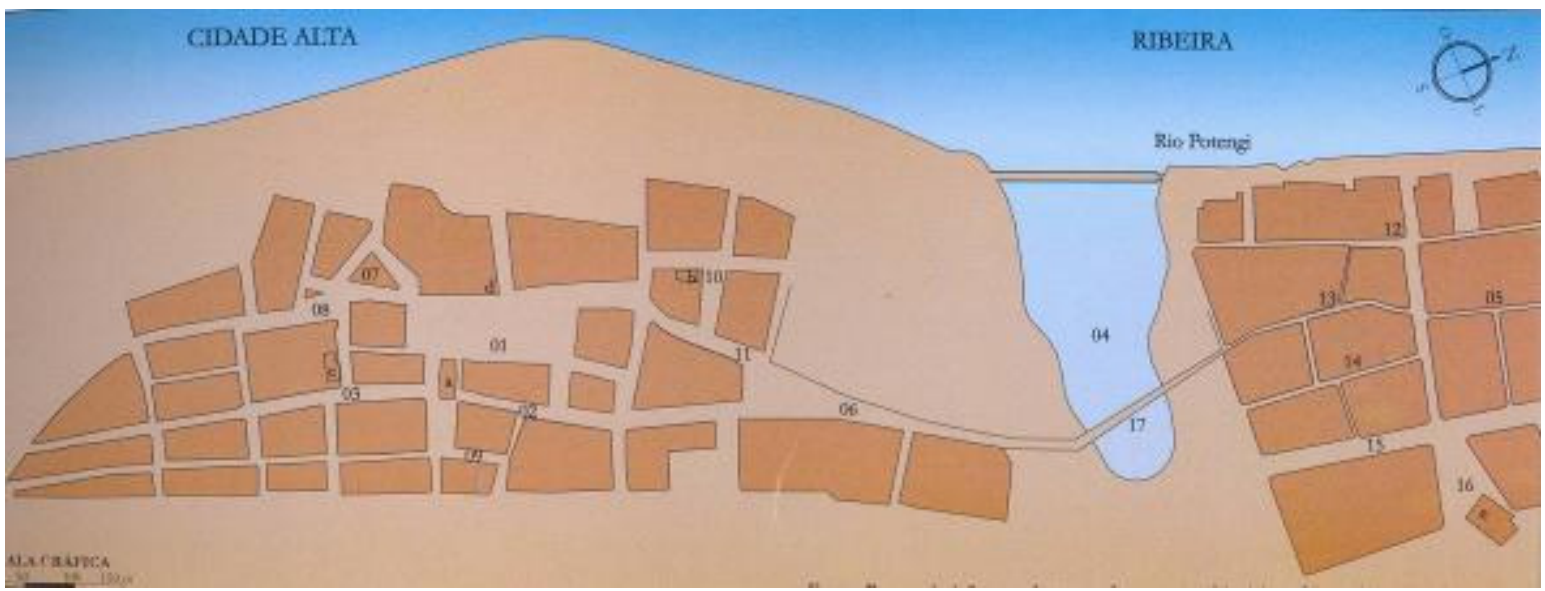

Figura 2: Mapa de Natal por volta de 1790 (imagem constituída após pesquisa documental).

Fonte: Mendes (2007).

Figure 2: Map of Natal circa 1790 (image formed after documentary research).

Source: Mendes (2007).

Não somente o número de edificações cresceu, mas a dinâmica social e o comércio ficaram mais intensos. Mas apesar disso, Natal ainda não se configurava como uma grande cidade e crescia a curtos passos, conforme aponta a descrição de Natal, por Henry Koster: 
As construções foram feitas numa elevação a pequena distância do rio, formando a cidade propriamente dita porque contém a Igreja Matriz. Consiste numa praça cercada de residências, tendo apenas o pavimento térreo, as igrejas que são três, o palácio, a câmara e a prisão. Três ruas desembocam nesta quadra, mas elas não possuem senão algumas casas de cada lado. A cidade não é calçada em parte alguma e anda-se sobre uma areia solta, o que obrigou alguns habitantes a fazerem calçadas de tijolos ante suas moradas. Esse lugar contará seiscentos ou setecentos habitantes. [...] (KOSTER, 1978, p. 110).

À tarde, saímos passeando para ver a cidade baixa. É situada nas margens do rio e as casas ocupam as ribas meridionais e não há, entre elas e o rio, senão a largura da rua. Essa parte pode conter 200 a 300 moradores e aí residem os negociantes do Rio Grande (KOSTER, 1978, p.110).

Como é possível verificar, o primeiro trecho trata do bairro da Cidade Alta, cuja infraestrutura ainda continuava sem grandes avanços e sem grande desenvolvimento das construções. O segundo trecho descreve o bairro da Ribeira, que concentrava a parte comercial de Natal, até então pouco desenvolvida. Somente no final do século XVIII e início do século XIX que realmente há mudanças e avanços na cidade, com a sua urbanização e modernização de sua infraestrutura.

Em um contexto mais abrangente, o estilo neoclássico toma conta do Brasil por volta do século XIX, através da influência dos franceses. Natal incluiu-se nesse contexto. Várias edificações importantes para a história potiguar representam as características desse estilo e exaltam a sutileza e a beleza de seus traços, no qual se encontram em boa conservação (MELO; SILVA FILHO, 2007).

A partir do século XIX, Natal realmente inicia seu desenvolvimento urbano e a cidade começa a crescer e a construir cada vez mais edifícios. Na ocasião, o estilo predominante dessas construções foi o ecletismo, de forma que o mesmo não possui traços ou características próprias, ele agrega propriedades de outros estilos distintos e os misturam de modo a ressaltar o melhor de cada um. Outras técnicas são retratadas nos patrimônios do centro histórico, mas esses são os principais e mais recorrentes, e ajudam a remontar a história e a memória da comunidade local e estabelecer uma ligação entre os acontecimentos do passado e a identificação dos potiguares com o seu legado (MELO; SILVA FILHO, 2007).

Os Quadros 1 e 2 apresentam alguns dos edifícios que se destacam nos bairros em estudo, apontando suas principais características e questões acerca da acessibilidade e das atividades desenvolvidas: 
Quadro 1: Edifícios do bairro da Cidade Alta que possuem potencial turístico.

Table 1: Building neighborhood of Uptown that have tourism potential.

\begin{tabular}{|c|c|c|c|}
\hline Edifício & Descrição & Acessibilidade & Atividades ofertadas \\
\hline Igreja do Galo & $\begin{array}{l}\text { Terceiro templo religioso da cidade. De } \\
\text { estilo barroco, possui um galo em sua torre } \\
\text { lateral como um de seus principais traços. } \\
\text { Engloba o convento de Santo Antônio e o } \\
\text { Museu de Arte Sacra }\end{array}$ & $\begin{array}{l}\text { Possui rampa na calça- } \\
\text { da, porém a entrada da } \\
\text { igreja não possui. }\end{array}$ & $\begin{array}{l}\text { Missa, exposição de } \\
\text { obras e objetos no Mu- } \\
\text { seu de Arte Sacra e } \\
\text { visita ao Convento de } \\
\text { Santo Antônio }\end{array}$ \\
\hline $\begin{array}{l}\text { Memorial Câmara } \\
\text { Cascudo }\end{array}$ & $\begin{array}{l}\text { Construído no final do século XIX para abri- } \\
\text { gar a Sede da Fazenda. Hoje, homenageia } \\
\text { o folclorista potiguar Luís da Câmara Cas- } \\
\text { cudo, e guarda grande acervo de seu traba- } \\
\text { lho }\end{array}$ & $\begin{array}{l}\text { Possui rampa na calça- } \\
\text { da, porém a entrada não } \\
\text { disponibiliza rampa }\end{array}$ & $\begin{array}{l}\text { Exposição de objetos } \\
\text { ligados ao folclore e à } \\
\text { cultura popular, além de } \\
\text { objetos pessoais e ho- } \\
\text { menagens a Câmara } \\
\text { Cascudo }\end{array}$ \\
\hline $\begin{array}{l}\text { Igreja de Nossa Se- } \\
\text { nhora da Apresenta- } \\
\text { ção }\end{array}$ & $\begin{array}{l}\text { Conhecida como antiga catedral. Primeiro } \\
\text { templo religioso construído na cidade, a } \\
\text { edificaçãa atual foi construída em cima da } \\
\text { antiga capelinha que havia ali, havendo } \\
\text { ainda ruínas da mesma dentro da igreja }\end{array}$ & $\begin{array}{l}\text { Possui rampa na calça- } \\
\text { da, porém a entrada da } \\
\text { igreja não possui }\end{array}$ & $\begin{array}{l}\text { Missa e visitação guiada } \\
\text { no período vespertino }\end{array}$ \\
\hline $\begin{array}{l}\text { Praça André de Albu- } \\
\text { querque }\end{array}$ & $\begin{array}{l}\text { Marco de início do desenvolvimento da } \\
\text { cidade. Ao seu redor foi construída a igreja } \\
\text { matriz e as construções mais importantes } \\
\text { da época, como Casa de Câmara e Cadeia } \\
\text { e Tesouraria da Fazenda. Algumas dessas } \\
\text { construções continuam preservadas }\end{array}$ & $\begin{array}{l}\text { Possui rampas na calça- } \\
\text { da }\end{array}$ & $\begin{array}{l}\text { Espaço público de lazer } \\
\text { da cidade, com ativida- } \\
\text { des culturais que acon- } \\
\text { tecem esporadicamente }\end{array}$ \\
\hline $\begin{array}{l}\text { Igreja de Nossa Se- } \\
\text { nhora do Rosário }\end{array}$ & $\begin{array}{l}\text { Segundo templo religioso construído em } \\
\text { Natal. Foi construída para que os negros } \\
\text { assistissem a missa separados dos brancos }\end{array}$ & $\begin{array}{l}\text { Possui vários degraus } \\
\text { em sua entrada }\end{array}$ & $\begin{array}{l}\text { Missa, incluindo uma } \\
\text { missa rezada em latim } \\
\text { uma vez por semana, } \\
\text { nos domingos pela ma- } \\
\text { nhã }\end{array}$ \\
\hline $\begin{array}{l}\text { Palácio Felipe Cama- } \\
\text { rão }\end{array}$ & $\begin{array}{l}\text { Prédio com predominância arquitetônica do } \\
\text { estilo eclético, foi inaugurado em } 1922 \text { e } \\
\text { abriga e é a sede do Governo Municipal de } \\
\text { Natal }\end{array}$ & $\begin{array}{l}\text { Possui vários degraus } \\
\text { em sua entrada }\end{array}$ & $\begin{array}{l}\text { Aberto ao público para } \\
\text { visitação do edifício em } \\
\text { horário comercial }\end{array}$ \\
\hline Palácio Potengi & $\begin{array}{l}\text { Construído em meados de } 1873 \text {, predomina } \\
\text { o estilo neoclássico. Sempre teve utilidade } \\
\text { pública, funcionando como Tesouraria Pro- } \\
\text { vincial, Repartição do Correio, Câmara Mu- } \\
\text { nicipal, Júri. Hoje é a Pinacoteca do Estado }\end{array}$ & $\begin{array}{l}\text { Possui rampa na calça- } \\
\text { da, porém a entrada } \\
\text { principal não possui }\end{array}$ & $\begin{array}{l}\text { Exposição de quadros e } \\
\text { apresentações culturais }\end{array}$ \\
\hline Capitania das Artes & $\begin{array}{l}\text { Concluído no final do século XIX, abrigou a } \\
\text { Capitania dos Portos até a década de 1970, } \\
\text { ficando posteriormente abandonado. Ape- } \\
\text { nas a fachada é restaurada }\end{array}$ & $\begin{array}{l}\text { Possui um degrau na } \\
\text { sua entrada principal, } \\
\text { porém, o acesso ao } \\
\text { prédio contém uma ram- } \\
\text { pa }\end{array}$ & $\begin{array}{l}\text { Galeria de arte e apre- } \\
\text { sentações culturais }\end{array}$ \\
\hline Solar Bela Vista & $\begin{array}{l}\text { Construído no início do século XX para ser } \\
\text { a residência de um rico coronel. Foi Tribunal } \\
\text { de Justiça e um luxuoso hotel. Funciona } \\
\text { como Centro de Cultura e Lazer do SESI }\end{array}$ & $\begin{array}{l}\text { Possui vários degraus } \\
\text { em sua entrada }\end{array}$ & Apresentações culturais \\
\hline Instituto Ludovicus & $\begin{array}{l}\text { Moradia do potiguar mais ilustre, o jornalis- } \\
\text { ta, escritor e folclorista Câmara Cascudo. } \\
\text { Criado em sua homenagem, abriga suas } \\
\text { obras e seus objetos pessoais }\end{array}$ & $\begin{array}{l}\text { Possui vários degraus } \\
\text { em sua entrada }\end{array}$ & $\begin{array}{l}\text { Exposição de objetos e } \\
\text { obras de Câmara Cas- } \\
\text { cudo }\end{array}$ \\
\hline
\end{tabular}

Fonte: Dados da pesquisa (2012).

Source: Survey data (2012). 
Quadro 2: Edifícios do bairro da Ribeira que possuem potencial turístico.

Table 2: Building the Ribeira district that have tourism potential.

\begin{tabular}{|c|c|c|c|}
\hline Edifício & Descrição & Acessibilidade & Atividades ofertadas \\
\hline $\begin{array}{l}\text { Museu de Cultura Popular } \\
\text { Djalma Maranhão }\end{array}$ & $\begin{array}{l}\text { Construído para ser o termi- } \\
\text { nal rodoviário em } 1963 \text {. Foi } \\
\text { restaurado e abriga o Mu- } \\
\text { seu de Cultura Popular } \\
\text { Djalma Maranhão }\end{array}$ & $\begin{array}{l}\text { Possui uma escadaria em } \\
\text { sua entrada }\end{array}$ & $\begin{array}{l}\text { Exposição de obras, obje- } \\
\text { tos e quadros que remetem } \\
\text { à cultura popular do RN }\end{array}$ \\
\hline Teatro Alberto Maranhão & $\begin{array}{l}\text { Concluído no início do sé- } \\
\text { culo XX, passou por várias } \\
\text { reformas. O estilo eclético } \\
\text { está presente em sua arqui- } \\
\text { tetura. }\end{array}$ & $\begin{array}{l}\text { Possui rampas de acesso } \\
\text { em sua entrada }\end{array}$ & $\begin{array}{l}\text { Apresentações teatrais } \mathrm{e} \\
\text { musicais }\end{array}$ \\
\hline Grande Hotel & $\begin{array}{l}\text { Foi o primeiro grande hotel } \\
\text { da cidade, construído na } \\
\text { década de } 1930 \text {. Hospedou } \\
\text { várias personalidades, in- } \\
\text { cluindo grande artistas e } \\
\text { militares durante a Segunn- } \\
\text { da Guerra Mundial }\end{array}$ & $\begin{array}{l}\text { Possui uma escadaria em } \\
\text { sua entrada }\end{array}$ & $\begin{array}{l}\text { No local, funcionam varas } \\
\text { do juizado cível }\end{array}$ \\
\hline Casa da Ribeira & $\begin{array}{l}\text { Construído na primeira } \\
\text { década do século XX, já foi } \\
\text { hospedaria, oficina de navi- } \\
\text { os, padaria e loja de materi- } \\
\text { al de construção. Atualmen- } \\
\text { te é um espaço cultura, } \\
\text { com teatro, café e sala de } \\
\text { exposições }\end{array}$ & $\begin{array}{l}\text { Possui rampa em sua en- } \\
\text { trada, porém, alguns locais } \\
\text { internos possui apenas uma } \\
\text { escadaria como acesso }\end{array}$ & $\begin{array}{l}\text { Apresentações teatrais e } \\
\text { musicais, sala de exposição } \\
\text { e biblioteca com livros de } \\
\text { arte e literatura em geral }\end{array}$ \\
\hline Beco da Quarentena & $\begin{array}{l}\text { Uma pequena via que era } \\
\text { frequentada por prostitutas } \\
\text { e marinheiros com doen- } \\
\text { ças. A polícia utilizava o } \\
\text { beco para acuar os bader- } \\
\text { neiros. }\end{array}$ & $\begin{array}{l}\text { Calçamento em paralepípe- } \\
\text { do, de difícil acesso para } \\
\text { cadeirantes }\end{array}$ & Espaço público \\
\hline $\begin{array}{l}\text { Antigo Palácio do Gover- } \\
\text { no }\end{array}$ & $\begin{array}{l}\text { Construído no século XIX, } \\
\text { foi uma das sedes do Go- } \\
\text { verno. Abrigou também um } \\
\text { dos bares mais famosos da } \\
\text { Ribeira. Foi restaurado e } \\
\text { atualmente é sede da Esco- } \\
\text { la de Dança do Teatro Al- } \\
\text { berto Maranhão }\end{array}$ & $\begin{array}{l}\text { Possui uma escadaria em } \\
\text { sua entrada }\end{array}$ & Aulas de dança \\
\hline Rua Chile & $\begin{array}{l}\text { Rua mais antiga da Ribeira, } \\
\text { abriga vários comércios e } \\
\text { armazéns, além de várias } \\
\text { fachadas preservadas. } \\
\text { Possui vários bares e casas } \\
\text { noturnas }\end{array}$ & $\begin{array}{l}\text { Calçamento em paralepípe- } \\
\text { do }\end{array}$ & $\begin{array}{l}\text { Espaço público, mensal- } \\
\text { mente ocorre apresenta- } \\
\text { ções culturais durante o } \\
\text { evento "Circuito Cultural da } \\
\text { Ribeira" }\end{array}$ \\
\hline
\end{tabular}

Fonte: Dados da pesquisa (2012).

Source: Survey data (2012).

É importante ressaltar que o patrimônio material edificado dos dois bairros contempla um número significativo de edifícios que possui potencial e podem ser trabaIhados em relação ao turismo cultural. Aqui, foram elencados apenas alguns deles, os quais foram escolhidos em função de sua atratividade e atividades desenvolvidas. 
A partir da evolução e do desenvolvimento que Natal sofreu e da preservação de alguns dos seus primeiros prédios e monumentos, pode-se remontar e contar a história dos primórdios da cidade, que é o legado do povo potiguar e é bastante diversificado e rico, no qual se tem muito potencial em desenvolver um roteiro para que outras pessoas também possam conhecer o Centro Histórico, despertando esse interesse não apenas dos turistas, mas também da população local.

\section{Propostas para o turismo cultural no Centro Histórico em estudo}

O turismo cultural é um segmento em desenvolvimento e uma prática bastante utilizada em vários destinos turísticos, inclusive em cidades brasileiras, como Ouro Preto e Salvador. Há também muitos outros sucessos com o segmento na Europa, por exemplo (FUNARI; JAIME, 2003). Apesar dos casos bem-sucedidos e da comprovação de que a cultura é capaz de atrair fluxos de turistas, Natal ainda não desenvolveu essa área e não atentou em demonstrar as possibilidades de atividades que existem em seu Centro Histórico.

Para trabalhar e desenvolver o segmento, é necessário que haja uma estrutura básica para a propagação desses elementos, além de quesitos como o acesso aos bairros da Cidade Alta e Ribeira. É importante que as pessoas possam locomover-se pelas ruas e ter a sinalização adequada, que auxilie no seu deslocamento. Além disso, também é interessante que sejam disponibilizadas informações a respeito do patrimônio, de modo que ao chegar a algum local, o visitante tenha a sua descrição básica e/ou alguém disponível para acompanhar a visita e explanar sobre o local e esclarecer todas as dúvidas recorrentes.

Nota-se também uma deficiência não apenas nas questões estruturais do centro histórico, mas um fator recorrente também é a questão da divulgação. Os atrativos principais de Natal são o sol e a praia, aspectos ligados às belezas naturais - não tirando o valor que esses elementos têm para a cidade - mas reconhecendo a importância que o centro histórico possui e o seu rico potencial que ainda não é explorado. Trata-se de aspectos amplamente promovidos, enquanto o segmento cultural é esquecido pelos empresários do trade turístico e até mesmo pela população, que não conhece o valor de sua história (MELO; MENEZES, 2010).

Os passeios tradicionalmente comercializados pelas agências de turismo é baseado em explanações e descrições do local, da maneira tradicional, como ocorre em vários locais. Mas o ideal é que essa apresentação seja feita de forma mais dinâmica e que interaja mais com os turistas. Para isso, é preciso pensar em estratégias que diferenciem o modo em que o roteiro é apresentado, propondo um aprendizado lúdico a respeito dos patrimônios.

Algumas atividades são apresentadas como sugestões para serem desenvolvidas nos espaços em estudo, a saber: na Praça André de Albuquerque - que inclui o marco zero da cidade do Natal - pode-se pensar na utilização de fotos e na explanação não apenas de fatos, mas também de curiosidades sobre o local, de forma que haverá uma comparação entre como a cidade era e o que ela tornou-se no decorrer do tempo, além de acrescentar histórias interessantes sobre o seu contexto. 
Outros recursos, além da questão do comparativo com as fotos, podem ser viabilizados. Por exemplo, é possível utilizar material multimídia que poderia mostrar, de forma breve e interativa, o centro histórico e algumas informações adicionais sobre o local visitado, no qual seria mostrado ao final do city tour e auxiliaria também na fixação das informações que foram passadas durante a visitação.

Ademais, outras propostas que poderiam ser utilizadas seriam a apresentação de danças folclóricas, reforçando a cultura potiguar e estimulando os artistas locais. Essa exibição poderia ser feita ao final de todo o percurso, onde os turistas visitariam a parte histórica da cidade e após apreciariam a manifestação artística da cidade. Essa apresentação poderia ser feita no Museu de Cultura Popular Djalma Maranhão (Figura 3), localizado na Praça Augusto Severo (Ribeira), local que possui um considerável acervo sobre os artistas populares potiguares e dispõe ainda de salas com telões para exibição de vídeos e um local para exposições. Ainda ali na praça, encontra-se também um outro elemento importante em termos históricos e arquitetônicos, o Teatro Alberto Maranhão (Figura 4).

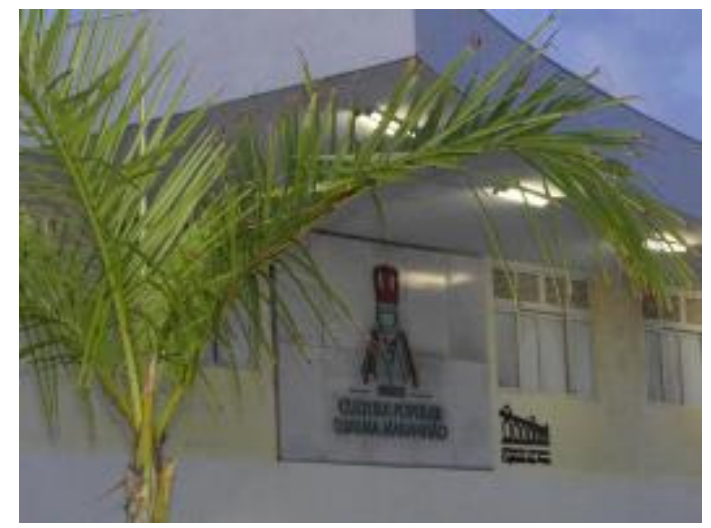

Figura 3: Museu de Cultura Popular.

Foto: Patrícia Amaral (2011).

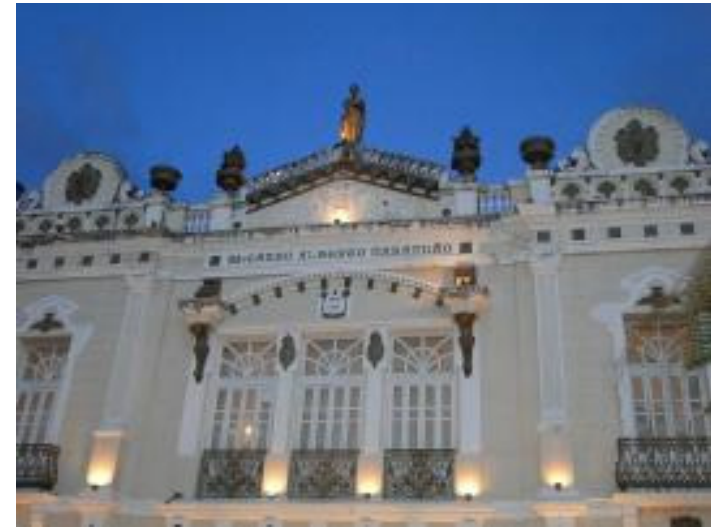

Figura 4: Teatro Alberto Maranhão. Foto: Patrícia Amaral (2011).

Todavia, para que seja implementado esse tipo de turismo, é primordial que a comunidade local esteja envolvida, não somente na questão econômica, quando pode comercializar seus produtos, mas também em outras atividades. É preciso haver uma identificação com o local e com a sua história. Pensando nesse viés, a realização de trabalhos de educação patrimonial é algo importante para que a comunidade também dele se aproprie, identificando-se e, assim, valorizando o mesmo, o que pode fazer com que os espaços sejam preservados e se tornem mais atrativos aos turistas. A partir desse reconhecimento, será possível demonstrar a outras pessoas os valores da cultura potiguar e a importância do centro histórico como objeto de memória na vida das pessoas e na formação da sua história, daí a importância da efetivação de projetos de educação patrimonial. 


\section{Conclusão}

O Centro Histórico de Natal é rico em relação ao seu patrimônio cultural, pois possui prédios com diferentes estilos arquitetônicos, construídos em distintas épocas. Eles são capazes de representar momentos históricos da cidade, fato ainda pouco explorado na perspectiva do turismo cultural. Os visitantes que vêm a Natal estão focados nas praias e belezas naturais da cidade e do seu entorno, e os aspectos culturais são pouco divulgados, não havendo também um grande interesse em promovê-lo por parte do trade turístico, e especialmente pelos restritos investimentos realizados pelo poder público.

Os edifícios localizados no centro histórico são inúmeros, ofertando algumas atividades aos seus visitantes. Contudo, há questões de infraestrutura que precisam ser revistas, como a questão da acessibilidade em diversos espaços, assim como a própria questão da sinalização interpretativa. É preciso, ainda, dinamizar os equipamentos, para que estejam efetivamente prontos para receber o público de turistas.

Mas esse não é o único problema encontrado nos bairros da Cidade Alta e da Ribeira, objeto do presente estudo. Deve ser levada em consideração também a falta de identificação das pessoas com os patrimônios e monumentos, de modo que a valorização deve vir primeiro da comunidade local e depois das pessoas que venham a visitá-lo, tendo-se, assim, uma questão mais ampla e abrangente. Aponta-se, assim, a importância da realização de trabalhos de educação patrimonial junto à comunidade local.

A atividade turística deve ser trabalhada no sentido de acrescentar e desenvolver o centro histórico, de modo que irá dinamizar a economia na região e estabelecer um intercâmbio cultural entre as pessoas, além de estabelecer uma utilização desses espaços culturais. $O$ aproveitamento dos espaços pode contribuir na preservação dos ambientes em uso e garantir que reparos sejam feitos para meIhorar as estruturas físicas e as condições de acesso ao objeto de estudo em questão.

A pesquisa foi feita no sentido de desenvolver uma discussão a respeito da utilização do centro histórico como atrativo turístico da cidade do Natal. É uma área carente em relação a pesquisas e estudos, mas há várias iniciativas que tentam propor formas de estimular e alavancar esse segmento, mas muito ainda precisa ser feito para que este espaço seja reconhecido e valorizado.

\section{Referências bibliográficas}

ABREU, R.; CHAGAS, M. (Org.). Memória e patrimônio: ensaios contemporâneos. 2. ed.Rio de Janeiro: Lamparina, 2009.

BARRETTO, M. Cultura e turismo: Discussões contemporâneas. Campinas, SP: Papirus 2007. - (Coleção Turismo) 
BARRETTO, M. Turismo e legado cultural: As possibilidades do planejamento. Campinas, SP: Papirus, 2000. - (Coleção Turismo)

CASCUDO, L.C. História da cidade do Natal. Natal (RN): RN Econômico, 3. ed 1999.

COSTA, F.R. Turismo e patrimônio cultural: interpretação e qualificação. São Paulo: Editora Senac São Paulo: Edições SESC SP, 2009.

DIAS, R. Turismo e patrimônio cultural: recursos que acompanham o crescimento das cidades. São Paulo: Saraiva, 2006.

FOSTER, G.M. As culturas tradicionais e o impacto da tecnologia. São Paulo: Fundo de Cultura, 1964.

FUNARI, P.P.; PINSKY, J. (orgs). Turismo e patrimônio cultural. São Paulo: Contexto, 2003. 3를 - (Coleção Turismo Contexto)

KOSTER, H. Viagens ao Nordeste do Brasil. Recife: Secretaria de Educação e Cultura, 1978 (Coleção Pernambucana, vol. XVII).

MARTINS, C. (Org.). Patrimônio cultural: da memória ao sentido do lugar. São Paulo: Roca, 2006.

MELO, M.A.W.S.; MENEZES, S.V.A. Um novo olhar para o corredor cultural: proposta de modelos de city tours para a cidade do Natal/RN. Trabalho de Conclusão do Curso de Turismo. Universidade Potiguar. Natal, 2010.

MENDES, C. Centro histórico de Natal. Iphan: Natal, 2007.

MINISTÉRIO DO TURISMO. Pesquisa de hábitos de consumo do turismo brasileiro. 2009. Disponível em:

http://www.dadosefatos.turismo.gov.br/export/sites/default/dadosefatos/ demanda turistica/pesquisa habitos/

Download pesquisa habitos/13.11.09 Pesquisa Hxbitos 2009.pdf Acesso em 25 jan 2012.

RICHARDS, G. Nuevos caminos para El turismo cultural? Barcelona: Diputación de Barcelona / Association for Tourism And Leisure Education - Atlas/ Observatorio Interarts, 2005, disponível em http://www.diba.es . Acesso em 25 jan 2012.

RODRIGUES, W.C. Metodologia científica. Disponível em:

http://professor.ucg.br/siteDocente/admin/arquivosUpload/3922/material/Willian\% 20Costa\%20Rodrigues metodologia cientifica.pdf . Acesso em 30 jan 2012. 
Patrícia Daliany Araújo do Amaral: Instituto Federal de Educação, Ciência e Tecnologia do Rio Grande do Norte, Natal, RN, Brasil.

Email: pdaliany@hotmail.com

Link para o currículo Lattes: http://lattes.cnpq.br/6276197262789514

Isabella Ludimilla Barbosa do Nascimento: Instituto Federal de Educação, Ciência e Tecnologia do Rio Grande do Norte, Natal, RN, Brasil.

Email: isabella_ludimilla@hotmail.com

Link para o currículo Lattes: http://lattes.cnpq.br/0935409945176042

Fábio Henrique da Silva Gomes: Instituto Federal de Educação, Ciência e Tecnologia do Rio Grande do Norte, Natal, RN, Brasil.

Email: faabio.henrique@hotmail.com

Link para o currículo Lattes: http://lattes.cnpq.br/5222976964204691

Data de submissão: 30 de maio de 2012

Data de recebimento de correções: 02 de julho de 2013

Data do aceite: 04 de julho de 2013

Avaliado anonimamente 